До 100-річчя

Національної академії наук України 
НАЦІОНАЛЬНА АКАДЕМІЯ НАУК УКРАЇНИ УКРАЇНСЬКИЙ МОВНО-ІНФОРМАЦІЙНИЙ ФОНД

\section{ЛІНГВІСТИЧНО-ІНФОРМАЦІЙНІ СТУДІї}

\section{ПРАЦІ \\ УКРАЇНСЬКОГО МОВНО-ІНФОРМАЦЙННОГО ФОНДУ НАН УКРАЇНИ}

\section{У П’ЯТИ ТОМАХ}

Дослідження 1991-2018 років

За загальною редакцією $B$. А. Широкова

КИїВ 2018 
НАЦІОНАЛЬНА АКАДЕМІЯ НАУК УКРАЇНИ УКРАЇНСЬКИЙ МОВНО-ІНФОРМАЦІЙНИЙ ФОНД

TOM III

\section{ТЛУМАЧНА ЛЕКСИКОГРАФІЯ} КНИГА 3

\section{ДИНАМІКА ЛЕКСИКО- СЕМАНТИЧНОГО СКЛАДУ СЛОВНИКА УКРАЇНСЬКОЇ МОВИ У ДВАДЦЯТИ ТОМАХ}




\author{
Рекомендовано до друку вченою радою \\ Українського мовно-інформачійного фонду НАН Украӥни \\ (протокол № 9 від 23 жовтня 2018 р.) \\ Рецензенти: \\ академік НАН України $O . B$. Палагін, \\ член-кореспондент НАН України $A$. О. Загнітко \\ Автори третьої книги третього тому: \\ В. А. Широков, Л. О. Симоненко, Н. В. Стратулат, Л. М. Томіленко, Л. Л. Шевченко
}

Лінгвістично-інформаційні студії : Праці Українського мовно-інформаційного фонду НАН України : у 5 т. Т. 3 : Тлумачна лексикографія. Кн. 3 : Динаміка лексико-семантичного складу Словника української мови у двадцяти томах / В. А. Широков та ін. Київ : Український мовно-інформаційний фонд НАН України, 2018. 230 с.

Третя книга «Динаміка лексико-семантичного складу Словника української мови у двадцяти томах» третього тому «Тлумачна лексикографія» п'ятитомної монографії «Лінгвістичноінформаційні студії» містить аналіз активних процесів розвитку лексичного складу української мови 3 80-х років XX ст. до сьогодення: загальновживаної, біблійної й термінологічної лексики, представленої у тлумачних словниках української мови в 11-ти й 20-ти томах (СУМ-11 і СУМ-20).

Висвітлено теоретичні проблеми дослідження розвитку лексико-семантичної системи української літературної мови, визначено роль зовнішніх і внутрішніх чинників, які впливають на динамічний характер словникового складу мови й зумовлюють виникнення якісних та кількісних лінгвальних змін.

Проведено дослідження загальновживаної лексики: основних інноваційних входжень до СУМ-20 - дериваційних та семантичних неологізмів. Застосування словотворчого аналізу дало змогу описати дериваційні утворення, дослідити основні способи творення, виявити продуктивні словотвірні типи, окреслити найважливіші тематичні групи новацій. На основі компонентного аналізу досліджено семантичні неологізми, охарактеризовано семантичний процес метафоризації, що зумовив появу нових значень, встановлено головні твірні моделі, які лягли в їх основу, а також сфери функціонування інноваційних одиниць в українській літературній мові.

Описано лексику і фразеологію Святого Письма, яка знайшла системне представлення в СУМ-20 через залучення нових реєстрових слів, заміну дефініцій слів та усталених словосполучень, розвиток семантичної структури лексем, значне розширення ілюстративної бази.

Здійснено комплексний аналіз термінології, яка $є$ суттєвою частиною реєстру кожного великого тлумачного словника. Ї̈̈ дослідження в СУМ-11 та СУМ-20 дозволяє простежити еволюцію основного термінологічного складу української мови. Опис словотвірних моделей дав змогу дослідити способи творення доданих термінологічних одиниць, виявити їхні продуктивні типи й основні значення. На основі семного аналізу простежено процес термінологізації загальновживаних слів. Аналіз нової термінологічної лексики, введеної до реєстру Словника української мови у 20-ти томах, дозволив виявити найактивніші лексикодериваційні мовні процеси, дослідження яких сприяє формуванню уявлення про роль та місце термінів у мові.

ISBN 978-966-02-8683-2

ISBN 978-966-02-8688-7 (Т. 3. Кн. 3)
(C) Український мовно-інформаційний фонд НАН України, 2018

(C) В. А. Широков, Л. О. Симоненко, Н. В. Стратулат, Л. М. Томіленко, Л. Л. Шевченко, 2018 
ВСТУП

Р ОЗ ДіЛ 17. ФОРМУВАННЯ ЛЕКСИКО-СЕМАНТИЧНОГО СКЛАДУ ЗАГАЛЬНОВЖИВАНОЇ ЛЕКСИКИ У СЛОВНИКУ УКРАЇНСЬКОЇ МОВИ В 20-ТИ ТОМАХ

17.1. Теоретичні засади вивчення змін у лексико-семантичній системі української мови

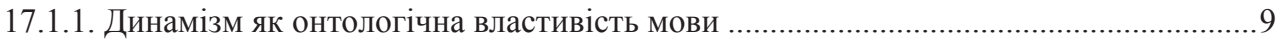

17.1.2. Чинники розвитку лексичної системи.

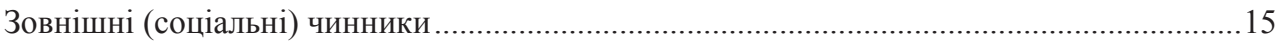

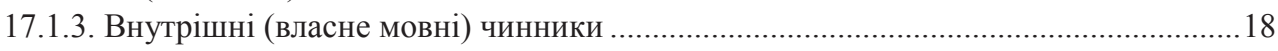

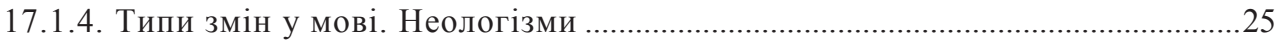

17.1.5. Загальномовний словник як найповніше представлення

мовного матеріалу сучасної української мови .........................................................29

17.2. Дериваційні неологізми в лексичній системі сучасної

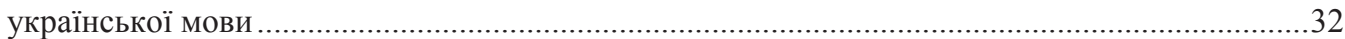

17.2.1. Словотворення як основний процес розширення словникового складу

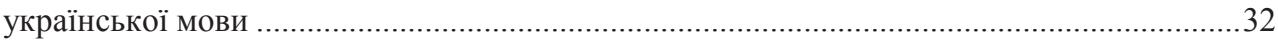

17.2.2. Іменникові інновації у складі лексики української мови.....................................39

17.2.2.1. Іменникові деривати, утворені суфіксальним способом ...................................39

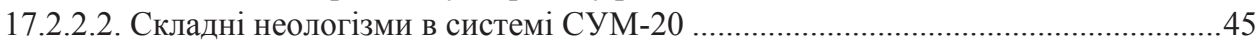

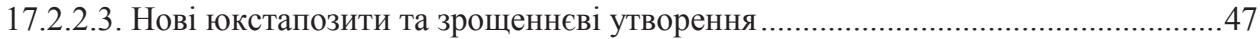

17.2.2.4. Нові абревіатури в словниковому складі української мови ............................52

17.2.2.5. Інноваційні композиційні утворення в лексичній системі СУМ-20................59

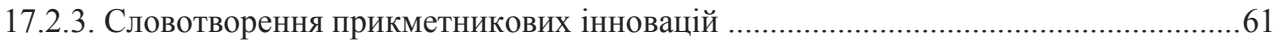

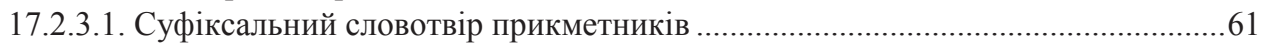

17.2.3.2. Префіксально-суфіксальний словотвір прикметників ....................................66

17.2.3.3. Префіксальний спосіб творення прикметників ................................................ 71

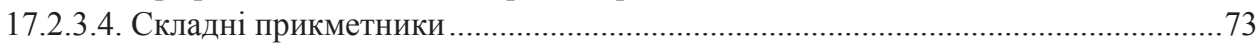

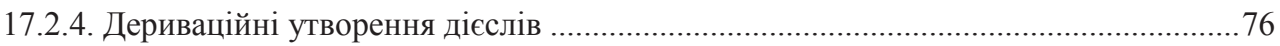

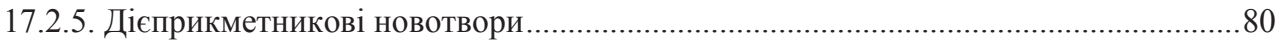

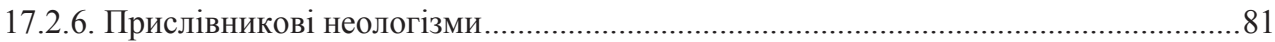

17.3. Семантичні неологізми в лексичній системі української мови ......................................8 84

17.3.1. Семантичні процеси як один із шляхів збагачення лексики

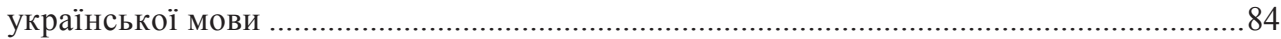

17.3.2. Процес метафоризації як одне із основних джерел

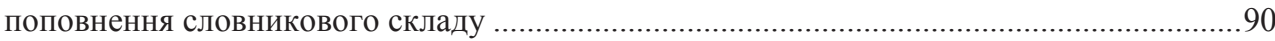

17.4. Лексика і фразеологія Святого Письма ....................................................................... 113 


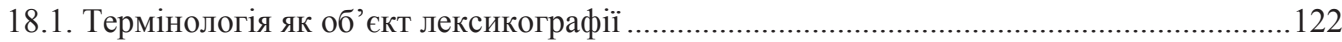

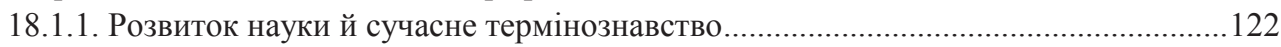

18.1.2. Галузева лексика у великих загальномовних тлумачних словниках ....................124

18.1.3. Питання про частиномовну належність термінів фахової лексики.

Терміни-прислівники в тлумачній лексикографії ...................................................132

18.2. Термінологічна лексика в Словниках української мови в 11 -ти та 20-ти томах............135

18.2.1. Інструментальний комплекс «Словник української мови»

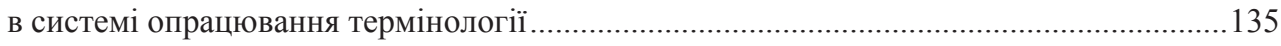

18.2.2. Класифікація галузевої термінології. Тематичні групи слів ................................138

18.2.3. Класифікація термінології Словника української мови в 11-ти томах та розширення іiї складу в Словнику української мови у 20-ти томах ...........................140

18.2.3.1. Терміни нових галузей знань

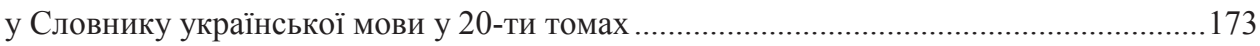

18.3. Шляхи й способи поповнення термінології

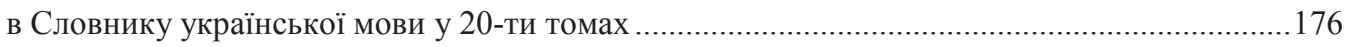

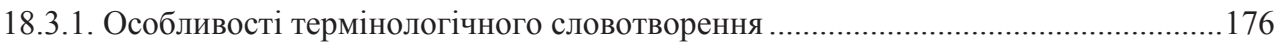

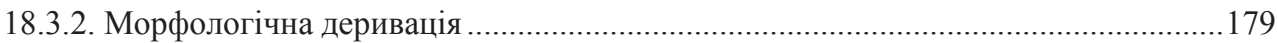

18.3.2.1. Основні способи творення термінів-іменників .......................................... 181

18.3.2.1.1. Суфіксальний спосіб творення термінів-іменників .................................... 181

18.3.2.1.2. Префіксальний спосіб творення термінів-іменників .................................. 185

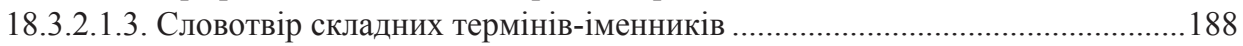

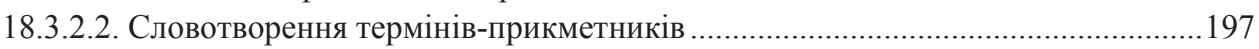

18.3.2.2.1. Суфіксальний спосіб творення термінів-прикметників ..............................197

18.3.2.2.2. Префіксальний спосіб творення термінів-прикметників ...........................199

18.3.2.2.3. Префіксально-суфіксальний спосіб творення

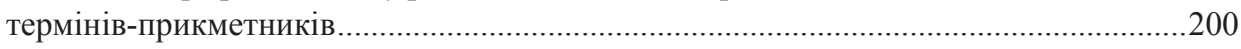

18.3.2.2.4. Словотвір складних термінів-прикметників..............................................2202

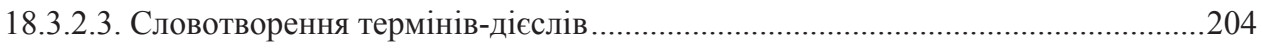

18.3.2.3.1. Суфіксальний спосіб творення термінів-дієслів .....................................204

18.3.2.3.2. Префіксальний спосіб творення термінів-дієслів .....................................206

18.3.2.3.3. Постфіксальний словотвір термінів-дієслів ..........................................207

18.3.2.3.4. Словотворення дієприкметників-термінів............................................208

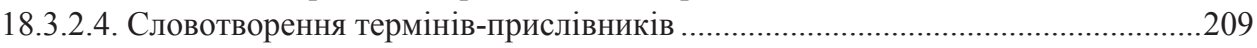

18.3.2.4.1. Суфіксальний словотвір термінів-прислівників .........................................209

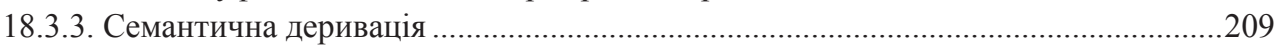

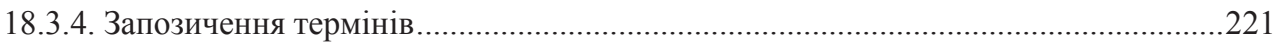

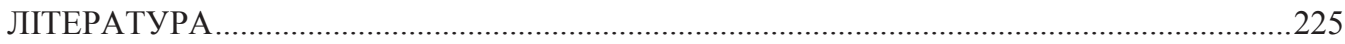




\section{ВСТУП}

Зміни в різних сферах життя соціуму: суспільно-політичній, науковотехнічній, духовній, культурній та ін. під впливом нових суспільних умов породжують нові об’єкти називання і формують потребу в неологізмах. У свою чергу, мова як системно-структурне утворення характеризується такою внутрішньою організацією (системні міжрівневі взаємозв'язки, власний словотворчий потенціал, стилістичні зміни, існування мовних антиномій тощо), яка зумовлює розвиток мовної системи.

Найвиразніше відображає мовну динаміку лексико-семантичний рівень. Словниковий склад є найбільш чутливим до всіх зовнішніх факторів впливу, на ньому активно відбивається дія внутрішніх законів розвитку мови. Лексичний склад активно реагує на зміни в суспільстві та відображає різні види перетворень у ньому. Дослідження розвитку лексики сучасної української мови десятиліть - кінця XX - початку XXI століть - засвідчило значне входження до лексичної системи значного масиву нових слів, що відбиває процес пристосування мовної системи до нових потреб комунікації у зв’язку зі стрімким розвитком науки та техніки, економічними перетвореннями, виникненням нових суспільних відносин, інформаційною революцією, глобалізаційними процесами і т. ін. Із цим пов'язане входження раніше не відомих слів та словосполучень до словникового складу мови, спричинене необхідністю найменування значної кількості нових предметів, явищ та понять. Ці процеси знайшли відображення у словотворчих неологізмах, в різноманітних семантичних змінах різних груп лексики, в освоєнні запозичених слів. Усе це досить актуальні теми, розробка яких $\epsilon$ значимою в колі інших проблем сучасного мовознавства.

Найбільш повне зібрання лексики української мови на сьогодні представляє СУМ-20 - понад 200 тис. реєстрових словникових одиниць. Зіставлення СУМ-20 та СУМ-11 надає можливості проаналізувати інноваційні 
процеси в лексико-семантичній системі української мови, виявити тенденції та шляхи іï розвитку, встановити причини виникнення та характер цих змін. Матеріал СУМ-20 дозволяє з найбільшою повнотою розкрити питання про те, наскільки глибокі зміни відбулися в лексиці досліджуваного періоду.

Звернення до інноваційних явищ передбачає перш за все аналіз загальновживаної та термінологічної лексики, де вони проходять особливо інтенсивно. Комунікативний простір, який покриває ця лексика, знаходиться в стані постійних змін, які спричинені різними соціальними перетвореннями та внутрішньою організацією мови, що, в свою чергу, породжують нові номінативні одиниці, сприяють оновленню лексичного складу. Окремим аспектом вивчення стала біблійна лексика, яка отримала широке входження до реєстру нових слів і значень, демонструючи значне розширення меж існування та відношень біблійної мікросистеми Словника. 


\section{РОздІЛ 17}

\section{ФОРМУВАННЯ ЛЕКСИКО-СЕМАНТИЧНОГО СКЛАДУ ЗАГАЛЬНОВЖИВАНОЇ ЛЕКСИКИ У СЛОВНИКУ УКРАЇНСЬКОЇ МОВИ В 20-ТИ ТОМАХ}

\section{1. Теоретичні засади вивчення змін у лексико-семантичній системі української мови}

\subsection{1. Динамізм як онтологічна властивість мови}

Однією з найважливіших передумов функціонування мови є її власти вість рухатися та перебувати в стані перманентних змін, де на кожному етапі іiі існування розвиваються ті засоби й способи вираження, ті тенденції, які найбільше відповідають новим соціально-культурним завданням та умовам мовленнєвої комунікації.

Вивчення питань мовної еволюції завжди було в колі уваги мовознавців. Зокрема, мінливість мовної системи досліджували І. В. Арнольд, Л. О. Кудрявцева, Е. В. Кузнєцова, М. В. Панов, Ю. С. Сорокін, Г. А. Уфімцева, Ф. П. Філін, М. М. Шанський, Д. М. Шмельов та ін. Низка досліджень, в яких розкриваються різні аспекти динамічного характеру мови, представлена також в роботах учених-україністів. В. М. Русанівський, О. С. Мельничук, М. П. Кочерган, Ж. П. Соколовська, О. О. Тараненко та інші дослідники висвітлювали теоретичні питання розвитку та вдосконалення української мови; В. В. Жайворонок, М. А. Жовтобрюх, Л. А. Лисиченко, С. С. Лук'яненко, Д. В. Мазурик, Л. Б. Мартинова, О. Г. Муромцева, Л. М. Полюга, І. А. Самойлова, О. А. Стишов та ін. займалися дослідженнями лексико-семантичних змін. Оскільки мова знаходиться в стані постійного розвитку, зазначені проблеми залишаються актуальними 3-поміж інших важливих завдань, що стоять перед сучасним мовознавством.

Динамізм мови як її онтологічна ознака безпосередньо пов'язаний із іiі сутністю. Лінгвісти визнають, що «...мова - це динамічна система, для якої 
здатність до розвитку є природним способом її соціального існування. Розвиток мови протікає під знаком їі постійного удосконалення та збагачення функціональних можливостей» ${ }^{1}$. Мова розвивається завдяки своїй природі, своєму призначенню - функціонувати в суспільстві, забезпечуючи його потреби в спілкуванні. Вона влаштована таким чином, що ii існування, динамічні процеси, які відбуваються в ній, перебувають у прямій залежності від людського фактора. Вільгельм фон Гумбольдт в своїй роботі «Избранные труды по языкознанию» писав, що мова закладена в самій природі людини і необхідна для розвитку іï духовних сил і формування світогляду, вона «являє собою постійно поновлюючу роботу духу, яка направлена на те, щоб зробити артикуляційний звук придатним для вираження думки» ${ }^{2}$. Мова $\epsilon$ не результатом діяльності, а самою діяльністю, тому, за словами вченого, «Мову слід розглядати не як мертвий продукт (Erzeugtes), а як творчий процес (Erzeugung)» ${ }^{3}$. Наголошуючи на постійній мовотворчій силі, дослідник висловлює думку про те, що кожна мова полягає в акті іiі реального породження: «Дійсна матерія мови - це, з одного боку, звук взагалі, а з іншого сукупність чуттєвих вражень і безпосередніх рухів духу, які передують утворенню поняття, що здійснюється за допомогою мови» ${ }^{4}$.

Мовна система як спосіб відображення мінливості життя суспільства зазнає постійних змін, і пї розвиток зумовлений безперервністю цих змін. Висловлюючись про неперервність, повсякчасність процесу розвитку мови як неодмінної умови іiі функціонування, О.С. Мельничук зазначав: «...як постійний процес суспільної діяльності мова розвивається протягом усієї історії людства» ${ }^{5}$. Еволюція мови - багатство словника, функціонально-

${ }^{1}$ Кузнецова Э. Г. Лексикология русского языка: учеб. [пособие для филол. фак. ун-тов] / [2-е изд., испр. и доп.]. М. : Высш. шк., 1989. С. 153.

${ }^{2}$ Гумбольдт В. фон. Избранные труды по языкознанию / Пер. с нем. Г. В. Рамишвили. М. : Прогресс, 1984. С. 70.

${ }^{3}$ Гумбольдт В. фон. Избранные труды по языкознанию / Пер. с нем. Г. В. Рамишвили. М. : Прогресс, 1984. С. 69.

${ }^{4}$ Гумбольдт В. фон. Избранные труды по языкознанию / Пер. с нем. Г. В. Рамишвили. М. : Прогресс, 1984. С. 73.

\footnotetext{
${ }^{5}$ Мельничук О. С. Розвиток мови як реальної системи. Мовознавство. 1981. № 2. С. 6.
} 
стилістична спеціалізація мовних засобів, семантична диференціація граматичних форм та ін. - тісно пов’язана 3 історією та культурою народу, створюється на протязі століть народом, що говорить цією мовою. Кожне нове покоління вносить дещо нове не тільки в суспільний лад, у філософське та естетичне осмислення дійсності, але і в засоби вираження цього осмислення засобами мови. Перш за все такими засобами стають нові слова, нові значення слів, нові оцінки того значення, що закладене у відомих словах. «Кожне наступне покоління має багатшу мову, ніж попереднє» 6 .

Отже, саме постійний розвиток мови, процеси мовних модифікацій, зумовлені суспільними змінами, забезпечують функціонування мови в соціумі. Але зміни в мові як реальній системі не порушують тенденції до її стійкості, не руйнують іiі внутрішньої єдності та цілісності. Поряд 3 тенденцією до змінності, мінливості діє також інша сторона мови - тяжіння до стабільності. Мовна стабільність закладена в системній організації мови,

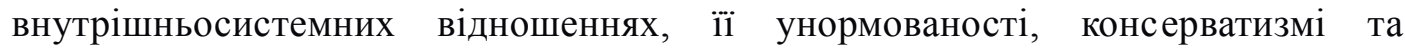
традиційності. Так, функціонування мови як системи, що постійно спирається на традицію, обгрунтував у своїх працях Ф. де Соссюр. На його думку, поряд із змінністю, розвитком мови слід говорити про те, що «...за будь-якої доби, - як би ми не заглиблювалися в минуле, - мова завжди виступає як спадщина попередньої епохи» ${ }^{7}$. Мовознавець у своїй роботі наголошував на тому, що спадкоємність як властивість мовної системи заперечує будь-яку можливість загальних раптових змін в мові, що будь-який теперішній стан мови завжди $є$ продуктом історичних чинників, які й пояснюють, чому мовний знак незмінний, тобто чому він чинить опір усякій спробі довільної заміни. За словами вченого, «...усяке суспільство знає i завжди знало мову лише як успадкований від попередніх поколінь продукт, що має сприйматися лише таким, який він є» ${ }^{8}$.

\footnotetext{
${ }^{6}$ Русанівський В. М. Життя слова / В. М. Русанівський, С. Я. Єрмоленко. К. : Вища шк. при КДУ, 1978. С. 127.

${ }^{7}$ Соссюр Ф. де. Курс загальної лінгвістики. К. : Основи, 1998. С. 93.

${ }^{8}$ Соссюр Ф. де. Курс загальної лінгвістики. К. : Основи, 1998. С. 94.
} 
Таким чином, сталість дозволяє існувати кожній мові як цілісній системі, забезпечуючи внутрішній взаємозв'язок і взаємодію іiі елементів та рівнів. Стабільність є однією 3 підвалин збалансованості мовної системи, що допомагає утримуватися їй у певних заданих межах. Так, інноваційні входження та модифікації в лексичному складі мови не порушують іiі порядку та єдності. Н. Ю. Шведова переконана, що «...внутрішня організація класу слів в цілому стійко зберігається протягом тривалого часу і не змінюється ні під впливом процесів формального чи семантичного словотворення, ні під впливом внутрішньогрупових і міжгрупових переміщень, ні під натиском їі сторонніх входжень. Усі такі процеси не руйнують лексичної системи: вони відбуваються всередині їі» ${ }^{9}$. Відносна стійкість і визначеність лексики забезпечує можливість збереження й передавання знань про світ, обумовлюючи саму можливість взаєморозуміння між носіями тієї ж мови, але одночасно не є перешкодою для мовного відображення безмежної кількості ситуацій і постійної зміни як самого світу, так і людських знань про нього.

Мова - одна із найважливіших складових суспільства, його інтелектуального та духовного життя. Як засіб спілкування соціуму, вона спрямована на відтворення надбань людства, забезпечуючи його життєдіяльність. I саме стабільність, що закладена в мовній системі, сприяє відтворенню накопиченого досвіду в наступних поколіннях. «Мова постійно розвивається і разом з тим як засіб зв'язку між різними генераціями лишається незмінною... мова попереднього покоління лишається для наступного цілком зрозумілою, бо вона втрачає менше, ніж набуває» ${ }^{10}$. 3 іншого боку, обслуговуючи суспільство, мова відображає актуальну дійсність. Кожен період розвитку мови залишає свій слід на лексичному складі мови, відтворюючи сучасне життя народу. Змінюються реалії та умови життя, розширюються комунікативні сфери, збагачується система знань - все це є факторами, що стимулюють постійні зміни мовної системи та збільшення їі можливостей.

\footnotetext{
${ }^{9}$ Шведова Н. Ю. Предисловие к двадцать первому изданию // С. И. Ожегов. Словарь русского языка. 21 изд. М., 1991. С. 7.

${ }^{10}$ Плотников Б. А. О форме и содержании в языке. Минск : Высш. шк., 1989. С. 47.
} 
Отже, можна констатувати, що мова як функціональна система «...одночасно поєднує в собі дві протилежні риси: незмінність і змінність, статистичність і динамічність» ${ }^{11}$. Названі особливості мови $є$ тими онтологічними ознаками, які забезпечують iï функціонування, що дозволяє їй на певному етапі існування - синхронному зрізі - перебувати в стані динамічної рівноваги. Мова під впливом сучасного життя суспільства зазнає в низці аспектів суттєвих кількісних та якісних перетворень, але не піддається якимнебудь суттєвим змінам, зберігаючи системну і структурну цілісність, а також внутрішню стійкість та ідентичність.

Еволюційні процеси в мові охоплюють своєю дією мовну систему в

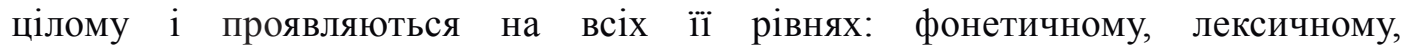
морфологічному та синтаксичному. Проте найбільше мовні перетворення спостерігаються на лексичному рівні, що характеризується найвищим ступенем екстралінгвістичної детермінованості, для якого характерні такі риси, як рухливість, відкритість, гнучкість і проникливість. Збагачення лексикону один iз важливих факторів розвитку мови, свідчення його динамічного характеру. Російський мовознавець Ю. С. Сорокін, вивчаючи динаміку лексичного складу, зазначає, що «Словник - сфера в мові найбільш “прониклива”. Лексика, на відміну від інших мовних систем, мало проникливих і більш замкнутих (напр., системи фонематичної або граматичної), безперечно, більш широка, складна, гнучка й рухлива» ${ }^{12}$. Це обумовлено тим, що лексичний склад мови безпосередньо звернений до позамовної дійсності й пов’язаний 3 нею. Він є найбільш чутливим до змін навколишніх реалій, активно відображає різні види перетворень у соціумі, знаходячи реалізацію в постійному двоєдиному процесі архаїзації та оновленні словникового складу: «...при значній стійкості й традиційності він безперервно реагує на найменші зміни в природі та суспільстві: із змінами в позамовній дійсності пов’язане виникнення

${ }^{11}$ Семчинський С. В. Загальне мовознавство. [2-ге вид.]. К. : АТ «ОКО», 1996. С. 320.

${ }^{12}$ Сорокин Ю. С. Развитие словарного состава русского литературного языка. 30-90 годы XIX века. М.; Л. : Наука, 1965. С. 14. 
нових, зникнення, вихід на периферію лексичної системи застарілих слів і значень» ${ }^{13}$.

Сприйнятливість мови до позамовних впливів зумовлена самим характером складових її одиниць, їх основною суспільною функцією: інновації в мові з'являються у зв’язку з «...потребами вираження якихось нових змістів або чіткого позначення вже відомих об'єктів» ${ }^{14}$. Відбиття змін у мові стосуються перш за все номінативного потенціалу нового слова, його здатності фіксувати фрагмент реального світу. При цьому збагачення словника відбувається різними шляхами і перш за все за допомогою словотворчих можливостей мовної системи. Номінативна функція деривації полягає у творенні мовних одиниць, які забезпечують іменування нових фактів дійсності та формування понять про них. Крім того, у ході мовної еволюції використовується і змістово-смисловий потенціал, закладений в самому словниковому складі: переосмислення значення слова, нарощення нової семантики, стилістична переоцінка слів - усе це, поряд з появою запозичень, значно розширює і збагачує словник мови, посилює його потенцію.

Поповнення словника перш за все свідчить про розширення можливостей мови в плані виконання нею комунікативних функцій. Лексико-семантичні новоутворення, викликані потребами номінації сучасних реалій, $\epsilon$ для позначення тих змін, що відбуваються в суспільстві: «...новотвори певного історичного періоду несуть у собі в стислому вигляді досить широку інформацію про особливості економічного, політичного, культурного життя своєї епохи, в них, як у зародку, виявляються ті мовні тенденції, які розвинуться в майбутньому. I чим важливіша епоха для певного суспільства, чим більш насичена вона життєво важливими подіями, тим активніше реагує мова творенням нових слів, які забезпечують і вимоги суспільства, і вимоги мови, що розвивається» ${ }^{15}$. При цьому кожен період розвитку мови характеризується своїм словниковим складом. Основні зміни, обумовлені

13 Лисиченко Л. А. Лексикологія сучасної української мови. Семантична структура слова. Харків: Харк. ун-т, 1977. С. 8.

${ }^{14}$ Мельничук О. С. Розвиток мови як реальної системи. Мовознавство. 1981. № 2. С. 30-31.

15 Муромцева О. Г. Розвиток лексики української літературної мови в другій половині XIX - на поч. XX ст. Харків : Вища шк., 1985. С. 11. 
зовнішніми чинниками, відбуваються саме в тих тематичних сферах, які $\epsilon$ комунікативно актуальними і відображають провідні тенденції у розвитку суспільства.

Зміни в лексиці, рух вперед у часі під впливом реальної дійсності, людського мислення, свідомості, означає розвиток мови в цілому. Б. А. Плотников зазначав: «Еволюція всього плану змісту мови означає по суті, або в крайньому випадку в значній мірі, еволюцію іï словникового складу, оскільки саме в ньому відкладаються і фіксуються нововведення, зрушення i перетворення, що намітилися в поняттях і уявленнях носія мови» ${ }^{16}$. Створення різними шляхами нових лексичних одиниць, їхній рух із однієї стилістичної сфери в іншу, зникнення із мови та перехід 3 активного запасу в пасивний i навпаки багатьох слів та їх значень відображають динамічні процеси лексики сучасної української мови.

\subsection{2. Чинники розвитку лексичної системи. Зовнішні (соціальні) чинники}

У дослідженні розвитку словникового складу особливу роль відіграє встановлення факторів, що зумовлюють мовну еволюцію. Як відомо, динаміка мови викликана позамовними (соціальними), і внутрішньомовними чинниками. Ці фактори взаємозалежні й перебувають у постійній взаємодії та взаємозв'язку, впливаючи не тільки на розвиток мови, а й на саме їі існування [В. К. Журавльов, Е. В. Кузнєцова, Л. О. Кудрявцева, Л. А. Лисиченко, О. С. Мельничук, В. М Русанівський, Ю. С. Сорокін, Ф. П. Філін та ін.].

Сучасне мовознавство, виходячи 3 положення про мову як суспільне явище, про їі соціальну природу, зміни в мові пов’язує зі змінами в суспільстві : «Мова у відомому смислі служить барометром суспільного розвитку, оскільки в ній відображаються основні коливання, зміни в житті суспільства» ${ }^{17}$. Вплив соціальних факторів на мову найбільш повно, різносторонньо і концентровано

\footnotetext{
${ }^{16}$ Плотников Б. А. О форме и содержании в языке. Минск : Высш. шк., 1989. С. 189.

17 Дешериев Ю. Д. Проблема функционального развития языков и задачи социолингвистики // Язык и общество / [под ред. Ф. П. Филина]. М. : Наука, 1968. С. 55-56.
} 
відбувається через посередництво, розширення та розвиток ії суспільної ролі. Суспільство, прагнучи через мовні засоби реалізувати свої комунікативні потреби, шукає найбільш раціональні засоби найменування. Як підкреслюють дослідники, «...для більш адекватного відображення, відтворення й закріплення нових ідей і понять мова взагалі і лексика зокрема змушені перебудовуватися, поповнюватися новими компонентами» ${ }^{18}$.

Будь-які зміни, що виникають у суспільстві, стають реальністю для суспільного творення, відображаючись, проявляючись у мові. Немає жодної суспільної сфери, куди б не проникала мова. Основні функції мови і визначають iii спрямованість на виконання соціальних замовлень суспільства, приводячи в рух механізм мовних змін і регулюючи динаміку лексичної системи. На цьому факторі наголошував в своїх працях В. М. Русанівський: «Функції мови активно впливають на ії структуру і багато в чому визначають напрям мовного розвитку... Мова - явище соціальне, безпосередньо залежне від тих різних суспільних обставин, у яких перебуває її носій - народ» 19 .

Модифікації в лексиці відбуваються безперервно і в той же час нерівномірно, менш чи більш швидко, реагуючи на ситуації в суспільстві. Існують періоди, для яких характерні значні перетворення в навколишній дійсності. До таких періодів належить i наш час, що характеризується інтенсивним розвитком суспільного життя у всіх його проявах, що в свою чергу привело до значних змін у змісті та системі мови.

На сучасному етапі розвитку лексики української мови, спричиненому новими соціально-культурними завданнями і умовами мовленнєвої комунікації, можна виділити такі зовнішні чинники, актуальність яких, безперечно, відображена в комунікативному просторі мови.

Соціальні перетворення в країні, створення нової державності, яка поновому впливає на комунікативні сфери, процеси демократизації суспільства,

18 Левицький А. С. Актуальні проблеми розвитку неології (на матеріалі англійської мови). Вісник Житомирського держ. ун-ту імені Івана Франка. Житомир: Ред.-вид. від Житомирського держ. ун-ту імені Івана Франка. Вип. 23. 2005. С. 16-22.

${ }^{19}$ Русанівський В. М. Мова і суспільний процес // Мова і процеси суспільного розвитку [ред. В.М. Русанівський]. К. : Наук. думка, 1980. С. 19. 
стрімка науково-технічна революція, зміна економічної та політичної ситуації в країні та ін. сприяють виникненню великої кількості нових явищ, понять, об’єктів, породжують нові форми суспільних і підприємницьких відносин між людьми. Лавиноподібний потік інформації та нових знань у сучасних умовах розвитку суспільства також є потужним чинником стимуляції появи нових словесних одиниць.

До зовнішніх позамовних чинників, що сприяють мовному розвитку та вдосконаленню, відносяться також міжмовні контакти, які обумовлюють процес запозичення слів та виразів іншомовного походження, що збагачує словниковий склад мови. Підсилена взаємодія мов при зростаючій ролі культурних та економічних зв'язків між країнами приводить не тільки до засвоєння слів іншомовного походження та їх елементів. Іншомовні одиниці, мігруючи, пристосовуються до особливостей системи мови, яка їх запозичила, внаслідок чого відбувається входження не тільки іноземних лексем в мову-позичальник, а також різних словотворчих елементів, здатних утворювати нові слова. Процес переходу елементів однієї мови до іншої сприяє проникненню та утворенню інноваційних одиниць, різноманітним змінам в лексиці, розширенню словотворчих можливостей національної мови.

Дослідниками окремо виділяються також психологічні фактори, які породжують такі явища, як табу, евфемізми, прагнення до гіперболізації, іронії, бажання висловлювати суб'єктивні почуття тощо ${ }^{20}$. Не менш важливими причинами, що зумовлюють мовну динаміку, є зміна соціального складу носія мови, зміна суспільних поглядів, мовних смаків, звичок, зміна мовної свідомості носіїв мови, суспільного оточення, в якому мова існує тощо. Реакція лексико-семантичної системи на ці процеси ще раз підтверджує їі основне призначення та функцію - комунікацію, i свідчить про iï суспільну мотивованість.

Крім того, значна роль у розвитку лексичного складу належить окремим носіям мови. Спочатку окремий індивідум створює яку-небудь інновацію - нове

${ }^{20}$ Брагина А. А. Неологизмы в русском языке. М. : Просвещение, 1973. С. 97. 
слово, форму, словосполучення, синтаксичну конструкцію. У подальшому ця інновація оцінюється, приймається або відхиляється іншими членами суспільства $^{21}$. Усе нове, потребуючи вербалізації, створює передумови розширення i збагачення лексичної системи: «Процес народження нової номінації відзначається закономірною двоступеневістю - суб'єктивацією нового найменування у мовній свідомості колективу, а згодом об'єктивацією його в словнику, галузевому чи загальномовному. Внаслідок цього те, що фіксує мовна свідомість, фіксується водночас і мовною пам'яттю, стаючи потім мовною традицією. Тим самим збагачується зміст мови, тобто їі лексичний склад» $^{22}$. На сьогодні спостерігається значна активізація мовної поведінки членів суспільства, зростання індивідуального творчого начала у процесі мовної діяльності користувачів. Під впливом соціальних змін змінилася й мовна компетенція членів комунікативного середовища, розширилося коло представників мовотворення.

Природно, що зазначені екстралінгвістичні фактори не могли не відобразитися на номінативному фонді сучасної української мови. У зв'язку зі зміною суспільної ситуації відбувається закономірне оновлення мови. Лексикосемантичні інновації, що виникли в цей період, є номінативним наслідком змін в соціумі. Таким чином, розвиток i функціонування мови великою мірою зумовлені станом суспільства. Зовнішні, соціальні чинники є дуже потужними, вони є тими необхідними умовами, що спонукають їі перебувати в постійному русі, спричиняють різні перетворення і модифікації в мовній системі.

\subsection{3. Внутрішні (власне мовні) чинники}

Поповнення лексичного фонду новоутвореннями пов'язане також 3 факторами внутрішнього характеру. Мова як системно-структурне утворення змінюється та розвивається за власними законами, при цьому задіюються іiі

${ }^{21}$ Языковая номинация. Виды наименований / [отв. ред.: Б. А. Серебренников, А. А. Уфимцева]. М. : Наука, 1977. С. 153.

22 Жайворонок В. В. Лексична підсистема мови і значення мовних одиниць. Мовознавство. 1999. № 6. С. 35. 
внутрішні ресурси та можливості, які є потужним потенціалом мовних змін. У самій мовній системі закладені тенденції та процеси, які $є$ чинниками лінгвальної еволюції. Їх значимість неодноразово підкреслювали лінгвісти, зокрема, Д. М. Шмельов писав: «Розвиток мови зумовлений самою її природою, тобто призначенням, структурою складових одиниць» ${ }^{23}$. Із огляду на внутрішньолінгвістичні характеристики мови значимим в цьому відношенні $€$ факт існування притаманного мові системного характеру. Сукупність мовних явищ являє собою систему, що грунтується на взаємозалежності їі елементів: «Реальна система конкретної мови являє собою невичерпну за складністю i різноманітністю впорядковану сукупність підсистем різних планів і рівнів ${ }^{24}$.

Знак як одиниця мови не існує сам по собі і не розглядається ізольовано, а лише у взаємодії з іншими знаками, тобто в системі. Слова являють собою систему, i, як інші одиниці мови, вони зіставляються й протиставляються між собою за цілим рядом ознак, перебувають у певній взаємодії. Тому при лінгвістичному дослідженні словникового складу слід обов'язково враховувати системний характер мови в смислі, докладно проаналізованому в першому томі нашого багатотомника.

Системні характеристики лексичної системи втілені, насамперед, у закономірностях словотворення та наявному словотворчому арсеналі засобів. «Слово самим актом свого народження пов'язане 3 іншими словами. Словотвірні зв’язки дають слову життя і визначають його фізіономію, дають йому “внутрішню форму”. Вони прив’язують слово до певного граматичного, структурного розряду» ${ }^{25}$. Система українського словотвору організована в такий спосіб, що при будь-яких суспільних змінах потужний дериваційний матеріал засобів (як власний, так і запозичений), а також наявні твірні основи стають підгрунтям для виникнення нових лексем, що, в свою чергу, приводить

${ }^{23}$ Шмелев Д. Н. О некоторых тенденциях развития современной русской лексики // Развитие лексики современного русского языка [под ред. Е. А. Земской и Д. Н. Шмелева]. М.: Наука, 1965. С. 7.

${ }^{24}$ Мельничук О. С. Розвиток мови як реальної системи. Мовознавство. 1981. № 2. С. 22.

${ }^{25}$ Сорокин Ю. С. Развитие словарного состава русского литературного языка. 30-90 годы XIX века. М.; Л. : Наука, 1965. С. 14. 
до розширення та збагачення українського лексикону. Описуючи системну організацію та потенційну можливість мови змінюватися, О. С. Мельничук відзначав: «Навіть постійно відкритий для входження нових елементів рівень мовної системи - словник - поповнюється новими словами меншою мірою шляхом запозичення 3 інших мовних систем, ніж шляхом словотворення (включаючи калькування), тобто використання наявних у мові лексичних елементів i закріплених у ній правил творення нових слів» ${ }^{26}$. Цим самим забезпечується дальше посилення внутрішньої єдності системи, взаємодії та взаємозв’язку іiі компонентів і рівнів. Отже, функціонування словотвору як підсистеми (у взаємодії та взаємозв’язках іiі елементів), тяжіння до словотворчої аналогії $\epsilon$ тими внутрішніми аспектами, що зумовлюють розвиток та вдосконалення мовної системи.

Лексичний рівень є окремою підсистемою мови. Це означає, що всі зміни в лексиконі: поява та зникення нових слів та значень, активізація та вихід на периферію лексичних одиниць, стилістична трансформація і т. ін., спричиняють зміни лексичної та синтаксичної сполучуваності слів, а отже, зміни в самій лексико-семантичній системі. Описуючи системність лексики, Л. А. Лисиченко констатує: «Системність лексичного складу сучасної мови виявляється в усіх їі елементах: в організації їі лексико-тематичних груп, у структурі багатозначного слова, у наявності антонімічних i синонімічних $і$ т. п. зв’язків» ${ }^{27}$. Ця взаємозалежність елементів в лексичній системі та в системі мови взагалі $€$ характерною ознакою і рушієм механізму мовної динаміки. Завдяки системним відношенням елементів всередині лексики, зовнішні фактори, що торкаються тих чи інших ділянок мови, мають вплив і на інші іiі ділянки. Мова взагалі, лексика зокрема, перебудовуються, диференціюються і уточнюються для того, щоб більш адекватно відобразити, відтворити, закріпити нові ідеї, явища i поняття у відповідних словах і виразах.

${ }^{26}$ Мельничук О.С. Розвиток мови як суспільне явище i як предмет сучасного мовознавства. Мовознавство. 1991. № 3. С. 9.

27 Лисиченко Л. А. Лексикологія сучасної української мови. Семантична структура слова. Харків: Харк. ун-т, 1977. С. 8. 
Таким чином, у результаті дії загального принципу системності мова є таким витвором, в якому завжди присутня «ідея доцільності та придатності» ${ }^{28}$. Вона ж поширюється і на нові слова, тому кожна нова лексична одиниця, «...що 3'являється в лексиці мови, не може бути новоутворенням, що створене поза правилами та законами словотворення, системою і граматичним складом мови. Створене без дотримання названого, слово буде мертвонародженим словом, непотрібним та безглуздим набором звуків» ${ }^{29}$. Тобто все нове, що вносять суспільні умови, які змінилися, в значення і вживання слів, підпорядковане внутрішній організації лексико-семантичної системи та її законам.

Важливим внутрішнім стимулом розвитку лексичного складу мови, особливо у період значного розширення інформаційного пласту, є діючий у мові «закон мовної економії» (О. Ссперсен), або «закон збереження мовних зусиль» (А. Мартіне). Його дія виявляється у тому, що в процесі використання мови відбувається відбір найбільш раціональних та містких для цілей спілкування мовних засобів. Розширення словника української мови на основі прояву цього внутрішньомовного фактора є закономірним процесом, що досить активно діє в мовній системі. В результаті цього з’являються новоутворені складні слова i серед них - композити, абревіатури, юкстапозити, зрощення, які є зручним та ефективним засобом номінації.

Зазначений внутрішній стимул знаходить своє вираження також у заміні словосполучень, що носять, як правило, характер стійких мовних номінацій, однослівними найменуваннями як більш економними. Неологізми, що виникли в результаті дії закону економії мовних зусиль, як правило, виступають вторинними найменуваннями, а іноді стають єдиним засобом називання певного поняття.

Серед внутрішньомовних чинників лінгвістичного розвитку слід згадати ще ряд інших, які становлять значний теоретичний та практичний інтерес. Динамічна сутність мовної системи підпорядкована основному закону

${ }^{28}$ Будагов Р. А. Человек и его язык. М.: Изд-во Моск. ун-та, 1976. С. 285.

29 Шанский Н. М. Лексикология современного русского языка: пособ. для студ. пед. интов [2-е изд.]. М. : Просвещение, 1972. С. 163. 
діалектики: в мові існує своєрідна боротьба протилежностей, що спричиняє лінгвальні зміни та визначає саморозвиток мови. Про це в своїх роботах неодноразово писали вчені, які досліджували лінгвальні зміни [I. В. Арнольд, C. Й. Карцевський, Л. О. Кудрявцева, Е.В.Кузнєцова, О. Г. Муромцева, М. В. Панов, Ю. С. Сорокін, Ф. П. Філін, Д. М. Шмельов та ін.]. Ці протилежності, властиві мові, називаються мовними антиноміями. Вони зводяться до суперечностей між потребами спілкування i мовними можливостями. У мовній системі, як і в природі та суспільстві, діє один 3 основних законів діалектики: єдність і боротьба протилежностей, i, власне, ці антиномії значною мірою сприяють еволюції мови.

Ідея розвитку та вдосконалення мови через подолання «діалектичних протиріч» виражена у таких антиноміях: 1) антиномія мовця і слухача; 2) антиномія узусу і можливостей мовної системи; 3) антиномія коду і тексту; 4) антиномія двох функцій мови: інформаційної та експресивної; 5) антиномія, обумовлена асиметричністю мовного знака. Останнім двом вчені надають особливо важливого значення [Е. Сепір ${ }^{30}$, Ф. П. Філін ${ }^{31}$, Д. М. Шмельов ${ }^{32}$ ]. Тому на розкритті механізму їх дії в мовній системі ми зупинимося детальніше.

Антиномію двох функцій мови можна характеризувати як протиріччя між прагненням до регулярності одиниць, з одного боку, та протилежну їй - до їх експресивного виділення - 3 іншого. Інформаційна функція мови сприяє регулярності, однотипності одиниць; експресивна, навпаки, підтримує їх нестандартність, актуалізацію серед ряду інших, а також ідіоматичність в широкому розумінні слова.

Ці дві тенденції складно взаємодіють на різних рівнях мовної системи, причому їх дія стикається з іншими рушійними силами, значення яких зростає разом із закріпленням у свідомості мовця уявлення про мовну норму, мовний

${ }^{30}$ Сепир Э. Язык. Введение в изучение речи / Пер. с англ. А. М. Сухотина. М.-Л. : Соцекгиз, 1934. 223 с.

${ }^{31}$ Филин Ф. П. Истоки и судьбы русского литературного язика. М.: Наука, 1981. 326 с.

${ }^{32}$ Шмелев Д. Н. О некоторых тенденциях развития современной русской лексики // Развитие лексики современного русского языка [под ред. Е. А. Земской и Д. Н. Шмелева]. М.: Наука, 1965. 134 с. 
стандарт. «Ці сили, сили літературної традиції та “зразка” літературної мови перешкоджають багатьом експресивним зміщенням у мові. I вони ж утримують в літературній мові цілу низку нерегулярних утворень, від яких давно звільнилося менш зв'язане традицією протиріччя» ${ }^{33}$.

Важливим стимулом розвитку мови $є$ також антиномія, зумовлена асиметричністю мовного знака. Асиметричність полягає в тому, що у структурі мовного знака те, що позначає, та позначуване знаходяться в стані перманентного конфлікту: означувач прагне отримати нові значення, а означуване - нові засоби свого вираження. Таке спостереження над природою мовного знака подає, описує й обгрунтовує С. Й. Карцевський: «Означувач (звукове) та означуване (функція) постійно ковзає по “похилій площині реальності”. Кожне “виходить за межі”, визначені для нього партнером: означувач прагне набути нових функцій, крім своєї власної, означуване прагне знайти інші способи вираження, крім свого знака. Вони асиметричні: спарені, знаходяться в стані нестійкої рівноваги. Завдяки цьому асиметричному дуалізму структури знаків мовна система отримує стимул для розвитку: “адекватна” позиція знака безперервно переміщується внаслідок пристосування до потреб конкретної ситуації» ${ }^{34}$.

Мовні антиномії відіграють значну роль у динаміці мовної системи: вирішення кожної антиномії стимулює появу нових протилежностей, нових протиріч. Кожне вирішення будь-якої з вищеназваних протилежностей породжує нові зіткнення, нові протиріччя в мові (в принципі такого ж порядку) i, отже, «...їх остаточне повне вирішення, на думку дослідників, є неможливим» ${ }^{35}$. Це свідчить про динамічну природу мовної системи, про постійний її розвиток, про потенційну готовність мови до змін. Характер змін, зумовлений внутрішніми

${ }^{33}$ Широков В. А. Феноменологія лексикографічних систем. К. : Наук. думка, 2004. С. 16.

${ }^{34}$ Карцевский С. И. Об ассиметрическом дуализме лингвистического знака // Звегинцев В. А. История языкознания XIX-XX веков в очерках и извлечениях. М.: Учпедгиз, 1965. Ч. 2. С. 87.

35 Лексика современного русского литературного языка / Под ред. М. В. Панова. М. : Наука, 1968. С. 24. 
суперечностями, є важливою рушійною силою саморозвитку мови, постійним стимулом її еволюції.

Отже, наявність внутрішніх універсальних законів організації мовної системи, мовних антиномій виливається в такі внутрішні закони її розвитку, які забезпечують можливість ii збагачення, функціонального удосконалення, закріплюючи інноваційні виникнення як органічні елементи системи мови.

Природний рух у мові зумовлений складною взаємодією всіх чинників, i соціальних, i лінгвістичних, зазнаючи в цій взаємодії як кількісних, так i якісних змін. Дія внутрішніх і зовнішніх факторів відбувається одночасно. Російський мовознавець В. В. Виноградов 3 цього приводу наголошував: «Не слід думати, що закони розвитку мови, які витікають із їі суспільної функції, i закони, що витікають із структури мови, - це різні, взаємно не пов'язані закономірності ніби різних планів функціонування мови. Насправді вони взаємообумовлені і нерозривні» ${ }^{36}$.

Процеси, що проходять всередині лексичної підсистеми мови і спрямовані на розвиток i удосконалення системи значень, $є$ залежними від зовнішніх стимулів, тобто від потреби в найменуваннях нових суспільних явищ та понять. Останні приводять в дію мовний механізм, що спрямований на те, щоб дати реалії, явищу чи поняттю зручне для сучасного стану мовної системи позначення, відповідне тим чи іншим тенденціям ii сучасного розвитку. Н. С. Валгіна так характеризує загальний механізм мовної динаміки: «Взаємодія зовнішніх і внутрішніх факторів - головний закон в розвитку мови» ${ }^{37}$.

Таким чином, зовнішні фактори стимулюють внутрішньомовні, вони зумовлюють появу нових слів, але ці інновації утворені мовою за їі законами і 3 ii матеріалу. «Життя мови, в тому ж числі їі лексичної підсистеми, полягає у відповідній перебудові у зв’язку зі змінами в світі реалій: різними шляхами, під

${ }^{36}$ Виноградов В. В. Русский язык. Грамматическое изучение о слове. М. : Высш. шк., 1972. С. 33.

${ }^{37}$ Валгина Н. С. Активные процессы в современном русском языке: учеб. пособие [для студентов вузов]. М., 2003. С. 43. 
впливом різних тенденцій вона все більше пристосовується до потреб епохи, удосконалюється як складний інструмент людського спілкування» 38 .

Отже, динамічний характер мовної системи, на чому неодноразово наголошують мовознавці, зумовлений як зовнішніми, так і внутрішніми чинниками. Взаємодія цих стимулів мовного розвитку сприяє збагаченню номінативного фонду, розширенню меж його функціонування. Взаємообумовленість та нерозривний зв’язок зовнішніх i внутрішніх закономірностей динаміки мови є тим механізмом, що спонукає лексикосемантичну систему до різного роду перетворень, забезпечує їі існування, а також визначає специфіку розвитку та вдосконалення словникового складу.

\subsubsection{Tuпи змін у мові. Неологізми}

Одним із ключових понять при дослідженні сучасних змін у лексичному складі мови є поняття неологізму. Термін «неологізм» вживається при різних підходах до вивчення мови принаймні в двох окремих значеннях i, отже, є знаком для вираження щонайменше двох різних понять, які збігаються лише частково. Перше поняття, що передається терміном неологізм, має стилістичний характер і поширюється на всі слова або словесні значення, які відрізняються від звичних слів або звичайних словесних значень своєю новизною і пов'язаною з цим незвичністю. При такому підході до неологізмів відносять ті слова, які не втратили для носіїв мови стилістичної новизни. Друге поняття, позначуване терміном «неологізм», має суто хронологічний характер і поширюється на всі нові явища в галузі лексики протягом певного відрізка часу. Тут ми використовуємо поняття «хронологічні (відносні) неологізми», дане в праці В. Т. Коломієць «Розвиток лексики слов’янських мов у післявоєнний період» $^{39}$. Це лексичні одиниці, що є новими у Словнику української мови в 20-

${ }^{38}$ Волков С. С. Неологизмы и внутренние стимулы языкового развития / С. С. Волков, Е. В. Сенько // Новые слова и словари новых слов: сб. статей [отв. ред. Н.З. Котелова]. Л. : Наука, 1982. С. 56.

${ }^{39}$ Коломієць В. Т. Розвиток лексики слов'янських мов у післявоєнний період. К. : Наук. думка, 1973. С. 9. 
ти томах порівняно зі Словником української мови в 11-ти томах. Тобто до них відносяться слова, які виникли в період між створенням цих двох словників, або які не були зафіксовані в СУМ-11.

Поява нових мовних одиниць, постійні зміни в області лексики, що ведуть до збагачення і урізноманітнення словникового складу, відбуваються за рахунок різних процесів. Інновації, обумовлені «...потребами вираження якихось нових змістів або чіткішого позначення вже відомих об’єктів думки» ${ }^{40}$, з’являються в мові на базі вже існуючих словесних знаків і як власне дериваційні утворення, i як результат появи у наявних у мові слів нових значень, збагачення словника відбувається також за рахунок запозичень. У зв’язку з цим у сучасному мовознавстві розрізняють дериваційні, семантичні та лексичні неологізми.

Дериваційні (або словотворчі) неологізми - це лексичні одиниці, що утворилися на основі власних ресурсів мови за допомогою засобів словотворення. При цьому слід зауважити, що утворення нових слів шляхом деривації відіграє ключову роль у поповненні та розширенні словникового складу української мови, визначає основний напрям розвитку лексики, оскільки саме дериваційні новотвори були й залишаються основним джерелом розширення мовного діапазону словника [О. А. Земська, Н. З. Котєлова, А. В. Мамрак, О. Г. Муромцева, Ю. С. Сорокін, О. А. Стишов, Ф. П. Філін, М. М. Шанський та ін.]. Як пишуть дослідники про роль у розвитку лексичної системи словотворчого потенціалу, «...виконати завдання, яке ставить перед мовою суспільство, вона може лише шляхом утворення нових слів зі свого власного будівельного матеріалу, коли використовуються всі існуючі, досить різноманітні словотворчі засоби. Звідси видно, яке велике значення має в тій чи іншій мові словотворення: саме воно дозволяє мові мати відповідний розвитку суспільства словниковий склад» ${ }^{41}$.

Спираючись на власний словотвірний матеріал, а також запозичений 3 інших мов, українська дериваційна система має великий потенціал для

\footnotetext{
${ }^{40}$ Мельничук О. С. Розвиток мови як реальної системи. Мовознавство. 1981. № 2. С. 30-31.

${ }^{41}$ Шанский Н. М. Очерки по русскому словообразованию и лексикологии. М. : ГУППИ, 1954.
} C. 131 . 
утворення нових лексичних одиниць. Мова як системно-структурне утворення організована в такий спосіб, що «...в самій будові мови закладено великі можливості оновлення мовних засобів. Зокрема, кількість реальних слів завжди в багато разів менша тих можливостей, які закладені в інвентарі морфем, що використовуються для утворення слів. Система словотворення завжди перебуває в стані “бойової готовності” до породження нових слів, як тільки 3’явиться потреба в таких словах» ${ }^{42}$.

Виявом динамічних процесів у лексиці $є$ не тільки зростання словника української мови завдяки дериваційним утворенням. Розширення його меж відбувається також за рахунок значеннєвих модифікацій мовних одиниць. Різні семантичні процеси, які ведуть до розвитку у слів нових значень, відіграють важливу роль у розвитку та формуванні лексико-семантичної системи мови. Збагачення мовного складу відбувається завдяки процесу значеннєвих зсувів зміни семантики ряду відомих лексичних одиниць, тобто за рахунок семантичних неологізмів. Серед таких одиниць виділяють два різновиди: 1) слова, що повністю змінюють своє значення, втрачаючи всі властиві їм раніше; 2) слова, у семантичній структурі яких виникає один чи більше лексико-семантичних варіантів при збереженні всіх інших. Тобто суть семантичних неологізмів полягає в тому, що за допомогою наявних в мові слів дістають позначення нові поняття та реалії через розширення їх значення (вторинна номінація).

До вивчення питання семантичної еволюції зверталися багато дослідників: Р. О. Будагов, Л. А. Лисиченко, О. Г. Муромцева, Ж. П. Соколовська, Ю. С. Сорокін, Ф. П. Філін, Д. М. Шмельов та ін. На сучасному етапі розвитку української мови семантичні інновації стали об'єктом вивчення таких лінгвістів, як М. П. Кочерган, Л. О. Кудрявцева, Д. В. Мазурик, І. А. Самойлова, О. А. Стишов, О. О. Тараненко та ін.

Семантичні зміни в структурі слів є відгуком на потреби мовної практики, наслідком тих процесів, які відбуваються в різних сферах життя суспільства.

${ }^{42}$ Кузнецова Э. Г. Лексикология русского языка: учеб. пособие для филол. фак. ун-тов [2-е изд., испр. и доп.]. М. : Высш. шк., 1989. С. 155. 
Утворення семантичних неологізмів розвивається в напрямках збагачення смислових структур слів, розвитку різних переносних значень, пов’язаних iз формуванням різних сфер лексики, семантичної спеціалізації слів, уточнення та диференціації їх значень, пошуків позначень, які мають емоційне, експресивне забарвлення тощо.

Ще одну групу інновацій становлять лексичні неологізми, або запозичення. Міжмовні контакти, політичні, торгово-економічні, культурні стосунки 3 іншими країнами сприяють проникненню до української лексики слів іншомовного походження, які, в свою чергу, приводять до збагачення лексичного арсеналу української мови новими лексико-семантичними одиницями. Характер запозичень, особливості їх функціонування в мові визначаються тими специфічними мовними рисами i тенденціями, які характерні для досліджуваного періоду розвитку лексичного складу української мови. Слід відзначити, що лексика цього типу в досліджуваному матеріалі становить порівняно невелику кількість інновацій. Але саме запозичення є тим інструментом, що дає потужний імпульс лінгвальним модифікаціям, які $\epsilon$ матеріалом для творення нових слів за допомогою існуючих у мові словотворчих засобів. Мовна система має таку властивість, що як тільки туди проникають запозичення, вона адаптує їх до своєї системи, реагуючи на них таким чином, що вони, як правило, обростають формантами, утворюючи словотворчі гнізда, які через мовну практику закріплюються в словниковому арсеналі мови.

Дослідження різних процесів у лексико-семантичній системі передбачає врахування iii поділу на групи, які відображають відношення між мовною та позамовною дійсністю. У мові, де всі значення слів певним чином організовані та структуровані, такі відношення моделюють мікросистеми в структурі лексичного складу. Дослідники наголошують на важливості і доцільності вивчення словникового складу в плані його розмежування за лексикосемантичними групами: «Уся семантична система мовної картини світу така ж складна, як і сам світ, що в ній відбивається. Охопити їі одразу в цілісності неможливо, тому при вивченні семантичної системи мови і мовної картини 
світу в них виділяються певні фрагменти, семантичні відрізки, які охоплюють групи значень, що відрізняються широтою мовного матеріалу, глибиною семантичного членування, типами зв'язків між значеннями і т. ін.» ${ }^{43}$. У зв’ язку 3 цим в роботі при аналізі лексики зверталася увага на формування лексикосемантичних груп неологізмів, які виконують певну номінативну, пізнавальну, експресивно-емоційну функції. При такому підході лексичний склад мови в тлумачному словнику одержує системний опис, який полягає у виявленні i репрезентації зв’язків і відношень слова з іншими словами у межах лексикосемантичних груп. Таким чином розкриваються такі типологічні особливості досліджуваного матеріалу, які дозволяють спрогнозувати актуальні для лексичного складу мови шляхи та тенденції розвитку.

\subsection{5. Загальномовний словник як найповніше представлення мовного матеріалу сучасної української мови}

Укладання й видання словників - суспільно необхідна діяльність, важливий складник прогресу людства. Нині дуже багато лексикографічних праць, різних за обсягом та призначенням. Надзвичайно цінними й необхідними для кожної мови $€$, безперечно, словники тлумачного типу.

Сучасні тлумачні словники засвідчують рівень розвитку нації, науки, культури, виробничих відносин тощо. Високо оцінюючи роль та значення фундаментальних лексиконів, В. А. Широков наголошує на тому, що «...великі словники, звичайно, є взірцевими лексикографічними об'єктами, створеними колективами висококваліфікованих фахівців. Вони $є$ яскравими зразками лінгвістичної думки певного історичного періоду і несуть велику кількість явно і неявно виражених рефлексій 3 тією чи іншою епохою, у них «вкарбовано» історичну пам’ять народу та його мовну свідомість у певний період» ${ }^{44}$. Крім того, тлумачні лексикографічні праці - джерело «...величезного інформаційного та культурного ресурсу...», їх, «...на відміну від енциклопедій, ... спрямовано на маніфестацію передусім лінгвістичних даних, за допомогою яких лексичні

\footnotetext{
43 Лисиченко Л. А. Лексико-семантична система української мови. Харків, 1997. С. 140.

${ }^{44}$ Широков В. А. Комп’ютерна лексикографія. К.: Наук. думка, 2011. С. 5.
} 
одиниці вписуються в систему мови на всіх їі рівнях - i формальних, і змістових. Тому не випадково, що саме багатотомні словники тлумачного типу вважаються найвищими досягненнями кожної національної лексикографії, а там, де їх створено, вони фактично набувають статусу національного надбання» ${ }^{45}$.

Тлумачні словники подають усю складність лексико-семантичної системи на всіх їі рівнях, репрезентують усі типи й сфери вживання лексики та містять багато іншої інформації: «..дані про нормативне написання, особливості наголошування, основні граматичні характеристики, стилістичні властивості, контексти вживання, а також фразеологізми й інші семантико-синтаксичні структури, до складу яких входить дане слово. Таким чином, у тлумачних словниках представлена максимальна кількість лінгвістичних параметрів, що можуть лексикографуватися, тому вони стають основою для створення аспектних (однопараметричних) лексикографічних праць i проведення різнопланових лінгвістичних досліджень» ${ }^{46}$.

Інноваційні входження до лексико-семантичної системи української мови найбільш повно відображені в лексикографічній базі даних Словника української мови в 20-ти томах, яку створено в Українському мовноінформаційному фонді НАН України із використанням нової комп’ютерної технології лексикографування за участю науковців Національної академії наук України та викладачів вищих навчальних закладів у межах програми «Словники України».

Оскільки завдання нового тлумачного Словника - показати сучасний стан лексичного складу української літературної мови і представити з необхідною повнотою ㄲï лексику, то саме ця лексикографічна праця найповніше i найгрунтовніше відображає функціонування та розвиток мови на сучасному етапі іiі розвитку. Дослідники, наголошуючи на ролі тлумачних словників, зазначають, що в основу цього типу словників покладена «...єдина (реальна) мовна свідомість певного людського колективу в певний момент часу» ${ }^{47}$.

\footnotetext{
${ }^{45}$ Широков В. А. Феноменологія лексикографічних систем. К.: Наук. думка, 2004. С. 93-94.

${ }^{46}$ Там само. С. 94.

${ }^{47}$ Широков В. А. Феноменологія лексикографічних систем. К.: Наук. думка, 2004. С. 90.
} 
Підкреслюючи роль Словника у відображенні лексики як постійно діючої рухливої системи мови, Ф. П. Сороколєтов писав: «Перевидання великих тлумачних словників національної мови мають неоціненне значення для історії літературної мови: зміни в складі словника, в семантичній розробці та стилістичній характеристиці словникового складу в словнику будуть свідчити перш за все про рух і зміни самої мови, причому рух буде простежено не на

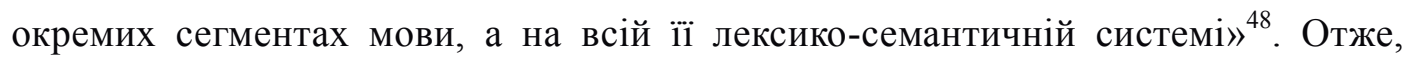
мовний матеріал нового тлумачного Словника відображає стихійний потік мовного життя, демонструє факти появи, зміни або входження в мову слів у всій їхній багатоманітності.

У тлумачному Словнику, метою якого є дати детальний аналіз різних аспектів застосування слова в літературній мові, лексика сучасної української мови представлена 3 максимальною повнотою та об'єктивністю, оскільки великі тлумачні словники орієнтовані на представлення всього лексичного обсягу української мови і по можливості всіх видів інформації про слово. Однією з причин появи тлумачних словників Л. В. Щерба вважає необхідність продемонструвати в них розвиток лексико-семантичної мовної системи: «Тлумачні словники виникають звичайно ... 3 метою встановлення мови, іiі нормалізації або пояснення тих чи тих її елементів, що є з яких-небудь причин не зовсім зрозумілими, ... а головне - кращого освоєння iï багатств. Тлумачні словники призначені для носія певної мови» ${ }^{49}$.

Водночас тлумачний Словник представляє усю складність лексикосемантичної системи, репрезентує усі вияви та сфери вживання лексики, адже «Розрізнити значення слів, установити їх точну семантику допомагає тлумачний словник. Відбиваючи сучасні лексичні норми, словник кваліфікує слова,

${ }^{48}$ Сороколетов Ф. П. Лексико-семантическая система и словарь национального языка // Современность и словари [ред. Ф. П. Филин и Ф. П. Сороколетов: сб. статей]. Л. : Наука, 1978. C. 18 .

${ }^{49}$ Щерба Л. В. Опыт общей теории лексикографии. Известия Академии наук СССР, Отделение литературы и языка. М., 1940. № 3. С. 112. 
словоформи і щодо їх уживаності, тобто вказує на застарілі, рідковживані, діалектні слова, а також на їх розмовне чи книжне стилістичне забарвлення» ${ }^{50}$.

Можна стверджувати, що саме Словник української мови в 20 -ти томах, який характеризується вичерпністю подання мовного матеріалу, дає можливість провести багатоаспектне вивчення сучасної української літературної мови, і в тому числі проаналізувати процеси неологізації мовного складу, спрогнозувати основні тенденції лексико-семантичного розвитку, встановити закономірності динаміки мови, виявити причини та фактори мовної еволюції.

Матеріал нового тлумачного Словника української мови засвідчує два найбільш активних процеси неологізації лексичного загальновживаного складу, які й стали об'єктом нашого дослідження. До них належать лексеми, що утворилися за дериваційними моделями, та семантичні інновації як результат вторинної номінації. Оскільки запозичень у новому СУМі зафіксовано порівняно невелика кількість, у нашій роботі розглядаються два різновиди неологізмів, представлені словниковою системою СУМа в 20-ти томах дериваційні та семантичні.

\section{2. Дериваційні неологізми в лексичній системі сучасної української мови}

\subsection{1. Словотворення як основний процес розширення словникового складу української мови}

Сучасні суспільно-економічні зміни знайшли відображення в появі великої кількості дериваційних неологізмів, освоєнні значної кількості запозичених слів, стилістичній переорієнтації лексики тощо. При цьому провідним процесом у динаміці словникового складу української мови $\epsilon$ творення нових слів із наявних у мові елементів. Поява нових слів шляхом деривації, як визнають мовознавці, відіграє головну роль у розширенні

${ }^{50}$ Русанівський В. М. Життя слова / В. М. Русанівський, С. Я. Срмоленко. К. : Вища шк. при КДУ, 1978. С. 32. 
лексичного складу [О. А. Земська, А. В. Мамрак, О. Г. Муромцева, Ю. С. Сорокін, О. А. Стишов, Ф. П. Філін та ін.].

Питання оновлення словника мови шляхом появи словотворчих інновацій, як визнають вчені, є актуальним і вимагає певних спеціальних досліджень, адже словотвір - це та сфера мовознавства, що знаходиться на межі граматики і лексикології.

Тісний зв’язок словотвору, що являє собою сукупність способів, правил утворення нових слів ${ }^{51}, 3$ граматикою та граматичною структурою мови виявляється перш за все в тому, що всі «нові слова розміщуються за тими граматичними категоріями, які властиві мові» ${ }^{52}$. Будь-яка інновація, що виникає в мовній системі, з'являється в ній як слово певного вже існуючого лексикограматичного розряду.

Поряд 3 цим, словотворення виявляє також тісний зв'язок із лексикою. 3 одного боку, це проявляється в тому, що слова (як лексичні одиниці) становлять основну словотвірну базу в деривації (сонце $\rightarrow$ сонячний); 3 іншого боку, основна функція словотворення - породження нових слів, вторинних лексичних одиниць, формування і розбудова лексичного складу мови (весна $\rightarrow$ веснувати, зима $\rightarrow$ зимувати $\rightarrow$ зимування $)^{53}$. Тому нові слова як дериваційні утворення стають об'єктом вивчення лексикології: новоутворені слова розглядаються як одиниці лексики, лексеми з усіма властивими їм ознаками.

Лексикологію споріднює із вченням про словотвір також те, що обидві ці мовознавчі дисципліни мають відношення до лексичного складу мови. Їх поєднує той фактор, що лексикологія «вивчає все те, що є продуктом i результатом процесів словотвору даної мови» ${ }^{54}$. I тому не дивно, що майже в усіх дослідженнях, присвячених характеристиці лексики, дослідники в більшій

${ }^{51}$ Шанский Н. М. Основы словообразовательного анализа. М. : Учпедгиз, 1953. С. 5.

52 Виноградов В. В. Стилистический аспект русского словообразования. М. : Наука, 1984. C. 2.

${ }^{53}$ Горпинич В. О. Сучасна українська мова. Морфеміка. Словотвір. Морфологія. К. : Вища шк., 1999. С. 80.

${ }^{54}$ Ермакова О. П. Вторичная номинация в семантической структуре многозначных производных слов // Способы номинации в современном русском языке [отв. ред. Д.Н. Шмелев]. М. : Наука, 1982. С. 63. 
або меншій мірі говорять про словотворчі засоби, наявні у досліджуваному лексичному складі.

Проте вивчення словотворення 3 граматичного та лексикологічного погляду має свої особливості. Так, граматичний підхід полягає в дослідженні творення нових слів в мові як процесу формування нових гнізд, розвитку певних відношень між словами - відношень генетичної залежності, з одного боку, і як процесу складання певних типів і розрядів слів, об'єднаних одним загальним, абстрактно-граматичним значенням, 3 іншого. При дослідженні словотвірних типів 3 граматичного боку в спільному типі виділяються внутрішні більш вузькі групи, що різняться модифікацією спільного граматичного значення, видозміною семантичних відношень між словами.

Із лексикологічного погляду утворення нових слів є таким процесом, де «...кожне утворене слово цікавить лексиколога не лише як член відомого спільного ряду, але і як окрема “особа”, як окремий “індивід”, носій свого особливого значення» ${ }^{55}$. У лексикологічному дослідженні розглядаються питання, в силу яких зовнішніх чи внутрішніх причин отримують особливий розвиток в мові ті чи інші словотворчі типи, як складаються семантичні відношення між словами, що належать до різних граматичних розрядів, в тому ж числі й питання про синонімічні відношення словотворчих варіантів слова.

Особливий інтерес 3 лексикологічного боку мають також семантикостилістичні відношення окремих словотворчих елементів, внаслідок яких в словниковому складі 3'являється неологізм. Наприклад, об'єднання в слові основ розмовного характеру i книжних афіксів, або, наприклад, книжних, нейтрально-термінологічних основ i експресивних розмовних афіксів, словотворчих елементів, за походженням запозичених і власне українських.

Таким чином, специфіка словотвору полягає в тому, що для утворення нових лексичних одиниць використовується інвентар словотворчих елементів морфем, і цим він зближається з граматикою, а за своїми результатами та

${ }^{55}$ Роль человеческого фактора в языке. Язык и картина мира / [Б. А. Серебренников, Е. С. Кубрякова. В. И. Постовалова и др.]. М. : Наука, 1988. С. 181. 
цілями, тобто утворення похідних одиниць номінації зі статусом слова, словотвір пов'язаний з лексичною системою.

У нашій роботі дослідження дериваційних новотворів здійснювалося шляхом поєднання обох підходів: граматичного (у рамках лексико-граматичних класів слів, в межах яких описані способи творення нових слів, їх словотвірні типи та засоби) та лексикологічного (у межах лексико-семантичних груп). Саме така методологічна позиція дала можливість системно представити функціонування неологічних дериватів у всій можливій повноті та багатоаспектності.

Як показав досліджуваний матеріал, деривати є одним із основних засобів розширення та збагачення діапазону Словника української мови неологічними утвореннями. Їх кількість становить більше 42 тис. слів. Активне поповнення лексичного складу дериваційними інноваціями викликано різними факторами. У галузі словотвору української літературної мови діє комплекс основних загальних закономірностей розвитку лексики, що виявляється в дії позамовних і мовних чинників, які сприяють реалізації словотворчого потенціалу мови, формуванню лексико-семантичних груп, а також сфер вживання інноваційних утворень.

Зрозуміло, що процеси формування нових слів різними словотворчими шляхами стають можливими перш за все завдяки системній організації словотвору, взаємодії та взаємозалежності між його різними способами. Про це неодноразово наголошують мовознавці [M. А. Жовтобрюх, О. А. Земська, I. І. Ковалик, С. О. Соколова, Ж. П. Соколовська, Ю. С. Сорокін та ін.]. Мова організована таким чином, що завдяки дериваційним процесам вона постійно реалізує свої можливості: спираючись на внутрішній словотворчий матеріал, а також запозичений з інших мов, українська словотвірна система має великий потенціал для утворення нових лексичних одиниць. Саме завдяки системній організації елементів словотвору виникає значна кількість нових слів шляхом деривації, що постійно поповнює лексичний запас мови. Ф. де Соссюр, вказуючи на значення системності у розвитку мови, зазначає: «Знак (морфема, слово, словосполучення) може існувати лише в системі, разом із іншими 
знаками. Кожен мовний знак сам по собі окремо не має в собі стимулів для 3мін»» ${ }^{56}$.

Крім того, мовними факторами, що визначають словотворчу активність, є дія закону «збереження мовної енергії» та тенденція до так званої «словотворчої аналогії на фоні словотворчих співвідносних зв’язків між основними і похідними словами» ${ }^{57}$. Зростаюча в суспільстві тенденція до збільшення інформативності, розширення обсягу, прискорення швидкості обміну та передачі інформації, безумовно, є одним із найактивніших чинників мовного розвитку, який сприяє економії мовних зусиль при збільшенні інформаційних можливостей мови. Саме тому використання носіями мови однослівних найменувань замість словосполучень - різного типу складних слів (композитів, скорочень, юкстапозитів та ін.) - є досить актуальним.

Важливим фактором, що сприяє реалізації словотворчої потужності української мови, стають також запозичення. Характерними процесами для лексичної системи мови є те, що в ній не тільки з'являється значна кількість інноваційних лексем іншомовного характеру, а й похідні від них дериваційні утворення. Тобто як тільки іншомовне слово починає вживатися в словесному оточенні мови-позичальника, воно звичайно адаптується до їі внутрішньої будови та середовища іiі мовних елементів, відбувається інтенсивний процес пристосування його до умов лексико-семантичної системи мови.

Також появі дериваційних неологізмів сприяє те, що у мові існують такі потенції (завдяки словотворчим можливостям i системній організації словотвору), які в певний момент, за певних умов реалізуються, спричиняючи виникнення в мові нових лексичних одиниць: «Те, що живе в мові прихованим життям, чого немає у поточному мовленні, але дано як натяк у системі мови, проривається назовні у подібних явищах мовного новаторства, перетворюючого потенціальне в актуальне» ${ }^{58}$.

${ }^{56}$ Соссюр Ф. де. Курс загальної лінгвістики. К. : Основи, 1998. С. 79.

${ }^{57}$ Ковалик I. I. Вчення про словотвір I. І. Ковалик. Львів : Вид-во Львів. ун-ту, 1961. Вип. 2 . С. 16.

${ }^{58}$ Винокур Г. О. Маяковский - новатор язика. М. : Сов. писатель, 1943. С. 15. 
Таким чином, активне входження нових слів до лексичного складу шляхом деривації зумовлене багатством словотворчого матеріалу української мови, закладеним в системі словотвору потенційними можливостями та закріпленим у ньому правилами творення. За словами українського мовознавця I. I. Ковалика, усі словотворчі величини в мові, багатогранні за своєю смисловою структурою i морфемною будовою, являють собою так звані словотворчі ресурси, тобто весь мовний матеріал, з якого вже утворились або ще утворюються нові слова різними словотворчими засобами. Всі ці ресурси використовуються в процесі постійного збагачення лексичного складу мови i служать одній меті - народженню нового слова, а тому всі вони входять у сферу словотворчого матеріалу $^{59}$. Таким чином у мові реалізуються регулярні процеси деривації лексичних одиниць, в результаті чого «Діяльнісний характер словотворення виявляється в “кінцевому продукті” цієї діяльності новоутвореннях того чи іншого часу» ${ }^{60}$.

Аналізуючи дериваційні неологізми, в своїй роботі ми спираємося на такі базові поняття, як словотвірна система, словотвірне значення, словотвірний тип, словотвірна модель та словотворчий елемент - морфема.

Вивчення закономірностей словотворення, специфіки використання словотвірних моделей, динаміки дериваційних процесів розкриває важливі тенденції мовного розвитку. Оскільки описовий словотвір української мови розглядає словотворчі процеси, які виявляють фактори іiі зміни на сучасному етапі $^{61}$, то важливим питанням, безсумнівно, залишаються способи дослідження цих закономірностей динамічного функціонування мови. Наше дослідження проведено на основі словотворчого аналізу 3 елементами морфемної сегментації. Цей метод, як підкреслив I. I. Ковалик, проводиться «з метою вияву синхронічно існуючих словотворчих величин та їх сполучень у

${ }^{59}$ Ковалик I. І. Вчення про словотвір I. І. Ковалик. Львів : Вид-во Львів. ун-ту, 1961. Вип. 2. С. 4.

${ }^{60}$ Земская Е. А. Словообразование как деятельность. М. : Наука, 1992. С. 201.

${ }^{61}$ Сучасна українська літературна мова : підруч. [для студ. філол. спец. вузів] / [за ред. А. П. Грищенка. Л. І. Мацько, М. Я. Плющ та ін.] [2-е вид. перероб. і доп.]. К. : Вища шк., 1997. C. 225 . 
конкретних словесних утвореннях» ${ }^{62}$. При словотворчому аналізі до уваги береться словотворча будова слова, встановлюється певна модель словотворення. Належність дериваційної одиниці до тієї чи іншої словотвірної моделі $є$ одним із базових положень нашої роботи, оскільки «Існування словотвірних типів і словотвірних моделей доводить існування зворотної закономірності: схожості валентних зв’язків лексичних одиниць, об’єднаних певною семантичною спільністю» ${ }^{63}$.

У роботі аналіз здійснюється за основними типами словотворення, які виявили продуктивність на досліджуваному матеріалі. Зазначимо, що продуктивність словотвірного типу є одним із опорних понять при аналізі дериваційних процесів у мові. Його сутність полягає в тому, що «Основний показник ступеня продуктивності того чи іншого словотвірного типу - те, настільки він $є$ активним зразком для поповнення нових слів у певному словотворчому ряді. Продуктивність словотвірного типу - це не тільки його словотворча здатність, а й перш за все його словотворча активність, тобто не тільки здатність чи можливість утворювати нові слова, а й здатність цієї можливості у словотворчих актах, внаслідок яких такі слова творяться» 64 .

Аналізуючи дериваційний процес творення нових слів та відповідні словотворчі морфеми, простежуємо той факт, що кожен словотворчий елемент має свої, властиві лише йому, досить визначені словотворчі зв’язки. «Кожна словотворча морфема має визначене коло слів і основ, 3 якими вона може поєднуватися в процесі словотворення і утворювати те чи інше слово» ${ }^{65}$.

Досліджуваний мовний матеріал демонструє ряд нових входжень, серед яких є лексичні одиниці, що відображають появу реалій останніх десятиліть, а також ті слова, що існували в мовній системі української мови, але не були

${ }^{62}$ Ковалик I. I. Вчення про словотвір I. І. Ковалик. Львів : Вид-во Львів. ун-ту, 1961. Вип. 2 . С. 31.

${ }^{63}$ Соколова О. С. Префіксальний словотвір дієслів у сучасній українській мові. К. : Наук. думка, 2003. С. 7.

${ }^{64}$ Словотвір сучасної української літературної мови / [за ред. М. А. Жовтобрюха]. К. : Наук. думка, 1979. С. 45.

${ }^{65}$ Шанский Н. М. Основы словообразовательного анализа. М. : Учпедгиз, 1953. С. 47. 
зафіксовані тлумачним словником в 11-ти томах. Стосовно двадцятитомного Словника ці лексеми є новими, і тому в нашому дослідженні вони віднесені до неологізмів.

Явище словотворення представлено у роботі 3 урахуванням лексикограматичних класів слів, оскільки специфіка дериваційних процесів перебуває в безпосередньому зв’ язку з класифікаційним поділом слів - словотворчі процеси української мови орієнтовані на формування лексичних одиниць різних частин мови, а також виявлення в їх межах твірних основ та продуктивних словотвірних типів, моделей, які наповнюються відповідними словотвірними значеннями, а також конкретних словотворчих формантів.

Розглянемо шляхи реалізації словотворчих ресурсів української мови, які відображені у лексикографічній системі Словника української мови в 20-ти томах.

\subsection{2. Іменникові інновації у складі лексики української мови}

\subsubsection{1. Іменникові деривати, утворені суфіксальним способом}

Утворення слів різних частин мови за допомогою механізму деривації відзначається нерівномірністю. У межах лексико-граматичних класів слів найбільша група інновацій представлена іменниками (реєстр СУМ-20 нараховує їх близько 20 500), оскільки зміни в суспільному житті особливо потребують нових номінацій на позначення осіб, понять, явищ, предметів тощо. Іменники становлять більше половини всіх нових слів. Це насамперед пояснюється тим, що «новоутворення служать перш за все засобом поповнення словника новими номінаціями, а саме іменники $є$ найбільш номінативним класом слів, що служить для називання нових реалій у всіх сферах життя людини» ${ }^{66}$.

Найпродуктивнішим при появі дериваційних іменникових неологізмів виступає морфологічний спосіб словотворення. Морфологічний спосіб - це

\footnotetext{
${ }^{66}$ Земская Е. А. Словообразование как деятельность. М. : Наука, 1992. С. 91.
} 
творення нових слів шляхом сполучення морфем за певними правилами в словесні єдності. Він, за словами М. М. Шанського, «є найбільш продуктивним, творчим і разом з тим найбільш граматичним... Саме цей спосіб є багатим, дійсно невичерпним джерелом поповнення словника, що являє собою нове явище не тільки 3 погляду семантики... але й звукового оформлення i морфологічної форми» ${ }^{67}$. $\mathrm{y}$ межах морфологічного способу найбільшу активність виявляють суфіксальний спосіб, осново- і словоскладання, а також абревіація.

Аналіз іменникових неологізмів, що утворилися в результаті процесу деривації суфіксальним способом, підтверджує той факт, що модифікування значення вихідної основи в похідному слові відбувається через словотворчу роль суфікса. Аналізуючи процес словотворення, Г. О. Винокур наголошував, що взагалі функція афікса полягає в тому, що він «дає можливість побачити ту ж основу в іншій перспективі, в одному із його бокових висвітлень, а тому i взагалі може мати який-небудь смисл тільки тоді, коли він застосований до будь-якої основи, а не існує сам по собі» ${ }^{68}$.

Розглянемо іменникові деривати, утворені суфіксальним способом, що є одним із основних в системі сучасного словотвору української мови. Порівняно 3 іншими частинами мови число іменникових суфіксальних формантів $\epsilon$ найбільшим. Саме цим, на думку вчених, пояснюється значне розширення словникового складу іменниковими дериватами (на відміну від інших частин мови), у творенні яких задіяний суфікс ${ }^{69}$. Зазначимо, що продуктивність або непродуктивність окремо взятих суфіксів $є$ поняттям відносним. I. I. Ковалик у своїх працях наголошував на тому, що «За підставу ступеня продуктивності слід брати не тільки окремо взяті суфіксальні складники слова, бо один і той самий суфікс в одних словотвірних типах може бути продуктивним, а в інших непродуктивним. У зв’язку з цим краще говорити про продуктивність цілого

${ }^{67}$ Шанский Н. М. Основы словообразовательного анализа. М. : Учпедгиз, 1953. С. 56.

${ }^{68}$ Виноградов В. В. Стилистический аспект русского словообразования. М. : Наука, 1984. С 132.

69 Земская Е. А. Современный русский язык. Словообразование. М.: Просвещение, 1973. C. 244 . 
словотвірного типу як найнижчого порядку основного словотвірного поняття» ${ }^{70}$.

Діапазон реалізації потенціалу суфіксальних утворень в досліджуваному матеріалі досить широкий. Вони використовуються на позначення абстрактної ознаки, опредметненої дії, осіб жіночої та чоловічої статі.

Значна кількість іменникових неологізмів 3'явилася в групі лексики із значенням абстрактної ознаки (абстрактні та збірні назви). Ці найменування завжди відносилися до продуктивного класу, що констатує у своєму дослідженні «Розвиток лексики слов’янських мов у післявоєнний період» В. Т. Коломієць: «Абстрактні назви ознак, процесів і станів є найбільшою за обсягом групою утворених суфіксальних іменників в усіх слов'янських $\operatorname{moвax»~}^{71}$.

Так, у реєстрі 20-томного словника 3’явилася велика кількість утворень, де виявив продуктивність словотвірний тип із суфіксом -ість (-ність), який задіяний для утворення номінацій із загальним словотвірним значенням «абстрактна ознака» не тільки в українській мові, але й в інших слов'янських мовах. Деривати цього класу мотивуються якісними та відносними прикметниками $з$ суфіксами -ив-, -н-, -лив- та ін. (адаптивний - адаптивність, акварельний - акварельність, альтернативний - альтернативність, вадливий вадливість). Ця словотвірна модель послужила утворенню цілої низки відприкметникових іменників (бар'єрність, бартерність, олігархічність, креативність, експансивність, шикарність).

До групи іменників на -ість (-ність) приєднується досить поширений ряд неологізмів, утворених від пасивних дієприкметників минулого часу на -ний (випробуваний - випробуваність, масштабований - масштабованість, прогнозований - прогнозованість). У цьому випадку поява згаданих утворень пов'язана з процесом ад'єктивації цих дієприкметників. У результаті вони

${ }^{70}$ Дешериев Ю. Д. Закономерности развития и взаимодействия языков в советском обществе. М. : Наука, 1966. С. 60.

${ }^{71}$ Коломієць В. Т. Розвиток лексики слов'янських мов у післявоєнний період. К. : Наук. думка, 1973. С. 264. 
набули значень, що стосуються характеристики особи, предмета чи явища, їхніх якостей, стану, властивостей (вмотивованість, деформованість, диференційовність, екстрагованість, політизованість).

Інша група дериваційних неологізмів представлена іменниками, що виражають властивість, стан або заняття особи, іiі титул, якусь суспільну громадську течію, релігійний напрямок. Ця група іменникових неологізмів утворена за допомогою суфікса -ств- (-цтв-). Деривати цього типу мотивовані переважно відносними прикметниками із суфіксами -ськ-, -цьк-, часто 3 паралельною мотивацією відповідними іменниками (адвокатський, адвокат адвокатство). Це стосується таких новоутворених іменникових лексем, як байкерство, барменство, ветеранство, віконтство, візирство, рейдерство, суперменство, сутенерство.

Серед зазначених іменників значне місце займають новотвори, які представлені словотвірним типом із суфіксом -ізм (-изм). Вони, як правило, похідні від відносних прикметників із суфіксами -н-, -ичн-, -ськ(абсурдистський, абсурдний - абсурдизм). Цей словотвірний тип виявляє свою продуктивність переважно при формуванні наукової термінології. Лексеми на позначення наукових понять в українській мові займають значне місце серед інноваційних входжень.

До групи найчастотніших новотворів слід віднести також інноваційні утворення на позначення опредметненої дії або процесу. Нові слова становлять групу іменників середнього роду на -нн-я із загальним словотвірним значенням опредметненої дії (процесу). Як відомо, в сучасній українській мові ці утворення в групі суфіксальних іменників різного роду становлять основну масу серед розрядів віддієслівних іменників. Морф -нн-я активно використовується у віддієслівних утвореннях (частіше від дієслів недоконаного виду) із суфіксами основи -а- (-я) або -ва-, -ува- (-юва-) (напр. адвокатувати адвокатування, абсолютизувати - абсолютизування, абонувати - абонування, зміщцаніти - зміщзаніння). Продуктивність цього словотвірного типу відображена в інноваційних іменникових неологізмах на позначення опредметненої дії, представлених в новому Словнику української мови: 
абеткування, абортування, банкрутування, вславлювання (уславлювання), видрукування, висвічування, легалізування, лексикографування.

У творенні іменників із словотвірним значенням опредметненої дії не менш продуктивними є суфікси іншомовного походження -аці-я (-яці-я), -ці-я, -кці-я, -і-я (вакуолізувати - вакуолізація, ваучеризувати - ваучеризація, абстинент - абстиненція), де новоутворені лексеми мотивовані дієслівними та іменниковими основами. Нові лексеми цієї групи позначають наукові поняття, які сьогодні досить активно проникають в мову.

Активно поповнилася неологізмами також група іменників на позначення осіб. Ці слова, що з'явилися в результаті процесу деривації, відображають взаємодію зовнішніх та внутрішніх факторів мовної динаміки. Це зазначає О. А. Стишов, який досліджував розвиток лексичної системи української мови кінця XX століття: «Позамовні фактори сприяють динамічному продукуванню лексем цієї групи, що зумовлене постійною потребою номінації (нерідко прагматичного характеру) нових осіб, зокрема за належністю до певної соціальної групи, організації, об'єднання за певним типом занять і т. ін. чи якоюсь іншою специфічною особливістю. Внутрішньомовні ж чинники не перешкоджають входженню зазначених новотворів до лексичної системи української мови, оскільки процес деривації відбувається за наявними в українській мові словотвірними типами і моделями» ${ }^{72}$.

У системі найменувань осіб значне місце посідають інноваційні назви діячів. При цьому велику групу новотворів становлять іменники чоловічого роду із загальним словотвірним значенням «особа чоловічої статі». Досить продуктивним тут виявився словотвірний тип із суфіксами -ник (-ик), для творення якого послужили основи іменників. Деривати цієї групи позначають особу за родом іiі діяльності (вагонетка - вагонетник, вагон - вагонник, антена - антенник, арбалет - арбалетник, басон - басонник, естрада естрадник, ікра - ікряник); іноді вони пов'язані з найменуваннями в науковотехнічній сфері (вакуум - вакуумник).

72 Лексика русского литературного языка XIX начала XX века / [отв. ред. Ф. П. Филин]. М.: Наука, 1981. С. 124. 
Спостереження над сучасними інноваціями демонструє недостатньо активне входження відіменникових субстантивів на позначення «особа чоловічої статі», що утворені за допомогою суфікса іншомовного походження| -ист (-іст) від повних або усічених основ: батут - батутист, алгебра алгебрист. Деривати цього типу позначають осіб за їх відношенням до певного поняття, сфери діяльності (прокурист, процесуаліст, авторитарист, алебардист, банджист, бар'єрист, бесист, вікіпедист, грейдерист), громадського, релігійного чи іншого напрямків (абсурдист, афроиентрист, іредентист, патерналіст, тантрист) тощо.

У межах зазначеної групи лексики функціонує значна кількість іменниківновотворів на позначення осіб жіночої статі. Поява багатьох 3 них викликана зростанням активності та ролі жінки в сучасному суспільстві, виконанню нею таких функцій, які раніше були прерогативою чоловіків. Іменникові неологізми на позначення жіночої статі, як правило, мають у мовленні відповідники на позначення чоловічих назв. Для творення назв жінок в обстеженому матеріалі використовуються суфікси -к-а та -иц-я.

Досить велику групу нових дериваційних утворень становлять найменування жінок, мотивовані іменниками чоловічого роду зі значенням особи - словотвірний тип з суфіксом -к-а. Складовими цього словотвірного типу $\epsilon$ утворення від повних або усічених основ відповідних іменників чоловічого роду з суфіксом -ист (-іст, -їст): абсолютист - абсолютистка, абстракціоніст - абстракиіоністка, африканіст - африканістка, батутист батутистка, еготист - еготистка, біатлоніст - біатлоністка, батерфляїст - батерфляїстка, візуаліст - візуалістка, бобслеїст бобслеїстка, енциклопедист - енцчиклопедистка; iз суфіксом -ер (-ср): акцііонер - акцііоерка, вахтер - вахтерка, байкер - байкерка, корупціонер корупціонерка, міліц̧іонер - міліціонерка, прем'єр - прем'єрка (розм.); із суфіксом -ар: варвар - варварка, картотекар - картотекарка; із суфіксом -ір: банкір - банкірка (розм.); із суфіксом -ор: аматор - аматорка. Одні 3 наведених лексем поповнюють словниковий склад найменуваннями 
професійних занять особи, спортивної діяльності, характеристичної оцінки тощо.

У межах словотвірного типу на позначення осіб жіночої статі поширеною у сучасній мові також є модель із суфіксом -ищ-я (-ниц-я). Ці деривати утворено від співвідносних назв чоловічого роду різними способами. Суфікс -иц-я приєднується до усічених основ іменників чоловічого роду із суфіксом -ик (-ник). Наприклад, вагонник - вагонниця, вакуумник - вакуумниця, валютник - валютниця, атакувальник - атакувальниця, варильник варильниця, вертолітник - вертолітниця, байдарочник - байдарочниця, бальзамувальник - бальзамувальниця, барахольник - барахольниця, дозувальник - дозувальниця, екскаваторник - екскаваторниця, ізолювальник ізолювальницяя. Це переважно слова, що називають особу за сферою іiі професійної діяльності.

Деякі інноваційні іменники жіночої статі з'явилися на основі новоутворених в СУМі іменників чоловічого роду з вищеназваними суфіксами і репрезентовані в СУМ-20 як парні неологізми. Наприклад, атакувальник атакувальниця, афроамериканецьь - афроамериканка, виправляч - виправлячка.

\subsubsection{2. Складні неологізми в системі СУМ-20}

У поповненні лексичного складу мови значну роль відіграють дериваційні неологізми, що являють собою групу складних іменникових утворень. Їхня поява обумовлена рядом факторів, які спричиняють розвиток лексичної системи мови.

Перш за все, складні слова - це найбільш економний засіб номінації. Вони свідчать про діючий в мові закон збереження лінгвістичної енергії, що $\epsilon$ важливим чинником у період значного розширення інформаційного пласту. Дослідники зробили висновок, що людина завжди намагається отримати оптимальний результат при мінімальних затратах. Таке прагнення $\epsilon$ характерним і для мовленнєвої діяльності. I. О. Бодуен де Куртене, описуючи причини мовних змін, зазначав, що «всі зміни можна підвести під одне головне 
намагання, вроджене людському організму, а саме намагання до економії роботи: роботи м’язів, роботи нервових відгалужень, роботи центрального мозку. Це намагання викликає в індивідуумів спорадичні спроби, що постійно повторюються, які, врешті, стають фактом у мові... якої-небудь групи людей» ${ }^{73}$.

Крім закону збереження мовної енергії, у процесі утворення складних слів суттєву роль відіграє також закон словотворчої аналогії, варіативності. У результаті утворення слів за аналогією вихідна одиниця виступає словотворчим матеріалом, а інноваційні лексеми постають на базі вже існуючих у мові лексем та словосполучень. На думку дослідників, якщо «...поняття, що виникли знову, можуть позначатися назвою старих, то й позначення окремих понять можуть бути “сполученням слів”, що є в такому випадку “словами” або принаймні “потенційними словами”»74. Такі сполучення слів Л. В. Щерба відносить до лексичних одиниць. Він вважає, що словосполучення й похідні слова, які їх замінюють, відрізняються від них лише формально.

Зазначені чинники знаходять своє вираження в заміні словосполучень, що носять, як правило, характер стійких мовних номінацій, однослівними найменуваннями, які є більш економними за своєю формою і відповідають змістовому наповненню мовного знака, що відіграє роль твірної одиниці.

Оскільки складні дериваційні утворення мають дві і більше твірних основ, то вони містять значну кількість інформації, яка економно поєднується в утворених номінаціях. Словник складних іменникових інновацій становить переважно термінологічна та спеціальна лексика різних науково-технічних галузей. Ці іменникові новотвори в новому СУМі помітно розширили межі термінолексики та загальновживаних слів. Зростання продуктивності складного способу складання в останній час засвідчують усі дослідники. За даними науковців (Ю. А. Зацний, Д. В. Мазурик, О.А.Стишов), складні деривати кількісно поступаються лише суфіксальному способу словотвору.

${ }^{73}$ Бодуэн де Куртенэ И. А. Избранные труды по общему языкознанию. М.: Изд-во АН CCCP, 1963. Т. 1.384 с.; Т. 2. С. 248.

${ }^{74}$ Щерба Л. В. Что такое словообразование (тезисы доклада). Вопр. языкознания. 1962. C. 99 . 
Процес виникнення складних іменникових неологізмів здійснюється такими основними шляхами: словоскладання (юкстапозиція та зрощення), абревіація та основоскладання (композиція). Дериваційною основою утворення юкстапозитів, композитів і абревіатур, за словами Л. О. Кудрявцевої, є лексична конденсація, коли в похідному слові план змісту лексичних одиниць вихідної синтагми і відповідний їм план вираження представлений у редукованому вигляді. Дослідниця зазначає, що «редукція плану вираження вихідної синтаксичної структури має різний ступінь вияву: від мінімального при юкстапозиції до максимального при ініціальній абревіації» ${ }^{75}$.

\subsubsection{3. Нові юкстапозити та зрощеннєві утворення}

Одним iз способів словоскладання, який виявив значну активність у творенні інновацій, $є$ юкстапозиція. Юкстапозити являють собою лексичні одиниці, для яких характерне поєднання двох чи більше компонентів без сполучних голосних, де формальну і семантичну цілісність передає дефіс між ними.

Інтенсивному творенню складних лексем шляхом юкстапозиції, i, як наслідок, появі їх у тлумачному словнику, послужив власний словотворчий потенціал української мовної системи. Поряд з цим, поповненню словникового складу лексемами складного типу сприяли i запозичені елементи. Реєстр СУМ-20 розширився завдяки новотворам, до складу яких входять компоненти іншомовного походження. При цьому серед інноваційних субстантивівюкстапозитів немало таких, в яких є словотворчі форманти-інтернаціоналізми, поширені в багатьох мовах світу. Запозичені слова або елементи слів у процесі деривації переоформляються згідно 3 словотворчими зразками мови, що їх засвоює. «Входженню та активному використанню великої кількості запозичень сприяє процес глобалізації, який передає насамперед інформаційну відкритість,

${ }^{75}$ Кудрявцева Л. А. Моделирование динамики словарного состава языка / [2-е изд.]. К. : ИПЦ «Киевский университет», 2004. С. 133. 
яка здійснюється через такі інформаційні середовища, як телебачення, радіо, преса, інтернет» ${ }^{76}$.

Цей тип словотворення виявив велику продуктивність на сучасному етапі розвитку мови, в результаті чого реєстр СУМ-20 поповнився новими одиницями. Серед цих складних одиниць переважають лексеми, побудовані 3 двох іменників iз дефісним написанням. Тенденції цього способу продукування слів поширюються як на творення термінів та номенклатури (які представляють основну масу лексем цього типу), так і на загальновживану лексику.

Варто відзначити, що аналізований масив лексики показав, що у нових репрезентантах СУМа - юкстапозитах - різне лексичне наповнення. У новотворах поєднуються як власне українські елементи (крісло-ліжко, нечіпай-зілля, ложка-миска, ракета-носій), так і питомі та запозичені або лише запозичені (експрес-служба, панк-культура, ритм-секція, гамма-квант), причому такі утворення становлять основну частину інноваційних субстантивних юкстапозитів.

Аналіз реєстру неологізмів СУМ-20 свідчить, що словотворча активність юкстапозиції активно проявилась у такій сфері життєдіяльності людини, як мистецтво. Формування нових мовних одиниць цієї сфери відображає розвиток мистецтва та музики, підвищення рівня обізнаності в сфері культури, зміну музичних смаків тощо. Як показало дослідження, у новому тлумачному словнику продуктивністю відзначаються іменникові юкстапозити, словотвірна модель яких містить різні словотворчі елементи. Насамперед слід назвати лексеми, до складу яких входять такі форманти, як бек- (бек-вокал, беквокаліст, бек-вокалістка), джаз- (джаз-оркестр, джаз-фестиваль, джаз-рок), гала- (гала-виставка, гала-концерт, гала-спектакль). Також у Словнику помітно активізувалися форманти дубль- (дубль-бекар, дубль-бемоль, дубльдієз) та рейв- (рейв-клуб, рейв-культура). Порівняно рідко з'являються юкстапозити 3 іншими формантами, що $\epsilon$ складниками таких лексем, як,

76 Зацний Ю. А. Розвиток словникового складу англійської мови в 80-ті роки ХХ ст.: дис. ... доктора філол. наук: 10.02.04. Запоріжжя, 1999. С. 16. 
наприклад, диск-жокей, компакт-диск, поп-музика, майстер-клас, техно-група, джаз-рок, блек-метал.

Досліджений матеріал дериваційних неологізмів, які представляють мистецьку сферу, дав підстави виділити наступні семантичні класи слів: позначення музичних стилів, найменувань сучасних напрямків музики та сучасної інтерпретації колишніх найменувань, осіб, що працюють у музичному середовищі та ін.

Кінець XX - початок XXI століття позначений не лише змінами в галузі науки та техніки, музики та мистецтва, а й масштабними соціальноекономічними перетвореннями, ускладненням форм суспільного життя, переформуванням політико-організаційних структур та ін., що знайшло відображення в новій лексиці, яку репрезентує новий СУМ у 20-ти томах.

Його дослідження показує, що значних змін зазнала суспільно-політична лексика, яка стала одним із джерел поповнення словникового фонду української мови. Значну за обсягом групу становлять іменники із складовим формантом віце-, що нараховує більш як 20 компонентів словотворчого гнізда (віце-голова, віц̧е-губернатор, віц̧е-консул, віцее-прем'єр, віц̧е-директор, віц̧е-прем'єрство, віце-спікер, віце-спікерство, віuе-спікеріада та ін.). Лексичні одиниці цього типу містять у своєму складі два елементи, за винятком слова віųе-прем'єpміністр. Зазначені лексеми демонструють поповнення Словника української мови новотворами із семантикою на позначення переважно посад осіб та часу діяльності особи на певній посаді.

У складі словотворчих елементів значну активність виявив також компонент соціал- (соціал-патріот, соціал-нацүіоналізм, соціал-націоналіст, соцііал-реформізм, соціал-реформіст), який утворює ряд слів на позначення здебільшого назв політичних течій та осіб, що називають їх представників.

Аналіз досліджуваного матеріалу продемонстрував, що Словник поповнився групою лексем на позначення понять, пов’язаних із бізнесом, економікою, фінансовими стосунками, юриспруденцією. У СУМ-20 фіксуються нові слова, утворені внаслідок процесу юкстапозиції, що містять словотворчий елемент банк-, який виявив значну продуктивність (банк-гарант, банк- 
кореспондент, банк-дилер, банк-акцептант, банк-емітент). При творенні інноваційних лексем істотно активізувався також формант брутто- (бруттоприбуток, брутто-продаж, брутто-відсотки, брутто-проиенти, бруттооренда). Інноваційні іменники з'явилися також унаслідок словотворчої активності компонента бізнес- (бізнес-план, бізнес-проект, бізнес-каталог, бізнес-карта). Лексична семантика аналізованих дериваційних неологізмів, представлених у Словнику в 20-ти томах, має досить широкий діапазон. У групі іменників із зазначеними вище словотворчими компонентами це семантичні об'єднання для найменувань фінансових операцій, видів комерційної діяльності, установ, які здійснюють фінансові операції та ін.

Для творення іменникових неологізмів-юкстапозитів задіяний також формант брокер-, представлений у Словнику в складі таких лексем: брокерaymсайдер, брокер-комісіонер. Цей компонент може виступати і в постпозиції, але на нашому матеріалі лише в одиничному прикладі (біл-брокер). У новому 20-томному СУМі трапляються поодинокі деривати, утворені за допомогою інших компонентів словотворення, наприклад: дато-вексель, грин-кард, картблани, крос-курс. Ця група лексики, зафіксована в новому тлумачному словнику, використовується для найменування осіб - представників фінансової сфери, а також різних ділових паперів та документів (фінансових та юридичних). Виникненню таких утворень в лексичній системі української мови значною мірою сприяла поява нових економічних стосунків, фінансових зв'язків, комерційна діяльність та ін.

Розвиток мас-медіа - засобів масової інформації: реклами, преси, радіо, телебачення - сприяе поповненню словникового складу інноваційними одиницями, в тому числі й дволексемними. Засоби масової інформації завжди відігравали велику роль у формуванні політичної культури та політичного світогляду людей, у соціокультурній орієнтації суспільства. Сучасний етап розвитку суспільства характеризується появою нових інформаційних технологій, новітніх видів засобів масової інформації, що також відіграє свою роль у динаміці лексичного складу української мови. Цей напрямок утворення інновацій реалізується через використання формантів, які є породженням 3МІ і 
виявили значну продуктивність у Словнику української мови: прес- (пресгрупа, прес-центр, прес-клуб, прес-випуск, прес-галерея, прес-бюлетень), медіа(медіа-магнат, медіа-простір, медіа-цеентр, медіа-планування, медіа-група), бліц- (бліц-вікторина, бліu-інтерв'ю, бліu-опитування), експрес- (експресінформація, експрес-служба, експрес-видання).

Поміж інших складних дериваційних неологізмів, що представляють поодинокі словотворчі елементи, назвемо лексичні одиниці типу секретарреферент, топ-модель, генерал-адмірал, генерал-полковник. Слова 3 цими формантами вживаються на позначення роду діяльності чи професії. Зазначимо, що твірні основи нових лексем (-референт, -модель) вже існували (були представлені в 11-томному Словнику) як окреме слово, складні ж новоутворені найменування уточнюють, виокремлюють вид професійної зайнятості особи.

Кількісно невеликою $є$ лексика на позначення предметів домашнього вжитку: крісло-ліжко, диван-ліжко, чайник-кип'ятильник та на позначення рослин зі складником -зілля у постпозиції: нечіпай-зілля, розмай-зілля, чарзілля. Зазначимо, ця остання група лексики утворена за допомогою формантів українського походження.

Невелика кількість зафіксованих у сучасному Словнику нових іменників утворилися завдяки дії словотворчого процесу зрощення, що є результатом поєднання двох або кількох синтаксично пов'язаних слів. Цей словотвірний тип характеризується зафіксованим порядком частин та наголошенням опорного компонента. «Зрощення у всіх своїх формах тотожні по морфемному складу синонімічним сполученням, на основі яких вони утворені» ${ }^{77}$. Такі утворення виникають переважно на основі двох слів, але, на відміну від словосполучення, вони мають не вільний, а закріплений порядок, наприклад: авіарозвідка, авіасалон, авіапродаж.

Досить великої ваги серед складних дериватів набули зрощення, складовими компонентами яких є авіа- (авіапатруль, авіапатрулювання, авіалайнер, авіатехніка, авіакатастрофа), відео- (відеоадаптер, відеооператор, відеотекст,

${ }^{77}$ Современный русский язык. Словообразование / [за ред. Е. А. Земской]. М. : Просвещение. 1986. С. 24. 
відеоапаратура, відеоллеєр), кіно- (кінохронікер, кінофірма, кінобізнес), авто(автотурист, автоштурман, авточивілка). Звичайно, складні утворення, що містять у складі такі компоненти, як авто-, авіа-, і раніше мали значне поширення. Сучасні тенденції розвитку словникового складу характеризує активізація таких компонентів творення слів, як кіно- та відео-.

\subsubsection{4. Нові абревіатури в словниковому складі української мови}

Досить значну за обсягом групу новотворів СУМ-20 сформували абревіатури та складноскорочені слова, що виникли внаслідок процесу абревіації, що є свідченням активного процесу творення неологізмів способом скорочення на сучасному етапі розвитку мови. Про значне входження неологізмів-абревіатур у лексичний склад пишуть у своїх роботах такі дослідники, як Ю. А. Зацний, О. А. Земська, Н. Ф. Клименко, О. А. Стишов та ін.

Оскільки в мові абревіація виконує компресивну функцію, тобто служить для утворення більш коротких, ніж співвідносні словосполучення, номінацій, то розширення словника української мови, що відбулося за рахунок абревіації, $є$ закономірним процесом. Потужним внутрішньомовним стимулом появи абревіатур є дія закону економії мовних зусиль. Як відзначають дослідники, це відповідає культурному прагненню сучасного суспільства до збільшення інформативності тексту за рахунок його скорочення, а також певним прагматичним прагненням - економії площі друкованої продукції та часу усних повідомлень ${ }^{78}$.

Результатом дії закону збереження лінгвістичної енергії $\epsilon$ заміна словосполучень однослівними знаками (складними словами) як більш економними та зручними за формою. Складноскорочені слова, що демонструють процес абревіації, який пов'язаний з раціоналізацією мови, дійсно економні, оскільки скорочують «площу» словесних знаків. Абревіатури, як і інші складні слова, компактні за своєю структурою і в той же час їх

${ }^{78}$ Гулыга Е. В. Новое и старое в лексике и грамматике немецкого языка / Е. В. Гулыга, Е. В. Розен. Л., 1997. С. 65. 
семантика зрозуміла, що й обумовлює їх перевагу перед словосполученнями. Вони є «масовим явищем, що прагне зламати деякі жорсткі норми мови й тим стимулювати їі розвиток» ${ }^{79}$.

У сучасній мовній системі абревіатури представлені трьома типами: часткові (комбіновані), ініціальні з трьома підтипами (літерні, звукові, літернозвукові) та складові (із початкових частин слів).

Обстежений мовний матеріал інноваційної лексики СУМ-20 свідчить, що найбільш масовим процесом поповнення його реєстру абревіатурами є поява часткових абревіатур. Лексеми, що належать до цього словотворчого типу, являють собою структури, що формуються на базі скорочення одного або кількох елементів твірної синтаксичної моделі (базового словосполучення) за умови збереження одного повного слова. Наприклад: дезінфекційна камера дезкамера, дієтичний магазин - дієтмагазин, європейський парламент європарламент, економічна зона - економзона, терористичний акт - теракт, туристичне замовлення - турзамовлення. Саме наявність у складі абревіатур одного повного слова сприяє прозорості їх внутрішньої форми, адже «...складові частини похідного слова не тільки передають значення кожного члена вихідної синтагми, але й зберігають більшою або меншою мірою план вираження вихідної одиниці» ${ }^{80}$.

3 формального боку ці складноскорочені новотвори $є$ переважно структурами, утвореними шляхом поєднання двох елементів: господарський договір - госпдоговір, начальник итабу - начитабу, муристична фірма турфірма, канцелярське приладдя - канциприладдя. Рідше зустрічаються лексеми, до складу яких входять три компоненти: обласна державна адміністрація - облдержадміністрація, районна ветеринарна лікарня райветлікарня, сільський будівельний комбінат - сільбудкомбінат, судова медична експертиза - судмедекспертиза.

${ }^{79}$ Алексеев Д. И. Сокращенные слова в русском языке. Саратов : Изд-во Саратов. ун-та, 1979. С. 24.

${ }^{80}$ Кудрявцева Л. А. Моделирование динамики словарного состава языка / [2-е изд.]. К. : ИПЦ «Киевский университет», 2004. С. 119. 
Розгляд механізму формування нових дериваційних лексем підтверджує той факт, що інвентар словотворчих засобів представляє різноманітний арсенал дериваційних засобів мови. Джерелом виникнення інноваційних абревіатурних утворень послужило активне залучення як запозичених, так i власне українських елементів. Значну питому вагу в Словнику мають інновації, де одним із елементів $\epsilon$ компонент іншомовного походження, що піддався скороченню. Саме запозичення (в ролі першої скороченої частини новоутвореної лексеми) створюють умови для формування цілої низки нових слів цього типу. В обстеженій лексиці виявлено слова з такими продуктивними іншомовними компонентами: свро- (від європейський): європарламент, євродолари, європростір, євровалюта, еко- (від екологічний): екосистема, екоресурси, екокатастрофа, енерго- (від енергетичний): енергоджерело, енергокомплекс, енергоносій, соціо- (від соціологічний): соціоекологія, соиіолінгвістика, соиіооиінка, нарко- (від наркотичний): наркозбут, наркоторгівля, нарколікарня. Кількісно меншою виявилася група лексем із словотворчим формантом проф- (від професійний і профспілковий): профвідпустка, профзахворювання, профробота. Інноваційні іменникові лексеми переважно представляють лексичні одиниці, що функціонують в соціальній, політичній, економічній, біологічній та ін. сферах діяльності людини.

У процесі утворення частковоскорочених абревіатур задіяні також власне українські елементи. Так, наприклад, активною твірною морфемою серед нових іменників виступає елемент держ- (від державний) (це словотворче гніздо нараховує більше 20 одиниць): державне замовлення - держзамовлення, державний контроль - держконтроль, державний кордон - держкордон, державний кредит - дежкредит, державна торгівля - держторгівля, державний бюджет - держбюджет, державний секретар - держсекретар, державна позика - держпозика. У такий спосіб з'явилися нові слова, першою частиною яких є політ- (від політичний): політреформа, політкоректність, nолітапарат. 
Значний інтерес із лексико-семантичного погляду представляє у словотворенні розгляд найбільш поповнюваних лексико-семантичних груп слів. Ця лексика переважно є загальновживаною, широко розповсюдженою в різних стилях літературної мови. Значне місце серед складних утворень займають також спеціальні слова, які беруть активну участь у формуванні різних термінологічних сфер.

У досліджуваний період відбувається значне розширення групи іменників, пов'язаних із номінаціями у сфері промисловості та виробництва. Соціальна обумовленість таких новотворів цілком очевидна, адже стрімкий розвиток різних сторін виробничої діяльності людини привів до збільшення кількості вербальних знаків, що доповнили словниковий склад цієї лексичної групи. Найбільш продуктивною словотвірною моделлю тут стали утворення, що містять компонент госп-: господарський договір - госпдоговір, господарський орган - госпорган, господарська частина - госпчастина; харчо-: харчовий блок - харчоблок, харчовий комбінат - харчокомбінат, харчовий mрест - харчотрест. Поодинокі випадки представлені лексемами з формантом мат-: матеріальна частина - матчастина.

Групу дериваційних неологізмів цього типу в досліджуваному матеріалі складають слова адміністративно-політичної сфери, утворенню яких сприяв розвиток політичного, суспільно-економічного життя українського суспільства. Серед нової політичної лексики слід назвати такі інноваційні одиниці: політичний апарат - політапарат, обласна рада - облрада, політична реформа - політреформа, адміністративний персонал - адмінперсонал, державний департамент - держдепартамент.

Зміни, які відбулися в економічних, фінансових сферах діяльності людини, представлені в сучасній мові такими інноваційними одиницями: грошовий знак - грошзнак, економічна зона - економзона, капітальні вкладення - капвкладення, ощуадна книжка - ощуадкнижка, страхова каса страхкаса, страховий фонд-страхфонд.

Зросла кількість інноваційних одиниць, що представляють групу лексики медицини. Розвиток цієї галузі знань демонструє ряд нових входжень у 
словниковий склад мови. Медичний лексикон представлений у СУМ-20 наступними інноваціями: дезінфекціійна камера - дезкамера, медична допомога - меддопомога, психологічна діагностика - психодіагностика, медичне обслуговування - медобслуговування. Формування нових словесних знаків з елементом діст- також розширило групу лексем цієї галузі: дієтична їдальня - дієтїдальня, дієтичні продукти - дієтпродукти, дієтичний магазин дієтмагазин.

Нові складні утворення збагатили також словник військової справи. В обстеженому масиві СУМ-20 низка слів представляє таку військову лексику: артилерійський вогонь - артвогонь, артилерійський обстріл - артобстріл, артилерійська підготовка - артпідготовка, моторизована дивізія мотодивізія, командир ескадрону - комескадрону, начальник итабу начштабу, військовий технік - військтехнік.

Одну із лексико-семантичних груп складають нові словесні утворення на позначення закладів, установ, об'єднань та організацій: туристична фірма турфірма, кореспондентський пункт - корпункт, таксомоторний парк таксопарк.

Неабияку роль у поповненні складноскорочених лексем відіграють абревіатури, пов'язані 3 освітою. Лексичний фонд цієї групи представляє широке коло одиниць на позначення педагогічних закладів, видів роботи у педагогічній сфері і т. п., де продуктивним елементом є пед-: педагогічний колектив - педколектив, педагогічна практика - педпрактика, педагогічна рада- педрада. Меншу продуктивність має формант метод-: методичний кабінет - методкабінет, методична розробка - методрозробка. Зазначені лексеми, що пов’язані 3 педагогічною діяльністю, переважно представляють лексику, яка існувала в мові, але не ввійшла в 11-томний Словник української мови.

Дещо меншу за обсягом групу, порівняно 3 попередніми, становить інноваційна спортивна лексика: спортивний клуб - спортклуб, спортивний комітет - спорткомітет, спортивний комплекс - спорткомплекс, спортивне обладнання - спортобладнання. 
Невелику чисельність мають також новотвори на позначення професій та посад (завідувач (завідувачка) кадрів - завкадрів, ветеринарний лікар ветлікар). Переважно це абревіатури, утворені за допомогою препозиційного компонента зав-: завідувач відділу - заввіділу, завідувач (завідувачка) клубу завклубу.

До групи малопродуктивних лексем належать також одиниці на позначення предметів та приладів (канцелярське приладдя - канцприладдя, канцелярські товари - канцтовари), математичної та технічної термінології (запасна частина - запчастина, математичний аналіз - матаналіз), понять, пов'язаних $з$ побутом (капітальний ремонт - капремонт).

Проведене дослідження показало, що ініціальні абревіатури 3 їх двома підтипами: літерні (утворені із початкових букв слів) та звукові (утворені із початкових звуків слів) представлені дещо меншою кількістю, ніж часткові абревіатури. Серед них продуктивними $є$ словотвірні моделі, які формують характерні для досліджуваного часу лексико-семантичні групи.

Кількісно найбільшою серед ініціальних абревіатур є група літерних утворень: Служба безпеки Украӥни - СБУ, міжбібліотечний абонемент - МБА, дорожно-транспортна пригода - ДТП. Значно меншою є група звукових новотворів, яка ілюструє одиниці на зразок: Нащііональна академія наук України - НАНУ, засоби масової інформащзї̈- ЗМІ. Слід зазначити, що літернозвукове абревіатурне утворення в новому Словнику української мови зафіксовано лише одне: дитячо-юнацька спортивна школа - ДЮСШ.

У досліджуваний період ці новотвори займають вагоме місце в загальному процесі збагачення словникового складу української літературної мови. Буквеними та звуковими абревіатурами інтенсивно поповнюються певні лексико-семантичні групи. Найбільш характерним процесом є розширення складу груп на позначення понять сфер державних та міжнародних відносин, науки і техніки та ін. Перш за все ці слова утворюються на позначення нових реалій, що виникли в результаті різних змін в країні та світі (визнання України як незалежної держави, входження країни до організацій світового рівня, розширення міжнародних зв’язків, поява нових організаційних утворень): 
Співдружність Незалежних Держав - СНД, Свропейський Союз - $С$, Свропейське економічне співтовариство - СЕС, вільна економічна зона - ВЕЗ, Організація украӥнських націоналістів - ОУН.

Потреба у вербалізації нових понять науково-технічної сфери викликала появу найменувань на позначення приладів, процесів та ін., із яких певні одиниці існували в мові, але не були зафіксовані Словником в 11-ти томах. Наприклад: електронно-обчислювальна машина - ЕОМ, електрокардіограма - ЕКГ, радіолокаційна станція - РЛС, надвисокочастотний - НВЧ, поліхлорвініл - ПХВ, радіолокаційна станція - РЛС, ультрависока частота - УВЧ.

3'явилися нові лексеми, що вживаються як назви державних адміністративних органів, організацій, установ тощо: загін міліції особливого призначення - ЗМОП, державна автомобільна інспекція - ДАІ, добровільна народна дружина - ДНД, фабрично-заводський комітет - ФЗК.

Меншу за обсягом групу слів, порівняно з попередніми, становлять складові абревіатури, утворені з початкових частин слів (на основі словосполучень, у яких усічення зазнали всі компоненти). Причому складноскорочення утворені тут шляхом поєднання переважно двох компонентів (завідувач лабораторії-завлаб, історичний факультет - істфак, начальник медичного закладу - начмед), рідко трьох (підприємство сільського машинобудування - сільмашбуд, промисловофінансовий план - промфінплан, центральна виборча комісія - центрвиборчком), і лише в одному випадку - чотирьох (фабрично-заводський місиевий комітет фабзавмісиевком). Найбільш характерною сферою виростання таких слів $є$ найменування осіб за професією. Наприклад: помічник режисера - помреж, начальник медичної служби - начмед, військовий кореспондент - військкор, начальник дивізії-начдив, командир ескадрону - комеск.

У формуванні цієї групи новотворів спостерігається активність певних формантів. Так, досить частотним $є$ елемент зав- (завідувач автогаража - завгар, завідувач лабораторії - завлаб, завідувач літературною частиною - завліт, завідувач організаційного відділу - заворг). Деякі з поскладових абревіатур містять словотворчий елемент держ- (Державний комітет Украӥни по земельних ресурсах - держкомзем, Державний комітет статистики Украйни - 
держкомстат, державне страхування - держстрах) та -ком, що стоїть в постпозиції (репертуарний комітет - репертком, изентральна виборча комісія центрвиборчком, фабрично-заводський місцевий комітет - фабзавмісцевком).

\subsubsection{5. Інноваційні композиційні утворення в лексичній системі СУМ-20}

Композиція як регулярний словотворчий процес також $є$ активним джерелом збагачення лексичного складу сучасної мови. Цей спосіб деривації представляє інноваційні одиниці, що з'явилися внаслідок поєднання основ із вільних словосполучень та за аналогією (основоскладання). «Композити виникають переважно на грунті словосполучень, але порівняно 3 ними $\epsilon$ ціліснооформленими номінативними одиницями, порядок розташування компонентів яких майже завжди сталий» ${ }^{81}$. Утворення номінативних одиниць шляхом словотворчих моделей основоскладання являють собою одиниці, в яких основи здебільшого поєднані сполучними голосними о, е та и.

Дослідження функціонування основоскладання у системі СУМ-20 показало, що серед іменникових інноваційних складних утворень композити представлені меншою кількістю, вони поступаються неологізмам, що виникли шляхом юкстапозиції та абревіації. У процесі появи таких слів найбільшої активності набув спосіб творення 3 вільних словосполучень (шляхом основоскладання, як правило, з суфіксацією). Відзначимо, що найчастотнішими 3 них є одиниці 3 першою іменниковою та другою дієслівною основою, утворені на основі об'єктної синтаксичної конструкції, до складу якої входить опорне дієслово недоконаного виду із залежним іменником (перевозити вантаж - вантажоперевезення, давати вексель - векселедавець, любити чай чаєлюб).

Спостерігається значне поповнення лексичного складу мови іменниковими композиційними одиницями на позначення осіб за певною професією, видом занять, посадою, рисами характеру, рідко - пристроїв та

${ }^{81}$ Українська мова: Енциклопедія / [редкол.: О. О. Тараненко, М. П. Зяблюк та ін.]. К. : Укр. енцикл., 2004. С. 24. 
апаратів. Серед словотвірних типів, що послужили творенню нових композитів, виявлено такі: із суфіксом -ач (авансотримач, авансоутримувач, векселетримач, бактеріовловлювач, зискоотримувач, бензиновловлювач, бочконавантажувач), із суфіксом -ець (вазописещъь, авансодавещъь, грошодавецьь, законотворецьь), із суфіксом -ник (вагонобудівник, вантажсоласник, податкоплатник).

У композитному творенні іменників активними стали компоненти українського походження. Зокрема, це постпозитивні словотворчі форманти: -творення (бюджетоутворення, вуглетворення, газоутворення, законотворення, державотворення, міфотворення, рельєфоутворення, термінотворення, текстотворення), -люб (владолюб, женолюб, сонцелюб, тваринолюб, чарколюб), -давець (заставодавец̧ь, наймодавецьь, орендодавецьь, лізингодавещ̧ь, грошодавецьь).

Дослідження механізму утворення нових дериватів показало, що СУМ-20, який репрезентує лексичний склад української мовної системи, відображає активні процеси утворення іменникових номінацій. Розширенню лексичного діапазону мови сприяли різні словотворчі моделі субстантивів. При цьому найпродуктивнішими словотвірними процесами виявилася суфіксація, юкстапозиція та абревіація. Значну активність при творенні нових слів виявили як словотворчі форманти української мови, так і елементи іншомовного походження.

Виникнення іменникових неологізмів засвідчує тісний зв’язок мови 3 життям соціуму, роль позалінгвістичних чинників у динаміці лексикосемантичної системи української мови, під впливом яких розвинулись певні тематичні групи лексики. В результаті аналізу виявлено, що найактивніше поповнили словниковий склад української мови іменникові неологізми, представлені у СУМ-20, які репрезентують суспільну, політичноадміністративну, юридичну, фінансово-економічну, інформаційну лексику, а також слова, що функціонують у різних галузях знань, зокрема медицині, біології, фізиці, хімії. Як демонструє матеріал СУМ-20, утворення нових 
іменників $є$ активним та продуктивним процесом у постійному і безперервному поповненні словникового складу української мови.

\subsection{3. Словотворення прикметникових інновацій}

\subsubsection{1. Суфіксальний словотвір прикметників}

Значну роль у поповненні словникового складу української мови неологічними входженнями відіграють прикметники, які посідають після іменників друге за чисельністю місце серед словотвірних інновацій. Ця тенденція спостерігається в різні періоди розвитку мови. Прикметники створюються не так активно, як іменники. І це цілком природно. Світ предметів весь час поповнюється новими позначеннями, у той час як світ ознак не росте так швидко. Збагачення лексики за рахунок нових прикметникових утворень досить відчутно позначилось на збільшенні реєстру СУМ-20.

Утворення прикметникових неологізмів зумовлене перш за все потребами вербалізації різних ознак, властивостей, якостей об’єктів, явищ, процесів тощо. Крім того, поява нових іменникових найменувань вимагає породження відповідних означень, оскільки номінативна функція прикметників реалізується через поєднання з іменниками - назвами предметів, які мають певні ознаки.

Велика кількість інноваційних прикметників твориться також на основі власного словотворчого матеріалу, що в українській дериватології представлений великим словотвірним масивом. Активним чинником творення нових прикметників $є$ значне поповнення лексичного складу української мови запозиченнями, адже аналізована доба характеризується появою великої кількості іншомовних слів. Таким чином, інноваційні прикметникові утворення постають як на власне українському грунті, так і на запозиченому словотворчому матеріалі.

Сучасний період розвитку лексики характеризується активною появою нових прикметників-дериватів. Корпус прикметникових неологізмів, утворених шляхом словотворення, у СУМі становить, за нашими підрахунками, більше 8500 лексичних одиниць. 
Дериваційні прикметникові неологізми утворені переважно суфіксальним, префіксально-суфіксальним, префіксальним способами, а також за допомогою композиції, нечисельними є інноваційні одиниці, що виникли в результаті юкстапозиції.

Розглянемо дериваційні неологізми, представлені в 20-томному СУМі, утворені суфіксальним способом. Новотвори цього типу, як і в описаному вище класі іменників, становлять основний масив прикметникових утворень. Цей факт підтверджують і дослідження мовознавців. Так, М. М. Шанський у своїй роботі, присвяченій словотвору, зазначав, що суфікси прослідковуються як активні твірні морфеми у всіх продуктивних категоріях слів.

Найбільш регулярно і послідовно прикметники творяться від іменникових основ (авантюрин - авантюриновий, адоптація - адоптивний, дистонія дистонічний, депозит - депозитарний тощо. Проте збагачення лексичного фонду прикметниковими неологізмами не обмежене лише відіменниковими утвореннями, матеріал засвідчує нові прикметникові деривати, що постали на основі дієслівних та прикметникових мотиваторів: втішливий, залесливий, хоробренький, легшенький.

Специфіка дериваційних процесів у сфері прикметників перебуває у безпосередньому зв'язку з їх класифікаційним поділом на дві відмінні 3 функціонального погляду групи - відносні та якісні. Особливості цього зв'язку виявляються насамперед у тому, «...що кожному відносному прикметникові обов'язково властива двочленна внутрішньоструктурна організація, яка полягає у взаємодії твірної основи (іменникової, дієслівної, прислівникової тощо) і дериваційного суфікса. Щодо відносних прикметників неможливе виключення структурної (обов'язкова наявність словотворчого суфікса) і функціональносемантичної (вираження ознаки через відношення) характеристик. Група якісних прикметників неоднорідна з цього погляду, тому що хронологічно найдавніший ï шар становлять позначені відсутністю суфіксальних морфем лексичні одиниці, у структурі яких з синхронного погляду можливе виділення тільки основи (як правило співвідносної з кореневою морфемою) і закінчення 
(словозмінної морфеми)» 82 . Таким чином, поділ прикметників на відносні та якісні взято за основу при розгляді словотвірних моделей прикметникових інновацій.

У результаті аналізу мовного матеріалу виявлено, що велику групу новоутворень складають відносні прикметники. Прикметники на позначення відносності, на відміну від якісних, виражають ознаку предмета як властивість, що випливає з його зв'язків або відношень з іншими предметами, явищами чи процесами позамовної дійсності ${ }^{83}$. Основний масив нових відносних прикметників мотивований іменниковими основами. Переважна кількість прикметникових інновацій сформована на основі власної мовної бази. Значну роль відіграли також іншомовні форманти, які послужили поповненню прикметників цього класу новими лексемами.

Реєстр нового Словника поповнився також словами на позначення релігійних понять, зокрема церковних рухів: екуменічний, євангелістичний.

У загальному потоці новотворів помітну групу становлять відносні прикметники, утворені за допомогою суфікса -арн- (-ярн-), мотивовані іменниковими основами чоловічого роду 3 кінцевим приголосним та жіночого роду на -а (-я): барний, вівчарний, гітарний, елітарний, компліментарний.

У межах відносних відіменникових прикметників з’явився ряд слів, утворених за допомогою суфікса -ивн-. Найширше тут представлені прикметникові похідні, співвідносні з іменниками жіночого роду на -ія, а саме: адоптивниц̆, адвентивний, а також похідні, співвідносні 3 іменниками чоловічого роду, що мають нульову флексію, наприклад: ад’єктивний, абсолютивний.

Значною продуктивністю відзначається тип словотворення зі значенням загальної відносності, що містить словотворчий формант -ов-. За допомогою цієї моделі утворюються слова, що формують лексичні одиниці готівковий,

${ }^{82}$ Словотвір сучасної української літературної мови / [за ред. М. А. Жовтобрюха]. К. : Наук. думка, 1979. С. 119.

83 Українська мова: Енциклопедія / [редкол.: О. О. Тараненко, М. П. Зяблюк та ін.]. К. : Укр. енцикл., 2004. С. 527. 
горщиковиц̆, графиновий, брелковиц̆, ганчірковий, барвінковиц̆, барвниковиц̆, бичковий, буйковий та ін.

Порівняно менше виникло прикметників із словотворчим формантом -ев(-св-) на позначення матеріально-речовинних відносних прикметників: мазевици, гривневий, иявілевий, тербієвий. Він виявляє свою продуктивність звичайно при утворенні відносних прикметників, мотивованих іменниковою основою зі значенням речовини, матеріалу.

Окрему групу слів із матеріально-речовинним значенням із суфіксом -ндемонструють одиниці, мотивовані основами на позначення відношення до різних речовин та предметів: тканини (атласний, шифонний, котонний), їжі (кавний, ліверний) та рослин (хмизний, щяавельний).

У межах прикметників з матеріально-речовинною семантикою незначна кількість лексем утворена за допомогою словотворчих формантів -ов-: ватиновий, джинсовий, джерсовий та -ів-: грейпфрутів, йогуртів.

Окрему групу відносних прикметників складають похідні, мотивовані різними найменуваннями людей. При утворенні зазначеної групи відносних прикметників найбільша активність виявлена у суфікса -ськ- (-цьк-). У реєстрі Тлумачного словника представлені такі відіменникові лексеми, як абітурієнтський, активістський, вуайєристський, байкерський, барахольницький (розм.), парламентський, апостолівський, адвентиський, аболічіоністський, абсурдистський, авангардистський. Значну групу новотворів являють прикметники, що походять від імен та прізвищ відомих людей: шевченківський, шашкевичівський, уелсівський, макіавеллівський, наполеонівський.

Відіменникові прикметникові новотвори, утворені за допомогою форманта -ськ- (-цьк-), представляють також лексику стосовно професійної зайнятості особи: аудиторський, брокерський, вахмістерський, вахтерський, рієлторський, спікерський. Цей суфікс служить також творенню відтопонімічних прикметників: грецьький, троӥиький, нюрнберзький.

Інша словотворча морфема, що відноситься до цієї ж групи найменувань, - суфікс -ач- (-яч-). Твірними основами при цьому виступають іменники - найменування як людей, так і тварин: чумачий, паруб'ячий, 
пацุанячий, щурячий, бугаячий, буйволячиц̆, голуб'ячий, гав'ячий, цุап'ячий, пеліканячий, ящурячий.

Деривати $з$ морфемою -уват- (-юват-) також займають значне місце серед прикметників, що з'явилися в СУМі. Цей словотвірний тип виражає такі значення: «схильний до вияву ознак (рис характеру, поведінки, стану тощо) відповідно до значення мотивуючого іменника» (бомжуватий, гадюкуватий, хробакуватий, кугутуватий, бугайкуватий, босякуватий, глинуватий); «подібний за формою до названого мотивуючим іменником» (горошкуватий, глечикуватий, ковпакуватий).

Велика кількість прикметників утворена за допомогою суфіксів -ат-, -чат-, -ав-, що мають словотвірне значення «такий, що характеризується наявністю чого-небудь, має що-небудь» і «такий, що має що-небудь у великій кількості, наділений чим-небудь надміру». Лексеми цього типу переважно характеризують зовнішність особи (пасматий, щуелепатий, черевчатий, пальчатий).

У новому Словнику зафіксовано меншу кількість відносних прикметникових інновацій, які мають віддієслівне походження. При їх творенні задіяно словотворчий формант -альн-: балансувальний, брикетувальний, буксирувальний, бромувальний.

Одним із засобів формування нових слів служить формант -к-, що приєднується до дієслівної основи. Як правило, це одиниці на позначення зовнішніх та внутрішніх ознак людей та предметів: тремкий, тряский, хвалкий, хлюпкий.

Не менш продуктивним виявився тип словотворення, що містить компонент -лив-, який поєднується 3 дієслівними основами, частина яких ускладнена префіксальними морфемами. Ці лексеми служать для найменування характеру, вдачі, рис людини (влюбливий, вслужливиц̆, втомливий, зрадливий, лагодливици, вкрадливий).

Поповнення словникового складу української літературної мови відбувається також за рахунок якісних прикметників, які значно поступаються в кількісному відношенні відносним. Вони представлені відприкметниковими похідними, які утворені за допомогою суфіксальних формантів. 
Серед продуктивних словотвірних типів, що виникли внаслідок суфіксації, $\epsilon$ якісні прикметники з твірною прикметниковою основою, які складають досить значну групу. У Словнику представлені різноманітні моделі таких утворень. Серед прикметникових інновацій кількісно виділяються похідні із суфіксами -еньк(тяжкенький, голосненький, щедренький, каренький, приязненький, чудненький), -есеньк- (свіжесенький, темнесенький, холоднесенький, червонесенький), -ісіньк(вірнісінький, давнісінький, жоднісінький, рябісінький, синісінький, ситісінький), менше утворень із суфіксами -усіньк- (-юсіньк-) (маніпусінький, худюсінький), що використовуються для вираження посиленого або зменшеного порівняно 3 нейтральним ступенем вияву ознаки.

Крім того, з’явилися нові лексичні одиниці, які містять суфікси -ющ-, -юч-, -ящ- (густющий, ситющиий, смачнющчий, складнющий, вреднючий, пахнючий, усевидящий, ясновидящий). Ці лексеми поповнити групу слів на позначення посиленого вияву ознаки.

\subsubsection{2. Префіксально-суфіксальний словотвір прикметників}

Серед афіксальних способів творення прикметників вагоме місце займає префіксально-суфіксальний словотвір. При префіксально-суфіксальному способі словотворення, як зазначають дослідники, «префікс та суфікс, виступаючи як твірні елементи одночасно, являють собою дистантну біморфему» $^{84}$. Цей словотвірний тип набув широкого застосування при формуванні прикметникових інновацій, що значно розширило межі лексичного фонду української мови. Аналізуючи функціональну роль цих словотворчих елементів у мовній системі, Н. Ф. Клименко пише, що «Фундамент словотворення нашої мови тримається на префіксах та суфіксах... Багатство цього інвентаря одиниць у тому, що ми можемо безліч разів по-різному комбінувати елементи, одержуючи подібні і відмінні слова. Комбінації морфем теж є відносно сталими і повторюваними» ${ }^{85}$.

${ }^{84}$ Мельчук И. А. О внутренних флексиях в индоевропейских и семитских языках. Вопр. языкознания. 1963. № 4. С. 34.

${ }^{85}$ Клименко Н. Ф. Як народжується слово. К. : Рад. школа, 1991. С. 54-56. 
Група префіксально-суфіксальних неологізмів являє собою прикметникові одиниці, утворені на базі сполучень прийменників та іменників, а також окремих іменникових та дієслівних основ із часткою не. У прикметникових новотворах прийменники та частка не виступають як префікси. Коли прийменник (так само і частка) зливається з іншою частиною мови, утворюючи нове слово, він остаточно втрачає свою лексичну відокремленість, перетворюючись на словотворчий формант - префікс. Значний масив нових прикметників представлений лексемами, що утворені від прийменниковоіменникових сполучень. Ці мовні одиниці у своєму складі мають іменникову основу, префікси-прийменники та суфікси. Таким чином, у сучасній українській мові з'явилася велика кількість відносних прикметників, якісних прикметників зафіксовано небагато.

Дослідження лексичного складу свідчить, що словотворчий матеріал, який послужив творенню нових прикметникових лексем цього типу, представляе велику кількість словотворчих формантів, які мають різну словотвірну та лексичну семантику. Зазначимо, що проаналізований матеріал демонструє, що при творенні нових прикметникових лексем помітно вирізняються своєю активністю префікси без- та проти- і ті суфікси, які використовуються разом з цими словотворчими формантами.

Так, Словник у 20-ти томах збагатився новими прикметниками, утвореними від іменникових основ за допомогою префікса без- і суфіксів -н-, -ов-, -овн-, -льн-. Вони мають словотвірне значення «такий, що не має або позбавлений чогось». Помітну роль у поповненні лексичного складу мови відіграє словотвірний тип із префіксом без- та суфіксом -н-: безальтернативний, безвартісний, безмаштабний, бездетонаиійний.

Серед прикметникових відіменникових дериватів менш продуктивними $€$ одиниці, в основу яких ліг словотвірний тип з префіксом без- та суфіксом -ов-. Тут можна виділити слова на позначення понять фінансової сфери, які $є$ найчастотнішими: безвідсотковий, безавансовий, безвізовий. Технічна галузь поповнилася такими новими вербальними одиницями, як безстиковий, безперевалковий. 
Група слів із префіксом без- та суфіксом -льн- представляє лексичні одиниці, пов’язані 3 технічною галуззю: безкабельний, безавтомобільний, безканальний.

Невелику кількість нових утворень продукує словотвірний тип із префіксом без- та суфіксом -овн-, що функціонують як загальновживані лексеми: безгрунтовний, бездуховний, безосновний.

Відзначимо, що одними 3 найвагоміших серед досліджуваних інноваційних утворень є нові прикметники із префіксом проти- та суфіксами -н-, -ов-, -ськ-, -цьк-, -альн-, -ичн-, -уч-, -ист-, які утворені від іменникових основ та мають словотвірне значення «призначений для боротьби 3 чимось», «скерований проти чогось».

Використання словотвірних моделей із префіксом проти- та відповідними суфіксами розширило лексичну групу слів, які характеризують засоби, направлені проти шкідливої дії природних стихій: протиобвальний, протилавинний, протизаймистий, протидимний, протиметеоритний, протипиловий, протисонячний, протитуманний, протикорозійний. Зафіксовано прикметникові лексеми, що характеризують актуальні для певного історичного періоду та суспільно-політичного життя країни поняття: протигромадський, протизагарбницький, протиконструктивний, протинародний, протипанський, протиправний, протиреволющійний, протисвященницький, протисуспільний. Також з’явилися нові слова у військовій лексиці: протиснарядовий, протилітаковий, протиракетний, противибуховий.

Значну моделюючу силу має дериваційний тип 3 префіксом перед- та суфіксами н-, -ов-, -ян-, -ічн-, -альн-, словотвірні значення якого: «такий, що в часі передує чомусь або відбувається раніше від того, на що вказує основа твірного іменника» (передзмагальний, передрейсовий, передпроектний, переддошкільний, передпенсійний, передстаречий, передобідній, передноворічний, передстароноворічний).

Інша група афіксів, яка відзначається меншою продуктивністю, також послужила дериваційним матеріалом для появи нових прикметників. Префікс на- та суфікси -н- та -ов- лягли в основу творення одиниць із загальним 
словотвірним значенням «такий, що знаходиться або призначений знаходитися на предметі, названому твірною іменниковою основою». Інновації цього типу пов’язані 3 частинами тіла людини або тварини (наголовний, нашийний, намордний), а також такі, що іменують стосунок до предметів (намісний, натронний).

Провідне місце у поповненні Словника новими лексичними одиницями займають новотвори, які означають місце перебування когось або чогось. Серед них певна кількість префіксально-суфіксальних відіменникових прикметників утворена за допомогою словотвірного типу - префікса при- та суфіксів -н-, -ов-. За їх участю формується значення «такий, що простягається понад чимось або знаходиться поблизу чого-небудь». Тут, як правило, представлена лексика, яка називає ознаки, пов’язані 3 будівлею: пристінковий, притерасний, придверний, а також та, що означає розташування біля чогось: прииосейний, припортовий, приканальний.

Реєстр Тлумачного словника розширився також за рахунок прикметників iз моделлю словотворення, що містить форманти за- та -н-, -ов- та виражає значення «такий, що знаходиться, виникає, відбувається там, де визначено твірною основою». До цього типу належать, наприклад, такі дериваційні утворення: загоризонтний, замежовий, закадровий, заквартальний, що становлять переважно загальновживану лексику.

Невеликою кількістю лексем представлені в Словнику в 20-ти томах інші словотвірні префіксально-суфіксальні утворення. Такими є моделі, що мають префікси навколо- та суфікси -н-, -ов- iз словотвірним значенням місця: «такий, що оточує колом названий твірною основою предмет»: навколозубий, навколососковиц̆, навколополярний. Прикметникові утворення 3 префіксом підта суфіксами -н-, -ов- виражають значення «такий, що знаходиться нижче предмета або місця, названого основою твірного іменника»: підстильний, підсупутниковий.

Малопродуктивними виявилися прикметники iз префіксом понад- та суфіксами -н-, -ов-, -янськ- із семантикою «такий, що знаходиться зверху чогось», утворені від основ іменників (понадгірний, понадморський, 
понаддніпровий, понаддніпрянський) і «такий, що виходить за певні межі» (понадпартійний, понадпланетний, понадитатний, понадлюдський).

У досліджуваному мовному матеріалі зустрічаємо також прикметники, семантика яких вживається на позначення часових меж. Серед них назвемо дериваційні неологізми, утворені за допомогою префікса по- та суфіксів -н-, -ов, із словотвірним значеннями «такий, що настав чи відбувся після певної події або якогось періоду, явища» (поопераційний, пожовтневий, попроцесний) і «такий, що відбувається, проводиться там, де визначено твірною іменниковою основою» (покаскадний, поквартирний, пооб'єктний). Загалом цей тип словотворення має незначну продуктивність.

Значно менше одиниць представлено прикметниками із префіксом до- і суфіксами -ов-, -ськ-, що мають значення «такий, що передує в часі певній події, явищу». Це переважно слова, пов'язані з медициною: дородовий, допологовий, долікарський.

Реєстр СУМ-20 розширився також за рахунок нових прикметникових лексем, мотивованих дієслівними основами доконаного виду та основами іменників. Дериваційні елементи словотвірної системи української мови представляють тут частка-префікс не- та різні суфікси.

Префіксально-суфіксальні прикметникові деривати кількісно розширилися завдяки префіксу не-, суфіксам -н-, -анн-, -енн-, -м-, -уч-, -ущ-, -лив-. Модель є продуктивною завдяки активно використовуваному в мові словотвірному значенню «заперечення того, що позначається твірною основою» (неаристократичний, неаргументований, неактивований, небезгрішний). Слід зазначити, що віддієслівні прикметники 3 формантом не- вживаються на означення різних об'єктів і, відповідно, мають різну лексичну семантику. Велику кількість одиниць представляють слова для передачі рис людей - як позитивних (небайдужий, небездарний, нелицемірний, невтомливий), так і негативних (нерозсудливий, недобросердечний, небезвинний, нетолерантний). Словник поповнився також новими мовними формами на позначення ознак та характеристик процесів, понять та явищ (непрофільний, нерегульований, 
несистематичний, непросвітлений, небезвигідний, невладний, нереалізований, непрофесійний, неперспективний).

\subsubsection{3. Префіксальний спосіб творення прикметників}

У словотворенні нових прикметників вагоме місце займає префіксальний спосіб творення. Одиниці цього способу деривації порівняно 3 описаним явищем суфіксації прикметників представлені меншою, але також значною кількістю словотвірних типів. Спостереження над мовою неологізмів показало, що реєстр Словника української мови в 20-ти томах збільшився за рахунок активізації цілої низки запозичених префіксів, яким належить значне місце у появі дериваційних неологізмів: анти-, супер-, ультра-, пост-, квазі-.

Зазначимо, що в дослідженні процесів неологізації спостерігається відсутність єдиного принципу класифікації препозитивних морфем. В значній мірі це пояснюється «...існуванням різних поглядів на такі поняття, як "префікс" i “перший компонент складного слова”, твірне і складне слово, слово і словосполучення» ${ }^{86}$. Ми йдемо за тією класифікацією, яка подана в теоретичній роботі «Словотвір сучасної української літературної мови» за редакцією М. А. Жовтобрюха ${ }^{87}$ в якій ці компоненти кваліфікуються як префікси.

Значне місце в досліджуваних дериваційних процесах займають іншомовні елементи, які виявили досить високу словотворчу активність. Запозичені морфеми, які виділяються в структурно однотипних словах, отримують властивості словотворчих афіксів, і на їх основі утворюються нові лексеми. «Розглядаючи окреме запозичення, можна звичайно спиратися на аналіз його словотворчої структури в мові-джерелі, але такий розгляд буде носити історико-етимологічний характер і не дасть відповіді на питання про морфемну будову іншомовного слова в мові-позичальнику. Але в тих випадках, коли в мові 3'являється ряд іншомовних слів, в структурі і семантиці яких

${ }^{86}$ Голованова Е. А. Об одном типе препозитивных единиц в современном русском языке // Развитие современного русского языка. М., 1986. С. 164.

${ }^{87}$ Словотвір сучасної української літературної мови / [за ред. М. А. Жовтобрюха]. К. : Наук. думка, 1979. С. 12. 
можна побачити деяку однорідність, виникають умови для морфемного аналізу цих слів вже не з погляду мови-джерела, а у межах морфологічної системи мови-позичальника» ${ }^{88}$. 3 цієї позиції і розглянемо моделі із зазначеними запозиченими формантами - відповідно до системи словотвору української мови.

Спостереження над мовним матеріалом інновацій Словника української мови в 20-ти томах показало, що префіксальні елементи іншомовного походження в різних дериваційних моделях мають різне семантичне наповнення і відповідно служать творенню різних лексико-семантичних груп слів. Так, наприклад, активним елементом сучасної словотвірної системи $є$ префікс анти-. Він служить формуванню семантики, яка заперечує ознаку, виражену мотивуючим прикметником, протиставлена цій ознаці, направлена проти неї.

У реєстрі нового тлумачного Словника спостерігаємо активне зростання прикметникових новотворів із словотворчим елементом ультра-. Цей префікс вживається в прикметниках для вираження крайньої великої або крайньої малої безвідносної міри вияву ознаки. (ультранаціональний, ультрапатріотичний, ультралівий, ультраправий). Частина новотворів цього типу вживається на позначення кольорів (ультрахолодний, ультрачервоний) та ознак (ультрамодерний, ультрамодерновий).

На дослідженому матеріалі встановлено, що активністю творення відзначаються прикметники із префіксом супер- на позначення найвищої міри вияву якоїсь ознаки стосовно інших ознак, названих мотивуючими прикметниками. Розширилась група лексики на позначення різних величин: суперважкий, супертонкий, супергігантський. З'явилися також нові словахарактеристики типу супербагатий, суперелітний, суперсучасний, супермодний.

Не менш продуктивним серед препозитивних формантів є словотворчий елемент пост-, що виражає значення «після того, що названо твірною основою». Цей словотвірний тип широко використовується в сучасній українській мові для появи таких номінацій: постмодерністський, постмодерний, пострадянський, постфлораційний, постіндустріальний.

\footnotetext{
${ }^{88}$ Развитие русского языка: Сб. статей Л. П. Крысина. М., 1986. С. 24.
} 


\subsubsection{4. Складні прикметники}

Серед прикметникових інновацій, зафіксованих в Словнику української мови в 20-ти томах, значну частину складають складні форми прикметників. «Кількість прикметникових інновацій значна тому, що вони не тільки використовуються для називання різноманітних, в тому числі й нових ознак, але й тому, що вони входять як конструктивний елемент в дуже поширений клас складених номінацій» ${ }^{89}$.

Нові прикметникові лексеми найчастіше з'являлися в результаті дії словотворчого процесу композиції, менш частотною $є$ юкстапозиція. Активність композитів, як i інших складних новотворів, що виникли в результаті процесу деривації, пояснюється тим, що ці утворення, «...незважаючи на свою громіздкість, складають лексичні групи, семантично i словотворчо зрозумілі всім носіям мови, а тому зручні для наступного утворення за їх зразком інших, подібних слів» ${ }^{90}$.

При творенні інноваційних прикметників опорними виступають сурядні (державно-бюрократичний, земельно-кадастровий, торговельно-економічний, науково-дослідний, навчально-виховний) та підрядні (державотворчий, вовнопрядильний, українознавчий) зв'язки. Перші кількісно переважають другі. За структурою такі утворення є, як правило, двокомпонентними (лічильно-обчислювальний, навчально-консультаційний, селекиійно-генетичний); рідше трикомпонентними (великодержавно-шовіністичний, самодержавно-бюрократичний, лампово-напівпровідниковий).

Розглянемо складні прикметники, утворені на основі сурядного типу зв’язку словосполучень. Як свідчать результати аналізу, істотно поширили корпус прикметників утворення, що виникли внаслідок сполучень двох основ «прикметник + прикметник». Досліджуваний матеріал представляє серед них велику групу складних прикметників на позначення кольорів. Сюди відносяться

89 Земская Е. А. Словообразование как деятельность. М. : Наука, 1992. С. 91.

${ }^{90}$ Кудрявцева Л. А. Моделирование динамики словарного состава языка / [2-е изд.]. К. : ИПЦ «Киевский университет», 2004. С. 154. 
слова на позначення градуювання відтінків (світлих і темних) із словотворчим формантом яскраво- (яскраво-срібний, яскраво-жовтий, яскраво-зелений) та ясно- (ясно-голубий, ясно-жовтий, ясно-фіолетовий). Прикметникові утворення використовується для передачі різних кольорів (чорно-багряний, чорно-фіолетовий, червоно-золотий, синьо-зелений). Зустрічаються також композити асоціативного характеру, де колір одного об’єкта порівнюється 3 кольором іншого: білий, як молоко - молочно-білий, сіруватий, як дим сірувато-димчастий, сіруватий, як попіл-сірувато-попелястий.

У групі складних прикметників на позначення кольорів особливо активними виявились такі словотворчі елементи, як сірувато- (сіруватоблакитний, сірувато-жовтий, сірувато-зелений); синьо- (синьо-зелений, синьозелений, синьо-фіолетовий, синьо-червоний); синювато- (синювато-блакитний, синювато-голубий, синювато-рожевий, синювато-синій); червоно- (чорнобагряний, чорно-жовтий, чорно-рудий, чорно-сизий); чорно- (чорно-синій, чорно-сірий, чорно-фіолетовий, чорно-червоний); зеленаво- (зеленаво-білий, зеленаво-сріблястий, зеленаво-сизий, зеленаво-блідий). Таким чином, прикметники на позначення кольорів та відтінків склали вагомий пласт новоутворених композитів.

Поповнилася новими прикметниковими утвореннями також група суспільно-політичної та загальновживаної лексики. Найбільш продуктивними в таких інноваціях виявилися компоненти соціально- (соиіально-демографічний,

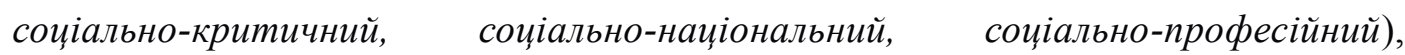
партійно- (партійно-господарський, партійно-державний, партійно-урядовий, партійно-політичний), народно- (народно-визвольний, народно-демократичний), державно- (державно-монополістичний, державно-правовий), службово- (службово-допоміжний, службово-посадовий).

Композитні одиниці використані також для найменування різних понять торгівлі та промисловості. Значна моделююча сила притаманна при цьому формантам торговельно- (торговельно-економічний, торговельнозаготівельний, торговельно-заготовчий, торговельно-збутовий, торговельно- 
кооперативний) та промислово- (промислово-економічний, промисловоекспериментальний, промислово-транспортний, промислово-фінансовий).

Нові складні прикметники використовуються для формування лексики на позначення релігійних течій та напрямків: греко-католищький, греко-православний, римо-католицьький, релігійно-політичний, релігійно-філософський.

Творення композитних прикметників сприяло також поповненню загальновживаної лексики, яка переважно стосується характеристики способів та прийомів подачі інформації: довідково-інформаиійний, рекламно-видавничий, рекламно-інформаційниц̆, рекламно-телевізійний, документально-хронікальний, документально-публіцистичний, сатирико-політичний, детективно-пригодницьький, де активність виявив формант рекламно-.

У Словнику української мови в 20-ти томах спостерігаємо розширення реєстру завдяки поповненню композитів-прикметників, утворених на основі підрядних синтаксичних конструкцій. Істотно поширилися такі утворення на основі атрибутивної конструкції «прикметник + іменник» (високоморальний, різнопрофільний, твердотілий, твердокорий). Менш поширеними є нові композити-прикметники, що постали на основі структур «дієслово + іменник» (алмазогранильний, вовнопрядильний, рудовидобувний, урановмісний, мотороскладальний, монеторозмінний).

Такі складні прикметникові неологізми утворено за певними продуктивними типами, матеріалом для яких стали деякі препозитивні словотворчі компоненти, наприклад: давньо- (давньоболгарський, давньоіталійський, давньоукраӥнський, давньоєврейський, давньоіудейський, давньослов'янський), ново- (новозавітний, новоімперський, новонаставлений, новопосталий, новомодний), високо(високоавтоматизований, високоактивний, високобюджетний, високодисперсний, високоенергетичний, висококомфортабельний), різно- (різнобійний, різномасштабний, різнонаголошений, різнопрофільний, різноспрямований). Серед постпозитивних складників значною словотвірною продуктивністю відзначаються компоненти -бокий (білобокий, кривобокий, однобокий) та -творчий (законотворчий, державотворчий, нормотворчий). 
Отже, основний масив неологізмів, що ввійшов до складу СУМ-20 за рахунок прикметникових утворень, становлять відносні прикметники, менш частотними виявилися якісні. Словник репрезентує значну кількість прикметникових новотворів, де продуктивними $є$ моделі, утворені суфіксальним, префіксальним способом, а також складним способом. Менш активно представлені інновації за префіксально-суфіксальною моделлю. Найбільший масив серед утворених складним способом прикметникових лексем становлять ті, які утворені шляхом композиції. Юкстапозиція використовується для творення незначної кількості прикметникових утворень.

\subsection{4. Дериваційні утворення дієслів}

Порівняно з іменниками та прикметниками дієслівні новотвори в новому Словнику української мови демонструють меншу кількість одиниць. Лексем цього лексико-граматичного класу слів нараховано близько 6500.

Для їхнього творення використовуються переважно такі способи, як суфіксація та префіксація. Крім названих способів деривації, які притаманні також прикметникам та іменникам, дієслівні неологічні утворення виникають також на основі власне дієслівних способів творення: постфіксального, суфіксальнопостфіксального, префіксально-суфіксально-постфіксального. При аналізі нових дієслів до уваги також береться частиномовна належність їхніх твірних основ.

Найбільшою продуктивністю в дієслівному словотворенні сучасної української мови відзначається суфіксальний та префіксальний способи, менш частотними, але також дієвими $є$ префіксально-суфіксальний, суфіксальнопостфіксальний та префіксально-суфіксально-постфіксальний способи.

Переважна більшість нових дієслів у Словнику української мови утворена за допомогою суфіксальних формантів. Суфіксальний словотвір надзвичайно активний при творенні дієслів від основ інших частин мови ${ }^{91}$. Продуктивність суфіксального способу словотворення визначає той факт, що за допомогою

${ }^{91}$ Сучасна українська літературна мова : підруч. [для студ. філол. спец. вузів] / [за ред. А. П. Грищенка. Л. І. Мацько, М. Я. Плющ та ін.] [2-е вид. перероб. і доп.]. К. : Вища шк., 1997. C. 221. 
додавання різних суфіксів до твірних основ утворюються нові слова як того самого, так і іншого лексико-граматичного класу. Як компоненти словотворчої деривації, «Суфікси... виступають в ролі транспортуючого засобу, тобто саме за допомогою суфіксів здійснюється перехід однієї частини мови в іншу» ${ }^{92}$. Саме цей процес спостерігається при творенні дієслів від слів різних частин мови.

Найчисельнішу групу інноваційних одиниць, що виникли внаслідок суфіксації, становлять деривати дієслів іменникового походження. При цьому спостерігається активність словотвірного типу з суфіксом -ува-, що відноситься до власне українських засобів творення. У якості словотворчих значень тут виступають переважно такі: «діяльність, дія чи стан, зміст яких визначається твірною іменниковою основою» (рекет - рекетувати, ксерокопіяксерокопіювати), «бути тим, хто позначений твірною основою» (спонсор спонсорувати, фермер - фермерувати). Як демонструє досліджуваний матеріал, нові лексичні одиниці продукуються переважно від іншомовних слів.

У досліджуваному матеріалі спостерігається продуктивність словотвірного типу із словотворчим елементом -изува- (-ізува-) зі значеннями «забезпечувати чи охоплювати тим, на що вказує твірна основа мотивуючого іменника», та «досягати того або перетворювати в те, на що вказує твірна мотивуюча іменникова основа». Суфікс -изува- (-ізува-) виступає переважно в дієсловах, утворених за допомогою мотивуючих іменникових основ іншомовного походження: максимум - максимізувати, бартер бактеризувати, устандартизувати, актуалізувати, американізувати, урбанізувати, корпоратизувати.

У межах групи відіменникових дієслів виділяється словотвірний тип із суфіксом -фікува-, що виражає значення «здійснювати те, на що вказує твірна основа мотивуючого іменника» та суфіксом -ствува-, який означає «перебувати в якомусь стані, займатися якоюсь діяльністю без відношення до об'єкта». Ці дієслова формують лексику сфери професійної діяльності особи (бригадирствувати, учительствувати, членствувати).

\footnotetext{
${ }^{92}$ Кубрякова Е. С. Что такое словообразование. М.: Наука, 1965. С. 69.
} 
Значну кількість дієслів поряд із суфіксальним способом творення становлять одиниці, утворені за допомогою префіксів. У ролі дієслівних префіксів у сучасній українській мові виступає більшість прийменників. Безумовно, значення префікса безпосередньо пов'язане із семантикою прийменників, які в процесі словотвору виступають у ролі вихідних елементів. Однак специфіка семантичного оформлення залежна і від твірної основи, до якої приєднується префікс. «За межами безпосередніх видових пар дієслівні префікси служать для надання словам найрізноманітніших відтінків як споріднених із значеннями прийменників, так і дуже віддалених від них, причому дуже часто різні відмінності у значенні того чи іншого префікса залежать від семантики кореня чи початкової основи, до якої приєднується даний префікс, а іноді й від характеру суфікса, наявного в початковій основі ${ }^{93}$. Таким чином, префікси виступають важливими конкретизаторами значення дієслівних дериватів. Нові дієслова, що творяться за допомогою префіксальних формантів, не виражають нового типу дії. Вони означають ту ж саму дію, що й дієслова, від яких вони утворені. Префікси, в свою чергу, в процесі словотворення дієслівних одиниць «...конкретизують, уточнюють ці дії в просторовому, часовому, кількісному відношеннях» ${ }^{94}$.

Серед дієслівних префіксів (в основному співвідносних 3 прийменниками), що послужили словотворчими формантами в процесі виникнення новоутворень, продуктивними є такі: в- (у-), від-, при-, пере-, на-, недо-, ре-, де-.

У межах дієслівних неологізмів найпродуктивнішим словотвірним типом $\epsilon$ тип словотворення із власне українським префіксом в- (y-), що виступає носієм часових та просторових значень. Дієслова, що належать до аналізованої моделі, мотивовані цією ж лексико-граматичною категорією слів. Утворені неологізми представляють переважно загальновживану лексику: вмолоти, впекти, втрясти, встерегти, уволокти, угризти, ускубти, деякі 3 них вживаються в розмовному стилі.

\footnotetext{
${ }^{93}$ Ільїн В. С. Префікси в сучасній українській мові. К., 1953. С. 13.

94 Тихонов А. Н. Словообразовательный словарь русского языка. М. : Рус. язык, 1990. С. 22.
} 
Слід додати, що префікс в- (у-) є одним із найдавніших за похоженням дієслівних префіксів української мови, він активно використовується у мовній системі і «має досить різноманітні відтінки у своєму значенні» ${ }^{95}$. Очевидно, тому він $є$ компонентом багатьох словотвірних типів: префіксальносуфіксального (вбалакувати, вбезпечувати), префіксально-постфіксального (вбавитися, вбілитися), префіксально-суфіксально-постфіксального (вбавлятися, вбільшатися).

Менш активними, але також частотними виявилися префікси від-, що вживається у просторовому значенні, вказуючи на віддалення від об'єкта, протяжність дії у часі: відгнисти, відпекти, відполоти, відтрясти та при- на позначення неповноти вияву дії: припрясти, присохти, пристригти, придути.

Серед нових префіксальних дериватів менш продуктивними $є$ дієслівні утворення iз словотворчими формантами на- та недо-: нанести, напасти, натрясти, натягти, недостерегти, недотягти; морфемами пере(переадресовувати, переакизентувати, перекрасти) та с- (сколоти).

Серед дериваційних дієслівних неологізмів певне місце займають також інноваційні лексеми, що виникли внаслідок префіксально-суфіксального способу творення, які кількісно поступаються префіксальному та суфіксальному. У новому СУМі найпродуктивнішими при цьому $\epsilon$ відіменникові та відприкметникові утворення; дієслівні, числівникові та займенникові твірні основи використовуються значно менше. Префіксальносуфіксальний тип включає такі словотвірні моделі: дієслова 3 префіксом в- (у-) i суфіксом -и- на позначення результату дії, досягнення того, що названо твірною основою (вбезпечувати, убілювати, вщчедряти, удержавлювати); дієслова 3 префіксом в- (у-) і суфіксом -ува-, що виражають значення «робити, проводити щось, досягти того, що названо твірною основою» (вбезпечувати, вбалакувати).

Пласт дієслівної лексики поповнився також за рахунок інновацій, у словотвірній моделі яких присутній постфікс -ся. Ця морфема виконує

95 Ільїн В. С. Префікси в сучасній українській мові. К., 1953. С. 64. 
словотворчу роль в словах, утворених суфіксально-постфіксальним, префіксально-суфіксально-постфіксальним способами. Переважна більшість таких інновацій походить від іменникових українських та запозичених основ. У процесі деривації нових слів за допомогою суфіксально-постфіксального способу до твірної іменникової основи одночасно приєднуються суфікс i постфікс -ся. Серед дієслівних новотворів продуктивним типом словотворення виявилася модель із суфіксом -ува- і постфіксом -ся із словотвірним значенням «здійснювати щось, притаманне тому, що називається твірною основою»: абсолютизуватися, адаптуватися, адоптуватися, бруталізуватися, брикетуватися, структуруватися, політизуватися.

У сучасній українській мові менш продуктивним виступає префіксальносуфіксально-постфіксальний тип творення дієслівних інновацій, які мотивовані іменниковими основами. Вони представлені моделлю: дієслова 3 префіксом в- (у-), суфіксом -ува-, постфіксом -ся, для яких характерне значення «стати тим або набути ознак того, що названо твірною основою» (убезпечуватися, убільшуватися).

За даними дослідження реєстру СУМ-20, дієслова-інновації складають значну частину усіх новотворів. Такі деривати утворені різними способами, переважно суфіксальним, префіксальним, префіксально-суфіксальним. Меншою кількістю представлені дієслівні утворення за допомогою суфіксальнопостфіксального, префіксально-суфіксально-постфіксального способів деривації.

\subsection{5. Дієприкметникові новотвори}

У Словнику української мови в 20-ти томах представлено групу пасивних дієприкметників. Нові дієприкметникові утворення - це група слів, мотивована дієсловами недоконаного i доконаного видів. Вихідними компонентами для утворення дієприкметників цієї групи є діслівні основи та суфікси -н-, -ен(-сн-), -т- (вбільшати - вбільшений, вбезпечити - вбезпечений, вбавляти вбавлений).

Деякі лексеми, що творяться від дієслівних основ, мають пари. Так, від дієслова вбезпечити утворені дієприкметники вбезпечений і паралельно (як 
варіант) вбезпечуваний за допомогою суфікса -ува-. Слід зазначити, що варіативність дієприкметникових неологізмів проявляється і в префіксальних видозмінах. Це стосується передусім синонімічних префіксів в- та у-. Майже всі нові дієприкметники, утворені від дієслів, що містять в мотивуючій основі префікс в-, мають паралельні форми 3 префіксами у- (вбезпечений убезпечений, вбільшений - убільшений, вбавлений - убавлений).

При творенні дієприкметників певної групи зберігаються наслідки тих морфологічних змін, які виникають в основі 1-ої особи однини (зміни приголосних, чергування), наприклад, вберегти - вбережений.

\subsection{6. Прислівникові неологізми}

Дослідження лексичного складу засвідчило, що корпус нових прислівників у новому СУМі, порівняно 3 іншими частиномовними утвореннями - іменниковими, прикметниковими і дієслівними - $є$ невеликим. Прислівникові деривати, представлені в Словнику, становлять переважно одиниці, що виникли внаслідок префіксально-суфіксального способу творення. Слід зазначити, що нові прислівники 20-томного СУМа - це переважно слова, які існували у мові, але не стали складовими реєстру 11 -томного Словника.

Поповнився лексичний склад СУМа прислівниками, утвореними префіксально-суфіксальним способом. Морфеми як словотворчі компоненти переважно мотивовані основами відносних та якісних прикметників із словотворчими елементами по-, -и та -ому, де продуктивним став словотвірний тип з префіксом по- та суфіксом -и на позначення способу дії: по-сестринськи, по-дідівськи (від основ з ознакою свояцтва), по-багацьки, по-бідарськи, по-

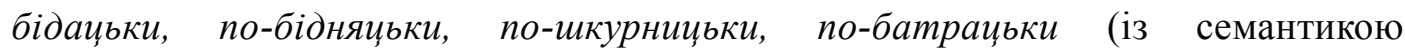
соціального статусу), по-хамськи, по-хуліганськи, по-блазенськи, поблюзнірськи, по-діляц̧ьки, по-крутійськи (утворені від основ, що виражають характеристику особи), по-морящьки, по-митецьки, по-мисливськи (на позначення певної діяльності). 
Значну групу нових прислівників становлять слова на позначення способу дії з формантами по- та -и, мотивовані відтопонімічними прикметниками: по-аргентинськи, по-африканськи, по-балтськи, по-волоськи, по-балтійськи, по-бельгійськи, по-боснійськи, по-в'єтнамськи, по-американськи, по-англосакськи, по-англосаксонськи, по-афганськи, по-арамейськи.

Серед префіксально-суфіксальних інновацій значною активністю відзначається словотвірний тип із морфемами по- та -ому. Цим способом утворені такі одиниці: по-багацькому, по-бідацькому, по-блазнівському, по-дівоцькому, по-діловитому, по-ділящькому, по-епікурейському, по-заморському, по-кампанійському, по-ковбойському, по-космонавтському, по-крутійському, по-купецькому. Зауважимо, що більшість із цих утворень мають паралельні форми із суфіксом -и.

Префіксально-суфіксальним способом утворюються прислівники, які в мовленні існують як варіанти, на основі відносних та якісних прикметників за допомогою словотворчих формантів по- та -и, -ому: по-екстремістськи, по-екстремістському; по-ділячьки, по-діляцькому; по-крутійськи, по-крутійському.

Отже, досліджуваний мовний матеріал засвідчує, що деривація є одним із важливих джерел лексичного збагачення мови. Про це свідчить мовна реальність - велика група словотворчих неологізмів в лексичному складі української мови, представленому в новому тлумачному Словнику у 20-ти томах. Серед різних процесів утворення нових лексичних одиниць саме дериваційна неологізація відіграє ключову роль у розвитку лексичної системи мови.

Зовнішні соціальні чинники є імпульсом для дії словотворчого потенціалу мови, реалізації можливостей, закладених у дериваційній підсистемі. Функціонування словотвору як мікросистеми (у взаємодії і взаємозв'язках іiі елементів), що продукує дериваційні неологізми в лексичну систему мови, дія закону «збереження мовної енергії», тяжіння до словотворчої аналогії тощо є тими внутрішніми мовними чинниками, що виявили свій творчий характер стосовно появи нових дериваційних утворень.

Як свідчить матеріал СУМ-20, найбільшу групу неологізмів становлять іменники, які є мовними репрезентантами великої кількості нових явищ, 
понять, об’єктів, предметів. Іменникові дериваційні утворення кількісно значно переважають неологізми інших лексико-граматичні класів.

Продуктивним процесом у дериваційній неологізації іменників $\epsilon$ суфіксація із використанням таких формантів: -ість (-ність), -ств-, -нн-, -ізм (-изм), -аці- (-яці-), -к-, -иц-. Менш частотними, але також активними виявилися морфеми -ист-, -ник-.

Зазначимо, що реєстр Словника поповнився значною кількістю дериваційних новотворів складного типу. В процесі неологізації складних субстантивів особливо продуктивними були такі типи словотворення, як юкстапозиція та абревіація. Порівняно меншою кількістю представлені нові іменники, утворені шляхом композиції та зрощення.

Слід зазначити, що характерною рисою сучасної дериваційної системи української мови $є$ використання в ролі словотвірних елементів власне українських одиниць: держ-, політ-, госп- (в абревіатурах); -люб, -творення, -давець) (в композитах) та ін., значною продуктивністю відзначаються також іншомовні форманти: гамма-, веб-, медіа-, експрес- (в юкстапозитах); авіа-, авто-, відео- (в зрощеннях); -терапія (в композитах) та ін.

Друге місце в кількісному відношенні серед інновацій посідають прикметники. Неологізми цього типу утворені переважно суфіксальним способом, де активними виявилися форманти -ичн- (-ічн-), -ивн-, -ськ-, -н-, -арн- (-ярн-), -лив-, -уч- (-юч-), -уват- (-юват-), -альн- та префіксальносуфіксальним способом творення, в якому продуктивними є такі словотворчі одиниці: без-, -н-, -ов-, -альн-; проти-, -н-, -ичн- (-ічн-), -ськ-; поза-, -н-, -ов-, -ськ-. Менш задіяним в процесі творення прикметників виявився префіксальний спосіб, де використовуються префікси анти-, ультра-, супер-, пост-.

Значною кількістю представлені в Словнику складні прикметникові утворення, де продуктивним типом словотворення виявилася композиція, менш активною - юкстапозиція. Абревіація та зрощення виявилися непродуктивними моделями словотворення. Для словотвору складних прикметників характерні такі елементи: науково-, теоретико-, рекламно-, селекційно-, радіаційно-, 
народно-, державно-, високо-, -творчий, промислово- (в композитах), соціал-, віце- (в юкстапозитах).

Меншу за обсягом групу, порівняно з іменниковими та прикметниковими неологізмами, становлять дієслова. Серед дієслівних інновацій продуктивними виявилися утворення, що виникли внаслідок суфіксації, зокрема з суфіксами -ува-, -изува- (-ізува-) та -фікува-, а також префіксації, де переважна більшість слів утворена за допомогою формантів (в-) у-, від-, при-, ре-, де-. Меншою кількістю представлені дієслівні новотвори, що з’явилися у результаті префіксально-суфіксального способу із словотворчими формантами (в-) у-, -ува-; у- (в-), -и-. Невелику продуктивність в утворенні дієслів виявили суфіксально-постфіксальний, префіксально-суфіксально-постфіксальний способи.

Нових дієприкметникових та прислівникових лексем зафіксована невелика кількість.

Отже, матеріал нового тлумачного Словника української мови засвідчує інтенсивні явища неологізації їі лексичного складу, зокрема, з використанням потенційних можливостей словотворення, завдяки чому мова реалізує свої можливості у забезпеченні комунікативних потреб суспільства. Завдяки словотворчим процесам, що продукують появу дериваційних новотворів, словниковий склад української мови постійно збагачує свої ресурси та розширює межі свого функціонування.

\section{3. Семантичні неологізми в лексичній системі української мови}

\subsection{1.Семантичні процеси як один із шляхів збагачення лексики української мови}

Важливу складову частину реєстрових одиниць (більше 35 тис. інновацій) Словника української мови в 20-ти томах становить велика кількість нових явищ, обумовлених зміною семантичної структури слів. У досліджуваний період (кінець XX - початок XXI ст.) значне поширення знайшла тенденція до збагачення складу лексики через появу лексико-семантичних новотворів, які 
виникли в результаті модифікації значення наявних у мові слів. Потреба у нових найменуваннях фактів різних сфер життєдіяльності людини, бажання не лише назвати якийсь предмет, явище, подію, але й дати йому експресивну оцінку, пошуки термінологічних позначень і т. п. - усе це привело до утворення нових семантичних неологізмів.

До вивчення питання семантичної еволюції слів зверталося багато українських та зарубіжних дослідників: Ю. Д. Апресян, Р. О. Будагов, Л. О. Кудрявцева, Л. А. Лисиченко, О. Г. Муромцева, Ж. П. Соколовська, Ю. С. Сорокін, Ф. П. Філін, Д. М. Шмельов та ін. На сучасному етапі розвитку мови в україністиці семантичні інновації вивчають такі вчені, як Т. О. Бевз, М. П. Кочерган, О. А. Мітчук, Д. В. Мазурик, І. А. Самойлова, О. А. Стишов, О. О. Тараненко та ін. Проте величезне число нових явищ, зафіксованих у реєстрі нового СУМа, потребує встановлення закономірностей оновлення та збагачення словникового складу, представленого цією лексикографічною системою. Динамічний характер семантичного розвитку слова виявляється в розширенні або звуженні, узагальненні чи конкретизації, уточненні твірного значення.

Реагуючи на такі вимоги суспільства, як актуальність та стійкість, різноманітність та уніфікованість, економність та багатство, мова постійно змінюється і вдосконалюється: «Свідомий тиск суспільства на розвиток мови проходить шляхом зміни соціальної функції лінгвеми і цілеспрямованого пристосування iï до функціонального навантаження в цьому суспільстві» ${ }^{96}$.

Серед ряду факторів, що впливають на семантичну динаміку мовної системи, значну роль відіграє ряд процесів, серед яких вагоме значення має демократизація суспільства. Вона дала поштовх вагомим перетворенням у житті соціуму і, як наслідок, появі значної кількості нових слів та значень. Не менш визначальним для зазначених процесів є стрімкий науково-технічний прогрес, який сприяв появі нових семантичних одиниць в лексиці.

96 Журавлев В. К. Внешние и внутренние факторы языковой эволюции. М. : Наука, 1989. C. 136 . 
При цьому дія суспільного фактора вивчається в органічному зв'язку з внутрішніми законами мови, оскільки, як зазначають дослідники, «..якими б численними не були приклади реакції лексико-семантичної системи української мови на “соціальне замовлення”... визначальними факторами семантичного розвитку залишалися причини внутрішнього характеру, що лежать в основі саморозвитку мови» ${ }^{97}$. Розвиток лексико-семантичної системи відбувається за певними закономірностями, пов'язаними 3 іiі організацією. До внутрішніх факторів лексичної динаміки відносять мовні антиномії - ті закони, яким підпорядкована система мови. Саме ці мовні антиномії приводять до зміни в семантиці слова, розширення меж його значеннєвого функціонування. «Джерелом еволюції, - за словами В. М. Русанівського, - $\epsilon$ ті суперечності, які виникають між значенням слова (сукупність його семем) і його значимістю (синтагматичними можливостями), а внаслідок цього через постійне напруження рівноваги іiі [лексичної системи] компонентів» ${ }^{98}$.

Внутрішньомовні фактори пов'язані з самою будовою та організацією лексичної системи. Мова оперує своїми можливостями для постійного удосконалення та розвитку лексичних ресурсів. У будові мови закладені великі потенційні можливості оновлення власних засобів - це природна особливість їі існування, один із базових процесів, на яку спирається лінгвальна динаміка, що «...співвідносна з принципом виведення одних одиниць із інших, із мовною відтворюваністю (похідністю), перетворенням, трансформацією, модифікацією мовного знака... Збагачення словникового складу постійно відбувається за рахунок семантичного варіювання слів, що $є$ їх органічною та постійною властивістю» ${ }^{99}$.

${ }^{97}$ Муромцева О.Г. Про деякі активні процеси в словниковому складі української літературної мови кінця 80-90-х років XX ст. // Украӥнська мова: з минулого в майбутнє : матеріали наук. конференції. К., 1998. С. 115-116.

98 Русанівський В. М. Структура лексичної і граматичної семантики. К. : Наук. думка, 1988. C. 62.

${ }^{99}$ Кузнецова Э. Г. Лексикология русского языка: учеб. [пособие для филол. фак. ун-тов] [2-е изд., испр. и доп.]. М. : Высш. шк., 1989. С. 9. 
Семантичні явища, що постійно відбуваються в мовній системі, $\epsilon$ незамінним фактором комунікативних процесів. Поява нових значень у багатьох є одним із важливих засобів організації лексичного складу мови, щоб забезпечити ii функціонування, інакше довелося б для кожного нового найменування утворювати нове слово. «Жодна мова не була б спроможна виражати кожну конкретну ідею самостійним словом або кореневим елементом. Конкретність досвіду безмежна, ресурси найбагатшої мови суворо обмежені» 100 .

Аналізуючи внутрішньомовні причини модифікацій лексичних значень, дослідники підкреслюють роль таких факторів, як особливості структури слова та його синтагматичні можливості, що «...обумовлені внутрішньомовними відношеннями, їхньою здатністю до різного роду переміщень і трансформацій. Семантична структура багатозначного слова, тобто відношення між різними його значеннями, залежить від внутрішньомовних зв'язків слова і в свою чергу визначає ці зв'язки, що $\epsilon$, таким чином, елементом власне мовної його характеристики» $^{101}$.

Крім цього, поява в слові переносного значення залежить від наявності в значеннєвій структурі внутрішньої семантичної двоплановості, що створює підгрунтя для появи переносних значень. «Оскільки кожне переносне значення є семантично похідним, вторинним, тобто неосновним, воно співвідносне з основним значенням. Переносне значення обов'язково співвідноситься з основним, і ця співвіднесеність створює внутрішню форму значення, обумовлює його семантичну двоплановість» ${ }^{102}$.

На динамічний характер лексичного складу мови, спричиненого різного роду семантичними змінами, впливає також така властивість мовного знака, як асоціативність: «Зі зміною позначуваного у свідомості мовців формуються нові

${ }^{100}$ Виноградов В. В. Стилистический аспект русского словообразования. М. : Наука, 1984. C. 18.

101 Лексика современного русского литературного языка / [под ред. М. В. Панова]. М. : Наука, 1968. С. 96.

${ }^{102}$ Кузнецова Э. Г. Лексикология русского языка: учеб. пособие для филол. фак. ун-тов. [2-е изд., испр. и доп.]. М. : Высш. шк., 1989. С. 110. 
асоціативні зв’язки між словами як фонографічними знаками (матеріальними компонентами) та співвіднесеністю цих слів як мовних знаків 3 одиницями дійсності» ${ }^{103}$. Отже, слово як номінативний знак під впливом різних суспільних змін, впливів на нього, аналогій і суміжних асоціацій може змінювати своє значення.

Механізм перебудови лексичного значення слова, результатом якого є нові лексико-семантичні одиниці в мові, пов'язаний також із законом збереження мовної енергії. Структура полісемічного слова розширюється за рахунок так званого «нанизування» нового змісту на вже існуючу в мові форму, а отже «Багатозначність слова породжується прагненням мови до економності засобів вираження» ${ }^{104}$.

До внутрішньомовних чинників розвитку вторинних значень, крім діючих власних законів динаміки мови, особливостей семантичної структури слова, його здатності до семантичної двоплановості, відносяться також його стилістична належність, функціонування в певних контекстах, сферах вживання, лексична сполучуваність і т. д. «Зрушення в структурі виражальних засобів стилю стосовно загальномовної експресивної бази примушує створювати нові способи вираження суб’єктивного ставлення до описуваного. Нейтралізація виражальних засобів всередині стилю неминуче викликає появу в ньому нових способів досягнення експресивності. До них належать традиційне звернення до живомовної стихії та використання нейтральних засобів інших функціональних стилів» ${ }^{105}$.

Аналізуючи причини появи нових значень слів, у роботі ми спираємося на поняття семантичної структури слова, яка є однією з внутрішньомовних засад формування нових лексичних значень. Слід відзначити, що розуміння лексичного значення як процесу лексико-семантичного варіювання слова i результату цього процесу властиве для системного представлення лексики й дає

103 Мацько Л. Українська мова в кінці ХХ ст. (зміни в лексиці). Дивослово. 2000. № 4. С. 8.

104 Русанівський В. М. Структура лексичної і граматичної семантики. К. : Наук. думка, 1988. C. 71

105 Русанівський В. М. Життя слова / В. М. Русанівський, С. Я. Єрмоленко. К. : Вища шк. при КДУ, 1978. С. 139. 
можливість виділити лексико-семантичний варіант слова й представити структурну організацію смислового змісту багатозначного слова у вигляді внутрішньослівної парадигми - упорядкованої сукупності ЛСВ однієї лексеми $^{106}$.

Зазначимо, що існують різні погляди лінгвістів на семантичну структуру слова. Найбільш прийнятною нам видається класифікація компонентів зовнішньої та внутрішньої семантичної структури, розроблена В. Г. Гаком [Москва, 1998], яка також описана в роботах таких вчених, як Л. А. Лисиченко [Харків, 1977], Ж. П. Соколовська [Київ, 1979], Г. А. Уфімцева [Москва, 1974], Д. М. Шмельов [Москва, 1964] та ін. Розрізняються семантична структура слова та структура окремого значення слова. Перша включає в себе сукупність окремих значень (лексико-семантичних варіантів), серед яких виділяються основне та похідні. Кожне значення слова являє собою сукупність елементарних смислів (сем) ієрархічно організовану структуру, в якій виділяється родовий смисл (архісема), видовий смисл (диференційна сема) та потенційні семи, що відображають різні асоціації, побічні властивості об’єкта, що реально існують або приписуються йому колективом. Якщо виходити із поняття системності, структура багатозначного слова як семантична єдність «...полягає не в наявній спільності значень, а в певному зв'язку цих окремих значень, закріплених за певним знаком» ${ }^{107}$.

При дослідженні інноваційних значень реєстрових слів Словника було використано поняття структурних семантичних складових частин слова (семем, сем), що при використанні відомого в семасіології методу компонентного аналізу дає можливість описати процеси творення нових одиниць семантичної структури лексичного значення, а також прослідкувати динаміку та характер значеннєвих змін. Вивчення смислових модифікацій, що проводиться шляхом компонентного аналізу, являє собою опис елементів єдиного семантичного цілого: зіставлення вихідного й похідного значень, виявлення мінімальних

${ }^{106}$ Кудрявцева Л. А. Моделирование динамики словарного состава языка / [2-е изд.]. К. : ИПЦ «Киевский университет», 2004. С. 41.

${ }^{107}$ Шмелев Д. Н. Очерки по семасиологии русского языка. М. : Просвещение, 1964. C. 113 . 
складових семантики слова та їх значеннєвої спільності, визначення динаміки сем, причин та шляхів трансформації смислових компонентів слова.

Описуючи механізм значеннєвих зрушень, дослідники спираються саме на особливості семантичної структури слова: «Коли якась лексема потрапляє в інший контекст, незвичне оточення, в іï семантичній структурі поступово розвивається певний вторинний додатковий (явний або прихований) відтінок, що згодом може викристалізуватися у окреме значення. Як правило, спочатку це відбувається в мовленні, часом спорадично й невимушено як індивідуальноавторський пошук (вільний чи зумовлений певними прагматичними потребами),... на одиницю нижчого рівня (слово) тисне одиниця вищого порядку (текст). Переносне значення з'являться поступово на основі повторюваних і підхоплюваних мовцями ряду переносних вживань, у яких міститься нетрадиційне бачення реалій, подій, явищ, ситуацій. Тобто первинні індивідуально-авторські та оказіональні лексико-семантичні варіанти значення, які активізуються в узусі, поступово стають загальновідомими, i, відповідно, нормативними і кодифікованими» ${ }^{108}$.

Щодо класифікації семантичних змін, то сучасна лінгвістична наука не подає їх єдиної картини, що задовольняла б усіх мовознавців. У нашій роботі ми йдемо за тією схемою, що диктує фактичний матеріал, який свідчить про те, що причинами появи семантичних неологізмів $\epsilon$ такі основні процеси: метафоризація, термінологізація та детермінологізація.

\subsection{2. Процес метафоризації як одне із основних джерел поповнення словникового складу}

Істотну частину семантичних новацій досліджуваного матеріалу становлять переносні значення у загальновживаних словах, які з'явилися внаслідок процесу метафоризації, що $\epsilon$ важливим джерелом збагачення виражальних засобів мовного словника. У межах аналізованих семантичних

${ }^{108}$ Стишов О. А. Українська лексика кінця ХХ століття (на матеріалі мови засобів масової інформації). К. : Вид. Центр КНЛУ, 2003. С. 212-213. 
процесів, за нашими підрахунками, в новому СУМі нараховано близько 60 \% інноваційних одиниць, утворених шляхом метафоризації.

Метафора - один із способів відображення картини світу, універсальна модель перетворень наявних в мові лексичних одиниць ${ }^{109}$. Метафоризація як явище значеннєвої динаміки словникового складу полягає у семантичному переосмисленні об'єкта дійсності унаслідок порівняння його з іншим об'єктом за подібністю властивостей, ознак, рис, форм i т. ін. Тобто в основі метафоричного найменування лежить «...здатність людини вловлювати схожість і подібність між різними індивідами, класами об’єктів, а потім за цією схожістю переносити назви справжнього носія чи функції на характеризовану особу чи предмет» ${ }^{110}$.

Фізична оболонка (звуковий комплекс) слова, яке вживається в інноваційному значенні, набуває нового вигляду й нової функції, наповнюється новим психологічним смислом, що нерідко супроводжується стилістичною міграцією та емоційно-експресивною конотацією. «У багатьох випадках семантичні переноси обумовлені не необхідністю назвати які-небудь нові предмети та явища навколишнього життя, а намаганням дати нові експресивні назви предметам i явищам, які вже існують» ${ }^{111}$. Активність зазначеного семантичного процесу пояснюється насамперед характерною для епохи сьогодення рисою комунікативної функції мови - подати вербальне відображення дійсності за допомогою образних, яскравих та містких засобів.

Актуальні для досліджуваного матеріалу семантичних інновацій модифіковані метафоричні значення лексичних одиниць різними способами співвідносяться з первинною семантикою слів. Насправді, метафора як спосіб породження нових значень дуже поширена, під дію цього явища підпадає

${ }^{109}$ Кудрявцева Л. А. Моделирование динамики словарного состава языка / [2-е изд.]. К. : ИПЦ «Киевский университет», 2004. С. 44.

${ }^{110}$ Мацько Л. І. Стилістика української мови: підруч. [для студ. філол. спец. вищ. навч. закл.] / Л. І. Мацько, О. М. Сидоренко, О. М. Мацько; [ред. Л. І. Мацько] [2-е вид.]. К. : Вища шк., 2005. С. 239.

111 Лексика современного русского литературного языка / [под ред. М. В. Панова]. М. : Наука, 1968. С. 47. 
багато слів, розширюючи свою семантичну структуру. Метафора $є$ свого роду засобом, «знаряддям» відображення предметів і явищ навколишньої дійсності. Як відомо, «...метафора - це не тільки прийом зображення, це спосіб мислення, спосіб сприймання світу. Метафора соціальна. Метафори показують, як картина світу відображується в суспільній свідомості та яка вона, ця картина світу» ${ }^{112}$.

Аналізований масив лексики підтверджує думку О. А. Земської про те, що соціальна характеристика відображається в появі нових метафоричних номінацій, де метафорично позначуваний об’єкт і його співвіднесеність 3 позначуваним виражає відношення суспільства до предмета думки: «Слова, що 3'являються на наших очах, відображають певне сприйняття дійсності людиною, соціальну та індивідуальну оцінку явищ життя» ${ }^{13}$.

Метафоричне використання конкретної лексичної одиниці пов'язане також зі змінами в складі носія літературної мови, із лінгвістичними смаками, які відбиваються на конкретній реалізації способів номінації, «...розвиток значення в слові отримує відому смислову перспективу і широкі можливості суб'єктивних застосувань на фоні різноманітного мовного варіювання ${ }^{114}$.

Роль індикатора нового значення відіграє насамперед його контекстне вживання. Саме текстове оточення визначає семантичне навантаження слова та його нову комунікативно-функціональну роль, що спричиняє переосмислення лексеми та появу інноваційного ЛСВ. «Сутність смислової зміни слова в площині засобів мовного вираження значення виявляється в розширенні або звуженні кола сполучуваних з ним слів - його семантичного контексту, зміні типів лексико-граматичних зв'язків та відношень між словами як елементами загальної системи словника» ${ }^{115}$.

${ }^{112}$ Русский язык конца ХХ столетия (1985-1995) / [под ред. Е. А. Земской] [2-е изд]. М. : Языки русской культуры, 2000. С. 45.

113 Земская Е. А. Активные процессы современного словопроизводства // Русский язык конца ХХ столетия (1985-1995) / [под ред. Е.А.Земской] [2-е изд.]. М. : Языки русской культуры, 2000. С. 201.

114 Лексика русского литературного языка XIX начала XX века / [отв. ред. Ф. П. Филин]. М.: Наука, 1981. С. 271.

115 Уфимцева А. А. Опыт изучения лексики как системы (на материале английского языка). М. : Изд-во Академии наук СССР, 1962. С. 257. 
У лексико-семантичній системі мови закладені великі потенції семантичної еволюції лексичних одиниць. Внутрішні мовні можливості розвитку значення слова, що проявляються в певних умовах, спричиняють постійні семантичні зсуви: «Історія слова, - підкреслював академік В. М. Русанівський, - включає в себе значно більше значень, ніж ті, що воно їх має в кожний конкретний момент. Поки слово функціонує, воно потенційно може ставати носієм несподіваних значень» ${ }^{116}$.

У мові існує багато видів переосмислення значення слова. В нашій роботі розглянемо явище метафоризації як найбільш потужний чинник переосмислення значення слова. Одним із породжених цим процесом явищ $\epsilon$ метафори, які супроводжуються переоцінкою стилістичного статусу слова, де важливим фактором стає соціальна кваліфікація поняття.

Серед найпоширеніших семантичних інновацій, що з'явилися шляхом метафоризації, $\epsilon$ ті, що відображають зміни значень, обумовлені зсувами стилістичного характеру. У функціонально-стилістичному плані відбувається міграція слів у різних стилістичних пластах та сферах вживання лексики, 3 відповідною оцінною характеристикою. При цьому відбувається її метафоричне переосмислення, а також зміна стилістичного статусу, коли слова (як правило, загальновживані) переходять в розряд розмовної, жаргонної, іронічної та ін. лексики. Активність метафоризації у цих сферах мовлення пояснюється тим, що «...експресивне забарвлення метафори (чим несподіванішою $є$ виявлена у деривата подібність, тим яскравіший створюваний образ) робить ï незамінним засобом номінації у розмовному, просторічному мовленні та в сленгу, а також в термінологіях та професійному розмовному мовленні» ${ }^{117}$. Експресія як спосіб вираження почуттів, відношення до об’єкта мовлення забезпечується емоційнооцінним компонентом, який відіграє значну роль у появі метафоричних значень. Із думкою про об’єкт можуть бути пов’язані позитивні і негативні емоції

${ }^{116}$ Русанівський В. М. Життя слова / В.М. Русанівський, С. Я. Срмоленко. К. : Вища шк. при КДУ, 1978. С. 67.

${ }^{117}$ Кудрявцева Л. А. Моделирование динамики словарного состава языка. [2-е изд.]. К. : ИПЦ «Киевский университет», 2004. С. 79. 
суб'єкта. Цей компонент лежить в основі опозицій багатьох слів ментального поля, їх значень. Емоційність та експресивність дозволяють точніше передати своє ставлення до події, сприяють переконанню, впливу на слухача. «Емоційний компонент, - за словами В.Г. Гака, - нашаровуючись на об'єктивно-комунікативний аспект висловлювання (тобто на його номінативний аспект), підкріплює його» ${ }^{118}$. Тому, на думку дослідника, «Мобілізуючою функцією емоцій і пояснюється, напевно, тенденція до препозиції модальноемоційно-оцінного компонента стосовно до диктального, що розкриває суть події»» ${ }^{119}$.

Матеріали 20-томного Словника української мови продемонстрували, що метафоричного переосмислення зазнав великий масив лексики, серед якої значне місце займають слова на позначення дій та процесів.

Так, наприклад, увійшла в активне слововживання лексема засвічувати із новим значенням та конотативною оцінкою «жартівливе»- 'робити помітним, відомим’ (жарт.). Вона 3'явилася в результаті переосмислення початкового значення слова 'запалювати що-небудь для освітлення, викликати свічення чогось; світити'. Основою метафоричного переносу стала асоціативна ознака, притаманна вихідному значенню слова. Таким асоціативним смисловим компонентом $є$ результат засвічування: навколишнє стає видимим. Тобто вихідна й похідна семеми пов'язані між собою процесуально-результативними зв’язками, що апелюють до світоглядної компетенції мовця засвічувати значить 'робити помітним', що й обумовило виникнення нового значення.

Такий же механізм розвитку вторинного значення, що описаний вище, спостерігається при метафоричному переосмисленні слова уляпатися. Первинне вживання цього слова 'забризкатися, обляпатися чим-небудь' СУМ фіксує як загальновживане, нейтральне. Прихована асоціативна сема 'неприємно почуватися внаслідок цього' сприяє вивільненню емоційноекспресивного заряду лексеми і стає елементом архісеми нового відтінку цього слова 'потрапити у скрутне, неприємне становище' (розм.).

118 Гак В. Г. Языковые преобразования. М. : Языки русской культуры, 1998. С. 79.

119 Там само. 
Подібним чином відбувається процес модифікації семантики і в слова приповзати. Початкове його значення 'повзучи, діставатися куди-небудь' стосується характеру, особливості руху тварини чи людини. Метафоричне переосмислення цього значення 'прийти до когось 3 якимось проханням, принижуючись; принизливо просити пробачення' (розм.) відбулося на основі асоціативного зв'язку - особливості пересування (повзти внизу на животі) екстраполюються на особливості поведінки - принижуватись.

Дієслово обламуватися (також і слово облом) в результаті метафоризації набуває іншого змісту. Первинні значення цієї лексеми - 'ламаючись, відділятися від чого-небудь 3 усіх боків, по краях' та 'утратити можливість продовжувати пересування, роботу через несправність машини, механізму і т. ін.'. Мовні ситуації, в яких розвинулося нове значення, мотивували емоційно-експресивне забарвлення цього словесного знака як жаргонного: 'зазнавати невдач, розчарування у своїх планах, надіях і т. ін.' (жарг.). У цьому випадку переосмислення відбувається на основі імпліцитного елемента архісеми вихідного значення 'переставати діяти', яка мотивує появу похідного значення.

Подібна модель лягла також в основу переосмислення слів відключати 'роз'єднавши, вимикати 3 мережі (електричної, телефонної, газової і т. ін.); відмикати (у 2 знач.)' $\rightarrow$ 'уводити когось у стан непритомності (ударом, спиртним і т. ін.)' (жарг.); злиняти 'док. до линяти 1; вицвісти' (линяти 1 втрачати свіжість, яскравість первісного кольору; блякнути (у 2 знач.) $\rightarrow$ ‘Зникнути, залишити попереднє місце перебування' (розм.).

Модифікації значення зазнала також лексема позависати. 11-томний СУМ фіксує у ній таке значення: ‘зачепившись за що-небудь, тримаючись на чомусь, повиснути (про всіх або багатьох, усе або багато чого-небудь)'. У процесі вживання слова в розмовній практиці у нього розвивається нова семантика 'надовго затриматися в якомусь місці (про всіх або багатьох, усе або багато чого-небудь)' (розм.). ІІї появі послужив прихований елемент архісеми початкового значення слова 'затриматися в якомусь місці'. 
Схожим чином мовлення розвинуло нове значення слово розгаласуватися 'здійняти великий галас (у 1 знач.); сильно розкричатися, розшумітися, розлементуватися’ $\rightarrow$ ‘виявити підвищений інтерес до якогось питання, активно його обговорюючи i привертаючи до нього увагу широкої громадськості'(зневажл.). Архісема первинного значення 'кричати' виступає в якості диференційної семи вторинного значення, створивши умови для переосмислення слова.

Явище метафоризації через стилістичні зсуви значно розширило можливості лексичного сполучення й інших лексем, наприклад, первинні значення слова позавалювати - 'звалити, заповнити чимось усе або багато чого-небудь, скрізь або в багатьох місцях' та 'обвалюючи або розламуючи, зруйнувати все або багато чого-небудь' трансформувалися у вторинне 'провалити, не пройти успішно (переважно іспити) (про всіх або багатьох)' (розм.). Зміна семантики відбулася на основі відповідних асоціативних ознак: руйнування, ламання викликає негативну реакцію, сприймається несхвально, $\mathrm{i}$ метафоричне переосмислення в цьому випадку відбувається саме на їх основі.

Така модель переосмислення обумовила появу інших метафоричних утворень: рулювати 'правити рулем' та 'повертаючи руль або те, що його замінює, вести, примушувати рухатися що-небудь у певному напрямку' $\rightarrow$ ‘їхати, йти, рухатися’ (розм.); випиратися 'з силою пробиваючись, виходити назовні' $\rightarrow$ 'ставати попереду інших’ (фам.); вирубувати 'рубаючи, звалювати 3 кореня все на якій-небудь ділянці (кущі, дерева, ліс і т. ін.)' $\rightarrow$ 'говорити 3 підкресленою старанністю’ (розм.); перекурювати 'курити протягом недовгого часу, під час невеликої перерви в роботі, заняттях і т. ін.' $\rightarrow$ 'відпочивати, робити невелику перерву в роботі' (розм.).

Обстежений матеріал показав, що лексичні одиниці, представлені в СУМ20 новими семемами, значно збільшили значеннєвий обсяг української лексики. Вони 3'являються в мові з метою надання більшої емоційності найменуванням дій, процесів, які мали до цього емоційно нейтральну назву. Таким чином, метафоричні утворення відображають сучасну тенденцію до активізації експресивних форм, «Адже кожна доба розвитку мови пов’язана 3 пошуками й 
конструюванням нових метафор: неповторні відтінки i риси, оригінально поєднуючи їх в метафоричні образи, відкривають нові асоціації» ${ }^{120}$.

Цілий ряд переносних осмислень з'явився також в іменних найменуваннях, зокрема у словах на позначення осіб, у яких відображається ставлення до них суспільства і відповідна емоційна характеристика. Дійсно, мовний матеріал демонструє механізми змін у значеннєвій структурі слова, як здійснюється оцінка, виражається відношення мовця до об'єкта думки, і як, у свою чергу, з'являється відповідне ремаркування нової семантичної одиниці. О. О. Тараненко, описуючи семантичні зміни в структурі слова через процес метафоризації, зазначає: «Метафора - це приховане порівняння, це приховане може бути як дуже позитивне, так і негативне» ${ }^{121}$.

Так, новий СУМ фіксує появу значної кількості негативно-оцінних, пейоративних метафор. Нові переносні значення слів, переважно з ремарками «розмовне» та «жаргонне», рідше «зневажливе», «вульгарне» 3’явилися в результаті їх вживання з відповідною оцінною характеристикою.

Наприклад, лексична одиниця авторитеm вживалася в 11-томному Словнику з семантикою 'загальновизнане значення, вплив, поважність (особи, організації, колективу, теорії і т. ін.)' та 'про особу, що має вплив, повагу, заслуговує на повну довіру’. Останнім часом слово набуло нового трактування 'лідер, ватажок кримінального угруповання' (жарг.). Якщо зіставимо ці два значення, то побачимо, що такому розвитку семантики послужили диференційні семи вихідного значення - 'вплив', ‘повага', ‘довіра', які стали асоціативними семами похідної семеми, адже ватажок обов'язково повинен бути впливовим, а також мати інші відповідні якості. Отже, виділяючи асоціативні ознаки, які лежать в основі метафоризації в цьому випадку, можна говорити про те, що «...це не елементи власне значення слова, а стійкі асоціації, пов’язані з уявленням про явище, що позначає слово,... будучи основою для

120 Лексика русского литературного языка XIX начала XX века / [отв. ред. Ф. П. Филин]. М.: Наука, 1981. С. 219.

121 Тараненко А. А. Языковая семантика в ее динамических аспектах. К. : Наук. думка, 1989. C. 109-110. 
трансформації мовних значень, вони тим самим стають фактами мови, - ці асоціації утворюють великі тематичні поля, втягуючи в сферу свого впливу цілі групи слів і тим самим визначаючи потенційну спрямованість їх “переносного” вживання» 122 .

Словник у 20-ти томах фіксує переносне значення і в слова братва. До значення цієї лексеми 'товариші, друзі' (фам.) після метафоричного переосмислення додалося ще одне, жаргонне - 'члени однієї спільноти (здебільшого - угруповань рекетирів, кримінальних структур і т. ін.)' (жарг.). Зіставлення семантичних структур цих двох семем свідчить про те, що їм властиві спільні смислові компоненти: ‘люди, пов’язані якоюсь спільністю, певними стосунками' - дружбою, довір'ям, відданістю - у вихідному значенні (асоціативні семи) та кримінальною діяльністю - в похідному (диференційні семи).

Експресивно-стилістична трансформація вплинула також на семантику слова бритоголовий. Первинне значення цього слова 'з бритою головою' отримало подальшу семантичну модифікацію через вживання в жаргонному мовленні. Це привело до появи інноваційної семантики 'Член злочинного угруповання, характерною ознакою зовнішності якого є брита голова'. Переосмислення цього слова відбулося за моделлю: перехід архісеми вихідного значення ‘з бритою головою’ у диференційні семи похідного, поява у ньому нової архісеми 'член злочинного угрупування' (жарг.). Така модель отримала реалізацію завдяки дії асоціативної метафоризації, в основі якої лежить екстралінгвістичний досвід носіїв мови.

Такий же тип переосмислення відбувся і в структурі слова борзий. Початкова семантика 'прудкий, швидкий, моторний' вживається на позначення позитивних рис людини. Використання в зневажливих контекстах розвиває вторинне переносне значення лексеми, яка містить негативне забарвлення: 'про пихату, нахабну людину' (зневажл.). Воно з'явилося в результаті актуалізації прихованих асоціативних сем: нахабні люди, як правило, дуже спритні, активні,

122 Шмелев Д. Н. Современный русский язык. Лексика. М. : Просвещение, 1977. С. 193. 
напористі, що синонімізується з характеристиками первинного значення цього слова.

За словами дослідника О. О. Тараненка, «Перенос форм 3 переноснооцінним значенням на негативне поняття - звичайне явище» ${ }^{123}$. Внаслідок такого переносу виникає різка невідповідність між їі старою формою і новим змістом, завдяки чому і здійснюється бажаний ефект. Це ми спостерігаємо в проаналізованому матеріалі, який демонструє модифікації значення, відображаючи переосмислене представлення певних рис, якостей тощо.

Такий тип метафоризації значення відбувається і в інших інноваційних одиницях, які демонструють процес семантичної неологізації. Так, стильове переосмислення вплинуло i на вживання слова крутий. В цьому випадку основою для процесу метафоризації стала властива більшості семем цього багатозначного слова диференційна сема 'дуже', яка служить їх об'єднанню в одну лексико-семантичну структуру: 'дуже загнутий, вигнутий, сильно закручений'; 'з різкою, раптовою зміною напрямку (про поворот шляху, річки і т. ін.'; ‘дуже складний для розуміння'; ‘дуже густий, щільний внаслідок тривалого варіння (про їжу)'; ‘дуже насичений, міцний (про настій, навар, тютюн і т. ін.)'. Ця сема існує і в нових ЛСВ 'Особливий, рішучий, неординарний і т. ін., який має певні специфічні якості' та 'у знач. ім. крутий' 'Особлива, рішуча, неординарна і т. ін. людина' (розм.); у якості прихованої асоціативної. Ïї актуалізація та заміна архісеми 'об’єкт, явище, поняття та ін.' $\rightarrow$ 'людина' складає семантичний процес в слові крутий.

Іронічні контексти сформували виникнення нової семеми в структурі слова умілець, в якому новий СУМ фіксує семантику 'спритна людина, що уміє вдало використовувати обставини’ (розм.). Це значення розвинулося на основі попереднього 'той, хто добре знає свою справу, володіє умінням; вправний майстер’. В одну семантичну структуру їх об’єднують диференційні семи на позначення 'той, хто володіє певним умінням'; різняться вони архісемами: ‘вправний майстер’ - у попередньому значенні та ‘спритна людина' - у новому.

123 Тараненко А. А. Языковая семантика в ее динамических аспектах. К. : Наук. думка, 1989. C. $109-110$. 
Переносне значення в лексемі амеби розвинулося 3 основного 'найпростіші одноклітинні організми, які характеризуються наявністю псевдоподій’. Це так звана зооморфна метафора, коли назви тварин, птахів, риб, комах і т. ін. переносяться на людей; в цьому випадку відбулася зміна архісеми тварина - людина. В результаті виникла нова семантична одиниця 'безвільна, безхарактерна, обмежена людина' (розм.). Появі нового значення сприяла актуалізація диференційної семи 'яка не має сталої форми', що є асоціативною для появи диференційної семи метафоричного значення 'яка не має характеру, твердості, волі' (розм.).

Подібна модель розвитку полісемії простежується у семантичних новаціях побутовець 'те саме, що побутописець' (де побутописещь - 'автор побутових творів літератури, живопису і т. ін.') $\rightarrow$ 'засуджений за побутовий злочин' (розм.).

Метафоризація поширила сфери свого впливу також на іменники найменування осіб, які в процесі мовлення набули позитивної суспільної оцінки. Слід підкреслити, що таких номінацій у Словнику значно менше порівняно з тими, у яких розвинулася пейоративна семантика.

Наприклад, лексема ум зі значенням 'те саме, що розум' (розум 'здатність людини мислити, відображати і пізнавати об'єктивну дійсність; певний склад, характер мислення; загальний інтелектуальний розвиток, рівень пізнання, знань кого-небудь'; отримало вторинну семантику 'вчені, фахівці' (розм.). Її основою стало перенесення загальної характеристики ума (задіяні диференційні семи на позначення мислення, пізнання) на людей, які займаються розумовою діяльністю - вчених, фахівців (семантику формують диференційні семи знання, освіта та ін.). Така модифікація вихідного значення слова носить асоціативний характер, при його творенні актуалізувалися загальні уявлення про вчених як про людей, які характеризуються визначними здібностями, високим інтелектуальним рівнем.

Розширилися можливості лексичного сполучення і в словах на позначення конкретних предметів. Ці лексеми також реалізують свої потенції розвитку закладеної в них двоплановості. Це, зокрема, стосується слів чорнило та 
брехунець. Лексема чорнило з первинним значенням 'водний розчин певного барвника, що використовується для писання; атрамент'; отримала переосмислення завдяки прихованій потенційній семі ‘колір’. Її актуалізація послужила появі нового ЛСВ 'дешеве червоне вино низької якості' (жарг.). Вживання слова брехунець у розмовній практиці в значенні 'радіоприймач' (ірон.) стало можливим при опорі на первинне значення слова 'зменшено до брехун (брехун - людина, яка завжди говорить неправду)'. У цьому випадку відбулося переосмислення 'людина - предмет' з опорою на диференційну сему 'говорити', властиву вихідній та похідній семемам. Актуалізація при цьому семи 'неправда' у відношенні до радіоприймача стала можливою завдяки масовому негативному колективному досвіду користувачів щодо подачі інформації.

Метафоричне переосмислення значень слів відбувається також і в прикметниках, але 3 меншою активністю. Завдяки розширенню лексичної сполучуваності та сфер вживання прикметників на позначення якостей людей та характеристики явищ та предметів проявляється загальна тенденція метафоризації - подання інформації в образній, емоційній, місткій формі.

У сучасній мовній практиці активно використовується слово класний у значенні 'дуже гарний; чудовий’ (розм.). Вихідним для творення цього ЛСВ стало одне із значень слова клас - 'міра якості, ступінь, рівень чого-небудь'. У дериваційному процесі виявилася активізованою асоціативна прихована сема 'високий рівень', що спричинило виникнення нової семеми.

Подібна модель переосмислення реалізована і при утворенні нового значення у слові тіньовий. Основні його значення в 11-томному СУМі ‘стосовно до тіні, який є тінню’ (де тінь - місце, закрите чим-небудь від променів сонця, сяйва місяця або іншого джерела світла, затінений простір'); ‘від якого утворюється густа тінь'; відтінки значень - ‘який знаходиться в тіні, не освітлений сонцем та який добре росте, розвивається в затінених місцях; який не любить сонця (про рослини)'; 'який знаходиться в тіні, не освітлений сонцем’. Базовою для переосмислення тут стала асоціативна сема, властива основним значенням та відтінкам - 'закритий, прихований від чогось'. Новий 
СУМ фіксує розширення лексико-семантичної структури цього слова через появу нового значення 'який існує, діє незаконно; який ухиляється від податків' (розм.).

Інша група слів представляє такий вид метафоризації, коли семантичні неологізми зберігають свою стилістичну належність - новоутворені лексеми мають статус загальновживаної лексики. Їх метафоричне переосмислення пов'язане в основному з потребою передачі емоційно-оціночного ставлення до об’єкта мовлення, а також з прагненням до таких найменувань, які передають влучні місткі характеристики. Найчастотнішими у таких перейменуваннях виявилися іменникові утворення на позначення людей.

Наприклад, лексема $a c$, первинне значення якої 'льотчик-винищувач, який відзначається літальною і бойовою майстерністю’, зазнала смислового переосмислення на основі диференційної семи 'майстерність'. Новий ЛСВ ‘людина, яка досягла високої майстерності у якій-небудь справі' $\epsilon$ характеризуючим, оцінним найменуванням особи.

Подібної семантичної зміни зазнало слово архітектор 3 початковою семантикою 'фахівець в галузі архітектури, будівничий'. В основу метафоризації лягли прихована сема слів архісеми 'архітектор, будівничий’ тобто той, хто є творцем чогось, яка актуалізувалась у новому значенні ‘ініціатор якого-небудь задуму, починання і т. ін.’.

У слові гігант 'велика на зріст людина; велетень' перетворення семантичної структури відбулося при використанні семантики гіперсеми ‘великий'. У новій семемі 'видатна в якій-небудь галузі людина' значення екстраполюється не на розміри, а на якості, пов’язані з розумовою, суспільною діяльністю.

Актуалізація прихованих периферійних сем вихідного значення дозволила здійснити метафоричне переосмислення також слова ведмежатник, у якому семантика 'мисливець, який полює на ведмедів' трансформувалося в 'злодій, який грабує сейфи' (жарг.). Тут відіграли роль пресупозиційні знання, пов'язані зі словом ведмідь: тобто велика тварина з масивним тілом, полювання на яку або зустріч 3 нею пов’язана 3 ризиком, труднощами, проблемами. У 
похідному значенні ці смисли актуалізувалися й трансформувалися на проблеми, пов’язані зі зламуванням такої масивної та складної речі, як сейф.

Поповнився Словник української мови в 20-ти томах також за рахунок зооморфних метафор, тобто перенесення властивості (риси, якості) тварини на людину. Так, лексема плазуни - 'клас хребетних тварин, до якого належать змї̈, ящірки, черепахи, крокодили та інші тварини, що пересуваються переважно плазом, на животі' розширила кордони своєї семантичної структури. Інноваційний варіант з’явився при опорі на диференційну сему 'пересуватися плазом'. Нова семантика 'той, хто по-рабському схиляється перед ким-, чимнебудь, догоджає комусь, принижується, вислужується перед кимсь' 3’явилася на основі асоціативного зв’язку. При цьому зовнішні риси - пересуватися плазом, на животі - пов’язуються з особливостями поведінки людини - принижуватись.

За подібною схемою 'тварина - людина' 3 актуалізацією прихованих асоціативних сем розвивається нова значеннєва лінія в слові пантера - 'те саме, що леопард’ (леопард - 'великий хижий звір родини котячих з плямистою рудувато-жовтою шерстю, що живе в Африці та Азії). Нову семему 'про жінку, яка своїми манерами нагадує пантеру' формують приховані смисли слова пантера 'хижа, зла, лиха тощо’.

Метафоричним найменуванням людей послужили також переноси значень номінацій приладів або їхніх характеристик.

Прикладом неологізмів цієї групи $є$ слово генератор. В основу переосмислення його первинних значень 'Пристрій чи машина, які виробляють електричну енергію’ та 'Апарат для вироблення, утворення чого-небудь або створення електричних, електромагнітних, світлових або звукових сигналів’ лягла сема 'утворення чого-небудь'. Функція машини, що відображена в цій семі, асоціативно пов'язується також із характеристикою особи, а певні мовні ситуації стимулювали появу нового значення 'ініціатор творення чого-небудь (про людину)'.

Такий характер семантичних змін спостерігається також в лексемі магнетизм. Вихідне значення лексичної одиниці 'властивість магніту, а також провідника 3 електричним струмом або електричних зарядів притягати чи 103 
відштовхувати деякі тіла' переосмислюється в метафоричне 'сила впливу певної особи або ідей на кого-небудь; привабливість'. Архісема 'властивість притягати чи відштовхувати', тобто певним чином впливати, стає прихованою семою нового переносного значення.

Іншим типом семантичних перетворень $\epsilon$ використання слів на позначення споруд, предметів, приладів для найменування понять.

Наприклад, нового метафоричного переосмислення зазнало слово балаган. На базі первинної семантики 'тимчасове дерев'яне приміщення для театральних або циркових вистав на площі, вулиці' розвинулося нове значення 'щось несерйозне, блазнівське, невпорядковане'. Семантичний розвиток цієї лексеми відбувся за рахунок використання семантики диференційних сем 'театральні або циркові вистави на площі, вулиці'. При цьому імпліцитні смисли вихідної семеми стали архісемою результативного ЛСВ.

Аналогічної семантичної зміни зазнала лексема палац із вихідним значенням 'будинок величної архітектури, що має громадське або культурне призначення’ та ‘велика будівля з безліччю кімнат - місцеперебування королів, царів, гетьманів, ханів'. Вживання цього слова як метафори в інтерпретації ‘ідеальний образ чого-небудь’ відбулося через асоціації, які передають семи 'величний', ‘культурний', 'королі, царі, гетьмани, хани'.

За подібною моделлю утворений семантичний неологізм бич, початкове значення якого ‘довгий батіг; канчук, нагайка' та ‘кий або палиця, якою б’ють’. Вторинне значення 'кара, покарання' виникло на основі прихованих асоціативних сем до слів ‘батіг', ‘канчук', ‘нагайка' - тобто те, що завдає болю, приносить страждання. Такий розвиток словесних значень знайшов активне використання в сучасному мовленні, про що свідчать приклади слів осуга 'масні або іржаві плями на воді, рідині' $\rightarrow$ 'неприємне відчуття, що залишається після чого-небудь'; коктейль 'алкогольний напій, що є сумішшю коньяку, лікеру, вин та інших спиртних напоїв, іноді з цукром, прянощами і т. ін.' $\rightarrow$ 'суміш, поєднання чого-небудь різнорідного, різноманітного (про різнопланові речі, справи, відчуття і т. ін.); мішанина (у 1 знач.)'; аксесуар 'другорядні, побічні деталі, які доповнюють що-небудь, створюють фон, обстановку для головного 
(в живописі, скульптурі, літературі)' $\rightarrow$ 'частковість, подробиця, що супроводжує що-небудь головне'; квадрильйон 'число, яке зображують одиницею з 15 нулями, а в деяких країнах (Англія, Німеччина) - 324 нулями’ $\rightarrow$ 'величезна кількість, безмежний простір і т. ін.'; видноколо 'обрій, горизонт' та 'простір, який можна охопити зором' $\rightarrow$ 'сукупність, весь обсяг чого-небудь, доступного для спостереження, дослідження, пізнання'; бумеранг 'метальна зброя австралійських племен, що має форму зігнутої палиці, яка сама повертається до того, хто іï кинув' $\rightarrow$ 'Те, що повертається назад (перев. про якінебудь зловмисні діі); відплата, кара'.

Іншого семантичного наповнення набула одиниця індикатор із значенням 'Прилад, пристрій, що фіксує стан об'єкта спостереження або перебіг якого-небудь процесу’; 'Речовина, яка після введення до розчину змінює свій колір або колір розчину й у такий спосіб дає змогу визначити його хімічну природу'. Новий ЛСВ ‘те, що є показником чого-небудь' виник при опорі на приховані смисли диференційних сем 'визначання, вимірювання, записування', адже ці дії спрямовані на отримання певних показників. Семантична структура слова гілка також зазнала динамічних змін через метафоричне переосмислення первинного значення 'боковий відросток, пагін дерева, чагарника, а також трав’янистої рослини'. Появу нового переносного найменування цього словесного знака стимулювала зміна архісеми та актуалізація семи «зовнішня форма». При цьому утворилося нове узагальнене значення 'відгалуження чого-небудь'.

Зазначена модель належить до числа активних, що підтверджується численними прикладами семантичних модифікацій: витік 'місце, де ріка бере початок' $\rightarrow$ ‘початок, першоджерело, начало чого-небудь'; каркас 'металева або дерев’яна основа якої-небудь речі, споруди і т. ін.; кістяк (у 2 знач.) $\rightarrow$ 'те, на чому побудоване або тримається що-небудь'.

Інший тип метафоричних перенесень грунтується на схожості природних явищ та процесів з тими, що відбуваються в суспільстві. Такі перетворення відбуваються переважно при опорі на приховані периферійні семи вихідного значення слова. 
Зіставлення початкового 'Тепла погода взимку або ранньою весною, яка супроводжується розтаванням снігу, льоду' та результативного 'Тепла погода взимку або ранньою весною, яка супроводжується розтаванням снігу, льоду’ ЛСВ слова відлига показує, що модифікація семантики цього слова відбулася на основі прихованої семи 'оновлення'.

Прикладами подібних метафоричних переосмислень стали також такі слова: обвал 'стрімке падіння великої частини грунту, гірської породи, снігу і т. ін. внаслідок зсуву, руйнування і т. ін.' В основу нового семантичного компонента 'раптове погіршення стану чого-небудь (економіки, виробництва і т. ін.); криза (у 2 знач.)' лягли спільні семи - як імпліцитні, так і експліцитні ‘стрімка, різка зміна; дуже; руйнування'. Відповідні значеннєві модифікації відбулися в семантичній структурі таких слів, як перепад 'падіння води на місці порога, а також такий поріг' (де nоріг - 'кам’янисте поперечне підвищення дна, що порушує спокійну течію річки’) $\rightarrow$ 'різкі зміни в житті людини'; просвіток 'те саме, що просвіт 1-3, 5' (де просвіт - 'проміжок, який утворюється між близько розташованими предметами; отвір у чому-небудь, щілина між чимсь, крізь яку щось проникає, проглядається і т. ін., вільний простір чого-небудь’ та 'світла смуга, пляма на темному фоні, утворена світловим променем') $\rightarrow$ 'початкові, ледве помітні ознаки чого-небудь нового, кращого; проблиск'; клімат 'багаторічний режим погоди, характерний для певної місцевості' $\rightarrow$ 'обстановка, стан, що склалися де-небудь'; мікроклімат 'повітряний режим закритого приміщення, штучний або природний' $\rightarrow$ 'навколишні умови, обстановка, взаємостосунки людей у невеликому колективі, сім'ї; вітер 'рух повітря відносно земної поверхні, викликаний нерівномірним розподілом атмосферного тиску і спрямований із зони високого тиску до зони низького' $\rightarrow$ ‘відомості, новини звідки-небудь'; вітерецьь 'зменш.-пестл. до вітер' (де вітер 'рух повітря відносно земної поверхні, викликаний нерівномірним розподілом атмосферного тиску і спрямований із зони високого тиску до зони низького') $\rightarrow$ 'перші ознаки позитивних змін, оновлення в житті, діяльності кого-, чогонебудь’; відлуння 'відбиті звуки, що долинають здалека, з відстані; луна' $\rightarrow$ 
'відгомін, вияв якихось почуттів, думок і т. ін.', 'відображення чого-небудь у чомусь'.

Помічено, що явище метафоризації, хоча і меншою мірою, охоплює також слова на позначення процесів. В основі метафоричної деривації цих слів лежать асоціативні відношення, які стали основою появи інших переносних значень: розруб 'дія за значенням розрубати, розрубувати 1' (де розрубувати означає 'рубаючи, розділяти, розсікати на частини, шматки' та 'рубаючи, псувати річ’) $\rightarrow$ 'припинення дії, прояву чого-небудь'; діалог 'розмова між двома або кількома особами' $\rightarrow$ 'переговори, взаємодія між країнами, партіями, блоками і т. ін.'; реанімація 'штучне відновлення деяких життєво важливих функцій організму, який перебуває в стані клінічної смерті' $\rightarrow$ 'відродження, відновлення чогось'; адаптаціiя ‘пристосування організму або його окремих органів до умов середовища' $\rightarrow$ 'Звикання людини до нового середовища, нових умов (роботи, побуту)', пристосування певного об'єкта, системи і т. ін. до умов застосування' 'Пристосування (спрощення) тексту для малопідготовлених читачів, для тих, хто починає вивчати іноземну мову'; інфляція 'надмірне збільшення кількості паперових грошей і швидке їх знецінення’ $\rightarrow$ ‘втрата колишнього значення, знецінення'.

Загалом слід констатувати, що модель переосмислення значення слів на основі асоціативних ознак $є$ високопродуктивною в семантичних процесах української мови. Свідченням цього є цілий ряд субстантивних найменувань, метафоричні перетворення яких переводять їх із конкретної лексики в абстрактну, тобто розвиток значення відбувається в сторону його розширення, узагальнення. Взаємодія вихідного і похідного значення демонструє одну з типових особливостей розвитку лексичної семантики: «Вияв взаємної мотивованості різних понять починається в середині семантичної структури лексичної одиниці як носія багатьох семем. Існує така закономірність: чим 
слово конкретніше, тим більше воно має можливостей для перетворення на багатозначне» $^{124}$.

Наприклад, слово нечистота функціонувало в мові зі значенням 'бруд, сміття, відсутність чистоти' та ‘уміст вигрібних ям, покидьки, помиї'. Нова семантика 'зневага до морально-релігійних норм, гріховність, аморальність' формується на основі асоціативного зв'язку матеріальної нечистоти із моральною. Подібна модель лежить в основі переосмислення також ряду інших лексичних одиниць: контур 'Лінія, що окреслює форму кого-, чого-небудь; обрис (у 1 знач.).' та 'графічне окреслення предмета' $\rightarrow$ 'загальний вигляд, зміст і т. ін. чого-небудь, що постає в уяві, в планах тощо; обриси (у 2 знач.)'; навала ‘вторгнення ворожих військ у яку-небудь країну, на якусь територію' та ‘полчища ворожих військ’ $\rightarrow$ 'Велика кількість фактів, речей, думок і т. ін., що перев. має негативний вплив на кого-, що-небудь'; nam 'положення в шаховій грі, при якому гравець не може зробити чергового ходу, не підставивши під удар свого короля, і при якому партія вважається нічиєю’ $\rightarrow$ ‘те саме, що безвихідь’; імперія ‘велика монархічна держава, на чолі якої стоїть імператор’ $\rightarrow$ ‘велика монополія, що здійснює контроль над усією галуззю промисловості, якоюнебудь діяльністю'; квієтизм 'релігійно-етичне вчення, що виникло як течія в католицизмі у XVII ст.; проповідує містико-споглядальне ставлення до життя, байдужість до добра і зла, цілковиту покору Божій волі' $\rightarrow$ 'пасивне, споглядальне ставлення до життя та його проблем'; марафон 'змагання з бігу на велику дистанцію (42 км 195 м); марафонський біг' $\rightarrow$ 'суперництво, змагання, що триває протягом заданого часу'; набат 'сигнал тривоги, що подається ударами дзвона на знак якого-небудь нещастя (пожежі, нападу ворогів і т. ін.).' $\rightarrow$ 'Посилене звертання уваги суспільства на яку-небудь небезпеку; тривога (у 3 знач.)'.

Частотними виявилися семантичні неологізми в групі дієслів, що зазнали значеннєвої модифікації шляхом метафоризації значення. Стосовно іменникових новацій дієслівні утворення займають друге місце. Семантична

${ }^{124}$ Русанівський В. М. Структура лексичної і граматичної семантики. К. : Наук. думка, 1988. C. 65. 
переструктуризація відбулася в словах на позначення дії, направленої на щось або на когось. При цьому в більшості результативних лексем виявлено розширення семантичного обсягу, вони виступають у метафоричнорозширеному значенні.

Новий Словник фіксує появу метафоричного значення у слова обезкрилювати - 'позбавляти творчої сили, натхнення; робити безкрилим (у 2 знач.)'. Воно виникає на основі первинного 'відрізати, виривати або псувати крила; робити безкрилим'. Нове значення виникає на основі семантичної близькості сем 'крила' і ‘бадьорість, натхнення’. Їх пов’язує спільна прихована сема 'те, що підносить' (крила - ‘те, що підносить над землею’; бадьорість, натхнення - 'піднесення творчих сил'). Тобто переосмислення вихідного значення відбувається на основі функціональної подібності семем зі зміною архісеми вихідного значення - замість дієслова на позначення фізичної дії ‘відрізати', ‘виривати або псувати' функціонує дієслово на позначення дії, що стосується духовних речей - 'позбавляти'.

СУМ репрезентує появу нового значення у слова лопати - 'зазнавати поразки, невдачі, краху; збанкрутувати (про підприємство, справу, задум і т. ін.), яке виникло на основі первинного - 'те саме, що лопатися' (де лопатися 'тріснувши, ділитися на шматки'). Порівняння цих двох значень показує, що метафоричне переосмислення відбувається на основі прихованої семи основного значення 'руйнуватися', яка стає архісемою вторинного і вживається уже не у відношенні до конкретного предмета, а до певного закладу, установи, що належить до фінансової сфери.

Опора на приховану сему вихідного значення слова обумовила появу метафоричного переносу в слова відмивати - 'миючи, очищати кого-, щонебудь від бруду, жиру і т. ін.', тобто 'піддавати процесу очищення'. Ця прихована сема актуалізується, стає основою реконструкції семантичної структури лексеми. 20-томний СУМ подає цю одиницю з новими переносними значеннями 'знімати провину, виправдовувати', 'легалізувати незаконно отримані прибутки’. 
Цю групу семантичних інновацій, в основі яких лежить модель актуалізація прихованих сем, можна доповнити такими ілюстраціями: навалюватися 'налягаючи, тиснути своєю вагою' та $\rightarrow$ 'обтяжувати когонебудь, завдавати клопоту комусь'; переполіскувати 'полоскати все або багато чого-небудь', ‘полоскати ще раз, повторно або заново, по-іншому' $\rightarrow$ 'те саме, що пліткувати'; позапродувати 'запродати все або багато чого-небудь' $\rightarrow$ ‘зрадити всіх або багатьох з корисливою метою'; поз'їати 'з’їсти все або багато чого-небудь' $\rightarrow$ 'замучити, морально знищити всіх або багатьох'; позаплутувати 'заплутати все або багато чого-небудь, у багатьох місцях' $\rightarrow$ 'дезорієнтувати або викликати розгубленість, замішання, подив у всіх або багатьох'.

Переважна більшість наведених прикладів представляє знижені, іронічні, пейоративні переосмислення значень слів. Як уже зазначалося, такі метафори істотно переважають у досліджуваному матеріалі. Семантичних неологізмів слів на позначення дій, що містять позитивні конотації або мають нейтральну семантику, значно менше. Так, 11-томний СУМ фіксує у слова насталювати таке значення 'наварювати сталлю i нагострювати що-небудь; сталити (у 1 знач.)'. Нова семантика утворилася внаслідок метафоризації первинної й має таке тлумачення: 'зміцнювати, робити міцним, витривалим, стійким (про характер, душу і т. ін.)'. Імпліцитна сема початкового значення 'наварювати сталлю’ - тобто зміцнювати, стає архісемою вторинного. Це значення може стосуватися як предметів, так і людей.

Зазнала переосмислення також лексема відтягуватися. Семантична структура слова розширилася завдяки новій семемі 'активно відпочивати; знімати напруження'. Імовірно, це значення пов’язане із семантикою слова відтягати - 'куючи, видовжувати що-небудь'. Переосмислення відбулося на основі асоціативних ознак: оскільки кування супроводжується гучним звуком, шумом, це послужило мотивації появи нового лексико-семантичного варіанта, досить популярного в молодіжному середовищі. Метафоризація відбулася шляхом перенесення дії, направленої на предмет, на дію, яку виконує людина або яка спрямована на людину. 
Загалом слід підкреслити, що творення слів шляхом метафоричних перенесень у більшості випадків ілюструє зразки, коли значеннєвий вміст слова змінюється в напрямку від конкретного до абстрактного, розвиваючи семантику слів в бік узагальнення певних процесів та явищ. Досліджувані матеріали представляють цілий ряд таких семантичних інновацій: відлипати 'відставати, відклеюватися (про щось прилипле, приклеєне)’ $\rightarrow$ ‘давати кому-небудь спокій, переставати набридати; насичувати 'наповняти, годувати вволю, досита; задовольняти їжею’ $\rightarrow$ ‘постачати що-небудь у великій кількості, забезпечувати чим-небудь'; купатися 'занурюватися у воду для миття, освіження, загартування і т. ін.' $\rightarrow$ 'заглиблюватися, поринати в думки, почуття і т. ін.'; прорізуватися 'з’являтися, проростаючи над поверхнею щелеп, лоба (про зуби, роги)' $\rightarrow$ проявлятися (про талант, здібності і т. ін.)'; об 'якорюватися 'ставати на якір' $\rightarrow$ 'залишитися, зупинитися десь надовго; осісти (у 4 знач.)'; нахилятися 'змінювати своє пряме положення на похиле' $\rightarrow$ 'мати, виявляти прихильність, любов, симпатію до кого-небудь', ‘визнавати що-небудь, надавати перевагу чомусь, схилятися до чогось'; відштовхуватися 'штовхаючись, відсуватися, віддалятися; відпихатися' $\rightarrow$ ‘віддалятися від чогось', ‘спиратися на щось, брати щось за основу'; відзиватися 'відповідати на чий-небудь поклик, звертання; відгукуватися, відкликатися' $\rightarrow$ 'зворушувати, хвилювати або справляти враження; напуватися 'п'ючи що-небудь, угамовувати спрагу' $\rightarrow$ 'втішатися чим-небудь, зазнавати насолоди, втіхи від чогось'; наковтатися 'наїстися чого-небудь, швидко ковтаючи (у 1 знач.)' $\rightarrow$ 'зазнати, перенести багато страждань, неприємностей і т. ін.; натерпітися'.

Дослідження семантичних перетворень на матеріалі тлумачного Словника продемонструвало, що реалізація розвитку нового значення в сучасній українській мові активно відбувається через процес метафоризації. Формування нових метафоричних одиниць безпосередньо пов'язане 3 внутрішнім потенціалом лексичного значення, який продукує розширення семантичного обсягу слова.

Найбільше нових метафоричних утворень спостерігається в іменниках та дієсловах, прикметникових семантичних неологізмів виявлена невелика кількість. 
Основними напрямками метафоричного переосмислення слів є поява нових значень через стилістичні зсуви та поява нових семантичних переносів, які зберігають свою стилістичну належність.

Аналіз досліджуваного матеріалу засвідчує активне входження до реєстру нового тлумачного Словника української мови в 20-ти томах великого масиву інноваційних утворень, що виникли внаслідок різних процесів семантичної модифікації лексики.

Під впливом семантичного явища метафоризації відбувається використання номінативних одиниць, супроводжуване переосмислюванням їх семантики, що безперечно веде до нових зв'язків та відношень в системі лексики. Описуючи лексичні значення, В. В. Виноградов підкреслює, що «Предмет, названий словом, може виявлятися ланкою різних функціональних рядів, різних сторін дійсності, які включені в загальну картину життя. Слово допомагає осмислити i узагальнити ці відношення. Все це знаходить відображення в розвитку значення слова в мові того чи іншого історичного періоду» $^{125}$. Дослідження нових лексико-семантичних варіантів, зафіксованих у лексикографічній системі СУМа, дозволило виявити специфіку процесів семантичних змін та виявити сфери вживання слів, де вони відбуваються.

Як показало дослідження, розширення семантичної структури слів через виникнення нових метафоричних значень обумовлене перш за все стилістичною переорієнтацією лексики, вживанням загальновживаних слів у переносному значенні, прагненням використовувати емоційно-експресивні засоби вираження. Явище метафоризації суттєво торкнулося іменникових та дієслівних номінацій, меншою кількістю представлені семантичні неологізми в групі прикметників. У значній кількості неологізмів семантична модифікація відбулася через семантичні зсуви. Переважно це стосується слів, інноваційне переносне значення яких кваліфікується як розмовне або жаргонне.

Основою структурно-семантичних перетворень лексичних значень виступає при цьому зміна архісеми вихідного значення. Метафоричні

125 Виноградов В. В. Вопросы современного русского словообразования. Русский язык в школе. 1951. № 2. С. 4-5. 
переосмислення в словах відбуваються при опорі на 1) приховані периферійні семи; 2) актуалізацію асоціативної семи; 3) актуалізацію функціональних диференційних сем; 4) актуалізацію семи «зовнішня форма».

Семантичний процес метафоризації обумовив зміни в лексикосемантичній системі мови, що суттєво розширило межі слововживання лексем і поповнило 20-томний Словник української мови великим масивом нових семантичних утворень.

\section{4. Лексика і фразеологія Святого Письма}

Серед принципів укладання СУМ-20 виділено максимально повне представлення лексики та фразеології Святого Письма. Таким чином, при створенні нового Словника української мови одним із найважливіших джерел поповнення його реєстру був текст Біблії, значення та авторитет якої переоцінити неможливо. Особливе місце цієї книги визначене тим, що вона є винятковою, яка підноситься над усіма іншими літературними творіннями людей, маючи особливий статус Божого одкровення як книга Божих слів, звернених до людей («Усе Писання Богом надхнене і корисне до навчання, до докору, до направи, до виховання в праведності» (2 Тим. 3:16) ${ }^{126}$. Біблійні слова та значення заплановано ввести в новий Словник як пласт лексики, який було, 3 одного боку, мінімально представлено в 11-томнику, а з іншого, - у зв'язку з тим, що тлумачення багатьох понять і реалій подавалися з огляду на тодішню панівну ідеологію - атеїзм. До біблійних найменувань у СУМ-20 віднесено також ряд слів і словосполучень, що у Святому Письмі використовувалися в іншому значенні, але саме цей текст став джерелом їхньої появи. Наприклад, найменування Старий Завіт (Заповіт) і Новий 3aвim (3аповіт) вживаються у СУМ-20 у значенні «частина Святого Письма», яке виникло у цих словосполучень поза біблійним текстом, але вжита тут ремарка бібл. вказує на походження цих словосполучень.

${ }^{126}$ Біблія, або книги Святого Письма Старого і Нового Заповіту із мови давньоєврейської і грецької на українську наново перекладена. К.: Укр. біблійне тов., 2002. 1165 с. 
Для залучення біблійної лексики у 20-томник створено автоматизований конкорданс, який базується на цитованому тексті Біблії у перекладі І. Огієнка, та комп’ютерну інструментальну лексикографічну систему «Біблійний СУМ», в якій представлено біблійну лексику та фразеологію згідно з принципами СУМ-20. Це дало змогу здійснити таку роботу: ввести великий масив лексики, відсутньої в 11томнику; змінити велику кількість дефініцій; доповнити семантичну структуру багатьох лексем; значно розширити ілюстративну базу (до того ж ілюстрації 3 Біблії тепер подаються на першому місці); увести до Словника біблійні фразеологізми, яких зовсім не було в СУМ-11.

Слід відзначити, що створення «Біблійного СУМа» було непростим завданням. Біблія - це унікальний світ, де відомі нам слова, повернуті до системи біблійних тем та ідей, мають специфічні значення. I якщо семантику більшості слів мови формує найближче текстове оточення (словосполучення, речення), то біблеїзми є дуже місткими і багатовимірними поняттями, які набувають обертонів смислу на тлі всієї текстової структури Святого Письма, оскільки через них отримують мовну реалізацію провідні біблійні мотиви й теми. I тому для правильного формулювання тлумачень слів Святого Письма, крім знання його тексту, потрібна велика кількість теологічних словників, енциклопедій, досліджень із герменевтики, екзегетики, тематичних біблійних симфоній, коментарів біблійних текстів.

При укладанні біблійної частини СУМа використовувалася також автоматизована система «Сврейський та грецький лексикони Стронга», де до кожного слова Старого і Нового Завіту подано варіанти перекладів. Адже без спеціальних знань такі біблійні поняття, як, наприклад, віра, спасіння, гріх, покаяння, святість, праведність, закон, благодать, апостол, ангел тощо важко витлумачити правильно. Наведені слова - це біблеїзми, тобто лексеми, які своїм походженням сягають тексту Біблії. Адаптовані мовною практикою, вони набули вже інших значень, що сприймаються як загальномовні. Наприклад, ключове поняття Біблії - віра - у СУМ-20 представлене в такий спосіб: 
BÍPA $^{1}, u$, ж. 1. Упевненість у чомусь, у здійсненні чого-небудь. Йшла [Соломія] уперто і завзято, з вірою, що іiі широкі й високі груди зламають усі перешкоди (М. Коцюбинський); ... // у кого. Впевненість у позитивних якостях кого-небудь, у правильності, розумності чиєїсь поведінки. Я завжди був великим оптимістом і дотепер не втратив віри у людей, у перемогу всього світлого над темрявою і злом (М. Кочюбинський); // Упевненість в існуванні чого-небудь. Віра в безсмертя; Віра в потойбічний світ; Віра в прибульців.

2. Те саме, що дові́р'я. Без міри нема віри (Номис)...

3. бібл. Дар Бога людині, завдяки якому встановлюється ї̈ зв'язок з Богом. Одному бо Духом [Святим] дається слово мудрості, а другому - слово знання тим же Духом, а іншому - віра тим же Духом (Біблія. Пер. I. Огієнка); Віра від слухання, а слухання через Слово Христове (Біблія. Пер. І. Огієнка); // Визнання існування Бога. Тут довелося зачепити питання і про Бога і про чорта, про віру в першого i про всякі мудрощі другого (Панас Мирний); // Те або інше релігійне вчення, віровизнання. - Котилися I наші козачі Дурні голови, за правду, За віру Христову (Т. Шевченко)...

Слід підкреслити, що дефініції у тлумачному словнику відображають загальновживані, загальномовні значення слів. Завдяки наявності біблійних значень Словник, а разом $з$ тим і мова отримують інший, вищий комунікативний рівень, на якому Бог спілкується з людьми через Своє Слово - Біблію.

Загалом робота над Біблійним СУМом проводилась у кількох основних напрямках:

1. Зміна дефініції слова, усталеного словосполучення:

\begin{tabular}{|c|c|}
\hline СУМ-11 & СУМ-20 \\
\hline $\begin{array}{l}\text { А́НГЕЛ, а, ч. 1.У релігійному культі - } \\
\text { надприродна істота, посланець, вісник } \\
\text { бога; зображується звичайно у вигляді } \\
\text { юнака з крилами. }\end{array}$ & $\begin{array}{l}\text { А́НГЕЛ, рідше А́НГОЛ, я́НГОЛ, а, ч. } 1 . \\
\text { бібл. Духовна істота, створена Богом, } \\
\text { посланець, вісник Бога. }\end{array}$ \\
\hline $\begin{array}{l}\text { АНТЙХРИСТ, діал. АНЦИ́ХРИСТ, } \\
\text { а, ч. 1.У християнській релігії - } \\
\text { противник Христа, який нібито з'явиться } \\
\text { перед кінцем світу. }\end{array}$ & $\begin{array}{l}\text { АНТЙХРИСТ, розм. АНЦИ́ХРИСТ, а, ч. } 1 . \\
\text { бібл. Противник Ісуса Христа, який } \\
\text { з'явиться перед Його Другим пришестям, а } \\
\text { також усякий, хто відкидає Ісуса Христа. }\end{array}$ \\
\hline $\begin{array}{l}\text { АПО́СТОЛ, а, } . \quad 1 . \\
\text { євангельськими переказами - кожний із } \\
\text { дванадцяти учнів Христа, яких він } \\
\text { послав проповідувати своє вчення. } \\
\text { Чомусь пригадалося євангельське } \\
\text { оповідання, як апостол Петро зрікся } \\
\text { Христа (Тулуб, Людолови, I, 1957, 40)... }\end{array}$ & $\begin{array}{l}\text { АПО́СТОЛ, а, ч., 1. бібл. (перев. з великої } \\
\text { літери). Повноважний посланець, якому } \\
\text { Ісус Христос доручив проповідувати своє } \\
\text { вчення. А коли настав день, покликав Він } \\
\text { [Ісус Христос] учнів Своїх і обрав із них } \\
\text { Дванадиятьох, яких i апостолами Він } \\
\text { назвав (Біблія. Пер. І. Огієнка); Апостоли з } \\
\text { великою силою свідчили про воскресіння } \\
\text { Ісуса Господа, і благодать велика на всіх } \\
\text { них була! (Біблія. Пер. І. Огієнка); } \\
\text { // Найменування Ісуса Христа. Отож, } \\
\text { святі брати, учасники небесного }\end{array}$ \\
\hline
\end{tabular}




\begin{tabular}{|c|c|}
\hline & $\begin{array}{l}\text { покликання, уважайте на Апостола й } \\
\text { Первосвященика нашого ісповідання, Ісуса } \\
\text { (Біблія. } \\
\text { Пер. }\end{array}$ \\
\hline $\begin{array}{l}\text { БЛАГОДА́ТЬ, i, ж. 1. и.-с. У } \\
\text { релігійному уявленні - щедроти, дари, } \\
\text { ласка невідомих, таємничих сил. Сон, } \\
\text { кажуть, божа благодать, - ні, часом } \\
\text { кара божа! (Л. Укр., I, 1951, 459); Не слід } \\
\text { би закладати руки та ждати з неба } \\
\text { благодаті (Фр., III, 1950, 385)... }\end{array}$ & $\begin{array}{l}\text { БЛАГОДА́ТЬ, і, ж. 1. бібл. Щедра милість } \\
\text { Божа, дарована людині незалежно від їі } \\
\text { заслуг. Закон бо через Мойсея був даний, а } \\
\text { благодать та правда з'явилися через Ісуса } \\
\text { Христа (Біблія. Пер. І. Огієнка); Спасенні } \\
\text { ви благодаттю через віру, а че не від вас, } \\
\text { то дар Божий, не від діл, щяоб ніхто не } \\
\text { хвалився (Біблія. Пер. І. Огієнка); Рушієм } \\
\text { самовдосконалення є прагнення віруючого } \\
\text { повернутися до стану благодаті (із } \\
\text { журн.)... }\end{array}$ \\
\hline $\begin{array}{l}\text { БОГ, рідко БІГ, біга, ч. У релігійних } \\
\text { віруваннях - уявна надприродна істота, } \\
\text { що нібито створила світ і керує ним та } \\
\text { вчинками людей. Була б сестра, } і \text { був би } \\
\text { брат, А то.. нема тепер нічого. Ні бога } \\
\text { навіть, ні пів-бога (Шевч., II, 1953, } \\
\text { 364)... }\end{array}$ & $\begin{array}{l}\text { БОГ, рідко БІГ, ч. 1. род. БІ́га, бібл. (з } \\
\text { великої літери). Творець і Володар Всесвіту, } \\
\text { усього сущого, який керує світом. На } \\
\text { початку Бог створив небо та землю (Біблія. } \\
\text { Пер. І. Огієнка); Боже великий, єдиний, Нам } \\
\text { Украӥну храни, Волі і світу промінням Ти ї̈ } \\
\text { осіни (О. Кониський)... }\end{array}$ \\
\hline $\begin{array}{l}\text { ХРИСТО́С, Христа́, ч. (з великої } \\
\text { літери). Назва міфічної особи І Ісуса, } \\
\text { культ якого лежить в основі } \\
\text { християнської релігії. І з згfдував літа } \\
\text { лихії, Погані, давнії літf, Тойді повісили } \\
\text { Христа, Й тепер не втік би син Марії! } \\
\text { (Шевч., II, 1963, 40)... }\end{array}$ & $\begin{array}{l}\text { ХРИСТО́С, Христа́, ч. (з великої літери). } \\
\text { Титул Сина Божого, віра в якого лежить в } \\
\text { основі християнської релігії; Месія. } \\
\text { Сьогодні в Давидовім місті народився для } \\
\text { вас Спаситель, Який є Христос Господь } \\
\text { (Біблія. Пер. І. Огієнка)... }\end{array}$ \\
\hline $\begin{array}{l}\text { (1) Ве́тхий заві́т - найдавніша, } \\
\text { дохристиянська частина біблії. }\end{array}$ & $\begin{array}{l}\text { (1) Ве́тхий (Стари́й) Заві́т (Запові́т), бібл.: } \\
\text { a) перша частина Біблії (Святого Письма), } \\
\text { написана протягом XIII-I ст. до н. е.... } \\
\text { б) угода, яку Бог уклав } 3 \text { давньоєврейським } \\
\text { народом через закон Мойсея. }\end{array}$ \\
\hline $\begin{array}{l}\text { 6) Нови́й заві́т - церковна книга, яка } \\
\text { містить у собі виклад християнської } \\
\text { релігії }\end{array}$ & $\begin{array}{l}\text { (2) Нови́й Заві́т (Запові́т), бібл.: а) друга } \\
\text { частина Біблії (Святого Письма), написана } \\
\text { протягом І ст. н. е. й додана до Старого } \\
\text { Завіту; комплекс текстів, що містять виклад } \\
\text { історії діянь Ісуса Христа, апостолів, } \\
\text { Об'явлення (Одкровення) Господнє. б) угода, } \\
\text { яку Бог уклав з людством через Ісуса } \\
\text { Христа. }\end{array}$ \\
\hline
\end{tabular}

2. Уведення нових слів.

АПО́СТОЛЬСТВО, а, с., бібл. Покликання, служіння апостола; вид посланництва від імені Ісуса Христа. Через Нього [Ісуса Христа] прийняли ми благодать $i$ 
апостольство на послух віри через Ім'я Його між усіма народами (Біблія. Пер. I. Огієнка).

БОГОЗНЕВА́ГА, и, ж., бібл. Паплюження Бога або догматів віри. Відкиньте $i$ ви [віруючі] все оте: гнів, лютість, злобу, богозневагу, безсоромні слова з ваших уст (Біблія. Пер. І. Огієнка).

БОГОЗНЕВАЖА́ТИ, а́ю, а́єш, недок., бібл. Ганьбити Бога, паплюжити святе, відрікатися від Бога. Як юдеї ж побачили натовп, то наповнились заздрощів $i$ стали перечити мові Павла та богозневажати (Біблія. Пер. І. Огієнка).

БОГОЗНЕВА́ЖНИЙ, а, е, бібл. Прикм. до богознева́га. I побачив я [апостол Іван] жінку, щзо сиділа на червоній звірині, переповненій іменами богозневажними, яка мала сім голів і десять рогів (Біблія. Пер. І. Огієнка).

БОГОЗНЕВА́ЖНИК, а, ч., бібл. Той, хто ганьбить Бога, відрікається від Нього. Будуть-бо люди тодi [останніми днями] самолюбні, грошолюбні, зарозумілі, гордi, богозневажники (Біблія. Пер. І. Огієнка).

БОГОПІЗНА́ННЯ, я, с., бібл. Пізнання Бога. Я милості хочу, а не жертви, $i$ богопізнання більше від ціілопалень (Біблія. Пер. І. Огієнка); Богопізнання доступне всім охочим, але тільки тим, які вірять у Бога, духовно чистим людям ((з рел.-церк. літ.).

\section{3. Розширення семантичної структури слова:}

БЕЗ3АКО́ННИЙ, а, е. 1. Який суперечить установленим законам; протизаконний. Діяльність організованих злочинних утворень спрямована на беззаконне збагачення, створення стереотипу красивого життя, формування особливого типу “крутої” людини, здатної піти на будь-який вчинок (із журн.); // Який іде всупереч вимогам моралі, справедливості. Свій суд беззаконний над вами Катюгисудді вирікали, і ви На смерть волочили кайдани (з народної пісні).

2. бібл. Який суперечить Закону Божому. Бо досить минулого часу, коли ви чинили волю поган, ходили в розпусті, y пожадливостях, у пияцтві, у гулянках, у пиятиках, у беззаконних ідолослужбах (Біблія. Пер. І. Огієнка); // у знач. ім. беззакі́нний, ного, ч. Той, хто порушує Закон Божий. Закон не покладений для праведного, але для беззаконних та для неслухняних, нечестивих $i$ грішників, безбожних та нечистих, для зневажників батька та зневажників матері, для душогубиів (Біблія. Пер. І. Огієнка).

БЕЗЗАКО́ННИК, а, ч., заст. 1. Той, хто порушує закон. Цар .. зараз же бомагу [бумагу] й посилає, Щоб беззаконника такого-то схопить (Л. Глібов).

2. бібл. Той, хто порушує Закон Божий; грішник, нечестивець. Бо ось вороги Твої, Господи, бо ось вороги Твої згинуть, розпорошаться всі беззаконники! (Біблія. Пер. І. Огієнка); I тоді-то з'явиться той беззаконник, що його Господь Ісус заб'є Духом уст Своїх і знищить з'явленням приходу Свого (Біблія. Пер. І. Огієнка).

БЕЗЗАКО́ННЯ, я, с. 1. Порушення правового порядку, законів, установлених у певному суспільстві, державі, в певну епоху. Він [Т. Шевченко] гостро говорив на слідстві про пригнічення панами народу, про беззаконня, які чинили скрізь цуарські чиновники (П. Колесник)...

2. бібл. Сукупність дій, пов'язаних із порушенням заповідей та повелінь Божих; гріх, неправедність, нечестя. Ми прогрішилися та чинили беззаконня, $i$ були 
несправедливі, $і$ бунтувалися, $і$ відверталися від Твоӥх заповідей та від постанов Твоїх (Біблія. Пер. І. Огієнка); Кожен, хто чинить гріх, чинить і беззаконня. Бо гріх - то беззаконня (Біблія. Пер. І. Огієнка); * Образно. Я бачив таких, щцо орали були беззаконня та сіяли кривду, то й жали ї̈: вони гинуть від подиху Божого і від духу гнівного Його погибають! (Біблія. Пер. І. Огієнка).

БРАТ, а, ч. ... 5. бібл. Член духовної християнської спільноти; християнин. $A$ ви вчителями не звіться, бо один вам Учитель [Ісус Христос], а ви всі брати (Біблія. Пер. І. Огієнка); [К е м б ль:] Ми всі брати і сестри по Христу, і всім повинна просто “ти” казати, хоч би й самому королеві (Леся Українка)...

ВІДКУПО́ВУВАТИ, ую, уєш, розм. ВІДКУПЛЯ́ТИ, я́ю, я́єш $i$ ВІДКУПА́ТИ, а́ю, а́єш, недок., ВІДКУПИ́ТИ, уплю́, у́пиш; мн. відку́плять; док., кого, щзо. ... 3. бібл. Прощати, звільняти людину від гріхів і дарувати вічне життя (про Ісуса Христа). Обізвися до мене, о Господи, .. наблизись [наблизься] до моєї душі, порятуй же ї̈, ради моїх ворогів відкупи Ти мене!.. (Біблія. Пер. І. Огієнка).

ЗАВі́T, у, ч. ... 2. бібл. (з великої літери). Союз, угода між Богом і людьми. $B u$ стоїте сьогодні всі перед лищем Господа, Бога вашого.., щоб ти ввійшов у Завіт Господа, Бога свого, .. щуоб поставити сьогодні тебе народом для Себе, а Він буде тобі Богом (Біблія. Пер. І. Огієнка)...

СЕСТРÁ, и́, ж. ... 5. бібл. Член духовної християнської спільноти; християнка. Коли ж брат чи сестра будуть нагі і позбавлені денного покорму, а хто-небудь із вас до них скаже: Ідіть з миром, грійтесь та їжте, та не дасть їм потрібного тілу, щзо ж то поможе? Так само й віра, коли діл не має, мертва в собі! (Біблія. Пер. І. Огієнка); Поручаю ж вам сестру нашу Фіву, служебницю Церкви в Кенхреях, щуоб ви прийняли ії в Господі, як личить святим (Біблія. Пер. І. Огієнка).

Слід зазначити, що під час роботи 3 біблійною лексикою важливим процесом стало розширення тлумачного словника новими словами і значеннями, які не пов'язані з духовними поняттями, а стосуються найменувань різних реалій життя, побуту, стосунків людей, ознак, дій тощо. Це виявилося не менш потужним джерелом розвинення словникової структури, ніж поповнення біблеїзмами. Наприклад:

БА́ТьКО, а, ч. ... 3. Благодійник, покровитель. Бідарям я був батьком, суперечку ж, якої не знав, я досліджував (Біблія. Пер. І. Огієнка)...

БЕРЕГТИ́, еже́, еже́ш; мин. ч. бері́г, берегла́, ли́; недок., кого, щุо. ... 4. щุо. Дотримувати, пильнувати, виконувати. Хто Закон береже, розумний той син, а хто водиться із гультяями, засоромлює батька свого (Біблія. Пер. І. Огієнка); По правді, по правді кажу вам: Хто слово Моє [Ісуса Христа] берегтиме, не побачить той смерті повік! (Біблія. Пер. І. Огієнка) ...

БИ́ТИ, б'ю, б'єш; наказ. сп. бий; недок. ... 2. ... // чим і без дод., перен. Карати кого-небудь. Я бив вас посухою та зеленячкою [борошнистою росою], сарана жерла безліч ваших садків й виноградників ваших, та ви не вернулись до Мене, говорить Господь (Біблія. Пер. І. Огієнка)... 
БИЧ, á, ч. ... 3. перен. Кара, покарання. Нехай забере Він [Бог] від мене Свойого бича, Його ж страх хай мене не жахає (Біблія. Пер. І. Огієнка)...

БІГУ́ப̈ $\mathbf{1}^{1}$, á, ч. ... 3. заст. Слуга, який біжить попереду екіпажа, а також гонець, посильний. А Адонія, син Хаптітин, бундючився та говорив: Я буду иарювати! I справив він собі повоза та верхівиів, та п'ятдесят чоловіка [осіб] бігунів перед собою (Біблія. Пер. І. Огієнка)...

БАЛЬЗА́мОВИЙ, а, е. Прикм. до бальза́м. I станеться, як ти [цар Давид] почуєш шелест ніби кроків на верховіттях бальзамових дерев, тоді вийдеш на бій, бо то вийшов Бог перед тебе, щьоб побити філістимський табір (Біблія. Пер. I. Огієнка)...

БЛАГОВОЛі́нНЯ, я, $c$. 1. заст. Дія за знач. благоволи́ти ${ }^{1}$. Хай буде над нами благовоління Господа, Бога нашого, і діло рук наших утверди нам (Біблія. Пер. I. Огієнка)...

\section{4. Фіксація біблійних усталених висловів:}

(1) Віне́ць життя́, рел. - вічне життя, воскресіння праведників після смерті. Апостол Яків говорить: “Блаженний чоловік, щзо .. дістане вінецьь життя, щุо Господь обіияв тим, які його люблять” (Біблія. Пер. І. Огієнка)...

(1) Ві́чне життя́, бібл. - життя, яке буде після воскресіння мертвих і загального суду Божого. Так бо Бог полюбив світ, що дав Сина Свого Однородженого, щоб кожен, хто вірує в Нього, не згинув, але мав життя вічне (Біблія. Пер. I. Огієнка)...

Геєна вогня́нна (огня́нна) - пекло. Коли твоє око тебе спокушає, його вибери й кинь від себе: краще тобі однооким ввійти в життя, ніж з обома очима бути вкиненому до геєни огненної (Біблія. Пер. І. Огієнка)...

Де́рево життя́, бібл. - за Біблією, дерево в Едемському саду, плоди якого $€$ джерелом вічного життя. I сказав Господь Бог: Ось став чоловік, немов один із Нас, щуоб знати добро й зло. А тепер коли б не простяг він своєї руки і не взяв з дерева життя, і щзоб він не з'їв, $і$ не жив повік-віку (Біблія. Пер. І. Огієнка); Хто має вухо, хай чує, що Дух [Святий] промовляє Церквам: переможиеві дам їсти від дерева життя, яке в раю Божім (Біблія. Пер. І. Огієнка);

Де́рево пізна́ння (знання́) добра́ i (й) зла, бібл. - за Біблією, дерево в Едемському саду, плодів якого Бог заповідав не їсти першим людям Адамові та Єві. I зростив Господь Бог із землі кожне дерево, принадне на вигляд $і$ на їжу смачне, і дерево життя посеред раю, і дерево пізнання добра $і$ зла (Біблія. Пер. I. Огієнка); I наказав Господь Бог Адамові кажучи: Із кожного дерева в раю ти можеш їсти. Але з дерева знання добра й зла не їж від нього, бо в день їди твоєї від нього ти напевно помреш! (Біблія. Пер. І. Огієнка)...

5. Уведення ілюстративного матеріалу 3 Біблї̈, в тому числі до загальновживаної лексики. Ці ілюстрації не обов’язково містять якусь релігійну настанову чи мають повчальний характер (хоча багато й таких), вони просто відбивають певні сторони дійсності. Наприклад: 
АРАМІ́ЙСБКИЙ, а, е. Стос. до арамеїв, належний, власт. їм. Ісак поблагословив Якова і послав його до Падану арамейського, щоб узяв собі звідти жінку (Біблія. Пер. І.Огієнка)...

БАГРЯ́ЯИЙ, а, е. Густо-червоний, пурпуровий. I вийшов назовні Ісус у терновім вінку та в багрянім плаші. А Пілат до них каже: Оче Чоловік! (Біблія. Пер. I. Огієнка); Розжеврене, червоне сонще низько Спустилося, багряним світлом грало По деревах, по квітках і по річиі (Леся Українка)...

БАЖА́ТИ, а́ю, а́єш, недок. 1. чого або з інфін. Прагнути, мати бажання здійснити, одержати, здобути що-небудь; хотіти. I як бажаєте, щоб вам люди чинили, так само чиніть їм і ви (Біблія. Пер. І. Огієнка); Серие моє трудне. Чого ти бажаєш, щңо в тебе болить? (Т. Шевченко)...

ВИБА́чЛИВИЙ, а, е. 1. Який виявляє поблажливість; несуворий. $\underline{T u, ~ Г о с п о д и, ~}$ добрий і вибачливий, $і$ многомилостивий для всіх, хто кличе до Тебе! (Біблія. Пер. I. Огієнка); 3 таким посміхом, вибачливим, стриманим, старші дивляться на пустощі улюбленої дитини (О. Донченко)...

ДАР, у, ч., уроч. 1. Те, що підноситься, жертвується; подарунок... Дар Божий вічне життя в Христі Iсусі, Господі нашім! (Біблія. Пер. І. Огієнка)...

НЕМУ́ДРО. Присл. до нему́дрий. $Я$ дуже згрішив, що зробив ие! A тепер, Господи, відсунь же провину Свого раба, бо я дуже немудро вчинив!... (Біблія. Пер. І. Огієнка)...

Мова тексту Біблії, яка апелює до серця людини, є дуже образною, в ній багато епітетів, метафор, алегорій, символів, слів та виразів із переносним значенням. Вона збагатила зміст СУМа багатьма порівняннями, метафоричними та фразеологічними виразами:

3Е́РНО́, зе́рна́, c. ... 2. Насінина плодів певної рослини. Вона навіть не вибирала й не їла зерен $i$ викидала з рота зерна з лушпайками (І. Нечуй-Левицький); Особливу симпатію викликав шкутильгаючий коник Черниша... Йому давали вилущені горіхові зерна, персики, виноград, і він усе охоче поїдав (О. Гончар); // y знач. збірн. Зерно бобових культур має досить різноманітне використання (з наук. літ.); * У порівн. По правді кажу вам: коли будете ви мати віру, хоч як зерно гірчичне, $і$ горі очій скажете: Перейди звідси туди, то й перейде вона, і нічого не матимете неможливого! (Біблія. Пер. І. Огієнка).

ВИТЯГА́ТИ, а́ю, а́єш, ВИТи́ГУВАТИ, ую, уєш, недок., ВИ́ТЯГТИ, ВИ́ТЯГНУТИ, гну, гнеш; мин. ч. ви́тяг, ла, ло $i$ ви́тягнув, нула, ло; док., кого, щ̧o... $\diamond$ Ви́тягти (ви́тягнути) / витяга́ти (витя́гувати) 3 боло́та (3 багна́, 3 калю́жі, з грязю́ки $i \mathrm{~m}$. ін.) кого: а) допомогти кому-небудь вийти з принизливого становища або позбутися злиднів. Витяг мене Він [Бог] із згубної ями, із багна болотистого, $і$ поставив на скелі ноги мої, $і$ зміџнив мої стопи (Біблія. Пер. І. Огієнка)...

ГЛИ́нА, и, ж. Багатомінеральна гірська порода, перев. осадового походження, яка 3 водою утворює пластичну масу; широко використовується у будівництві, гончарстві, скульптурі і т. ін. Назносим каміння, назносимо глини, Збудуємо хатку 
з дверима у сіни (М. Коцюбинський); $\Theta$ добра глина, цеглу з неї роблять... (А. Шиян); * Образно. Тепер же, о Господи, Ти наш Отеиь, ми глина, а Ти наш гончар, і ми всі чин Твоєї руки! (Біблія. Пер. І. Огієнка); * У порівн. Усе міняється, виліплюється, мнеться, мов глина творчая у скульптора в руках (П. Тичина)...

СКЕ́ЛЯ, i, ж. Кам'яна брила або гора 3 стрімкими схилами та гострими виступами. Над самою водою стояла висока, але не широка скеля, ніби стіна 3 каміння (І. Нечуй-Левицький); На флангах не було не лише доріг, а навіть стежок .. Там починались дрімучі ліси і прямовисні стіни диких скель (О. Гончар); Пристані там не було, ні затоки, де б суднам ховатись; Всюди лиш кручі, та скелі суворі, та рифи стирчали (Борис Тен, пер. $з$ тв. Гомера); * Образно. Господь моя скеля й твердиня моя, $і$ Він мій Спаситель! Мій Бог моя скеля, сховаюсь я в ній (Біблія. Пер. І. Огієнка).

Таке повне i багатостороннє включення мовного матеріалу Біблії до Словника української мови дає підстави стверджувати, що цей Словник посяде особливе місце у фундаментальній національній лексикографії, оскільки тут подано об’єктивне (незаідеологізоване), докладне, різноаспектне представлення Слова Божого через систему лексикографування. Завдяки цьому здійснено реальний поступ для належної та достойної репрезентації Святого Письма у сучасній українській літературній мові. 


\section{РОзділ 18}

\section{ОСОБЛИВОСТІ ПРЕДСТАВЛЕННЯ ТЕРМІНОЛОГІЧНОЇ ЛЕКСИКИ В СЛОВНИКУ УКРАЇНСЬКОЇ МОВИ У 20-ТИ ТОМАХ}

\section{1. Термінологія як об'єкт лексикографії}

\subsection{1. Розвиток науки й сучасне термінознавство}

Термінологія - нині невід'ємний і важливий складник лексичної системи. Також вона є невіддільною частиною наукової мови, що засвідчує досягнення кожної окремої ділянки знання на певному етапі їі розвитку. Про рівень прогресу в певній галузі, а також про можливості конкретної мови щодо вираження нових наукових понять свідчить багатство та досконалість термінології, що обслуговує цю галузь ${ }^{127}$.

Термінознавчі дослідження різних років переконливо доводять, що фахова лексика відіграє важливу роль у розвитку науки й техніки та здатна певною мірою визначати напрям для подальшого розроблення їхніх теоретичних положень. Як основний засіб вираження, зберігання й передавання спеціальних науковотехнічних понять термінологія забезпечує формулювання проблем і наступність наукових знань. Будь-яка галузь науки й техніки розвивається, спираючись на визначену й зафіксовану в термінах систему понять.

Термінознавство - один із актуальних напрямків сучасних лінгвістичних досліджень, зумовлених великим потоком інформації, процесами інтеграції наук, посиленням процесів термінотворення тощо.

Сучасний етап життя суспільства характеризується суттєвими змінами, зумовленими науково-технічними й соціальними перетвореннями. Прискорені темпи науково-технічного прогресу, інтенсивні дослідження й розроблення на їхній основі новітніх технологій супроводжуються входженням науки й техніки в усі царини людської діяльності. Швидка науково-технічна революція, зміна економічної, політичної тощо ситуації в країні, соціальні зрушення, створення

127 Лепеха Т. В. Лексико-семантичні та словотвірно-структурні особливості судовомедичної термінології: дис... канд. філол. наук: 10.02.01., 2000. С. 5. 
нової державності сприяють виникненню великої кількості явищ, понять, об’єктів, породжують інші форми суспільних відносин між людьми.

Період із середини XX століття до сьогодення можна назвати часом прискореного розвитку наукових знань. Радикальних змін зазнало й суспільне життя людей. Усе це не могло не відбитися на мовній системі, яка стає інформативно насиченішою на всіх рівнях і в усіх функціональних стилях. За спостереженнями дослідників, зростання кількості термінів різних наук випереджає зростання кількості загальновживаної лексики, i тому в наш час термінологічних одиниць нараховується більше, ніж слів загального вжитку ${ }^{128}$. Величезний потік інформації та нових знань у сучасних умовах розвитку суспільства $є$ потужним чинником появи мовних одиниць, зокрема й термінологічних. Вони становлять один із найактивніших пластів лексики сучасної мови, що «...стрімко розвивається, активно взаємодіє з іншими словами словникового складу мови, насамперед із загальновживаною лексикою. Тому вивчення закономірностей утворення термінологічної лексики, іiї структури й семантики стало одним із найважливіших завдань сучасної лінгвістики» ${ }^{129}$.

Оскільки науково-технічний прогрес упливає на всі сфери людської діяльності, суспільний розвиток й на мовну картину світу також, виникла нагальна потреба вдосконалення системи передавання та оброблення інформації, зокрема вербальними засобами.

Починаючи з кінця 60 -х років XX ст. в Україні започатковано різноаспектне дослідження терміносистем різних галузей знання. Нині вже описано близько 150 терміносистем, що охоплюють термінологію різних галузей техніки (машинобудівну, електротехнічну, металургійну тощо), природничих наук (фізики, генетики), економіки, менеджменту, медицини та ін. ${ }^{130}$

${ }^{128}$ Гринев С. В. Введение в терминоведение. М.: Московский лицей, 1993.

${ }^{129}$ Кияк Т. Р. Лингвистические аспекты терминоведения: учеб. пособие. К.: УМК ВО, 1989. C. 3.

130 Докладніше про розвиток українського термінознавства див.: Широков В. Симоненко Л. Досягнення й розвиток українського термінознавства від 90-х років XX ст. початку XXI ст. Актуальні проблеми романо-германської філології та прикладної лінгвістики. Чернівці, 2014. № 2. С. 239-248. 
3 90-х років XX ст. - початку XXI ст. активно й плідно розвивається українська термінологічна лексикографія, удосконалюються методологічні засади термінографічної роботи. За останне двадцятиліття надруковано близько 800 термінографічних праць у різних регіонах України. Етапним для українських термінологічних досліджень став вихід «Російсько-українського словника наукової термінології» у трьох книгах («Суспільні науки», 1994 р., «Біологія. Хімія. Медицина», 1996 р., «Математика. Фізика. Техніка. Науки про Землю та Космос», 1998 р.), «Словника української біологічної термінології» (2012р.).

\subsection{2. Галузева лексика у великих загальномовних тлумачних словниках}

Дослідження термінологічної лексики, з'ясування іï характерних ознак, тенденцій розвитку, творення тощо $\epsilon$ важливим i непростим мовознавчим питанням. Безперервне збільшення обсягу й ускладнення змісту наукової інформації в сучасному суспільстві актуалізує комплексне й системне вивчення наукової термінології, визначаючи нові завдання й підходи. Фіксація нових термінів, способи відтворення в мові, їх кодифікація - ключові проблеми сучасного термінознавства. Загальновизнана важливість завдань термінознавства сприяє значному масштабові досліджень у цій сфері. Тому цілком природно, що мовознавці надають великого значення вивченню закономірностей утворення термінів, їхньої структури й семантики, аспектам упорядкування, перекладу тощо.

Відомо, що найуживаніша термінологія різних галузей знань міститься в загальномовних словниках, зокрема тлумачних, перекладних. Проблема введення термінів до загальномовного словника випливає 3 його завдань: описати лексичний арсенал, який розкриває загальну панораму сучасної науки і прогресу суспільства ${ }^{131}$.

Проблема співвідношення термінології й загальновживаної лексики постійно привертає увагу дослідників, однак дотепер немає єдиного погляду на

${ }^{131}$ Симоненко Л. О. Термін у загальномовних словниках. Українська і слов’янська тлумачна та перекладна лексикографія. Леонідові Сидоровичу Паламарчукові. К.: КММ, 2013. C. 220-221. 
цю проблему. Між загальновживаними й спеціальними словами відбувається постійне взаємопроникнення на рівні обміну мовними знаками (термін - слово загального вжитку й навпаки), використання спільних словотвірних моделей тощо. Саме тому межа між згаданими категоріями лексики є досить умовною. Однак не всі дослідники поділяють цю думку. Дехто з них констатує певний розрив між терміном і загальновживаним словом, інші відзначають їхню єдність. Зокрема, О. Веремчук уважає, що внаслідок «використання терміна у незвичних для нього мовних ситуаціях відбувається нівелювання термінологічної семантики, що призводить до поступового переходу слова зі спеціальним значенням до загальновживаного лексичного фонду» ${ }^{132}$. В. Перерва дотримується думки, що термін, де б він не вживався, завжди залишається терміном - мовним знаком, який інформує про певний об’єкт дійсності доти, поки є цей об’єкт, він завжди готовий виконувати свою основну функцію - збереження й передавання інформаці1̈ ${ }^{133}$.

Оскільки немає єдності в розв'язанні названої вище проблеми, то немає й одностайної думки щодо місця спеціальної лексики в загальномовних словниках. Залежно від обсягу й призначення словника окреслюють основні шари лексики майбутньої лексикографічної праці. Цьому значною мірою сприяє надійна джерельна база, на основі якої створюється реєстр словника. Відомо, що словниковий склад мови активно поповнюється саме за рахунок термінологічної лексики. Термін відіграє велику роль у процесі вербалізації наукових і технічних здобутків людства. Основними його ознаками є: системність, наявність дефініції; тенденція до однозначності в межах свого термінополя, напр.:

ЕПІГЕНЕ́3, у, ч. 1. біол. Вчення про зародковий розвиток організмів як процес, що здійснюється шляхом послідовних новоутворень із безструктурної субстанції заплідненого яйця. 2. геол. Природні вторинні зміни осадових гірських порід після їх утворення.

Для терміна характерна висока інформативність, відносна однозначність, точність і експресивна нейтральність. Значення знака-терміна, з одного боку,

132 Веремчук О. Стилістична транспозиція термінологічної лексики в сучасній українській мові (кодифікаційний аспект). Рівне, 2010. С. 51.

133 Перерва В. М. Перерождаются ли термины в общем употреблении. Современная русская лексикография. Ленинград: Наука, 1980-1981. С. 91-92. 
відзначається об’єктивним змістом відповідного поняття, а 3 другого - свідомим уточненням дослідника меж змісту спеціального поняття. Спеціальні терміни фіксують словники різних типів - від орфографічних до тлумачних, перекладних, етимологічних тощо.

Репрезентативними об’єктами дослідження стають великі тлумачні словники, що відбивають різні періоди розвитку мови й дозволяють проаналізувати галузеву лексику, подану в них, як цілісну динамічну систему. Динамічні процеси в сучасній українській літературній мові впродовж останніх десятиліть спричинили появу великої кількості не лише загальновживаних, а й термінологічних слів, що потребують упорядкування й системного опису в тлумачній лексикографії.

Об’єктивне відображення лексичного складу літературної мови на певному етапі ii історичного розвитку $є$ одним із відповідальних завдань укладачів тлумачного словника будь-якої мови. Саме тому, очевидно, оцінка наукових переваг кожного загальномовного словника майже завжди починається з розгляду питання про повноту фіксації в ньому лексичного інвентарю мови в хронологічних межах періоду, який охоплює цей словник, із виявлення можливого пропуску загальновживаних і особливо актуальних слів, характерних для певного періоду розвитку мови й засвідчених у різних лексичних джерелах ${ }^{134}$.

Термінологія, що надходить у кодифіковану літературну мову з науковотехнічної та професійно-виробничої сфер, є суттєвою частиною реєстру кожного великого тлумачного словника. Добирання термінології до загальномовного словника, іiі системне подання й опис є складним і відповідальним завданням. Через небачений раніше прогрес різних галузей науки й техніки та бурхливий розвиток виробництва для цієї категорії лексики особливо характерні велика динамічність, відносно швидке й вільне переміщення 3 однієї сфери функціонування в іншу, від одного полюса вживаності до іншого. Усе це вказує на велику складність лексикографічного опрацювання термінологічної лексики й на

${ }^{134}$ Паламарчук Л. С. Терминологическая лексика в общеязыковом (филологическом) словаре. Проблематика определений терминов в словарях разных типов. Л.: Наука, 1976. C. 250 . 
особливу відповідальність лексикографа в справі добору слів цієї категорії для конкретного словника ${ }^{135}$.

Лексикографічні праці, у яких опрацьовано значний лексичний матеріал, описано семантичну структуру десятків (а то й сотень) тисяч слів і простежено характер їхнього контекстного функціонування, зробили очевидним те, що в літературній мові нашого часу, у типових літературних жанрах і контекстах (тобто поза спеціальною сферою) зареєстровано величезний масив термінів різних галузей знання й діяльності. Вони засвідчують, що значна кількість неологізмів нашого часу - це нові терміни й що суттєва частина семантичних змін у сучасній мові пов’язана 3 процесом проникнення терміноодиниць у загальномовний вжиток, із їхньою детермінологізацією й розвитком нових значень.

Добираючи термінологічну лексику до тлумачного словника української мови, доводиться розв'язувати багато проблем. Важливим питанням є, зокрема, доцільність введення певної терміноодиниці до реєстру.

На думку С. Ожегова, залучення термінологічної лексики до словника літературної мови потрібно пов’язувати насамперед 3 виходом цих одиниць за рамки спеціального чи фахового використання i входженням їх у лексичну систему загальнолітературної мови ${ }^{136}$.

Певні настанови щодо фіксації фахової лексики подано в дослідженнях Л. Паламарчука. Мовознавець зазначає, що до реєстру загальномовних словників залучається спеціальна лексика різних наук, техніки й виробництва на рівні термінології, що міститься в підручниках загальноосвітньої середньої школи. Однак під час створення конкретних словників цей принцип добору термінологічної лексики, як правило, доповнюється новими настановами, унаслідок чого втрачає свою первісну точність, а також виразну окресленість меж і обсягу цієї лексики в словнику ${ }^{137}$.

135 Там само. С. 251.

${ }^{136}$ Ожегов С. И. О трех типах толковых словарей современного русского языка. Вопр. языкознания, 1952. № 2. С. 85.

${ }^{137}$ Паламарчук Л. С. Тлумачний словник української мови в колі слов'янських словників цього типу: доповідь на VII Міжнародному з'їзді славістів (Варшава, серпень 1973 р.). К.: Наук. думка, 1973. С. 9. 
Таким чином, поданням термінолексики, що міститься в шкільних підручниках, тлумачна лексикографія не обмежується, а тому «...із спеціальної лексики різних наук, техніки й виробництва словник включає терміни, що ввійшли в підручники з відповідних наук загальноосвітньої середньої школи, а так само й інших наук, хоч вони й не викладаються в загальноосвітній середній школі, але термінологія яких вживається в науково-популярній (не фаховій) літературі і в загальній пресі і взагалі ширше використовується як у книжній, так і в усній мові (в доповідях, передачах, радіо та ін.)»» ${ }^{138}$.

Зараз, крім описаних Л. Паламарчуком джерел, межі функціонування термінології значно розширив й Інтернет. Та й науково-популярна, навчальна література 3 плином часу суттєво змінилася, оскільки ускладнилися загальноосвітні програми, з'явилися нові галузі знання, які тісно пов'язані із сьогоденням переважної більшості людей. Активно проникають у побут поняття економічної сфери, інформатики, медицини, генетики тощо.

Після виходу першого тому Словника української мови у 20-ти томах дехто 3 критиків звинувачував його укладачів у невиправданому введенні до реєстру деяких термінологічних одиниць і недотриманні основних критеріїв подання фахової лексики. Дійсно, думки щодо потрібності того чи того терміна в загальномовній лексикографічній праці можуть бути різними й часто протилежними.

Скажімо, Л. Боярова вважає, що настанова подавати тільки широковживані спеціальні мовні одиниці не може бути на сьогодні визначальною для кодифікування термінологічної лексики в загальномовному словнику. Тому що, 3 одного боку, на початок XXI ст. у національній термінології з'явилася велика кількість нових термінологічних назв, що мають бути відомими освіченій людині, але які ще не поширені в популярній та художній літературі, пресі тощо. 3 другого, - до цього часу у сфері функціонування фахової мови часто вживають кальки й запозичення 3 російської мови, що дублюють питомі терміни і які 3 погляду сучасної теорії термінотворення не потрібно кодифікувати в українській

${ }^{138}$ Там само. С. 9. 
лексикографії. Проаналізувавши реєстри багатьох новітніх словникарських праць тлумачного типу, Л. Боярова дійшла до висновку, що терміни добирають і фіксують за критерієм їхньої поширеності в багатьох випадках суб'єктивно й непослідовно: термінологічні мовні одиниці, які одні лексикографи вважають часто вживаними й такими, що їх треба подати в словнику, інші розглядають як вузькоспеціальні ${ }^{139}$.

Схожим із позицією Л. Боярової є запропонований критерій сучасності Л. Щерби. Згідно з ним у загальномовній тлумачній лексикографії потрібно кодифікувати не лише актуальні терміни, що функціонували давно, а й деякі неологізми, що з'являються в термінологічному просторі. Неологізми в словнику потрібні для унаочнення сучасних змін у мові, пов'язаних зі змінами в структурі суспільства, у матеріальній та духовній його культурі ${ }^{140}$.

Деякі дослідники вважають, що до реєстру словника варто вводити не тільки терміни, які усталилися в терміносистемі, але й їхні варіанти, дублети й синоніми, а також значення всіх багатозначних слів. На нашу думку, фіксувати в реєстрі словника дублети, синоніми недоцільно, оскільки, з одного боку, за їх рахунок значно збільшиться обсяг словника, а з другого - порушиться одна 3 основних засад словника - його нормативність.

Ураховуючи розглянуті міркування, основні чинники розвитку термінолексики і власний словникарський досвід, виокремлюємо три основні вимоги, якими повинен керуватися лексикограф, уводячи термінологію до реєстру великого тлумачного словника: 1) варто звертати увагу на частотність вживання фахових слів (у реєстрі загальномовного словника все-таки не бажана вузькоспеціальна лексика). Загальногалузеві та міжгалузеві терміни мають бути максимально представлені в загальномовних словниках, місце ж вузькогалузевих термінів - у галузевих словниках ${ }^{141} ; 2$ ) репрезентативність (по можливості має

139 Боярова Л. Термінологічна лексика в загальномовному тлумачному словнику. Лексикографічний бюлетень. К., 2008. Вип. 17. С. 13-24.

${ }^{140}$ Щерба Л. В. О словарях живого литературного языка. Современная русская лексикология. М.: Наука, 1966. С. 75.

${ }^{141}$ Симоненко Л. О. Термін у загальномовних словниках. Українська і слов'янська тлумачна та перекладна лексикографія. Леонідові Сидоровичу Паламарчукові. К.: КММ, 2013. C. 220 . 
бути зафіксована термінологія різних галузей знань у тому співвідношенні, у якому іiі використовують пересічні мовці) та 3) обов'язково потрібно враховувати авторитетність джерела (достовірна науково-популярна, навчальна література; у деяких випадках задля об'єктивності можна залучати й наукові тексти).

Особливої уваги потребує введення до реєстру термінів, які перебувають на протилежних полюсах терміносистеми: неологізми, терміни, що втратили свою актуальність, а також критичний підхід до термінологічних надбань доби українізації $20-\mathrm{x}$ - початку $30-\mathrm{x}$ років XX ст. Поповнення українського термінофонду неологізмами створює певну проблему словникарям у плані освоєння нових запозичень, їх пристосування до різних терміносистем. Найдискусійнішою в українському мовознавстві залишається проблема словотвірного освоєння нових запозичень ${ }^{142}$, оскільки навіть у різних новітніх словниках спостерігається різнобій у написанні (он-лайн - онлайн; попмузика поп-музика, бодібілдинг - бодибілдинг, бодигард - бодігард та ін.). Оновлення наукової термінології об'єктивно відтворює багатоступеневий процес пізнання.

Крім принципів добору термінологічної лексики, укладачі тлумачних словників вирішують питання розроблення тлумачень цих одиниць. Філологічний словник зіштовхується «...3 потребою тлумачити (і тлумачити науково, тобто визначати) наукові поняття» ${ }^{143}$, що проникають «...у заповідні зони власне літературної й загальної мови як частини мовної семантики в тій мірі, у якій $є$ «мовною» семантика відображення» ${ }^{144}$.

На відміну від енциклопедичних словників, які досить широко залучають до своїх реєстрів широковживану, фахову й спеціальну термінологію, що функціонує в багатьох галузях науки, культури, знання, і пропонують стисле, але вичерпне наукове визначення кожного терміна, «...у словниках загальної мови в тлумаченні

${ }^{142}$ Городенська К. Г. Нові запозичення і новотвори на тлі фонетичної та словотвірної підсистем української літературної мови. Українська термінологія і сучасність: збірник наукових праць. К.: КНЕУ, 2009. Вип. VIII. С. 3-4.

${ }^{143}$ Кутина Л. Л. Термин в филологических словарях (к антитезе: энциклопедическое филологическое). Проблематика определений терминов в словарях разных типов. Л.: Наука, 1976. С. 22.

144 Там само. С. 22. 
слів підкреслюють ті ознаки предмета, дії чи процесів, які найбільш явно виявляються в звичайному житті людей. Коли люди вживають слово, вони помічають у відповідному «референті» ознаки, опис яких у тлумаченні відповідного слова дає нам уявлення про узагальнений образ, який стоїть за певним звуковим (орфографічним) комплексом» ${ }^{145}$. Дефініція терміна, залишаючись цілком науковою, повинна вказати лише на ті суттєві ознаки, які виділяють окремий термін у його термінологічній системі. Л. Кутіна зауважує, що «...основна мета загальнолітературних словників знайти саме той мінімум, у межах якого дефініція наукова (достатня), але не енциклопедична (тобто містить лише ознаки, необхідні для виділення поняття в системі)» ${ }^{146}$.

Значна частина термінологічних одиниць зафіксована в академічних Словниках української мови в 11-ти й 20-ти томах, які $є$ найповнішими зібраннями лексики української мови від часів І. Котляревського до наших днів. Нагадаємо, що на сьогодні вже $є$ дев'ять томів паперового варіанта двадцятитомного словника, інші буде видрукувано впродовж найближчих років.

Порівняння реєстрів багатотисячних тлумачних лексикографічних праць різних часових періодів дозволяє спостерігати процес розвитку як лексики окремих галузей знань, так і термінофонду мови в цілому. Тому матеріалом дослідження послугував тлумачний Словник української мови у 20-ти томах (http://corp.ulif.org.ua/xdictua/) і Словник української мови в 11-ти томах, що $є$ електронними базами даних Українського мовно-інформаційного фонду НАН України. Створені комп'ютерні версії словників сьогодні уможливлюють проведення комплексних досліджень окремих груп лексики, зокрема й термінологічної.

Отже, термінологічна лексика на сучасному етапі розвитку науки $\epsilon$ невід’ємним складником тлумачної лексикографії, оскільки значна кількість іï активно функціонує не тільки у фаховій літературі, а й у загальномовному вжитку.

145 Журавлева Т. А. Особенности терминологической номинации. Донецк: Донбасс, 1998. C. 56.

${ }^{146}$ Кутина Л. Л. Термин в филологических словарях (к антитезе: энциклопедическое филологическое). Проблематика определений терминов в словарях разных типов. Л.: Наука, 1976. С. 22. 
Її аналіз у СУМ-11 та СУМ-20 дозволяє простежити еволюцію основного термінологічного складу української мови. Це дослідження $є$ ефективним для комплексного системного вивчення різних змін і процесів у термінології за певний період.

\subsection{3. Питання про частиномовну належність фахової лексики. Терміни-прислівники в тлумачній лексикографії}

Однією з термінологічних проблем є питання про частиномовне вираження термінів. У лінгвістичних працях поширена думка про іменниковий характер термінології. За твердженням О. Реформатського, найхарактернішою ознакою термінологічної лексики є її належність до категорії іменника. Однак дослідник не заперечував можливості позначати поняття наукової сфери й іншими частинами мови за відсутності синонімічних іменників ${ }^{147}$. Думку про майже цілковиту належність термінів до лексико-граматичного класу іменників підтверджують й інші науковці ${ }^{148}$.

Протилежний погляд на частиномовне вираження термінологічної лексики має В. Даниленко, яка стверджує, що граматичним «фондом» термінології «...є повнозначні слова: іменники, прикметники, прислівники, дісслова» ${ }^{149}$. У своїх працях дослідниця доводить здатність інших частин мови виконувати функції термінів: «Думка про непридатність прикметників виступати в статусі термінів на тій основі, що вони в мовленні не вживаються абсолютивно, не можна вважати переконливою, оскільки вказана відмінність не $\epsilon$ ознакою прикметників у термінології. Це - ознака цієї частини мови, незалежно від сфери вживання» ${ }^{150}$. Проте, як показують спостереження, й серед прикметників є такі, що мають самостійне значення.

${ }^{147}$ Реформатский А. А. Мысли о терминологии. Современные проблемы русской терминологии. М., 1986. С. 163-198.

${ }^{148}$ Науково-технічний прогрес і мова / відп. ред. В. М. Русанівський. К.: Наук. думка, 1978. C. 81.

149 Даниленко В. П. Русская терминология: Опыт лингвистического описания. М., 1977. C. 37.

150 Даниленко В. П. Русская терминология: Опыт лингвистического описания. М., 1977. C. 43 . 
У реєстрах багатьох термінологічних та загальномовних перекладних i тлумачних словників також наявна фахова лексика, що належить до різних повнозначних частин мови (крім займенників і числівників).

Підтвердження думки про придатність й інших частин мови, крім іменників, позначати спеціальні поняття проілюструємо на прикладі прислівникової термінології, зафіксованої в СУМ-11 і СУМ-20.

На відміну від прикметників, прислівники-терміни не входять до складу термінологічних словосполучень і тому можуть розглядатися як окремі, не пов'язані з іменниками, одиниці певної терміносистеми.

У складі СУМ-11 прислівники-терміни займають близько 1,6\% від усіх зафіксованих прислівників (загалом їх у словнику понад 6 тис.). Це переважно відприкметникові утворення із суфіксом -о. Найбільше прислівникової термінології нараховується серед фахової лексики таких галузей знань:

1) математики: алгебраїчно, алгебрично, арифметично, геометрично, математично, перпендикулярно, планіметрично, сферично тощо;

2) лінгвістики, літературознавства: граматично, евфонічно, етимологічно, метафорично, морфологічно, орфоепічно, предикативно, публічистично, риторично, синтаксично, стилістично, текстологічно, філологічно тощо;

3) біологічних наук: аритмічно, біологічно, вегетативно, генетично, партеногенетично, репродуктивно, рефлекторно, фізіологічно тощо;

4) суспільно-економічних наук: історично, ліберально, матеріалістично, монопольно, регресивно, рентабельно, самодержавно, сепаратно, соиіалістично тощо.

Окрему групу термінів у СУМ-11 становлять непохідні прислівники, що мають самостійні, не залежні від прикметникових, значення. Сюди належать іншомовні слова з музичної та поліграфічної галузей.

У музикознавстві - це назви музичних темпів, способів, манери виконання музичних творів і т. ін.: адажіо (повільно, протяжно), алегрето (помірно швидко), анданте (повільно, плавно), кантабіле (співучо), крещендо (поступово збільшуючи силу звуку; дедалі гучніше), легато (плавно переходячи від однієї 
ноти до іншої), піанісимо (дуже тихо, ще тихіше, ніж піано), піано (тихо), форте (сильно, гучно), фортисимо (дуже сильно, гучно, голосніше, ніж форте) тощо.

Поліграфічні терміни, наявні в СУМ-11, уживаються на позначення назв форматів, наприклад: ІН-КВА́РТО, присл. У четверту частину аркуша (про формат книжки, журналу, рукопису); у чверть. ІН-ОКТА́ВО, присл. У восьму частину аркуша (про формат книжки, журналу, рукопису); у вісімку. ІН-ФО́ЛІО, присл. В аркуш, зігнутий навпіл (про формат книжки, журналу).

У Словнику української мови у 20-ти томах натепер міститься близько восьми тисяч прислівників. Терміни становлять 1,2% від загальної їх кількості. Але порівняно із СУМ-11 їх удвічі більше.

Термінів-прислівників, що утворені від прикметників, найбільше нараховують такі галузі:

1) лінгвістика: артикуляційно, аспектологічно, гіперонімічно, гіпонімічно, лексикографічно, лексично, фразеологічно тощо;

2) медицина: внутрішньовенно, внутрішньоклітинно, внутрішньом'язово, внутрішньосериеев, спазмолітично тощо;

3) біологічні науки: анатомічно, апогамно, внутрішньоклітинно, генотипно, небіогенно тощо;

4) математика, фізика, хімія: алгоритмічно, барицентрично, баріонно, внутрішньомолекулярно, гідролітично, дифузно тощо.

Із самостійними значеннями в СУМ-20 зафіксовано прислівники-терміни, що належать до музичної сфери (АЖИтА́ ТО, присл., муз. Збуджено, схвильовано; АНДАНТи́нО, муз. 1. присл. Повільно, дещо швидше, ніж анданте (про темп виконання музичного твору); АНІМА́ТО, присл., муз. Натхненно, жваво; АПАСІОНА́ТО, присл., муз. Пристрасно, натхненно (про характер виконання музичного твору або його частини); ВІВА́ЧЕ, муз. 1. присл. Швидко, жваво (про темп виконання музичного твору, швидший від алегро, але повільніший від престо); ВІ́ВО, присл., муз. Жваво, швидко (про темп виконання музичного твору, близький до віваче); ЕЛЕВА́ТО, присл., муз. Піднесено; МЕ́ЦО-ПІА́НО, присл., муз. Помірно тихо, трохи голосніше, ніж піано, МЕ́ЦО-ФО́РТЕ, присл., муз. Помірно голосно, трохи тихіше, ніж форте). 
Отже, проаналізований матеріал переконливо засвідчує придатність не лише іменників, а й інших повнозначних частин мови, зокрема прислівників, виконувати функції термінів. Навіть у загальномовних тлумачних словниках, які фіксують тільки найпоширеніші терміноодиниці, що вживаються в мові, терміниприслівники у складі багатьох галузей знань посідають помітне місце і є не лише поодинокими відприкметниковими утвореннями. Більше того, у деяких наукових сферах, наприклад у музикознавстві, виступають ще й одними з основних понять.

Результати дослідження підтверджують думку, що термінами можуть бути не лише іменники, а й прикметники, дієслова, прислівники, хоча їх, безперечно, значно менше, ніж субстантивів.

\section{2. Термінологічна лексика в Словниках української мови в 11-ти та 20-ти томах}

\subsection{1. Інструментальний комплекс «Словник української мови» в системі опрацювання термінології}

Розглянемо детальніше процес відбору галузевої лексики з використанням інструментального комплексу «СУМ».

Для експлікації ремаркованої лексики (рис. 18.1) відкриваємо реєстр Словника (на рисунку СУМ-11), потім натискаємо вікно «Вибір», знаходимо пункт «Стилістичні ремарки» (усі ремарки було занесено в базу даних), обираємо потрібну (наприклад, мед. - медицина). Після цього відкривається реєстр термінів із цією ремаркою й унизу зазначається кількість таких одиниць (у нашому випадку це 394 слова). Таким чином було відібрано ремарковану термінологію з кожної, зафіксованої у Словнику, галузі знань.

Оскільки функції базового інструментального комплексу не дозволяли здійснювати пошук неремаркованої лексики, для їі дослідження було розроблено нову функцію, яка передбачає пошук за ключовими словами - ідентифікаторами термінів, що містяться в тлумаченнях (рис. 18.2). Зрозуміло, що після такого відбору в реєстр потрапляла не тільки термінологія, тому масив слів було проаналізовано, вибрано необхідні одиниці й поділено їх за галузями знань. 


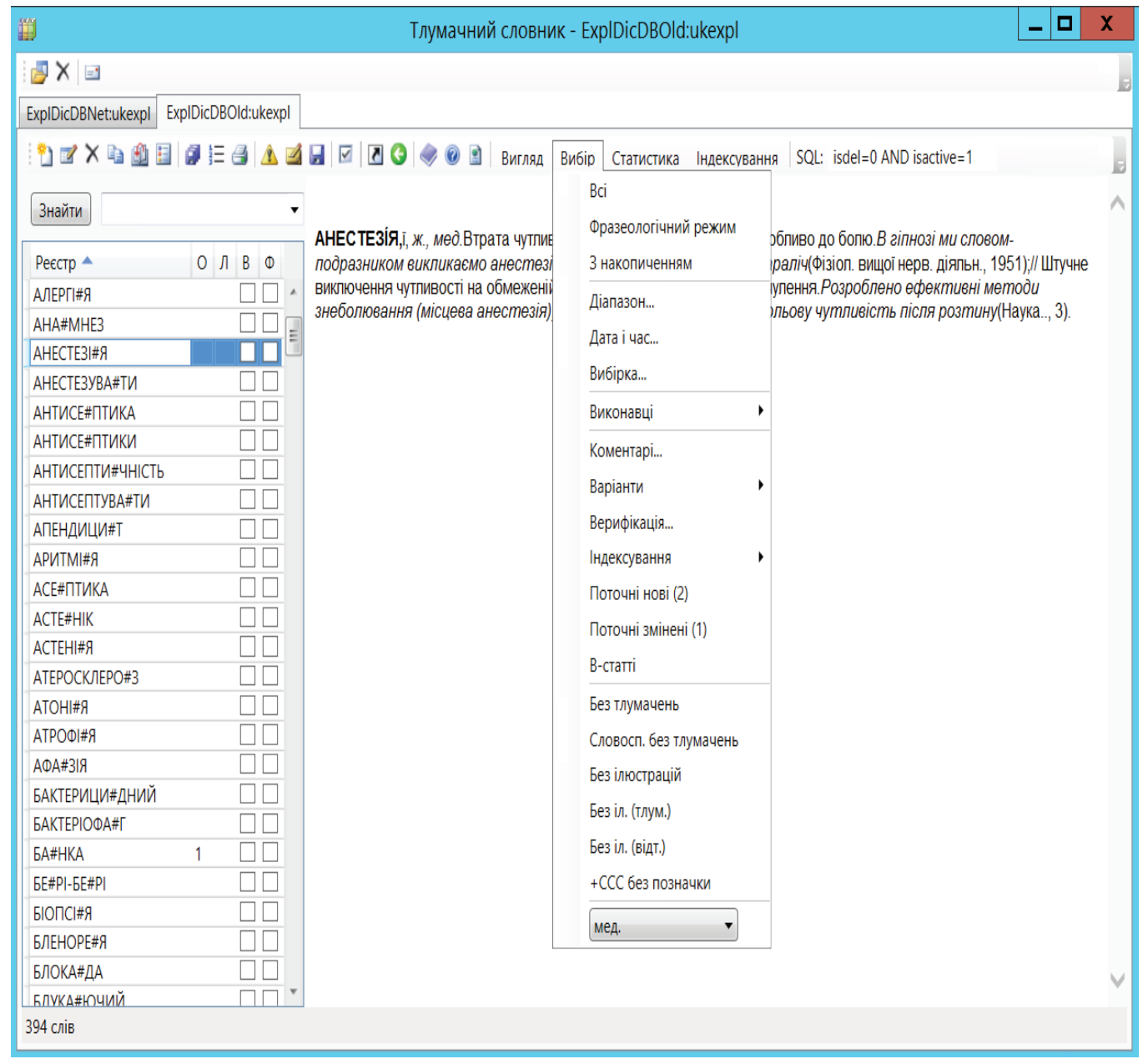

Рис. 18.1. Вибір термінів за ремарками 


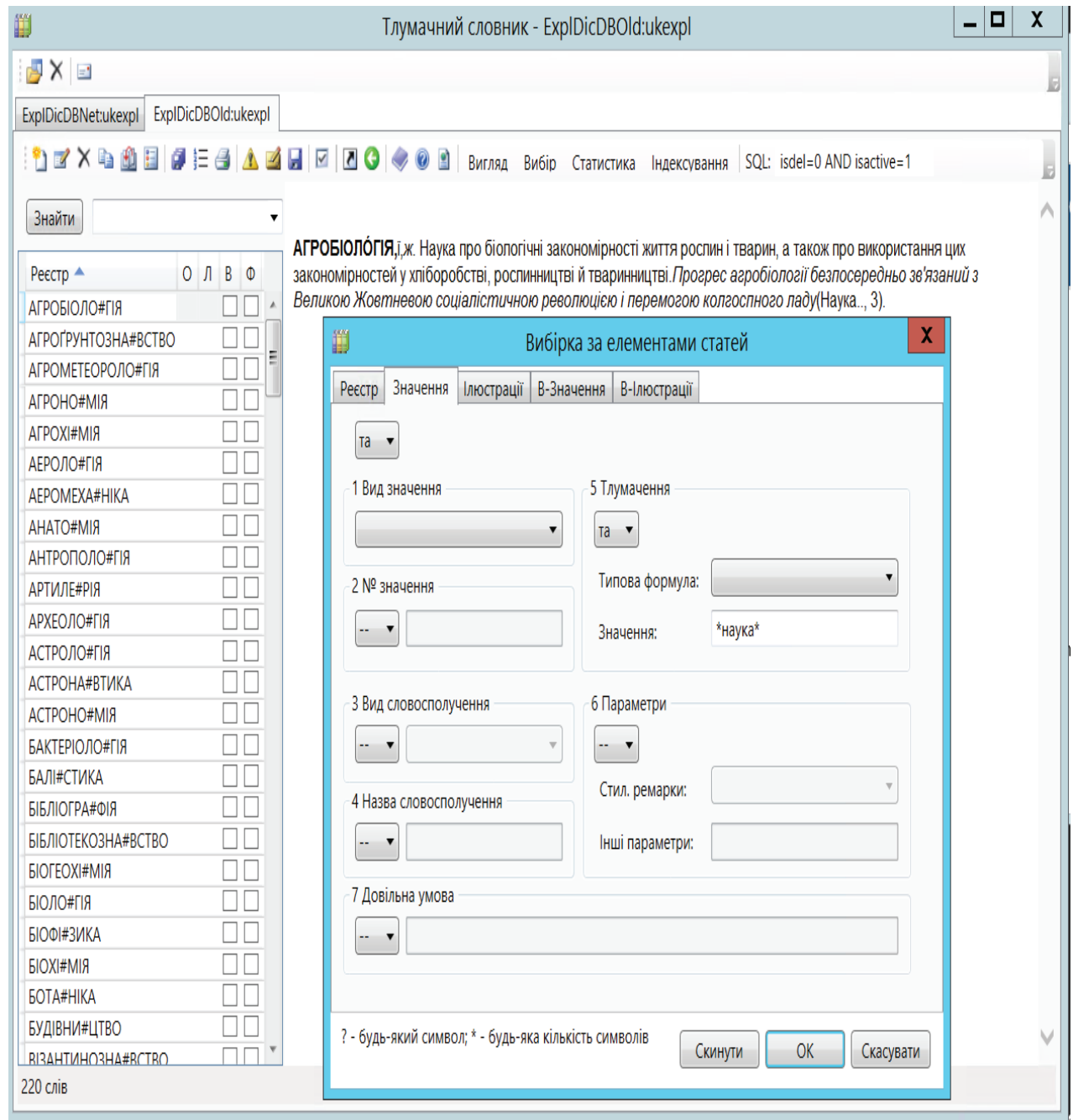

Рис. 18.2. Вибір термінів за пошуковими словами, що містяться в дефініціях

Отже, створені додаткові функції інструментального комплексу допомогли якнайповніше відібрати термінологічну лексику для дослідження. 


\subsection{2. Класифікація галузевої термінології. Тематичні групи слів}

Термінологія сучасної української літературної мови досить багата й розгалужена відповідно до наявних у нинішньому суспільстві знань. В. Русанівський усю термінолексику поєднав у такі групи: 1) наукова; 2) суспільно-політична; 3) суспільно-економічна; 4) юридична ${ }^{151}$.

Детальніший поділ термінології можемо знайти в монографії «Сучасна українська літературна мова. Лексика і фразеологія» (за редакцією І. К. Білодіда). У їі складі виділено велику групу суспільно-політичної термінологічної лексики, з якою семантично споріднена група слів на позначення понять зі сфери різних суспільних наук: економічна, філософська, логічна, психологічна, педагогічна, історична, юридична, дипломатична, фінансова, офіційно-ділова термінологія. У групі термінологічної лексики української мови виокремлено літературознавчу й лінгвістичну термінологію. Дуже розгалужена термінологія мистецька й мистецтвознавча, до якої належить лексика: музична, театральна, кіномистецька, образотворчого мистецтва, архітектурна. Розвинена фізико-математична, природнича, геолого-географічна й технічна термінологія. У складі наукової термінологічної лексики розрізняється, наприклад, термінологія математична, фізична, хімічна, біологічна, фізіологічна, ботанічна, зоологічна, географічна, геологічна, астрономічна. У технічній лексиці виокремлено гірничу, металургійну, машинобудівну, електротехнічну, гідротехнічну, зварювальну, радіотехнічну термінологію. Розвинена також термінологія сільськогосподарська, медична, спортивна, військова, авіаційна тощо ${ }^{152}$.

Розвиток термінології різних галузей знання схарактеризовано в монографії «Склад і структура термінологічної лексики української мови». Це дослідження демонструє картину сучасної наукової термінолексики, створеної достатнім обсягом термінів і термінологічних сполук, що охоплюють усі розділи й дисципліни сучасних наук, відбивають семантику сучасних соціальних інститутів:

${ }^{151}$ Русанівський В. М. Структура лексичної і граматичної семантики. К.: Наук. думка, 1988. C. 169.

152 Сучасна українська літературна мова. Лексика i фразеологія / за заг. ред. І. К. Білодіда. К.: Наук. думка, 1973. С. 163-164. 
матеріального виробництва, техніки, науки, політики, права, моралі, мистецтва, освіти, релігії, культури. У цю систему входить також загальнонаукова термінологія, яка не має спеціальної прив'язаності до окремої галузі знань і вживається взагалі в науковому стилі (лабораторія, наука). До термінолексики входять назви циклів, розділів наук та їхніх окремих дисциплін, а також найменування спеціалістів у межах цих наук. Зміст термінів надзвичайно різноманітний, оскільки вони охоплюють усі поняття наукової, виробничотехнічної сфери людської діяльності ${ }^{153}$.

Часто термінологічну лексику розглядають у складі таких груп: термінологія природничих наук, технічних, суспільних i гуманітарних, кожна 3 яких розподілена за галузями.

Дослідження термінології передбачає розгляд їі не тільки як цілісного системного утворення, але й на рівні окремих елементів (частин) цілого, тобто в складі термінологічних підсистем, а в їхніх межах - відкритих об'єднань номінацій - тематичних груп. Підставою для виділення тематичних груп слугує поняттєвий (екстралінгвальний) принцип, а саме предметно-логічний зв'язок між поняттями, позначуваними словами тематичної групи. Відбиваючи певним чином ті чи ті «відрізки дійсності», слова, звичайно, пов’язані між собою, як взаємопов’язані й відображувані ними явища самої дійсності. Завдяки цим «позамовним» зв'язкам слова поєднуються в групи, які можна назвати тематичними $^{154}$. «Сдність елементів тематичних груп, - зауважує Е. Кузнецова, визначається насамперед денотативним фактором, спільністю самих явищ. Семантичні зв’язки між словами в межах таких груп доволі різноманітні: частина й ціле, функціональні зв'язки предметів, а також родо-видові відношення» ${ }^{155}$. За такого підходу термінологічна лексика в тлумачному словнику отримує системний опис, що полягає у виявленні й репрезентації зв'язків і відношень між словами в межах тематичних груп. Розкриваються такі типологічні особливості

${ }^{153}$ Склад і структура термінологічної лексики української мови / [А. В. Крижанівська, Л. О. Симоненко, Т. І. Панько та ін.]; за ред. А. В. Крижанівської. К.: Наук. думка, 1984. С. 27.

${ }^{154}$ Шмелев Д. Н. Очерки по семасиологии русского языка. М.: Просвещение, 1964. С. 130.

${ }^{155}$ Кузнецова Э. В. Лексикология русского языка: учеб. пособие для филол. фак. ун-тов. 2-е изд., испр. и доп. М.: Высш. шк., 1989. С. 71. 
досліджуваного матеріалу, які дозволяють з'ясувати характерні особливості терміносистем, проінтерпретувати актуальні для термінології шляхи й тенденції розвитку.

Отже, усю зафіксовану й відібрану $з$ лексикографічної бази даних термінолексику було поділено за виокремленими в словниках галузями знань, а в межах кожної терміносистеми - за тематичними групами.

\subsection{3. Класифікація термінології Словника української мови в 11-ти томах та розширення її складу в Словнику української мови у 20-ти томах}

Із наукових праць українських дослідників відомо, що реєстровий склад Словника української мови в 11-ти томах відтворює більшу частину активно вживаної термінології 50 - 70-х років XX століття. 3 погляду лексико-стилістичної характеристики в Словнику виділяють такі групи термінів: 1) термінолексика науки; 2) термінолексика техніки та виробництва; 3) термінолексика управління; 4) термінолексика культури та спорту ${ }^{156}$.

Для ідентифікації термінів у Словнику української мови в 11-ти томах використано змішану систему як стилістичної характеристики, так і власне ремаркування. Функціонально-стильову характеристику галузевої лексики подано в СУМ двома способами: 1) через текст тлумачення, з якого випливає та вужча галузь діяльності, у якій уживається відповідне слово; 2) через додавання до тлумачення відповідної вказівки: ремарки (загальної або галузевої) чи спеціальної вказівки в тексті тлумачення ${ }^{157}$.

За спостереженням В. Балог, функціонально-стильовий супровід у вигляді ремарки простежується переважно при словах - термінах науки (крім

${ }^{156}$ Балог В. О. Галузева лексика в Словнику української мови в 11-ти томах (1970-1980 pp.) (семантичний та стилістичний аспекти): автореф. дис. на здобуття наук. ступеня канд. філол. наук: спец. 10.02.01 «Українська мова». К., 2003. С. 5.

${ }^{157}$ Балог В. О. Галузева лексика в Словнику української мови в 11-ти томах (1970-1980 pp.) (семантичний та стилістичний аспекти): автореф. дис. на здобуття наук. ступеня канд. філол. наук: спец. 10.02.01 «Українська мова». К., 2003. С. 12. 
загальнонаукових), техніки та виробництва. Меншою мірою ремаркованою $\epsilon$ термінологічна лексика суспільної сфери ${ }^{158}$.

Ремарки та ключові слова (про які вже згадувалося вище) допомогли якнайповніше ідентифікувати терміноодиниці всіх галузей знань, які зафіксовані в словнику. Хоча, як і в будь-якому дослідженні, можливі похибки. Вони можуть бути через такі причини: 1) не вся галузева лексика маркована; 2) перелік ключових слів може бути неповним; 3) до того ж, як відомо, у сучасному термінознавстві до цього часу немає чіткого розмежування термінологічної й нетермінологічної лексики. Проте всі названі недоліки суттєво не впливають на загальний результат дослідження, яке без комп’ютерних технологій було б дуже складно здійснити.

Отже, усього термінологічних одиниць в реєстрі Словника української мови в 11-ти томах нараховується понад 13,5 тисяч (близько $10 \%$ від усіх слів). Наголосимо, що статистика стосується лише термінослів. Термінологічних словосполучень до уваги не взято, вони будуть об'єктом подальших досліджень.

Щодо галузевої належності, то в СУМ-11 зафіксовано термінологію сімдесяти галузей (подаємо за частотністю): історія, техніка, медицина, ботаніка, сільськогосподарська термінологія, лінгвістика, музика, фізика, геологія, біологія, хімія, математика, військова термінологія, спорт, політика, анатомія, юриспруденція, граматика, літературознавство, морська термінологія, радіотехніка, філософія, будівництво, орнітологія, релігієзнавство, зоологія, металургія, економіка, гірництво, етнографія, друкарство, фізіологія, іхтіологія, мистецтво, текстильна термінологія, фінанси, астрономія, авіація, кулінарія, ентомологія, електрика, ветеринарія, садівництво, архітектура, мисливство, геодезія, театральна термінологія, міфологія, географія, логіка, фармацевтика, фотографія, бухгалтерські терміни, археологія, кравецька термінологія, метеорологія, психологія, залізнична термінологія, гідрологія, живопис, дипломатична термінологія, механіка, антропологія, кінематографія, рибальська термінологія, столярство, бактеріологія, біохімія, канцелярська термінологія,

${ }^{158}$ Там само. С. 5. 
соціологія. Крім названих терміносистем, СУМ-11 налічує понад три тисячі одиниць різногалузевої лексики (належить більше ніж до трьох галузей знань і має ремарку «сnеu.»).

Кількісно й тематично найширшими в Словнику української мови в 11-ти томах є такі галузі: історія ( $\approx 7 \%$ від усіх термінів), медицина ( $\approx 4,67 \%)$, анатомія $(\approx 1,6 \%)$, лінгвістика $(\approx 3 \%)$, фізика $(\approx 2,44 \%)$, сільське господарство $(\approx 3,44 \%)$. У межах кожної з них можна виділити значну кількість тематичних груп (близько десяти). Суттєву частину термінологічної лексики мають також галузі, у складі яких нараховується 6-5 тематичних груп. Саме ці найбільші за кількістю реєстрових одиниць (не менше ста) та тематичних груп (не менше п'яти) терміносистеми й будуть об'єктом нашого дослідження в цьому розділі.

Для відтворення картини функціонування й розвитку термінологічної лексики в сучасній українській мові проведемо іï порівняльний аналіз у двох лексикографічних системах - СУМ-11 і СУМ-20. Розглянемо поповнення двадцятитомного словника новою термінологією, що відбиває сучасний рівень еволюції науки, з'ясуємо іiі кількісні та якісні зміни порівняно 3 одинадцятитомною працею.

Значну частину реєстру Словника української мови у 20-ти томах (близько 23,6 \% від усіх доданих слів) становлять одиниці - нові терміни на позначення понять різних галузей науки, а особливо медицини ( $\approx 10,80 \%)$, історії $(\approx 6,62 \%)$, біології $(\approx 6,54 \%$ ), геології $(\approx 5,73 \%)$, хімії $(\approx 4,76 \%)$, фізики $(\approx 4,15 \%)$, лінгвістики $(\approx 3,73 \%)$, інформатики $(\approx 2,85 \%)$ тощо. Менше додано терміноодиниць ботаніки, математики, фінансової галузі, спорту, економіки, музики, зоології, юриспруденції, ветеринарії, фармацевтики, релігієзнавства, фізіології, сільського господарства, літературознавства, політики, філософії, психології, анатомії ( $\approx 2,8-1 \%$ ). Лексика кількох галузей знань (спеціальна термінологія) становить $\approx 11 \%$ від усіх нових термінів двадцятитомника. Загалом СУМ-20 поповнився приблизно на 12 тисяч терміноодиниць. Отже, усього двадцятитомний словник натепер містить понад 25 тисяч термінів (близько $14 \%$ від усіх слів). 
Зауважимо, що навіть після опублікування чергового тому Словника, робота над поповненням його реєстру (комп’ютерної версії) не припиняється. Зокрема, лексикографи додають пропущені слова, наявні в тлумаченнях й ілюстраціях, високочастотні лексеми тощо. Тому, зрозуміло, що до виходу останнього тому цієї лексикографічної праці кількість термінологічної лексики може дещо змінитися. Проте значних перетворень не очікується, оскільки основний реєстр уже сформовано й відбувається переважно лише редагування укладених статей.

Виняток становлять тлумачення до реєстрових одиниць і термінів зокрема. Вони можуть дещо змінитися. Тому в своєму дослідженні намагатимемося наводити приклади з уже опублікованих томів. А ось суттєвих змін у реєстрі варто очікувати, напевно, після опублікування всіх книг, після виходу яких (а, може, й раніше) суспільство повністю відмовиться від паперових словників. Популярними стануть і матимуть попит (та вже й мають) цифрові словники, які фіксуватимуть нову лексику постійно.

Щодо фахової термінології в Словнику української мови в 11-ти томах, то найчисленнішою тут є історична лексика, яка містить велику частину іменників на позначення осіб, організацій, давньої зброї, грошей тощо.

На відміну від інших (зафіксованих у СУМ-11) царин, в історичній галузі нараховується багато абревіатур, що виникли й активно функціонували переважно в якийсь період радянської епохи: (ВКП(б), icm. Абревіатура: Всесоюзна Комуністична партія (більшовиків), ВУЦВК, невідм., ч., icm. Скорочення: Всеукраїнський Центральний Виконавчий Комітет, КІМ, У, ч., icm. Скорочення: Комуністичний Інтернаціонал Молоді, КОМБІ́Д, у, ч., icm. Скорочення: комітет бідноти, ПОВІТКО́М, у, ч., icm. Скорочення: повітовий комітет та багато інших.

Частину історичних понять витлумачено відповідно до тодішніх ідеологічних настанов, наприклад: МАХНО́ВЕЦь, вця, ч., icm. Той, хто належав до контрреволюційної банди отамана Махна; ДИРЕКТо́РІя, ї, ж., icm. Назва деяких урядів, наприклад у Франції в епоху буржуазної революції (1795-1799рр.), контрреволюційного уряду на Україні (1918-1919 рр.); СТОЛИ́ПІНЩИНА, и, ж., іст. У Росії - дворянсько-кріпосницька реакція періоду 1907-1910 рр., що 
характеризувалася зміцненням куркульства i жорстоким придушенням революційних сил тощо.

У складі історичної термінологї̈ багато прикметників, які мають самостійні значення, менше - відсубстантивних (статті 3 описовими та відсилковими тлумаченнями). Зокрема, із самостійним значенням через розгорнуту формулу тлумачення подано, наприклад, такі прикметники: АРИСТОКРАТЙЧНИЙ, a, е. ... 3. icm. Який характеризується панівною роллю аристократії (в 2 знач.); БЕЗСТА́НОВИ́Й, а́нова́, áнове́, icm. Який не належить ні до якого стану; не пов'язаний 3 належністю до якогось стану, однаковий для всіх станів; МУРОЛО́МнИй, a, e, icm. Признач. для руйнування фортечних стін (про давні гармати); ПОСПОЛи́тИй, а, е. 1. icm. На Україні до Народно-визвольної війни 1648-1654 рр. та в перші роки після неї - належний до міщан або до селянства, згодом, у другій половині XVII-XVIII ст., - належний до селян. Відсилкові статті формулюються через посилання на відповідні іменники, наприклад: ІНКВІЗЙТОРСБКИЙ, а, е. 1. icm. Прикм. до інквізи́тор 1; КАСО́ЗБКИЙ, a, е, icm. Прикм. до касо́ги тощо.

Дієслівна лексика зазначеної галузі нечисленна, хоча певну кількість таких одиниць у СУМ-11 зафіксовано. Це переважно дієслова, що означають «бути кимсь, виконувати якусь роботу»: гайдамакувати, гетьманувати, князювати, опришкувати, а також дієслівні одиниці на позначення дій панівної особи (організації) щодо підлеглої особи (осіб): відпускати, закріпачувати, порозкуркулювати, розкріпачувати тощо.

Загалом у термінологічній лексиці 3 історії можна виділити десять тематичних груп:

1. Назви осіб: асесор, бакалавр, бард, баскак.

2. Найменування організацій, установ: бунд, комбід, комнезам, управа.

3. Назви предметів-символів: бунчук, орифлама, скіпетр.

4. Назви зброї: органка, топір, ядро.

5. Назви грошей: асигнація, векша, дукат, лев, лівр, півкопійки.

6. Найменування письмових джерел: пролог, хроніка, ярижка.

7. Назви документів: статут, чолобитна, ярлик. 
8. Найменування одягу, взуття: котурни, ментик, илик, шуглон.

9. Назви видів діяльності: гетьманувати, князювати, опришкувати.

10. Назви дій одних осіб щодо інших: закріпачувати (закріпачити), рекрутувати, порозкуркулювати.

У Словнику української мови у 20-ти томах кількість історичних термінів збільшилася майже вдвічі (порівняно зі Словником української мови в 11ти томах). Одним зі шляхів поповнення лексики стало розширення реєстру СУМ-20 за рахунок слів на позначення об'єктів, явищ, понять, осіб тощо, які належать до всесвітньої історії та до історії України різних часових періодів, що існували, але не були зафіксовані в СУМ-11. Наприклад: АГО́РА, и, ж., icm. Торгова площа і місце народних зібрань у давньогрецьких містах; АЇЛ, у, ч. 1. icm. У киргизів та алтайців у минулому - селище кочівників, звичайно населене членами однієї родини. 2. $\mathrm{icm}$. У монгольських народів - кочова сімейна група; БЕ́РІЇВЩИНА, и, ж., $і \mathrm{~cm}$. Злочинна система масових незаконних репресій в СРСР під час перебування Л. П. Берії на посаді народного комісара внутрішніх справ (1938-1945рр.); БУЛАНЖИ́ЗМ, у, ч., icm. Рух у Франції в кінці ХІХ ст., метою якого було встановлення військової диктатури; ГЕДи́СТ, а, ч., icm. Прихильник політичної течії у французькому робітничому русі в кінці XIX - на початку ХХ століття, очолюваної Ж. Гедом, КОМПу́т, у, ч., icm. Реєстр козацького війська періоду гетьманщини; мав значення правового акта; НАЛИВА́ЙКІВЩИНА, и, ж., icm. Повстання українських козаків проти польсько-шляхетського гніту наприкінці XVI ст. під проводом Северина Наливайка і т. ін.

Зафіксовано також нові абревіатури, хоча їх нараховується набагато меншє ніж у СУМ-11, наприклад: КДБ, КП(Б)У, НКВС, ОУН. Крім цього, історична термінологія зазнала змін через переосмислення понять, які раніше тлумачилися згідно з тодішньою ідеологією. У деяких статтях змінилася й кількість значень (див. табл. 18.1). Частина слів поповнила склад історичної термінолексики вже в пострадянські роки. 


\begin{tabular}{|c|c|}
\hline СУМ-11 & СУМ-20 \\
\hline 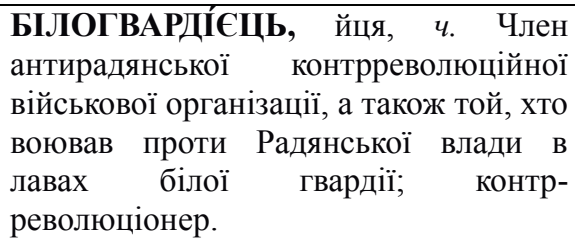 & $\begin{array}{l}\text { БІЛОГВАРДІ́ЄЦЬ, Ійця, ч., icm. Учасник } \\
\text { військових формувань, які під час } \\
\text { громадянської війни 1917-1922 рр. боролися } \\
\text { проти радянської влади, військ УНР, загонів } \\
\text { анархістів і т. ін. за відновлення колишньої } \\
\text { Російської імперії. }\end{array}$ \\
\hline 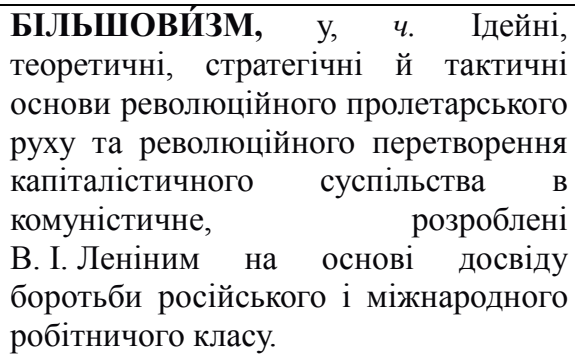 & $\begin{array}{l}\text { БІЛЬШОВИ́ЗМ, у, ч., icm. 1. Ідейна течія і } \\
\text { політичний рух радикальних марксистів на } \\
\text { початку ХХ ст. у Російській імперії, які мали } \\
\text { на меті захоплення влади і встановлення } \\
\text { диктатури пролетаріату, а в подальшому - } \\
\text { будівництво соціалізму і комунізму. }\end{array}$ \\
\hline $\begin{array}{l}\text { БОГОБУДІВНИ́ЦТВО, а, } c . \text { Ворожа } \\
\text { марксизмові реакційна релігійно- } \\
\text { філософська течія, що виникла в Росії } \\
\text { після поразки революції 1905-1907 } \\
\text { pp. у середовищі ідейно нестійкої } \\
\text { соціал-демократичної інтелігенції. }\end{array}$ & $\begin{array}{l}\text { БОГОБУДІВНЙЦТВО, a, c., icm. Філо- } \\
\text { софсько-етична течія у середовищі російської } \\
\text { соціал-демократії на початку ХХ ст. }\end{array}$ \\
\hline $\begin{array}{l}\text { ДИРЕКТО́РІЯ }{ }^{1}, \ddot{1}, ж \text { ж, iст. (з великої } \\
\text { літери). 1. Уряд Французької } \\
\text { республіки (1795-1799). } \\
\text { 2. Тимчасовий уряд України (1918- } \\
\text { 1920). }\end{array}$ & $\begin{array}{l}\text { ДИРЕКТӦРІЯ, }, \text { ж., icm. } \\
\text { Назва деяких урядів, наприклад у Франції в } \\
\text { епоху буржуазної революції (1795-1799 рр.), } \\
\text { контрреволюційного уряду на Україні (1918- } \\
1919 \text { рр.). }\end{array}$ \\
\hline
\end{tabular}

Основу термінології з анатомії в 11-томному словнику становить переважно іменникова лексика на позначення органів і систем людського організму, а також значна частина прикметників, утворених від відповідних іменників. Наприклад, альвеоли - альвеолярний, вена - венозний, епітелій - епітеліальний, кришталик кришталиковий, куприк - куприковий, моляри - молярний, носоглотка носоглотковий, очеревина - очеревинний тощо.

Дієслівна лексика цієї галузі практично відсутня, за винятком таких слів, як ЗЧЛЕНО́ВУВАТИ, Ую, Уєш, недок., ЗЧЛЕНУВА́ТИ, у́ю, У́єш, док., щุо. ... 3. анат. Бути засобом рухомого або напіврухомого з'єднання (кісток, хрящів і т. ін.) в організмі людини або тварини та ЗЧЛЕНО́ВУВАТИСЯ, ується, недок., 
ЗЧЛЕНУВА́ТИСЯ, у́ється, док. ... 3. анат. Сполучатися рухомим або напіврухомим 3'єднанням (про кістки, хрящі і т. ін.) в організмі людини або тварини.

У термінологічній лексиці з анатомії можна виокремити дев'ять тематичних груп:

1. Назви органів дихання: альвеоли, носоглотка, плевра.

2. Назви сечостатевих органів: матка, яєчник, уретра.

3. Найменування частин скелету людини: фаланга, тім'ячко, крижі.

4. Назви органів чуття: ірис, кришталик, ковадло, колбочка.

5. Назви органів травлення: апендикс, кишка, пілорус.

6. Назви частин нервової системи: блукаючий нерв, ворота, дендрит.

7. Найменування частин серцево-судинної системи: вена, передсердя.

8. Назви м'язів: згинач, сухожилля, розгинач.

9. Назви тканин: епітелій, оболонка, сумка.

Термінологія з анатомії в СУМ-20 порівняно із СУМ-11 представлена значно менше, іiі кількість збільшилася менше ніж наполовину. Розширили реєстр переважно одиниці, що ввійшли до групи слів на позначення:

1) м'язів та їхніх складників (це найчисленніша за кількістю доданих термінів група): (АБду́кТОР, а, ч., анат. М'яз, який здійснює відведення кінцівки або іiї частини (наприклад, руки, ноги, пальця); відвідний м'яз; ЕКСТЕ́НЗОР, а, ч., анат. М'яз, який здійснює розгинання якої-небудь частини тіла; розгинач; МІОБЛА́СТИ, ів, мн. (одн. міобла́ст, а, ч.), анат. Молоді м'язові клітини в людини і тварин; СИНЕРГІ́СТИ, ів, мн., анат. М'язи або група м'язів, які діють спільно в одному й тому напрямі стосовно іншого м’яза; ТРИ́ЦЕПС, а, ч., анат. Триголовий м'яз та ін.);

2) нервової системи (АКСо́Н, а, ч., анат. Відросток нервової клітини, що проводить імпульс від тіла клітини до інших нервових клітин та органів; НЕВРИ́Н, у, ч., анат. Оболонка нервового стовбура; НЕЙРОФІБРИ́ЛИ, и́л, мн., aнат. Протоплазматичні ниткоподібні утвори в нервових клітинах i їхніх відростках). 
Крім того, у СУМ-20 з'явилися прикметники, утворені на основі відповідних іменників, що були зафіксовані в СУМ-11. Причому частина з них має варіантне написання. Наприклад: аортний i аортальний, артерійний (в одинадцятитомному Словнику - артеріальний), колагеновий.

Близько половини лінгвістичної термінології в СУМ-11 становить іменникова лексика на позначення процесів, явищ, об’єктів різних підрозділів мовознавчої галузі знань. Це переважно слова іншомовного походження (консонант, монофтонг, палаталізація). У лінгвістичній терміносистемі спостерігається широке використання синонімії (синонімами є запозичені слова й українські відповідники), що найбільше виявляється у фонетиці. Наприклад: асиміляція - уподібнення, дисиміляція - розподібнення, консонант - приголосний, палаталізація - пом'якшення тощо.

Досить поширена в аналізованому матеріалі прикметникова лексика (становить близько третини від усієї термінології цієї галузі). Велику частину прикметників подано як через описову статтю - переважно терміни, що стосуються характеристики звуків (ЗАЗУ́БНИЙ, a, е, лінгв. Який утворюється при зближенні кінчика язика з верхніми передніми зубами; ФРИКАТЙВНИЙ, a, е, лінгв. Який утворюється тертям видихуваного повітря в щілині між зближеними органами мовлення (про звук); щілинний; ЯЗйЧНИй, a, e, лінгв. Який утворюється за участю язика), так і відсилкову (через відповідний іменник) (АКЦЕ́НТНИЙ, а, е, лінгв. Прикм. до акце́нт 2; АФІкСА́ЛЬНИй, а, е, лінгв. Стос. до афікса; ВИГУКО́ВЙ̆, а, е, лінгв. Прикм. до ви́гук 2).

Характерною особливістю нечисленної дієслівної лексики є те, що майже вся вона належить до фонетики (артикулювати, елідувати, лабіалізувати, м'якиити, назалізувати, палаталізувати, палаталізуватися, уподібнюватися тощо).

Загалом термінологію з лінгвістики можна поділити на тематичні групи за їі розділами:

1. Поняття словотвору: абревіація, афіксація, редуплікаџія, суплетивізм.

2. Поняття морфології: адвербіалізащзія, вигук, субстантивація, час.

3. Поняття лексикології: англіцуизм, антоніми, калька. 
4. Поняття фонетики: асиміляція, африкат, голосний, звук, палатальність.

5. Поняття морфеміки: афікс, інфікс, морфема.

6. Поняття синтаксису: звертання, період, синтагма.

7. Поняття діалектології: говірка, ізоглоса, наріччя.

8. Поняття лексикографії: глосарій, реєстр, ремарка.

Лінгвістична терміносистема поповнилася великою кількістю іншомовних слів, зокрема й синонімічними до вже зафіксованих понять. Як показало дослідження, лінгвістичних одиниць у СУМ-20 додано більше ніж удвічі. Багато нових термінів поповнили такі розділи мовознавства:

1) морфологію (АД'ЄКТИ́в, а, ч., лінгв. Клас слів, які мають лексикограматичні ознаки прикметника (а також похідні слова - ад'єктивний, ад'єктивований, ад'єктивуватися); АКУЗАТи́в, а, ч., лінгв. Знахідний відмінок; ВОКАТИ́В, а, ч., лінгв. Кличний відмінок; ГЕРУ́НДІЙ, я, ч., лінгв. Іменна форма дієслова в латинській та деяких інших мовах; ІTЕРАТИ́В, а, ч., лінгв. Граматична категорія дієслова, що означає багаторазову або повторювану дію);

2) синтаксис (АППОЗИТИ́В, у, ч., лінгв. Те саме, що при́кладка 2; АППОзи́цІя, ї, ж. 2. лінгв. Те саме, що аппозити́в; ГІПОТА́КСИС, у, ч., лінгв. Підрядний зв’язок між реченнями; СИНТАКСЕ́МА, и, ж., лінгв. Мінімальна семантико-синтаксична одиниця, компонент семантичної структури речення);

3) фонетику (АБРУПТИ́В, а, ч., лінгв. Проривний приголосний звук, під час вимовляння якого разом із зімкненням у роті утворюється друге зімкнення гортані між зв'язками; АЛОФо́Н, а, ч., лінгв. Варіант фонеми, що залежить від сусідніх звуків; ВІБРА́НТ, а, ч., лінгв. Дрижачий приголосний звук; ІМПЛО́зІя, ̈̈, ж., лінгв. Перша фаза артикуляції змичного приголосного - змикання);

4) лексикологію (АВТОЛО́ГІя, ї, ж., лінгв. Уживання слова в прямому значенні; АГНО́НІМ, а, ч., лінгв. Маловідоме слово, незнайоме більшості носіїв мови; БІБЛЕЇЗМ, У, ч. 1.лінгв. Біблійне слово або вираз, які ввійшли в загальнонародну мову; БОЛГАРИ́ЗМ, у, ч., лінгв. Слово, вираз, запозичені 3 болгарської мови; ЕНАНТІОСЕМі́я, ї, ж., лінгв. Поєднання протилежних значень в одному слові та ін.). 
У реєстрі СУМ-20 зафіксовано також лексику на позначення двомовності індивідів. Це такі терміни: БІЛІ́НГВ, а, ч., лінгв. Той, хто володіє двома мовами; БІЛІНГВА́ЛЬНИЙ, а, е, лінгв. Те саме, що двомо́вний; БІЛІНГВі́ЗМ, у, ч., лінгв. Двомовність; уживання двох мов у межах певної соціальної спільноти, передусім держави.

Широкий спектр семантичних досліджень, а також їх взаємодію з іншими підрозділами лінгвістики відбивають складні терміни 3 першою частиною семантико-: семантико-граматичний, семантико-морфологічний, семантикосинтаксичний, семантико-стилістичний, семантико-фонетичний, семантикофразеологічний.

Додано чимало термінів із різних підрозділів ономастики, зокрема й на позначення назв самих підрозділів: ергонім, ергоніміка, ергонімія, зоонім, зооніміка, зоонімія, катойконім, мікротопонім, мікротопоніміка, мікротопонімія та ін.

У термінології з фізики (СУМ-11) нараховується велика кількість іменників, значна частина прикметників та порівняно небагато дієслів. Істотною особливістю цієї галузі є те, що вона містить у своєму складі чимало термінів на позначення спільних понять із такими науковими сферами, як хімія, техніка, математика. Відповідно ці слова мають дві ремарки. Наприклад: АБСОРБЕ́НТ, у, ч., фiз., xiм. Речовина, що має здатність вбирати, всмоктувати інші речовини; АНІО́Н, а, ч., piз., хім. Негативно заряджений іон, що осідає під час електролізу на аноді; IÓH, а, ч., фіз., хім. Електрично заряджена частинка, яка утворилася з атома внаслідок утрати або приєднання електронів; АТМОСФЕ́РА, и, ж. ... 4. фіз., техн. Одиниця вимірювання тиску, яка дорівнює тискові ртутного стовпа заввишки 760 мм, або

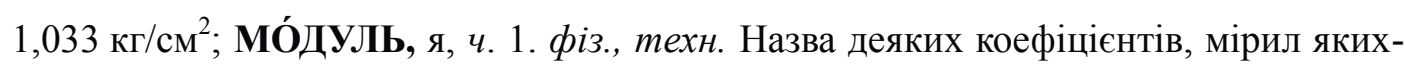
небудь величин; СИ́МвоЛ, у, ч. ... 3. мат., фіз. Умовне позначення якої-небудь величини, поняття, запроваджене певною наукою; СКАЛЯ́Р, а, ч., мат., фiз. Величина, яка, на відміну від вектора, повністю визначається числовим значенням (дійсним числом), без вказівки на напрям; ЦЕНТР, ч. 1.род. а, мат., фiз. Точка перетину уявних осей, ліній у фігурі, точка зосередження якихось відношень у тілі. 
Фізична термінологія в досліджуваному матеріалі нараховує велику кількість іменників на позначення процесів, явищ, одиниць вимірювання. Значна частина термінів у Словнику - слова іншомовного походження, які є переважно однозначними (абсорбц̧ія, ампераж, ареометр, реверберація, рефракція, електромагніт, електропровідність, парамагнетизм, фотострум тощо). Також досить поширені складні утворення 3 національними складниками (променезаломлення, самозбудження, світлозаломлювання, світлосила, теплотворення тощо).

Крім іменникової лексики, у СУМ-11 значну кількість термінологічних одиниць iз фізики становлять ад'єктиви. Переважна частина таких прикметників відіменникова (ІЗОТРО́ПНИЙ, a, е, фiз. Стос. до ізотропії; ІОНОСФЕ́РНИЙ, a, е, фіз. Прикм. до іоносфера) або входить до складу термінологічних словосполучень (Зо́внішні си́ли, - фіз. сили, що діють на тіло зовні, 3-за меж чого-небудь; Поступа́льний рух, - фіз. рух твердого тіла, при якому всі точки тіла рухаються паралельно одна одній, тобто описують однакові траєкторії і в кожний момент часу мають однакову швидкість і прискорення; Фо́кусна ві́ддаль віддаль від фокуса оптичної системи до вершини її заломлюючої або відбивної поверхні, тобто поверхні лінзи або дзеркала). Прикметниковій лексиці цієї галузі властива також ще й варіативність (двовгнутий - двоввігнутий, двоопуклий двовипуклий, ємнісний-ємкісний, надзвуковий-понадзвуковий тощо).

Загалом у термінології з фізики, зафіксованій у Словнику української мови в 11-ти томах, можна виділити вісім груп:

1. Найменування на позначення пристроїв, приладів: ареометр, деклінатор, евдіометр, електрометр.

2. Назви величин: густина, електроємність, маса, скаляр.

3. Назви одиниць вимірювання: ангстрем, кюрі, максвел, стен.

4. Назви на позначення процесів та явищ: дифракц̧ія, іррадіація, триболюмінесиенція, фотоелектрика, іонізація.

5. Назви на позначення властивостей: зчепність, парамагнетизм, хроматизм.

6. Найменування на позначення атомних i субатомних частинок: альфачастинки, електрон, нейтрон. 
7. Назви галузей, розділів фізики: радіофізика, термодинаміка.

8. Найменування на позначення методів дослідження: динамометрія, електрометрія, калориметрія.

Термінологія з фізики порівняно із СУМ-11 збільшилася більше ніж у два рази. Найбільше новими поняттями в СУМ-20 поповнилися такі тематичні групи:

1) назви приладів, пристроїв (ВЕБЕРМЕ́ТР, а, ч. Прилад для вимірювання магнітного потоку; МАС-СПЕКТРО́МЕТР, а, ч. Прилад для поділу іонізованих атомів або молекул за їхніми масами; ТЕЛЕАМПЕРМЕ́ТР, а, ч., фіз. Прилад для вимірювання сили електричного струму на відстані);

2) назви речовин (АНТИРЕЧОВИНА́, и́, ж., фіз. Матерія, утворена 3 античастинок; ДІАМАГНЕ́ТИК, а, ч., фіз. Речовина, якій властива негативна магнітна сприйнятливість; МЕТАМАГНЕ́ТИК, у, ч., фіз. Магнітна речовина, якій власт. метамагнетизм);

3) назви одиниць вимірювання (ВЕ́БЕР, а, ч., фiз. Одиниця виміру магнітного потоку в Міжнародній системі одиниць СІ; ГАЛ ${ }^{2}$, а, ч., фіз. Одиниця прискорення, названа на честь Галілео Галілея; ГА́УС, а, род. мн. гаусів $i$ гаус, ч., фiз. Одиниця магнітної індукції; ГЕКТОВА́т, а, ч., фіз. Одиниця потужності, що дорівнює 100 ватам; ЕРСТЕ́Д, а, ч., фіз. Одиниця напруженості магнітного поля, що дорівнює 79,58 ампера на метр);

4) назви процесів та явищ (БЛО́КІНГ-ПРОЦЕ́С, у, ч., фiз. Лавиноподібний процес зміни значень сили струму та напруги, який спричиняє відкриття або закриття транзистора; МАГНЕТИЗА́ЦІЯ, ї, ж. 1. фіз. Процес набування магнетизму (у 1 знач.); МЕТАМАГНЕТИ́ЗМ, у, ч., фiз. Явище переходу металу, що перебуває в парамагнітному стані, у феромагнітний стан під дією магнітного поля);

5) найменування величин (МАГНІТУ́ДА, и, ж., фіз. Умовна величина, що характеризує загальну енергію пружних коливань, спричинених землетрусами або вибухами; ПСЕВДОСКАЛя́р, а, ч., мат., фiз. Величина, яка, на відміну від вектора, повністю визначається числовим значенням (дійсним числом), без вказівки на напрям; ЯСКРА́вІСТЬ², вості, ж., фiз. Фізична величина, яка 
характеризує інтегральну інтенсивність світіння у видимому діапазоні довжини хвиль, у розрахунку на одиницю площі випромінювача);

6) назви методів дослідження (ВАКУУММЕ́ТРІЯ, ї, ж., фіз. Сукупність методів вимірювання тиску розріджених газів; ВОЛЬТАМПЕРОМЕ́ТРІЯ, $і$,. фiз. Сукупність електрохімічних методів дослідження та аналізу залежності сили струму від потенціалу індикаторного мікроелектрода, зануреного в електролітичний розчин; МАС-СПЕКТРОГРА́ФІЯ, ї, ж., фіз. Метод визначення хімічного, фазового складу і молекулярної структури речовини, що базується на реєстрації спектра мас іонів, утворених унаслідок іонізації атомів і (або) молекул проби; ДИЛАТОМЕ́ТРІЯ, ї, ж., фіз. Метод дослідження речовин, що грунтується на вимірюванні розмірів фізичних тіл під дією зовнішніх чинників: температури, тиску, електричного й магнітного полів, іонізувальних випромінювань і т. ін.).

У СУМ-20 з'явилося багато складних термінів, що пишуться через дефіс (у СУМ-11 таких слів зафіксовано не було): бета-частинки, блокінг-процес, гамма-випромінювання, дельта-електрони, мас-спектрометр тощо.

У медичній галузі поширені прикметники, дієслова, хоча основу іiі становлять іменники. Більша частина іменникових термінів СУМ-11 - це слова на позначення захворювань людського організму (аритмія, бронхіт, флебіт), методів лікування хворих (вітамінотерапія, хіміотерапія), лікувальних засобів (вакцина, сироватка), медичних приладів та інструментів (ендоскоп, стетограф). С також значна кількість термінів на позначення розділів медицини (нозологія, неврологія).

Серед терміноодиниць цієї галузі міститься велика частина прикметників, утворених від іменників та із самостійними значеннями, причому останні досить поширені. Наприклад: ЛЕТА́ЛЬНИй, а, е, мед. Який веде до смерті; смертельний; ЛЕТУ́чИЙ, а, е. ... // мед. Який раптово виникає то в одному, то в другому місці, швидко проходить в одному місці й з'являється в іншому (про хвороби); ПОВОРО́ТНИЙ, а, е. ... 4. мед. Який повторюється, відновлюється (про хворобу); ПРОДРОМА́ЛЬНИЙ, а, е, мед. Пов'язаний з початковою стадією розвитку хвороби, коли з'являється загальне нездужання, але характерні ознаки 
хвороби ще відсутні; РЕТИКУЛЯ́РНИЙ, a, e, мед. Який утворює кровотворні органи.

Дієслівна термінологія - це переважно одиниці на позначення дій лікаря, спрямованих на лікування або профілактику хвороби. Сюди належать такі терміни, як антисептувати, вакцинувати, вправляти, дренажувати, загіпсувати, катетеризувати, перещуеплювати, ревакцинувати, тампонувати, хлороформувати тощо.

У медичній термінології можна виділити сім тематичних груп:

1. Назви хвороб: авітаміноз, апендицит, аритмія, бронхіт, емфізема.

2. Назви методів лікування хворих: витягання, вітамінотерапія, санація, серотерапія.

3. Найменування фахівців медичної галузі: гідропат, невропатолог, рентгенокімограф.

4. Назви медичних інструментів, приладів: ендоскоп, катетер, niднімач, стетограф.

5. Назви лікувальних засобів: вакц̧ина, тубазид, свічка, сироватка.

6. Назви розділів медицини, учень: нозологія, невропатологія, неврологія, етіологія.

7. Назви методів обстеження хворих: ендоскопія, огляд, отоскопія, перкусія, рентгенокімографія.

Матеріал СУМ-20 засвідчує, що медична терміносистема $\epsilon$ основним джерелом поповнення його реєстру термінологією. Порівняно із СУМ-11 у СУМ20 кількість медичних термінів збільшилася в три рази, що свідчить про швидкий розвиток медичної галузі. До того ж активне використання термінів медицини (традиційної і нетрадиційної) в науково-популярній, публіцистичній літературі, рекламі, на форумах тощо вказує на їі вагому роль в житті пересічних громадян. Так, у двадцятитомному словнику, наприклад, з’явилися слова на позначення:

1) нових методів лікування (АВТОТРАНСФУ́3Ія, ї, ж., мед. Метод лікування переливанням хворому його власної крові; АЛЬГОТЕРАПі́Я, ї, ж., мед. Лікування за допомогою фармацевтичних засобів, виготовлених із водоростей; ВІБРОТЕРАПІ́я, ї, ж., мед. Метод лікування деяких захворювань за 
допомогою вібрації, створюваної спеціальними пристроями; ДЕЛЬФІНОТЕРАПІ́я, ї, ж., мед. Метод лікування, заснований на спілкуванні 3 дельфінами; ІПОТЕРАПі́я, ї, ж. Метод лікування, що грунтується на взаємодії людини зі спеціально навченим конем; КІНЕТОТЕРАПі́я, ї, ж., мед. Метод лікування фізичними вправами, масажем за допомогою спеціальних апаратів i приладів; механотерапія);

2) хвороб (АНОКСЕМі́я, ̈̈, ж., мед. Відсутність кисню в крові; АНОРЕКСІ́я, ї, ж. Захворювання, що характеризується втратою ваги, надмірним страхом повноти, викривленим уявленням про свій зовнішній вигляд і глибокими обмінними та гормональними порушеннями; ВІЛ-ІНФЕ́КЦІЯ, $\ddot{1}, ~ ж$. Захворювання, викликане вірусом імунодефіциту людини (ВІЛ); ГІПЕРПАРАТИРЕО́3, у, ч., вет., мед. Ендокринне захворювання, зумовлене надлишковим утворенням гормону щитоподібної залози; МІКОПЛАЗМО́3, у, ч., вет., мед. Гостре інфекційне захворювання, спричинене мікоплазмами). Особливістю цієї групи є те, що переважна частина захворювань поширена і в людей, і в тварин, тому вони належать не лише до царини медицини, а й ветеринарії. Подібні слова в СУМ-20 мають дві ремарки - вет., мед. (у СУМ-11 більшість таких одиниць зараховано лише до медичної галузі);

3) методів обстеження хворих (АНОМАЛОСКОПі́я, ї, ж., мед. Дослідження особливостей колірного зору за допомогою аномалоскопа; БРОНХОГРА́ФІЯ, ї, ж., мед. Метод рентгенологічного дослідження бронхів, що полягає у введенні в бронхи непроникної для рентгенівських променів речовини; ДУОДЕНОСКОПі́я, ї, ж. Метод дослідження дванадцятипалої кишки за допомогою спеціального ендоскопа; КАПІЛЯРОГРА́ФІЯ, ї, ж., сnеu. Метод дослідження кровоносних капілярів, а також графічне зображення його результатів; МАМОГРА́ФІЯ, ї, ж., мед. Діагностичний метод рентгенографічного дослідження жіночих молочних залоз);

4) медичних приладів, інструментів (АНГІО́ГРАФ, а, ч. Апарат для ангіографічних досліджень; ІНТУБА́ТОР, a, ч. Медичний інструмент для інтубації; КАПІЛЯРОСКО́П, а, ч. Медичний прилад, різновид мікроскопа, 
признач. для неінвазивного дослідження кровоносних капілярів; ЛАПАРОСКО́П, a, ч. Медичний прилад для огляду черевної порожнини; ендоскоп).

Варто зауважити, що найменування приладів та інструментів спочатку було ремарковано аналогічно до того, як це зроблено в СУМ-11. Тобто такі назви віднесено до тієї галузі, де їх найчастіше використовують. Однак у процесі подальшої роботи над СУМ-20 було прийнято рішення залишати ці найменування не маркованими, оскільки пристрої, прилади, інструменти, машини - це технічні винаходи, незалежно від того, де їх застосовують.

Словник поповнився також новими тематичними групами лексики, які відбивають розвиток нових напрямків медичних знань. Таким чином, у СУМ-20 додалося три нових групи:

1. Назви фобій: агорафобія, бацилофобія, вакцинофобія, венерофобія, зоофобія, клаустрофобія, ксенофобія, неофобія.

2. Найменування, пов'язані 3 патологічною схильністю до чого-небудь: геронтофілія, зоофілія, некрофілія, німфофілія, нозофілія.

3. Назви, що стосуються пластичної хірургії: абдомінопластика, блеропластика, мамопластика, мелопластика.

Сільськогосподарська термінологічна лексика (СУМ-11) поєднує у своєму складі велику частину іменників, що позначають способи обробітку землі, назви працівників сільського господарства, техніки, знаряддя праці тощо, значну кількість дієслів та небагато прикметників. Суттєва частина термінів-іменників $є$ віддієслівною. Наприклад: БУКЕТУВА́ННЯ, я, с., с. г. Дія за знач. букетувати; ВАЛКУВА́ННЯ, я, c., с. г. Дія за знач. валкувати; КАГАТУВА́ННЯ, я, с., с. г. Дія за знач. кагатувати та ін.

Особливістю цієї галузі є також наявність значної кількості термінівкомпозитів (багатолемішник, картоплекопач, купиноріз, кущоріз, люпиносіяння, пасовищезміна, породоутворення, посухостійкий, розсадосаджалка тощо).

Дієслівна лексика вживається в основному на позначення діяльності працівників сільського господарства (букетувати, валкувати, вершкувати, зяблювати, кагатувати, калібрувати, компостувати, лесувати, мульчувати, протруювати, фумігувати, илейфувати, шредерувати). 
Більшість прикметникової лексики (значну частину якої становлять складні слова) вживається $з$ описовими тлумаченнями: ЗАСУХОСТІЙКЙЙ, á, é, c. г. Здатний витримувати засуху (про рослини); ОРНОПРИДА́ТНИЙ, a, е, с. . Придатний для оранки; СТАРОПЕРЕЛО́ГОВИЙ, а, е, с. г. Який давно не піддавався обробіткові (про орні землі) тощо.

Загалом у сільськогосподарській термінології можна виділити сім тематичних груп:

1. Назви на позначення техніки, знарядь праці: багатолемішник, змійка, картоплекопач, кущьоріз, рало.

2. Назви приміщень: брудергауз, картоплесховище, оборіг.

3. Найменування працівників сільськогосподарської галузі: кагатник, протруювач, сакманник, шарувальниия, яровизатор.

4. Назви хвороб рослин і тварин: аскохітоз, зона, нозематоз.

5. Найменування, які стосуються розмноження тварин: окріл, охота, первістка, переярка.

6. Назви способів обробітку землі: заборонувати, залужувати, мульчувати.

7. Назви процесів, дій, що пов'язані з розведенням та утриманням тварин: злучати, осіменяти, піддоювати.

Сільськогосподарська термінологія в СУМ-11 становила одну з найбільших терміносистем. У Словнику української мови у 20-ти томах ця лексика розширилася трохи більше ніж на чверть. Поповнили його реєстровий склад переважно поняття на позначення сільськогосподарської техніки, знарядь праці (БУРТОНАКРИВА́Ч, á, ч., c. г. Машина або пристрій для накривання землею буртів бульбоплодів, буряків, силосу і т. ін.; ГРУНТОРОЗПУ́ШУВАЧ, а, ч. Навісна або причіпна сільськогосподарська машина для розпушування грунту; ЗЕРНОКОМБА́ЙН, a, ч. Комбайн, признач. для збирання зернових сільськогосподарських культур; КАРТОПЛЕКОМБА́ЙН, а, ч., с. г. Комбайн, пристосований для викопування картоплі);

3'явилася значна кількість прикметників із самостійними значеннями, серед яких є полісемічні, причому зафіксовано й внутрішньогалузеву багатозначність термінів (БЕЗВІДВА́ЛЬНИЙ, а, е, 1. Який здійснюється без обороту шару грунту 
плугами зі знятими відвалами. 2. Признач. для обробки грунту без обороту шару землі; БЕЗПОЛИЦЕ́ВИЙ, a, е, c. г. Який розпушує грунт без перевертання його шарів або горизонтів; КАРТОПЛЕЗБИРА́ЛЬНИЙ, а, е, с. г. Признач. для механізованого збирання врожаю картоплі; МОРОзОВИТРИВА́ЛИЙ, a, е, с. г. Який витримує температуру нижче нуля; морозостійкий).

Дещо меншими за кількістю тематичних груп у СУМ-11 $є$ такі терміносистеми, як біологія ( $\approx 2,13 \%$ від загальної кількості термінів), спорт $(\approx 1,73 \%)$, геологія $(\approx 2,37 \%)$, математика $(\approx 2,04 \%)$ (мають шість тематичних груп), економіка $(\approx 0,87 \%)$, музика $(\approx 2,46 \%)$, техніка $(\approx 5,9 \%)$ (нараховують п’ять тематичних груп).

Біологічна термінологія $є$ однією 3 найдавніших в українській мові. 3 початку свого зародження вона мала риси стихійно організованої системи, яка об'єднувала у своєму складі переважно назви рослин, тварин та явищ природи, відбивала процес пізнання всього живого. 3 розширенням знань про закономірності розвитку та властивості живих організмів народна термінологія стала передумовою формування досконалішої наукової термінології.

У СУМ-11 біологічна терміносистема не утворює великої кількості тематичних груп, оскільки в реєстрі Словника подано терміноодиниці окремих іiі підрозділів (зоології, ботаніки тощо), що вживаються з відповідними ремарками. Основою біологічної лексики є переважно поняття на позначення процесів, явищ (ізогамія, некробіоз), організмів (грибок, рикетсіі), речовин (сироватка, фермент).

Біологія має у своєму складі багато спільних понять із хімією та медициною. Наприклад: АТРОФІ́я, ї, ж. 1. біол., мед. Зменшення розмірів окремих органів або тканин організму, яке супроводиться занепадом їх життєдіяльності; БІЛО́к' ${ }^{1}$ лка́, ч. 2... біол., хім. Складна хімічна сполука, органічна речовина, яка $є$ основною складовою частиною клітин організмів; білковина. 
Ще однією характерною особливістю цієї галузі $є$ наявність великої кількості іншомовних термінів, полісемічних із поняттями лінгвістичної царини $^{159}$.

Щодо частиномовного співвідношення, то основу біологічної терміносистеми становить іменникова лексика (близько 80 \%). Прикметники й дієслова не є численними та не мають якихось особливих ознак.

У складі біологічної термінології виділяємо шість тематичних груп:

1. Назви організмів: аероби, збудник, сапроби, продуцент.

2. Назви на позначення процесів, явищ: аглютинація, адаптація, асиміляџія, дегенераиія, регенеращія.

3. Назви на позначення речовин та їхніх складників: аглютинін, білковина, хромоген.

4. Назви на позначення частин клітини: вакуолі, органоїди, фагощит, хромосома.

5. Назви на позначення об’єднань рослин і тварин: колонія, підклас, рiд, родина.

6. Назви розділів, напрямків біології: паразитологія, фенологія, фітобіологія, цитологія.

Порівняно зі Словником української мови в 11-ти томах біологічна терміносистема розширила свій склад більше ніж у три рази. Найбільше новими термінами поповнилися тематичні групи на позначення:

1) організмів (АВТОТРО́ФИ, ів, мн. (одн. автотро́ф, а, ч.), біол. Організми, які створюють необхідні для свого життя органічні речовини з неорганічних у процесі фотосинтезу або хемосинтезу; БАЗИФІ́ЛИ, ів, мн., біол. Організми, які добре розвиваються в лужних грунтах і водах; ГАЛОФІ́ЛИ, ів, мн. (одн. галофі́л, а, ч.), біол. Організми, пристосовані до життя в умовах підвищеної солоності; ЕВКАРІО́тИ, ів, мн. (одн. евкаріо́т, а, ч.), біол. Організми, клітини яких мають оформлене ядро, відділене від цитоплазми оболонкою);

${ }^{159}$ Приклади див. у монографії: Томіленко Л. М. Термінологічна лексика в сучасній тлумачній лексикографії української літературної мови. Івано-Франківськ: Фоліант. С. 54. 
2) речовин (АНГІОТЕНЗи́Н, у, ч., біол. Біологічно активна речовина пептид, що утворюється в крові людини і тварин, регулює артеріальний тиск та водно-сольовий обмін в організмі; АНТИГОРМО́Н, а, ч., біол. Захисна речовина, що іiі виробляє організм при тривалому введенні в нього великої кількості білкових гормональних препаратів; ГІАЛІ́̈, у, ч., біол. Напівпрозора щільна однорідна білкова речовина, що з'являється в тканинах організму при деяких патологічних процесах; ЛІЗОЛЕЦИТИ́Н, у, ч., біол. Органічна речовина, що утворюється внаслідок відщеплення від лецитину ненасиченої жирної кислоти);

3) процесів та Явищ (БІОЛЮМІНЕСЦЕ́НЦІЯ, ї, ж., біол. Видиме світіння організмів, пов'язане з процесами їхньої життєдіяльності; ГАМЕТОГЕНЕ́3, у, ч., біол. Процес розвитку й формування гамет; ГАСТРУЛя́цІя, ї, ж., біол. Процес розвитку двошарового зародка - гаструли 3 одношарового - бластули; ГОМЕОРЕ́3, у, ч., біол. Процес реалізації генетичної програми будови, розвитку й функціонування організму; ЗИГОТОГЕНЕ́3, у, ч., біол. Процес утворення зиготи; МАКРОЕВОЛЮ́ЦІя, ї, ж., біол. Процес еволюції організмів на надвидовому рівні);

4) розділів і напрямків біології (БІОРИТМОЛо́ГІя, ї, ж. Розділ біології, що вивчає біоритми живої матерії; ГЕОБІОЛо́ГІя, ї, ж. Розділ біології, що вивчає сукупність усіх живих організмів і зв'язки між ними; ІМУНОБІОЛо́ГІЯ, ї, ж. Розділ біології, що вивчає загальнобіологічні основи імунітету, його походження, еволюцію; КАРІОЛо́ГІя, ї, ж., біол. Розділ цитології, що вивчає виникнення, будову, зміни і функції клітинного ядра та його компонентів).

Характерною особливістю біологічної терміносистеми $є$ широке вживання слів у множині (у СУМ-11 подібних назв зафіксовано менше) для позначення організмів (автотрофи, аероби, аеробіонти, анаероби, галофіли, геліобіонти, гігрофоби, еврибіонти, ендопаразити, еукаріоти, консументи, мікобактерії тощо), речовин (автомутагени, біогени, біополімери, глікозиди тощо).

Біологічна термінологія поповнилася також однією новою тематичною групою - назви методів дослідження: біоексперимент, біоіндикація, вірусоскопія.

Основою спортивної термінології в СУМ-11 $є$ іменникова лексика (переважно терміни на позначення різних видів спорту). Вона становить майже 
сімдесят відсотків від усіх слів, решта - дієслова та прикметники, яких приблизно однакова кількість у цій терміносистемі.

Як і лінгвістика, спортивна сфера функціонування лексики відзначається великою кількістю запозичень. Це насамперед назви видів спорту (бокс, лаунтеніс, стипль-чез), поняття, що стосуються спортивних змагань (гейм, нокаут, сnурm, фінт), назви осіб, які беруть участь у спортивних змаганнях (командор, рефері, хавбек) тощо.

Прикметникова й дієслівна лексика, зафіксована СУМ-11, не поширена в цій галузі. Дієслова вживаються переважно на позначення певних дій, прийомів, що виконують спортсмени (вижимати, контратакувати, нокаутувати, спуртувати, табанити, траверсувати). Значна частина ад'єктивів $є$ компонентом термінологічних словосполучень (водне поло, гігантські кроки, фігурне ковзання (катання), фінськийхід).

Спортивну лексику можна поєднати у шість тематичних груп:

1. Назви на позначення способів плавання: батерфляй, брас, сажень.

2. Назви спортивного знаряддя: козел, штанга, ядро.

3. Найменування на позначення спортивних вправ: вис, ипагат, біга (біги), гіт, проскачка, бокс, жим, поштовх.

4. Назви елементів спортивної боротьби: нокаут, нокдаун, форсинг.

5. Назви, що вживаються в спортивних командних іграх: nac, подача, чвертьфінал.

6. Найменування спортсменів - представників різних видів спорту: ватерполіст, гирьовик, півзахисник, хокеїст.

Спортивна термінологія (збільшилася майже вдвічі) розширила свої межі в реєстрі СУМ-20 за рахунок нових слів на позначення понять, що стосуються боксу (АПЕРКО́Т, у, ч., спорт. У боксі - удар знизу вгору в підборіддя або в корпус суперника; БЛОКА́ж, у, ч. Один із способів захисту в боксі; ДжЕБ, а, ч., сnорm. У боксі - прямий удар витягнутою рукою; ІНФА́ЙТИНГ, у, ч., спорт. У боксі бій на близькій дистанції).

Крім того, з'явилося багато номінацій на позначення спортсменів (АВТОПЕРЕГО́ННИК, а, ч. Спортсмен, який бере участь в автоперегонах; 
БАТУТИ́СТ, a, ч. Спортсмен, що займається стрибками на батуті; ВЕЛОПЕРЕГО́ННИК, а, ч. Спортсмен, який бере участь у велоперегонах; МОтОБОЛі́ст, а, ч. Спортсмен, що грає в мотобол та ін.), спортивних змагань (АВТОМАРАФО́Н, у, ч., спорm. Перегони на автомобілях або мотоциклах із подоланням великих відстаней, АВТОРА́ЛІ, невідм., с. Спортивне змагання (перев. багатоденне) на автомобілях за визначеним режимом руху, БЛІЦТУРНÍP, у, ч. Вид спортивного змагання (перев. у шахи, шашки) за максимально короткий час, ВЕЛОМАРАФО́Н, у, ч. Спортивне змагання з велосипедної їзди на велику дистанцію (100-1000 кілометрів) або на час (6-24 години або більше)).

Поповнилася новими лексемами також тематична група на позначення понять, що стосуються спортивних ігор (НАВі́C ${ }^{2}$, а, ч., сnорm. У футболі, волейболі - передача м'яча іншому гравцеві, при якій м'яч описує в повітрі дугу; МАТЧБО́Л, у, ч. Розіграш м’яча в спортивній грі, результатом якого є перемога в матчі команди або гравця, що виграє за очками).

3’явилася й лексика на позначення видів спорту: авіаспорт, вейкобординг, кайтсерфінг, маунтинборд тощо.

Основу геологічної термінології в СУМ-11 становить іменникова й прикметникова лексика, яка позначає в основному реалії, явища, що пов’язані із життям, різноманітними процесами і т. ін., що відбуваються на Земній планеті. Натомість серед дієслів нараховується лише декілька одиниць цієї галузі.

Переважну частину терміносистеми становить лексика іншомовного походження, більшість із якої однозначна, хоча $є$ й багатозначна, що, як правило, належить й до інших галузей знань. Наприклад: СУФО́зІя, ї, ж., геол. Підмив шарів гірської породи і винос з них розчинних речовин і дрібних мінеральних частинок потоком грунтових вод; КОРО́зІя, ї, ж. 1. хім. Руйнування поверхні металів унаслідок їх хімічної взаємодії з зовнішнім середовищем; іржавіння. 2. геол. Руйнування гірських порід під впливом повітря та води.

Прикметники-терміни геологічної царини переважно відіменникові: КРА́ТЕРНИЙ, а, е, геол. Прикм. до кратер; СИНКЛІНА́ЛЬНИЙ, a, е, геол. Стос. до синкліналі; ТРАНСГРЕСЙВНИЙ, а, е, геол. Пов'язаний із трансгресією.

Загалом у геологічній термінології нараховується шість тематичних груп: 
1. Назви часових періодів розвитку Землі: епоха, ера, юра.

2. Назви гірських порід: антикліналь, басейн, елювій, конгломерат.

3. Назви на позначення процесів, явищ: абразія, денудація, дислокація, ерозія.

4. Назви на позначення будови Землі: барисфера, останець, платформа, плита, ядро.

5. Найменування, пов'язані з водним простором: меандр, сель, терми.

6. Назви на позначення вчень та наукових напрямків геології: геотектоніка, мінералогія, стратиграфія.

Термінологія з геології в СУМ-20 зросла кількісно більше ніж утричі. Поповнилася ця терміносистема найбільше найменуваннями, що стосуються гірських порід (АГАЛЬМАТОЛі́т, у, ч. Щільна і м'яка дрібнозерниста гірська порода, яку використовують для різних декоративних виробів, а також у виробництві вогнетривів; БІОЛІ́ТИ, ів, мн. (одн. біолі́т, у, ч.). Гірські породи та мінерали, що утворилися внаслідок життєдіяльності тварин і рослин (наприклад, крейда, вапняк); органогенні породи; ВІДТО́РЖЕНЕЦЬ, нця, ч., геол. Уламок чи невеликий масив гірської породи, відділений внаслідок тектонічної діяльності або віднесений льодовиком на певну відстань; КІМБЕРЛі́т, у, ч. Вивержена магматична гірська порода чорного кольору з синім або зеленим відтінком).

Також з'явилася значна кількість термінів на позначення часових періодів розвитку Землі (АНТРОПОГЕ́Н, у, ч. Сучасний період геологічної історії Землі, останній період кайнозою, який триває близько 700 тисяч - 1 мільйон років; APXÉЙ, ю, ч. Найдавніша ера в геологічній історії Землі; ЕПІПАЛЕОЛÍТ, у, ч., геол. Перехідний період від епохи палеоліту до неоліту), найменувань, що стосуються будови Землі (АСТЕНОСФЕ́РА, и, ж., геол. Шар пониженої твердості, міцності та в'язкості у верхній мантії Землі; ГЕОСИНКЛІНА́ЛЬ, i, ж., геол. Витягнута в довжину велика ділянка земної кори, що характеризується інтенсивністю тектонічних процесів, високим ступенем деформації гірських порід; ГЕОСФЕ́РА, и, ж., геол. Кожна $з$ оболонок Землі з притаманними їм фізичними властивостями й хімічним складом; ГОРСТ, у, ч. Підвищена ділянка земної кори, обмежена ділянками, опущеними вздовж ліній скидів; МАÁP, у, ч., 
геол. Лійкоподібне або циліндричне заглиблення в земній корі, що має вулканічне походження), а також процесів та явищ (ГРАНІТИЗА́цІя, ї, ж., геол. Процес перетворення різних твердих гірських порід на породи, тотожні граніту або близькі до нього за складом і структурою; ЕПЕЙРОГЕНЕ́З, у, ч., геол. Явище повільних вікових нерівномірних підняттів і опускань земної кори, що не викликають складок у їі структурі; КАОЛІНІзА́цІЯ, ї, ж., геол. Процес зміни гірських порід із утворенням каоліну за рахунок перетворення мінералів, що містять глинозем та ін.).

Крім того, збільшилася кількість термінів на позначення вчень та наукових напрямків геології (ГЕОКРІОЛО́ГІЯ, ї, ж., геол. Наука про мерзлі гірські породи, грунти, їх походження та процеси і явища, пов'язані з їхнім промерзанням і таненням; мерзлотознавство; ГЕОХРОНОЛО́ГІя, ї, ж. Учення про хронологічну послідовність формування і вік гірських порід земної кори; МОБІЛі́ЗМ, у, ч., геол. Наукова теорія про горизонтальне переміщення частин земної кори).

Математична термінологія СУМ-11 містить у своєму складі більше половини іменників, значну частину прикметників і невелику кількість дієслів.

Іменникові одиниці слугують для найменування величин, чисел, функцій тощо. Цікаву особливість має лексика на позначення певних геометричних фігур. Складні слова демонструють синонімію такого типу, коли друга частина складного слова залишається незмінною, а перша виступає в одному випадку як власне українська форма, в іншому - як запозичення 3 російської мови (багатогранник-многогранник, багатокутник-многокутник). Хоча деякі слова подано тільки з першою частиною много- (многократність, многочленний).

Серед зафіксованих термінів-прикметників міститься чимало одиниць із описовими тлумаченнями: ВІД'СМНИЙ, а, е. ... 2. мат. Який є величиною, взятою із знаком мінус; менший від нуля; РІВНОБЕ́ДРЕНИЙ, а, е, мат.. Який має рівні бокові сторони (про геометричну фігуру); РІВНОСТОРО́ННІЙ, я, є, мат. Який має рівні сторони (про геометричні фігури); ЧОТИРИЗНА́ЧНИЙ, a, е, мат. Який складається з чотирьох знаків. 
Дієслова вживаються переважно на позначення певних математичних дій, розв'язування завдань тощо (додавати, інтегрувати, логарифмувати, описувати, скорочувати).

У складі термінології з математики можна виокремити шість тематичних груп:

1. Назви геометричних фігур, тіл: пентагон, трапеція, циліндр.

2. Назви геометричних ліній: відрізок, гіпербола, нормаль, синусоїда.

3. Назви величин: аргумент, величина, вимір, кривина.

4. Назви математичних (тригонометричних) функцій: косинус, котангенс, синус, тангенс.

5. Назви чисел: від'ємник, дріб, знаменник, модуль.

6. Назви розділів математики: алгебра, арифметика, комбінаторика, номографія.

Термінологія 3 математики розширила свій склад приблизно на вісімдесят відсотків і найбільше поповнилася словами на позначення:

1) геометричних ліній (АСИМПТО́ТА, и, ж., мат. Пряма, яка не має жодної спільної точки з певною кривою, що необмежено наближається до неї; АСТРО́їДА, и, ж., мат. Плоска крива у вигляді чотирикутної зірки; ГОДО́ГРАФ, а, ч., мат. Крива - геометричне місце кінців змінного за часом вектора, значення якого в різні моменти часу відкладені від спільного початку; ІНДИКАТРИ́СА, и, ж., мат. Крива, яка унаочнює уявлення про зміни векторів у просторі або на площині);

2) математичних функцій (КОВАРІÁHT, а, ч., мат. Функція коефіцієнтів і змінних певної форми, яка при лінійному перетворенні стає функцією коефіцієнтів і змінних перетвореної форми; МАЖОРА́НТА, и, ж., мат. Функція, значення якої не менше за відповідні значення певної функції; МІНОРА́НТА, и, ж., мат. Функція, значення якої не більше за відповідні значення іншої функції);

3) геометричних фігур, тіл - в основному як запозичених синонімів до українських відповідників (ГЕКСАГО́Н, а, ч., мат. Те саме, що шестику́тник; ГЕКСА́ЕДР, а, ч., мат. Багатогранник із шістьма гранями (напр., куб, п’ятикутна піраміда); ІКОСА́ЕДР, а, ч., мат. Те саме, що двадцятигранник); 
4) математичних дій (АЛГЕБРИЗУВА́ТИ, АЛГЕБРАЇЗУВА́ТИ, у́ю, у́єш, недок. $i$ док., щзо, мат. Зводити до алгебричного (алгебраїчного) вигляду; АПРОКСИМУВА́ТИ, у́ю, у́єш, недок. $i$ док., щ̧о, мат. Здійснювати апроксимацію; ІНТЕРПОЛЮВА́ТИ, ю́ю, ю́єш, недок. $i$ док., що, мат. Здійснювати інтерполяцію і т. ін.).

У цій терміносистемі з'явилася значна кількість відіменникових прикметників на позначення властивостей, функцій, форми тощо чого-небудь (аплікативний, апроксимаційний, асимптотичний, біноміальний, бінормальний, гексагональний, гелікоїдальний, гомеоморфний тощо). У реєстрі СУМ-20 зафіксовано й ад'єктиви із самостійним значенням (подібним до відіменникових), що $є$ твірними для деяких субстантивів (бієктивний - бієктивність, ізогональний - ізогональність, конформний - конформність тощо).

Половину економічних термінів в реєстрі СУМ-11 становлять іменники, більшу частину другої половини слів утворюють дієслова (зокрема й дієприкметники) та невелика кількість прикметників. Варто зазначити, що економічна царина - одна з не багатьох, у складі якої налічується чимало дієслів.

Іменникова лексика - це переважно абстрактні терміни на позначення понять, що пов’язані з виробничим процесом і купівлею-продажем товарів. Серед іменникових термінів значна частина віддієслівних (інвестування, картелювання, перевироблення, санірування, тезаврування, трестування).

Особливістю дієслів-термінів є те, що майже всі вони є двовидовими (ІНВЕСТУВА́ТИ, у́ю, у́єш, недок. $i$ док., перех., ек. Вкладати капітал у підприємство для одержання прибутків; КАРТЕЛЮВА́ТИ, ю́ю, ю́єш, недок. $i$ док., перех., ек. Об’єднувати окремі промислові капіталістичні підприємства в картелі; ПАРЦЕЛЮВА́ТИ, ю́ю, ю́єш, недок. $і$ док., перех., ек. Ділити на парцели (звичайно про землю); ТРЕСТУВА́ТИ, у́ю, у́єш, недок. $і$ док., перех. і неперех., ек. Об'єднувати в трест, у трести; включати в трест).

Ад'єктивна лексика цієї галузі утворена переважно від субстантивів (АМОРТИЗАцІ́йнИй, а, е. 1. ек. Стос. до амортизації (в 1 знач.); ІНВЕСТИЦі́ЙНИЙ, a, е, ек. Стос. до інвестиції; КАРТЕ́ЛЬНИЙ, а, е, ек. Прикм. до карте́ль ${ }^{1}$ ). 
Згідно 3 матеріалами дослідження, основну частину економічної термінології становлять запозичені одиниці, однак під час творення складних термінів досить активними є власне українські компоненти (багатоукладний, вантажопотік, дрібнотоварний, паєнагромадження, платоспроможний, продуктообмін).

У складі економічної терміносфери зафіксовано порівняно невелику частину термінів на позначення понять, що стосувалися не лише радянської, але й світової економіки, причому щодо других у тлумаченнях наголошено, що така реалія властива капіталізму, капіталістичним відносинам. Наприклад: КАРТЕ́ль , ю, ч., ек. Одна з форм капіталістичної монополії, учасники якої для підвищення прибутку укладають угоду про поділ ринків збуту, розміри виробництва, рівень цін на продукцію тощо; характеризується збереженням комерційної та виробничої самостійності об’єднаних підприємств; НАДПРИБУ́ТОК, тку, ч., ек. Прибуток, що значно перевершує середню норму прибутку в капіталістичному суспільстві; САНА́ЦІЯ, ї, ж. ... 2. ек. Система заходів, здійснюваних у капіталістичних країнах державою, щоб запобігти банкрутству банків, трестів і т. ін.

Загалом усю термінологію економічної галузі можна об'єднати в п’ять тематичних груп:

1. Найменування понять, що стосуються купівлі-продажу товарів: демпінг, збут, обіг, ремісія.

2. Назви операцій, пов'язаних iз фінансовою системою, капіталовкладеннями та позиками: інвестиц̧ія, мораторій, санац̧ія, санкц̧ія.

3. Назви, пов'язані 3 виробничим процесом: надвиробництво, перевиробництво, редукиія, тейлоризм.

4. Найменування суб’єктів економічних відносин: виробник, монополіст, продуцент.

5. Назви об’єднань, організацій: картель, монополія, трест.

Як показав матеріал дослідження, економічна термінологія в СУМ-20 розширилася більше ніж у два рази. У зв'язку зі зміною політичної й економічної ситуації в нашій державі, переходу до ринкової економіки, розвитку фінансової сфери з'явилося багато запозичених термінів на позначення: 
1) суб’єктів економічних відносин (ДЕКХо́ЛДЕР, а, ч., екон. Службовець біржі, який збирає доручення у клієнтів, а потім розподіляє їх між брокерами; ДжО́БЕР, а, ч., екон. 1. Біржовий клерк, який здійснює операції за власний рахунок і може укладати угоди тільки 3 іншими біржовими посередниками; КОНСИГНА́ТОР, а, ч., екон. Посередник в експорті товарів; МІНОРИТА́РІЙ, я, ч. 1. екон. Акціонер, який має неконтрольний пакет акцій і мінімум прав серед інших акціонерів);

2) об’єднань, організацій (АДХОКРА́ТІЯ, ї, ж., екон. Організаційна структура, яка займається новими для фірми питаннями i $\epsilon$, як правило, тимчасовою; ВЕ́НЧУР, а, ч., екон. .. 2. Підприємство малого бізнесу, що займається дослідно-конструкторськими розробками, винаходами і т. ін.; Джо́БЕР, а, ч., екон. .. 2. Фірма, що скуповує товари для швидкого перепродування; ДЕТЕРМІНА́TОР, а, ч. .. 2. екон. Незалежна організація, що має право на проведення експертизи міжнародного інвестиційного проекту спільного впровадження).

Зважаючи на близькість економічної й фінансової галузей, у їхньому складі $\epsilon$ частина спільної лексики (авераж, аверажний, безфондовий, вальваиія, дилінг, дилінговий, диспонент, диспонування, диспонувати та ін.). В одинадцятитомному Словнику зафіксовано чотири таких слова.

Багато термінів економіки, так само як і історії, зазнали змін через перехід держави до нового суспільно-політичного ладу та інших соціально-економічних відносин (див. табл. 18.2).

Таблиця 18.2

\begin{tabular}{|l|l|}
\hline \multicolumn{1}{|c|}{ СУМ-11 } & \multicolumn{1}{|c|}{ СУМ-20 } \\
\hline $\begin{array}{l}\text { БІЗНЕС, у, ч. Комерційна, біржова } \\
\text { або підприємницька діяльність як } \\
\text { джерело наживи в капіталістич- } \\
\text { ному світі. }\end{array}$ & $\begin{array}{l}\text { БІЗНЕС, у, ч. 1. Підприємницька діяльність, } \\
\text { спряована на отримання прибутку. }\end{array}$ \\
\hline $\begin{array}{l}\text { ДЕПРЁСІЯ, ї, ж... } \\
\text { 2. Застій в економіці } \\
\text { капіталістичних країн. }\end{array}$ & $\begin{array}{l}\text { ДЕПРЕ́СІЯ, ї, ж... } \\
\text { 2. екон. Застій у виробництві, торгівлі або } \\
\text { інших сферах життя суспільства; стагнація. }\end{array}$ \\
\hline
\end{tabular}


НАДПРИБУ́ТОК, тку, ч., ек. Прибуток, що значно перевершує середню норму прибутку в капіталістичному суспільстві.
НАДПРИБУ́ТОК, тку, ч., екон. Прибуток у господарстві, що значно перевершує середню норму прибутку; додатковий прибуток.

На відміну від СУМ-11 іменникова лексика в СУМ-20 становить близько сімдесяти відсотків від усієї термінології цієї галузі (у СУМ-11 - п’ятдесят відсотків). Це запозичені одиниці, що активно поповнили лексичний склад української мови у зв'язку 3 розвитком світової економіки i iї активним входженням до пострадянського простору.

У СУМ-20 з’явився ряд термінів для фіксації найменувань у широкій за своїм спектром сфері діяльності - маркетингу: банер, бренд, брендинг, маркетинг, демаркетинг.

Як і в інших терміносистемах, у музиці основу становить іменникова лексика. Вона позначає музичні твори, темпи, інструменти. Значна кількість таких слів є термінами італійського походження. Це переважно невідмінювані іменники середнього роду на -о (APIÓ30, невідм., с., муз. Невелика арія, що має наспівноречитативний характер; МУРМУРА́НДО, невідм., с., муз. Спів із закритими устами; СКЕ́РЦО, невідм., с., муз. Невеликий музичний твір у швидкому темпі 3 підкресленим ритмом).

Чимало в досліджуваній царині також прислівників на позначення темпів виконання музичних творів (ПІАНІ́ССІМО, присл., муз. Дуже тихо, ще тихіше, ніж піано (про силу звуку при виконанні музичного твору); ПІА́НО, присл., муз. Тихо (про силу звуку при виконанні музичного твору); ФОРТІ́ССІМО, присл., муз. Дуже сильно, гучно, голосніше, ніж форте (про звучання голосу, музичного інструмента при виконанні музичного твору) $)^{160}$.

Ще однією особливістю цієї галузі $є$ наявність і запозичених, i власне українських складних термінів, першою частиною яких є найменування кількості, а також назв, похідних від числівників (багатоголосся, двоголосся, одноголосся, поліфонічний, тритон, чверть, квінта, секстет, секста, териеет; двотактний, чотиритактний).

${ }^{160}$ Правопис реєстрових слів збережено. 
Музичні терміни досить уживані й поза межами своєї терміносистеми, що спричиняє їх детермінологізацію: «...популярність і поширеність музики як виду мистецтва сприяли тому, що велика кількість музичних термінів посіла стійке місце в загальнолітературній мові, втративши нерідко на рівні загального функціонування своє суто наукове значення» ${ }^{161}$.

Загалом термінологія з музикознавства, зафіксована в СУМ-11, поділяється на п’ять тематичних груп:

1. Назви музичних темпів: адажіо, алегрето, алегро, анданте, престо.

2. Назви музичних творів: арія, аріозо, рапсодія, серенада.

3. Найменування музичних інструментів: вентиль, регістр, секунда, трость, челеста.

4. Назви на позначення музичних звуків, мелодій: дисонанс, звук, тоніка.

5. Назви, що стосуються нотної грамоти: ключ, ліга, фермата.

Термінологія з музикознавства в СУМ-20 розширилася трохи більше ніж наполовину та суттєво поповнилася новою лексикою, яка йменує:

1) музичні темпи (АНДАНТИ́НО, муз. 1. присл. Повільно, дещо швидше, ніж анданте (про темп виконання музичного твору); ВІВА́ЧЕ, муз. 1. присл. Швидко, жваво (про темп виконання музичного твору, швидший від алегро, але повільніший від престо); Ві́вО, присл., муз. Жваво, швидко (про темп виконання музичного твору, близький до віваче); ЛЕ́НТО, муз. 1. присл. Повільно, швидше за ларго);

2) музичні інструменти (БО́МБІКС, а, ч., муз. Старовинний грецький духовий музичний інструмент; ВІБРАФО́Н, а, ч., муз. Ударний музичний інструмент, що складається з розміщених у два ряди і поєднаних із набором трубок-резонаторів металевих пластинок, по яких ударяють спеціальними паличками; КОБУ́3, а, ч., муз. Узбецький струнний смичковий музичний інструмент; МЕМБРАНОФО́Н, а, ч. Музичний інструмент, джерелом звуку якого $€$ коливна мембрана - шкіра тварин або синтетична плівка, натягнута на

${ }^{161}$ Панько Т. І., Кочан I. М., Мацюк Г. П. Українське термінознавство. Львів: Світ, 1994. C. 88 . 
циліндричний або конічний корпус, який також є резонатором інструмента та багато ін.);

3) музичні твори (ІНТРА́ДА, и, ж., муз. Інструментальна п’єса урочистого, величного характеру (вступна частина сюїти); КАМПАНЕ́ЛА, и, ж., муз. Музична п’єса, в якій відтворюється звучання дзвіночків; НОВЕЛЕ́ТА, и, ж. 1. муз. Невеликий музичний твір (здебільшого для фортеп'яно) без усталеної точної форми ліро-епічного, іноді драматичного характеру).

Особливістю музичної термінології $є$ поширена внутрішньосистемна полісемія. Це переважно терміни, що позначають одночасно музичні темпи й частини музичних творів (АНДАНТЙНО, муз. 1. присл. Повільно, дещо швидше, ніж анданте (про темп виконання музичного твору). 2. знач. ім., невідм., c. Музичний твір або його частина, що виконується в такому темпі). Хоча багатозначність властива не тільки цим поняттям. Зафіксовано навіть терміни 3 трьома значеннями, наприклад: БУРДО́Н, а, ч., муз. 1. Неперервний і незмінний за висотою звук відкритих струн щипкового і смичкового інструментів, басових трубок волинки та ін. 2. Не скорочувані пальцями під час гри струни щипкових i смичкових музичних інструментів. 3. Басовий регістр органа).

У цій царині зафіксовано також багато термінів іншомовного походження (переважно на позначення музичних темпів і творів) з іншим написанням у зв'язку зі зміною правопису 1993 року. Наприклад: алегретто - алегрето, інтермещцо інтермецуо, піаніссімо - піанісимо, фортіссімо - фортисимо тощо.

Музична термінологія поповнилася ще однією тематичною групою музичні стилі: бард-рок, бібоп, біг-біт, джаз-рок, диско, ламбада, лаунж тощо.

Технічну термінологію одинадцятитомного словника утворюють іменники, значна частина прикметників і порівняно невелика кількість дієслів. Найбільше термінів уживається на позначення приладів та пристроїв (трайлер, ущзільнювач, хобот, циліндр, штовхач, штуцуер, шукач). Лексика цієї галузі відзначається наявністю омонімії, у деяких випадках навіть у межах самої терміносистеми. Наприклад: БЛок'ㄹ, а, ч., техн. Простий механізм для підняття важких предметів, що має форму колеса (на осі) з жолобом, через яке перекинуто ланцюг, канат і т. ін. та БЛОк ${ }^{2}$, а, ч. 1. техн. Окрема, незалежна частина споруди, машини і т. ін., 
що складається також з окремих елементів або деталей; БУ́чЕННЯ1

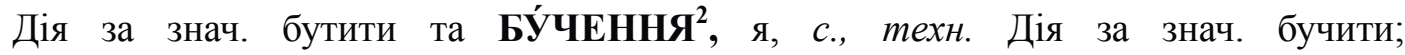
ВИБУ́чУВАТИ ${ }^{1}$, ую, уєш, недок., ВИ́БУТИТИ, учу, утиш, док., перех., техн. Заповнювати яму бутовою кладкою доверху та вИБу́чуУВАТИ², ую, уєш, недок., Ви́БУчити, чу, чиш, док., перех., техн. Вимочувати, видержувати в лугу.

Хоча техніка досить об’ємна за кількістю термінів (посідає друге місце після історичної лексики), проте тематично розгалужена значно менше, ніж деякі попередні кількісно вужчі галузі знань. У ऑï складі можна виділити п’ять тематичних груп:

1. Назви пристроїв, приладів: автоклав, агрегат, барабан, болторіз.

2. Назви на позначення процесів, явищ: агломерація, вулканізація, ерозія.

3. Найменування спеціалістів технічної галузі: зварник, регенераторник, розкарбовувач, розклепник.

4. Назви будівель, споруд: профілакторій, стапель, кочегарка.

5. Назви на позначення речовин та їхніх складників: присадка, сало, флюс.

Технічна терміносистема в СУМ-20 (збільшилася на 81 \%) поповнилася в основному за рахунок слів, що позначають:

1) прилади, пристрої (АДСО́РБЕР, a, ч. Пристрій, у якому здійснюють адсорбцію; БРУСКОТРИМА́Ч, á, ч. Пристрій для закріплення, підтримування брусків; ВІБРОБУ́Р, а, ч. Прилад для буріння, що використовує механічні коливання високої частоти для послаблення чи повного порушення зв'язку між частинками (зернами) речовини; ГІДРОБУ́Р, а, ч., техн. Пристрій, який утворює лунки для саджанців за допомогою струменя води; МАСТИЛОВИМІ́РНИК, а, $ч$. Пристрій або прилад для вимірювання рівня заповнення мастилом резервуарів, мастилобаків і т. ін.);

2) спеціалістів цієї галузі (ВІДЖИМА́ЛЬНИК, а, ч. Робітник, який займається віджиманням; ЕЛЕКТРОБУРИ́ЛЬНИК, а, ч. Робітник, який здійснює електробуріння; НАЛА́ГОДЖУВАЛЬНИК, а, ч. Робітник, який налагоджує машини, верстати, механізми і т. ін.).

Отже, згідно з проаналізованим матеріалом, найбільше термінологічною лексикою в Словнику української мови у 20-ти томах порівняно зі Словником 
української мови в 11-ти томах поповнилися такі великі галузі: медицина близько 1287 одиниць (більше 200 \%), історія - близько 789 одиниць (понад 80 \%), біологія - близько 781 одиниці (приблизно 300 \%), геологія - близько 683 одиниць (понад $200 \%$ ), фізика - близько 494 одиниць (близько 150 \%), лінгвістика близько 445 одиниць (понад $100 \%$ ) тощо.

\subsubsection{1. Терміни нових галузей знань у Словнику української мови у 20-ти томах}

У Словнику української мови у 20-ти томах, крім нової лексики, яка поповнила терміносфери, зафіксовані Словником української мови в 11-ти томах, 3'явилися терміни, що належать до галузей, яких у попередньому словнику не було представлено. Порівняно із СУМ-11 СУМ-20 розширив свій реєстр термінологією 3 інформатики, екології, окремо виділено палеонтологію, соціологію, а також уведено відповідні ремарки (інформ., екол., сои., палеонт.).

Через стрімкий розвиток комп'ютерної та обчислювальної техніки з'явилася нова наукова галузь - інформатика, що вивчає природу інформації, методи іiі отримання, зберігання, оброблення, передавання з використанням комп'ютерних технологій і прогресивних засобів комунікації. Швидке зростання інформаційного обміну у сфері культурних, наукових та технічних комунікацій викликало потребу в номінації значної кількості нових понять - продуктів пізнавальної та творчої діяльності людини, уточнення окремих термінів, а інколи й перебудови поняттєвого апарату наукових дисциплін і відповідних термінологій.

Отже, СУМ-20 суттєво поповнився термінологічною лексикою з інформатики, яка натепер посідає в ньому дев’яте місце серед інших галузей знань, що свідчить про стрімкий розвиток цієї наукової сфери. У термінології 3 інформатики наявні іменники, невелика кількість похідних прикметників і деякі дієслова. Це переважно терміни, які стосуються комп'ютерних технологій та інформаційних мереж.

Зафіксовані лексеми переважно однозначні, хоча $є$ й багатозначні, які, як правило, вживаються, ще в якійсь іншій галузі. Наприклад: АНТИВі́рУС, у, ч. 1. фарм. Лікувальний препарат, який складається з фільтрату культур мікробів і має 
властивість затримувати розмноження саме того виду мікробів, із якого його одержали. 2.інформ. Програма, що виявляє вірус в пам'яті комп'ютера i нейтралізує його дію; ДЕСТРУКТОР, а, ч. 1. біол. Організм, який у процесі життєдіяльності перетворює органічні залишки в неорганічні речовини. 2. інформ. Спеціальний метод, що слугує для деініціалізації об’єкта, наприклад, для звільнення пам’яті.

Крім багатозначних слів, у цій галузі зафіксовано кілька термінів, що є омонімічними з одиницями інших царин (бim (інформатика й музика), вінчестер (військова лексика й інформатика), дек (морська лексика й інформатика), демон (релігія, міфологія й інформатика), директорія (історія й інформатика), сайт (інформатика й біологія) тощо).

У складі термінології з інформатики нараховується сім тематичних груп:

1. Назви програм: антивірус, архіватор, браузер, драйвер.

2. Назви на позначення мов програмування: автокод, бейсик, паскаль.

3. Найменування частин комп'ютера: відеокарта, вінчестер, джсойстик, дисковід.

4. Найменування фахівців інформаційної галузі: адміністратор, блогер, веб-адміністратор, веб-майстер.

5. Назви одиниць вимірювання інформації: біт, гігабайт, кілобайт, терабайт.

6. Назви процесів: верифікація, індексація, інсталяц̧ія.

7. Назви понять, що стосуються Інтернету: веб-сайт, веб-сервер, вебсторінка, Інтернет.

Термінологія з екології складається переважно 3 іменникової лексики на позначення розділів цієї науки, екологічної безпеки, а також із кількох похідних прикметників. Особливістю поданих екологічних понять є їхня однозначність, окрім одного слова: БІОЦИ́кЛ, у, ч., екол. 1. Найбільший екологічний підрозділ біосфери (суходіл, море та внутрішні водойми). 2. Закономірна зміна фаз або стадій розвитку організму. 
Майже всі зафіксовані в СУМ-20 терміноодиниці вживаються 3 першою частиною біо- (біогеоценологічний, біогеоценологія, біогеоценотичний, біогумус, біоекономіка, біоекос, біокліматичний, біокліматологія тощо).

Екологічну термінологію в реєстрі Словника можна поділити на три тематичні групи:

1. Назви розділів екології: біогеоценологія, біоекономіка, біокліматологія.

2. Назви понять, що стосуються живих організмів: біоекос, біом, біомаса, бiomun.

3. Назви понять, що пов'язані зі збереженням життя на Землі: авторегулячія, біоочищення, біотестування.

Також в СУМ-11 було зафіксовано кілька слів на позначення соціологічної термінології, проте в СУМ-20 завдяки розширенню складу цієї галузі знань було введено відповідну ремарку. Хоча зазначена терміносфера поки що не нараховує багато одиниць. Лексика із соціології, зафіксована у двадцятитомному словнику, вживається переважно на позначення певних суспільних течій, процесів, рухів, груп тощо (вождизм, депопуляція, егрегор, етнізація, етнікос і т. ін.).

Зважаючи на збільшення в сучасній науково-популярній, фантастичній літературі тощо кількості понять, що стосуються вимерлих тварин і рослин, запропоновано виокремити палеонтологію як окрему галузь біологічної науки. Натомість у Словнику української мови в 11-ти томах було виділено такі підрозділи, як ентомологія, іхтіологія, орнітологія, а в Словнику української мови у 20-ти томах лексику названих галузей подано в складі зоології, оскільки виокремлення тільки цих підрозділів, на думку лексикографів, не зовсім логічне. До того ж досить часто лексеми, що належать до зазначених галузей, в одинадцятитомному словнику позначено ремаркою «зоол.» Лінгвістична термінологія, що розділялася в СУМ-11 двома ремарками - «лінгв.» і «грам.» (лінгвістика і граматика), у СУМ-20 позначатиметься лише «лінгв.».

Отже, термінологія як невід’ємна частина загальнолітературної мови є суттєвим складником реєстрів Словників української мови в 11-ти й 20-ти томах. Аналіз цих двох праць із погляду представлення термінів як систематизованої сукупності лексичних одиниць на позначення спеціальних понять науково- 
теоретичної та професійно-практичної діяльності людини дає змогу побудувати модель мовної картини розвитку й збагачення української термінології. Об’єктом нашого дослідження в цьому розділі стали найбільші за обсягом і кількістю тематичних груп терміносистеми в обох працях. Порівняльний аналіз галузевої лексики в СУМ-11 і СУМ-20 показав, що ії склад у другому збільшився майже вдвічі. Як бачимо з дослідження, найбільшою кількістю нових терміноодиниць поповнилася медична галузь. Значно розширила свій склад біологічна терміносистема, історія, лінгвістика та ін. Серед нових галузей знань, зафіксованих у СУМ-20, провідне місце посідає інформатика.

\section{3. Шляхи й способи поповнення термінології в Словнику української мови у 20-ти томах}

\subsection{1. Особливості термінологічного словотворення}

Розвиток мови зумовлений значною мірою розвитком її словотвірної системи, становленням нових словотвірних моделей слів або актуалізацією забутих, заміною старих чи зменшенням їхньої продуктивності й багатьма іншими чинниками. Установлення тенденцій розвитку словотворчих процесів, удосконалення теорії й практики лексикографії завжди були найважливішими проблемами мовознавчих досліджень.

Розгляд галузевої термінології як частини системи загальнолітературної мови потребує грунтовного аналізу не тільки 3 лексико-семантичного, а й зі словотвірного погляду для з'ясування структури, специфічних ознак, а також загальних механізмів творення нових термінів.

Словотворення термінологічної лексики як складника мовної системи висвітлено певною мірою в працях багатьох науковців (Д. Лотте, В. Даниленко, О. Суперанської, Ф. Нікітіної, І. Кочан, Л. Симоненко, А. Д'якова та інших).

Термінологічна лексика є частиною загального словникового складу мови, тому на ній також позначається дія всіх законів мови, зокрема й словотвірних. Для 
нових об'єктів номінації використовують наявні в мові способи словотворення, лексичні ресурси національної мови, лексику інших мов.

Розглядаючи деривацію термінів, науковці звертають увагу на піi певні специфічні особливості. Так, досліджуючи термінологічну систему російської мови, В. Даниленко з'ясувала найтиповіші для термінологічного словотворення ознаки. Зокрема, науковиця звертає увагу на створення термінів представниками конкретних галузей діяльності «...під тиском певної практичної необхідності» ${ }^{162}$. Проте це не означає, що термінологічна лексика зі своїх спеціальних ділянок ніколи не мігрує. Навпаки, значна частина одиниць дуже швидко стає загальновживаною, потрапляє в словники загальнолітературної мови. Але виникають терміни в професійному середовищі й уживаються в суто термінологічній функції тільки в науковій мові (у спеціальній літературі та в професійному спілкуванні ${ }^{163}$. Крім того, В. Даниленко зауважує, що словотвірний акт утворення спеціального найменування дещо складніший від аналогічного процесу для загальновживаного слова. «Якщо для другого достатнім можна вважати використання одного з наявних способів словотворення, то для терміна необхідне ще словесне розкриття змісту термінологічної номінації, тобто дефініції поняття» ${ }^{164}$.

Важливою ознакою термінологічного словотворення $є$ також те, що цей процес завжди свідомий, а не стихійний. «Терміни, - зазначав свого часу Г. Винокур, - не «з'являються», а «придумуються», «творяться» у зв’язку 3 усвідомленням їх необхідності» ${ }^{165}$. Підтримують цю думку й українські науковці, зауважуючи, що «...однією з суттєвих особливостей спеціальної термінології є те, що вона найбілыш піддається свідомому втручанню носіїв мови в ії творення, вона становить найбільш керовану групу лексики літературної мови» ${ }^{166}$.

162 Даниленко В. П. Русская терминология: Опыт лингвистического описания. М., 1977. С. 91. 163 Там само.

164 Даниленко В. П. Русская терминология: Опыт лингвистического описания. М., 1977. С. 94.

165 Винокур Г. О. О некоторых явлениях словообразования в русской технической терминологии. Труды МИФЛИ. Сборник статей по языковедению. М., 1939. Т. V. С. 24.

${ }^{166}$ Національні та інтернаціональні компоненти в сучасних терміносистемах / [Л. О. Симоненко, С. О. Соколова, І. В. Коропенко, М. П. Годована та ін.]; відп. ред. Л. О. Симоненко. К. : Наук. думка, 1993. С. 97. 
Важливою ознакою словотворення галузевої лексики $\epsilon$ те, що функції словотворчих морфем у термінології дещо ширші, ніж у загальнолітературній мові. Оскільки такі морфеми спрямовані на вираження певних значень у певних терміносистемах, то в термінології вони виконують класифікаційну функцію.

Дослідниця словотвірних особливостей української термінології Ф. Нікітіна зробила висновок, що виникнення нових словотвірних моделей $є$ характерним і для загальнонаціональної, і для термінологічної лексики. Науковиця зазначає також, що на українську термінологію має вплив російська наукова й технічна термінологія. «Під впливом російської термінології в українській утворюються терміни-прикметники від іменників із суфіксом -ість, такі, як імовірнісний, ємнісний, иілісний та деякі інші» ${ }^{167}$.

Однак останніми роками можемо спостерігати й зворотний процес: українська лексика, зокрема й термінологічна, позбавляється від необгрунтованих запозичень із російської мови. Яскравим прикладом цього є, скажімо, обмеження у вживанні віддієслівних іменників із суфіксом -к- (вибілка, вигонка, виковка, вичистка і т. ін.), натомість активніше використання слів із формантом -нн- (-анн-, -янн-, -енн- і под.) (вибілювання, розроблення, оброблення тощо). Можемо спостерігати й витіснення ад’єктивів на -чий, що походять від активних дієприкметників теперішнього часу, прикметниками на -льн- (анестезувальний замість анестезуючий, запам'ятовувальний замість запам 'ятовуючий і т. ін.) тощо ${ }^{168}$.

Ще однією особливістю термінотворення $є$ те, що в сучасній термінології збільшується кількість інтернаціональних термінів, побудованих, зокрема, за допомогою терміноелементів класичних мов. Відносна семантична однозначність цих терміноелементів дозволяє в переважній більшості випадків уникати полісемії. До того ж у галузевих терміносистемах знаходять поширення

${ }^{167}$ Нікітіна Ф. О. Семантичні та словотворчі проблеми сучасної термінології. К. : Вища школа, 1978. С. 12.

168 Докладніше про тенденції сучасного словотворення див, напр.: Тараненко О. О. Актуалізовані моделі в системі словотворення сучасної української мови (кінець ХX - початок XXI ст.). К. : Видавн. дім Д. Бураго, 2015. 248 с.; Кислюк Л. П. Словотвірна номінація в сучасній українській мові: система - узус - ідіолект: дис... доктора філогічних наук зі спец. 10.02.01 «Українська мова». К., 2018. 616 с. та ін. 
«гібридні» терміни, які сполучають у своєму складі інтернаціональні терміноелементи або афікси 3 морфемами рідної мови. «Гібридизація» може набувати різних форм: а) сполучення запозиченого або інтернаціонального кореня 3 незапозиченим афіксом: програмування, шліфувальник та ін.; б) сполучення запозичених або інтернаціональних афіксів 3 незапозиченим коренем або основою: антигромадський, ультракороткий, мікровідстань та ін. ${ }^{169}$.

Отже, словотворення термінологічної лексики відбувається переважно за тими самими принципами, що й загальновживаних слів. Проте функції словотворчих морфем у термінології ширші, оскільки виконують класифікаційну функцію. Також під час творення термінів більше залучаються інтернаціональні елементи. Зважаючи на те, що терміни значною мірою є штучними лексикосемантичними утвореннями, процес їхнього словотворення $\epsilon$ завжди контрольованим, продуманим, і тому його смислова сутність повинна відтворити той обсяг інформації, ту суму наукових знань, які допомагають розкрити зміст поняття.

Оскільки саме термінологічна лексика у сучасному світі стала головним джерелом поповнення й розширення словникового складу будь-якої високорозвиненої національної мови, що $є$ наслідком науково-технічного прогресу, то «...звідси випливає необхідність виявити, які словотвірні моделі, які словотворчі форманти загальновживаної мови використовуються в термінологічній системі, який характер iii взаємодії із загальновживаною мовою» ${ }^{170}$.

\subsection{2. Морфологічна деривація}

Відомо, що більшість слів української мови утворено за допомогою морфологічного способу. Не становить тут винятку й галузева лексика. Як

${ }^{169}$ Нікітіна Ф. О. Семантичні та словотворчі проблеми сучасної термінології. К. : Вища школа, 1978. С. 14.

${ }^{170}$ Чернобай Л. И. О взаимодействии терминологического и общелитературного словообразования (на материале неологизмов французского языка). Термины в языке и речи: межвуз. сб. Горький: ГГУ, 1985. С. 52-53. 
засвідчують лінгвістичні праці, загальні закономірності морфологічного словотворення єдині для всієї мови загалом. Утворення термінів і слів загального вжитку відбувається переважно за тими самими словотвірними моделями.

Однак щодо термінології морфологічний спосіб, як зауважує В. Даниленко, має низку важливих відмінних ознак. Насамперед дослідниця наголошує, що в термінотворенні загалом значно ширшим і різноманітнішим $є$ коло засобів, що використовуються як терміноелементи. Царині термінолексики властиве набагато ширше в порівнянні із загальнолітературною мовою вживання власних імен у ролі похідних основ. Крім цього, за словами В. Даниленко, «...для термінологічної деривації характерне активніше, ніж у загальнолітературному морфологічному словотворенні, використання всіх можливих засобів і прийомів словотворення. У термінології в однаковій мірі активні й суфіксація, і префіксація, і суфіксація 3 префіксацією, а також словоскладання, словоскладання з афіксацією...» ${ }^{171}$.

На думку українських учених Т. Панько, І. Кочан, Г. Мацюк, у творенні термінології української мови на основі морфологічного способу провідне місце займає афіксація. Саме в «...морфологічній структурі слова-терміна, утвореного шляхом афіксації, органічно закладені основи структурної систематизації, які мають першочергове значення для термінології» ${ }^{172}$.

Як показав матеріал дослідження, морфологічний спосіб (близько 80 \%), зокрема афіксація, посідає центральне місце й під час творення нових термінів, зафіксованих у Словнику української мови у 20-ти томах. Морфологічний словотвір галузевої лексики розглядатимемо за частиномовним принципом, оскільки в тлумачному словнику вона представлена основними самостійними частинами мови, які мають своєрідні дериваційні особливості.

171 Даниленко В. П. Русская терминология: Опыт лингвистического описания. М., 1977. C. 113 .

172 Панько Т. І., Кочан І. М., Мацюк Г. П. Українське термінознавство. Львів: Світ, 1994. C. 167. 


\subsubsection{1. Основні способи творення термінів-іменників}

Згідно з результатами дослідження, у Словнику української мови у 20ти томах нова іменникова термінологія становить близько 73 \% від усієї галузевої лексики, утвореної за допомогою морфологічної деривації. Серед способів словотворення значною продуктивністю відзначаються суфіксальний, префіксальний способи й композиція, дещо нижча продуктивність спостерігається в суфіксально-префіксального способу та абревіації.

Характерною особливістю іменникових термінів $\epsilon$ те, що в їхньому складі наявні іншомовні афіксальні одиниці, утворені від однієї лексичної основи. Внутрішня структура однієї групи таких слів виявляєьься мотивованою в українській мові, а структура іншої залишається немотивованою. Мотивованими в словотворчому відношенні $є$ такі афіксальні запозичення, основа яких чітко сприймається як тотожна 3 основою інших наявних уже в українській мові семантично споріднених слів. До немотивованих афіксальних утворень від однієї основи іншомовного походження належать насамперед такі нові терміни, основа яких не входить до складу іншомовних слів, що були відомі вже в українській мові раніше ${ }^{173}$.

\subsubsection{1. Суфіксальний спосіб творення термінів-іменників}

Високу продуктивність в іменниковому термінологічному словотворенні виявляє суфіксальний спосіб, за допомогою якого утворюються нові терміни на основі іменників, прикметників і дієслів.

\section{Відіменникові субстантиви}

Проведене дослідження продемонструвало, що більшу частину нових термінів у Словнику української мови у 20-ти томах, утворених за допомогою суфіксів, становлять відіменникові субстантиви. І це цілком зрозуміло, адже зміни в суспільному житті особливо потребують нових номінацій на позначення осіб, понять, явищ, предметів тощо.

${ }^{173}$ Науково-технічний прогрес і мова / відп. ред. В. М. Русанівський. К.: Наук. думка, 1978. C. 65. 
Під час творення дериватів, зокрема назв осіб, від іменників велику продуктивність виявив суфікс -ник (арбалетник, каротажник, колодник, ландшафтник, шаблонник, ясирник). Він уживається переважно в словах, що є назвами осіб за родом діяльності, соціальним становищем, званням тощо (апретурник, гранітник, грохотник, дренажник, елеваторник, електронник, макетник). Розглянуті найменування належать до різних галузей знання.

Досить продуктивним під час творення термінів, доданих у СУМ-20, $є$ суфікс -ист (-іст, -їст). Деривати цього типу словотворення поєднують осіб за родом занять, діяльності, фахом. Це переважно слова іншомовного походження на позначення термінолексики із царин спорту, філософії, музики тощо (авалісm, айкідоїст, альтист, антропоніміст, батутист, брасист, велоболіст, гедоніст, геотерміст, дзюдоїст, домбрист, етюдист, пенальтист).

Іменники на означення діяча, зафіксовані в СУМ-20, утворюються також за допомогою суфіксів -ер (-ор, -тор). Зазначені терміни становлять масив лексики 3 основами іншомовного походження й використовуються в різних галузях (атрибутор, блогер, вакцинатор). Також згадані суфікси вживаються на позначення знарядь, механізмів, приладів тощо, поширених переважно в технічній галузі (баластер, гідролізер, екструдер, інверсор, коліматор).

Частину іменників, зафіксованих у реєстрі СУМ-20, утворено за допомогою суфікса -к(а). Це субстантиви жіночого роду, що походять від іменників чоловічого роду й позначають особу як виконавця певної дії (за заняттям, професією і т. ін.), фахівця із чого-небудь: акціонерка, атлетка, болгаристка, брасистка, віндсерфінгістка, гольфістка, елліністка, каноїстка, кларнетистка тощо. Як показав аналіз, ці одиниці наявні в різних галузях, а особливо багато нараховується їх у спорті.

3 названим словотвірним значенням виступають також деривати із суфіксом -иц(я)/-ниц(я), що утворені від співвідносних назв чоловічого роду. Ці найменування належать переважно до спеціальної й технічної термінології, менше назв зі сфери спорту (брикетувальниця, вакуумниця,, віджимальниця, відпалювальниця, воднолижниця, гірськолижниця, гравіювальниця, декатирувальниця, держательниця). 
Невелику групу в Словнику української мови у 20-ти томах становлять деривати словотвірного типу із суфіксом -ець (-овець, -івець) у назвах осіб $з$ основним словотвірним значенням: «особа за належністю до ідеологічного, суспільного, політичного, релігійного і т. ін. напрямку, угруповання». Ці терміни зазвичай утворюються від власних імен та деяких абревіатур і вживаються переважно на позначення історичної лексики (абверівещь, мазепинещь, наливайківець, низовецьь).

У досліджуваному словниковому матеріалі зафіксовано невелику кількість термінів із суфіксом -щин(а)/-чин(а), -івщин(а), що утворені, як і частина дериватів із суфіксом -ець (-овець, - івець), здебільшого від власних імен історичних осіб, але, на відміну від попереднього типу, позначають історичні періоди, події, пов’язані з діяльністю особи, названої коренем слова (беріївщина, біронівщина, корніловщина, наливайківщиина).

Словотвірний тип із суфіксом -ств(о)/-цтв(о) належить до активних у досліджуваному матеріалі. За його допомогою від основ іменників утворено терміни, що вживаються на позначення стану, соціального становища, галузі виробництва, діяльності тощо (адвокатство, аудиторство, баронетство, віконтство, годинникарство, грибівництво, дилерство, донорство, емісарство, індиківництво, кошикарство, ливарництво).

Продуктивністю під час творення нових термінів-іменників відзначається також суфікс -ик(а) /-ік(а). До цього типу належать деривати, що позначають галузь науки, науковий напрям, сферу діяльності певної особи тощо (аксіоматика, біблеїстика, гідроніміка, морфеміка, патроніміка).

Досить активним є також словотвірний тип із суфіксом -изм (-ізм). Деривати iз зазначеним афіксом мотивовані іменниками на позначення власних і загальних назв (осіб, предметів тощо). Уживаються з такими основними значеннями: 1) наукове вчення, релігійний, суспільно-політичний і т. ін. напрям, течія, система поглядів (абсурдизм, бланкізм, брахманізм, ведизм, вішнуїзм, вождизм, гандизм, гонгоризм); 2) назва хвороби (аутизм, ботулізм, гашишизм, нарцисизм).

Частину термінологічної лексики Словника української мови у 20-ти томах становлять деривати словотвірного типу із суфіксом -ит (-іт), що є назвами 
захворювань людського організму, мотивованими назвою хворого органа, тканини. Зазначені найменування належать до медичної галузі (аортum, apmepiïm, бурсит, вагініт, везикуліт, вульвіт).

\section{Відприкметникові іменники}

Деривати, мотивовані прикметниками, на відміну від субстантивних, не мають великої кількості словотворчих суфіксів. У СУМ-20 зафіксовано два типи таких морфем.

Досить продуктивним в утворенні нових термінів $є$ суфікс 3 абстрактним значенням -ість. Із цією морфемою в СУМ-20 нараховується значна кількість відприкметникових іменників зі значенням якості, властивості, стану: автохтонність, аглютинативність, адгезивність, апокрифічність, апріорність, вербальність, вігільність, дедуктивність, дискретність, ізогональність, ізотропність, імплічฺитність, континуальність, мутагенність тощо. Названий афікс поширений у термінах, які належать до різних галузей знань.

Другий словотвірний тип із суфіксом -ізм (-изм), що має значення: «елемент певної системи, яку визначає мотивувальне слово», не є високопродуктивним. У СУМ-20 найбільше зафіксовано відприкметникових іменників із суфіксом -ізм (-изм) на позначення лінгвістичної (зокрема лексикологічної) термінології (білорусизм, болгаризм, галищзизм, радянізм, чехізм).

\section{Віддісслівні іменники}

Значну кількість термінів у двадцятитомному словнику становлять віддієслівні іменники, утворені суфіксальним способом, що виникли внаслідок розширення продуктивності власне українського суфікса -ач. Деривати, що належать до цього типу, утворюються переважно від дієслів недоконаного виду, насамперед префіксальних, i мають два основних словотвірних значення. Причому термінів із другим значенням зафіксовано суттєво більше: 1) особа як виконавець певної дії, названої дієсловом: вичитувач, відтискувач, відчужувач, зачіплювач; 2) предмет (механізм, пристрій, інструмент і т. ін.), за допомогою якого виконується дія: викорчовувач, випаровувач, випромінювач, відпарювач, 
відхилювач, запам'ятовувач, затінювач, кантувач, накопичувач. Поширені ці терміни переважно в технічній галузі.

Від дієслівних основ за допомогою суфіксів -ник (-льник) (причому другий афікс набагато продуктивніший) активно утворюються найменування 3 першим значенням дериватів попереднього типу. Це переважно назви, що поширені в техніці або кількох терміносферах: витравник, замірник, бальзамувальник, брикетувальник, віджимальник, візирувальник, завальцювальник, закріплювальник, налагоджувальник.

Високою регулярністю відзначаються також деривати iз суфіксом -нн(я) / -анн(я), -янн(я), -енн(я), -інн(я), -уванн(я), -юванн(я), -ованн(я), що становлять суттєву частину іменників-термінів, утворених від дієслів (i безпрефіксних, i префіксальних) із загальним значенням опредметненої дії (процесу): абортування, абсорбування, авізування, амальгамування, бандажування, бромування, валютування, декапування, затюковування, зашліфування, кадміювання, купелювання. Це переважно терміни, що вживаються на позначення спеціальної лексики й частково понять біологічної та фінансової галузей.

3 тотожним словотвірним значенням у СУМ-20 зафіксовано терміни із суфіксами -аці(я)/-яці(я), -ці(я), що утворилися від дієслів на -ува(ти) 3 основами іншомовного походження (авторизація, алергізащуія, архівація, буферизація, гридифікація, інституалізація, концеептуалізація). Ці одиниці належать до різних галузей знання.

\subsubsection{2. Префіксальний спосіб творення термінів-іменників}

Характерною особливістю іменникового термінологічного словотворення $є$ активність префіксації, причому вищу продуктивність мають запозичені префікси, широко вживані в попередні періоди розвитку української літературної мови (М. Жовтобрюх, О. Муромцева, А. Москаленко, В. Русанівський) і на сучасному етапі (Д. Мазурик, О. Стишов, С. Соколова). Префіксація як спосіб творення нових слів поступається суфіксації, хоча в останнє десятиліття іменникова 
префіксація стала активнішою. Це пов'язано з певними внутрішньомовними та позамовними чинниками, що сприяють активізації в українській мові багатьох іншомовних морфем. Запозичені препозитивні одиниці на зразок анти-, архі-, де-, контр-, ультра-, екс- та інші стали виконувати роль префіксів, посівши помітне місце в системі української іменникової префіксації. Активне залучення подібних іншомовних елементів у сучасне українське словотворення сприяє загальній активізації префіксального способу творення іменників.

У досліджуваному матеріалі значну продуктивність серед власне українських префіксів виявив префікс над-, що вживається на позначення вищого ступеня градації якості якої-небудь субстанції. Значна кількість таких термінів функціонує в астрономії, фізиці, біології (надгалактика, надгігант, надзірка, надклас, надмолекула, надряд, надтип, надцарство). Префікс пере-, який указує на повторність дії або явища, має нижчу продуктивність і бере участь у творенні лексем, що належать до технічної та інших царин (перемодулящія, переохолоджувач, перепромисел, перепростій).

До поширених запозичених іменникових префіксів, що беруть участь у творенні сучасної української термінології (в СУМ-20) належать такі: анти- зі значенням протилежності чому-небудь; як складник різногалузевих термінів (антибільшовизм, антигормон, антидетонатор, антиелектрон, антикомунізм, антимистецтво, антинейтрон, антироман, антисвіт, антиядро); ана- - означає рух угору, підсилення, повторну або зворотну дію. Значна частина зазначених термінів належить до біологічної галузі (анагенез, анатоксин, анафаза, анафронт); гіпер- - указує на перевищення норми, межі; широко вживається як складник медичних, біологічних (гіперактиващія, гіпервентиляція, гіпервітаміноз, гіпермоторика, гіперпігментація, гіперсекреція, гіперфункція) та менше фізичних (гіперзвук, гіпер'ядро, гіперфрагмент) термінів, лексики 3 інформатики (гіперзв'язок, гіперконтекст, гіперсередовище); гіпо- - позначає заниження норми, межі (антонім до гіпер-). Як і попередній префікс, бере участь у творенні медичних термінів, а також найменувань на позначення фізіологічних процесів (гіпобіоз, гіпогалактія, гіпоглікемія, гіподинамія, гіпотермія, гіпофункиія); де/дез - уживається в термінах, які називають опредметнені дії та процеси, що є 
протилежними до названих мотивувальними словами. Лексика 3 аналізованим афіксом поширена в лінгвістичній, економічній, біологічній та інших галузях (дедраматизація, демаркетинг, демутація, депрефіксачія, десуфіксаиія, дерусифікація, дезадаптац̧ія, дезоксидація, дезурбанізм); прото- - означає первинність того, що названо мотивувальним словом. Префікс широковживаний у терміноодиницях астрономічної галузі (протогалактика, протозірка, протозоологія, протопланета, протосонцее); ре- - переважно в іменниках, які мотивуються як відповідними безпрефіксними іменниками, так і префіксальними твірними дієсловами. Цей префікс уживається в словах на позначення повторності якоїсь дії, явища, названих мотивувальним словом, і поширений в економічній термінології (реакцептація, редублеман, реінвестиція, реновація); суб- - активний під час творення відіменникових субстантивів i позначає: 1) поняття, що перебувають у безпосередньому взаємозв'язку 3 тими, що названі мотивувальними словами (субакорд, субарктика, субознака); 2) поняття, які стосовно названих мотивувальними словами є нижчими (субвелетень, субкарлик, субконтроктава, субмотив); 3) неповноту вияву тих якостей, що є в мотивувальному слові (субдепресія). Слова з розглянутим формантом поширені в музичній та астрологічній термінологіях; супер- - означає поняття, що має вищу якість, властивість або підсилену дію в порівнянні 3 мотивувальним словом. Терміни із цим префіксом переважають у фізичній $\mathrm{i}$ математичній терміносистемах (супергравітація, суперграфіка, супердивіденд, суперконцентрат, суперсиметрія, суперструна); ультра- - указує на дуже високий ступінь вияву ознаки в якомусь понятті, названому мотивувальним словом. Поширений у біологічній, фізичній царинах та в термінології, що належить до кількох галузей знань (ультраакустика, ультравірус, ультраімперіалізм, ультраміноліт, ультраструктура, ультрафільтр, ультрацентрифуга).

Префіксально-суфіксальний та безафіксний способи творення іменників $є$ малопродуктивними, тому в цій праці розглядати їх не будемо. 


\subsubsection{3. Словотвір складних термінів-іменників}

У процесі поповнення й розширення термінологічного складу Словника української мови у 20-ти томах важливе місце посідає творення складних слів, які $\epsilon$ найекономнішим засобом номінації. Вони свідчать про наявний у мові закон збереження лінгвістичної енергії, що є важливим чинником у період значного розширення інформаційного пласту. Дія цього закону виявляється в тому, що носії певної мови відбирають найраціональніші для спілкування мовні засоби, що відповідає прагненню сучасного суспільства до збільшення інформативності тексту за рахунок його скорочення, а також прагматичним настановам - економії площі друкованої продукції та часу усних повідомлень. Яскравим прикладом цього процесу є активне поповнення СУМ-20 новими складними термінами. Оскільки складні одиниці мають дві й більше твірних основи, то вони містять значну кількість інформації, яка економно поєднується в утворених номінаціях. Дослідження матеріалу демонструє, що нові складні терміни, зафіксовані в СУМ20, утворюються за допомогою юкстапозиції (словоскладання) й композиції (основоскладання).

\section{Словоскладання (юкстапозиція)}

У реєстрі Словника української мови у 20-ти томах зафіксовано значну частину нових термінів, утворених на основі юкстапозиції (словоскладання).

Для юкстапозитів характерним є складання компонентів без сполучних голосних, стягнення словосполучення в одне слово, як правило, без зміни форми його складників ${ }^{174}$.

За допомогою юкстапозиції утворюються слова, що мають написання разом і через дефіс. У складі нових термінів 20-томного словника зафіксовано обидва типи таких одиниць.

Серед складних термінів, що пишуться разом, можна виділити слова, що належать переважно до хімічної галузі: бензил- (бензилпеніиилін, бензилхлорид, бензилцелюлоза); бутил- (бутилацетат, бутилкаучук); вініл- (вінілацетат,

${ }^{174}$ Кудрявцева Л. А. Моделирование динамики словарного состава языка. 2-е изд., испр. К.: ИПЦ «Киевский университет», 2004. С. 132. 
вінілбензол, вінілфосфат, вінілхлорид); метил- (метилацетилен, метилбензол, метилтестостерон, метилхлорид, метилцелюлоза).

Значно більше за галузевою різноманітністю зафіксовано нових термінівюкстапозитів, що пишуться через дефіс. Це, наприклад, слова 3 такими компонентами: банк- - частина юкстапозита, що $е$ складником термінів фінансової сфери (банк-акиеептант, банк-гарант, банк-дилер, банк-еквайр, банкемітент, банк-кореспондент, банк-правонаступник); бета- - перша частина складних слів, що використовується для творення переважно термінів із фізики та інформатики (бета-версія, бета-діагностика, бета-розпад, бета-спектрометр, бета-тестер, бета-частинка); блок- - препозитивний компонент складних утворень - термінів переважно будівельної галузі (блок-картер, блок-квартира, блок-кімната, блок-контакт, блок-контейнер, блок-корпус, блок-схема); вакуум- - перша частина складних слів, що вживаються в основному на позначення спеціальних приладів, механізмів (вакуум-екстрактор, вакуумекстракція, вакуум-камера, вакуум-насос, вакуум-фільтр); веб- - перший компонент складних найменувань, пов'язаних із глобальною мультимедійною системою, які належать до царини інформатики (веб-браузер, веб-вузол, вебграфіка, веб-дизайн, веб-портал, веб-сайт, веб-сервер, веб-сервіс, веб-сторінка); гамма- - перша частина складних слів у термінах переважно фізичної галузі (гамма-апарат, гамма-еквівалент, гамма-залізо, гамма-квант, гамма-сигнал, гамма-сплеск, гамма-терапія); генерал- - уживається як частина слова на позначення військових чинів (генерал-адмірал, генерал-лейтенант, генералмайор, генерал-полковник, генерал-фельдмаршал); дельта- - препозитивна частина складних слів, що поширені у фізиці й інших галузях знання (дельтадеревина, дельта-залізо, дельта-метал, дельта-проміння, дельта-функція); інтернет- - перша частина складних одиниць, що відповідає слову «інтернет»; слугує для творення термінів інформатики (інтернет-браузер, інтернет-вузол, інтернет-графіка, інтернет-мережа, інтернет-програмування, інтернетсервер). 


\section{Композиція (основоскладання)}

Композити, зафіксовані в СУМ-20, утворено здебільшого поєднанням іменникових основ. Сюди належать терміни-композити, обидві частини яких - це самостійні слова; композити, у яких перший компонент - скорочене слово, другий - самостійне; композити, у яких перший компонент - самостійне слово, другий - скорочене слово.

Серед композитів, обидві частини яких є самостійними словами, можна виділити терміни з такими найпоширенішими препозитивними компонентами: газо- - уживається переважно як складник спеціальних і технічних термінів, а також назв наукових розділів (газоаналізатор, газовимірювання, газовідведення, газодинаміка, газозварювання, газокомпресор, газоочищення, газорозподіл, газотурбіна, газохімія); скло- - уживається переважно в термінології будівництва в складі найменувань будівельних матеріалів (склокераміка, склокераміт, склокремнезит, склокристаліт, склопрофіліт, склорубероїд, склошлакопорит); тепло- - уживається як частина переважно фізичних і спеціальних термінів (тепловипромінювання, теплограма, теплоємкість, теплопередача, теплопостачання, теплоприймач, теплофізика); шлако- - уживається як перша частина складного слова в спеціальних термінах (шлаковата, шлаковідділення, шлаковловлювач, шлакодробарка, шлакопісок, шлакопемза, илакосховище).

У СУМ-20 міститься значна кількість термінів із першим компонентом основою невідмінюваного іменника радіо- (радіобуря, радіогалактика, радіогеологія, радіоконтроль, радіолуна, радіомаркер, радіопеленгування, радіопромінь).

Серед композитів 3 опорним компонентом, який відповідає самостійному слову, значне місце посідають утворення, характерні в основному для науковотехнічної термінології, 3 першим компонентом - скороченою основою чи зв'язаним коренем ${ }^{175}$.

175 Кудрявцева Л. А. Моделирование динамики словарного состава языка. 2-е изд., испр. К.: ИПЦ «Киевский университет», 2004. С. 140. 
Група термінів зі скороченими основами іменників або суфіксальних прикметників (переважно із запозиченими коренями) є однією 3 найпоширеніших у досліджуваному матеріалі.

Виявлено, що досить продуктивними під час творення нових іменниківтермінів $є$ такі скорочені компоненти: авто-- означає «автоматика, автоматичний»; є складником переважно спеціальної і технічної термінології (автовиклик, авторозвантажувач, автоспуск, автоштурман); аеро-- відповідає слову «повітряний»; уживається переважно в складі найменувань на позначення наукових дисциплін, а також методів лікування за допомогою повітря (аерогеологія, аероіонотерапія, аерокліматологія, аеронавігація, аеротерапія); вібро- - відповідає слову «вібраційний» і вживається як перша частина переважно технічних та будівельних термінів-композитів (вібробрус, віброголка, віброзонд, віброінструмент, віброкоток, вібромолот, віброплита, вібростенд, вібростіл, вібротравма, віброхвороба); електро- - від слова «електричний»; слова із цим компонентом належать до фізики та іi розділів (електроакустика, електроанестезія, електробаланс, електродуга, електроіскра, електрооптика, електросинтез); психо- - відповідає словам «психіка», «психічний» і вживається переважно в термінах на позначення медичних понять та розділів медицини (психогігієна, психосоматика, психотехніка, психофармакологія, психохірургія); радіо- - стосується радіації; уживається в основному у фізичній термінології (радіоактивачія, радіобуря, радіоджерело, радіосплеск); теле-- означає «здійснення на відстані»; уживається переважно в термінах на позначення фізичних пристроїв, приладів, часто зі складною другою частиною, що закінчується на метр- (телеамперметр, телевимикач, телевольтметр, телесигналізатор, телефотометр) та інші.

До цієї ж групи композитів 3 опорним компонентом, що відповідає самостійному слову, належать утворення зі зв’язаним першим компонентом іншомовного походження, який використовується тільки як зв'язаний корінь. Найпоширенішими компонентами в композитах-термінах цього типу є такі: авто- - український відповідник «само-» (автовакцинна, автоетнонім, автоімунітет, автоінтоксикація, автоінфекція, автокаталіз). Найчастіше 
зазначені слова трапляються серед медичних термінів, хоча зафіксовано одиниці 3 названим складником і в хімічній, лінгвістичній царинах; біо- - вказує на відношення до життя, життєвих процесів (біодобавка, біокераміка, біопродукт, біосистема, біотонус); гео- - перша частина складних слів, які використовуються на позначення наукових напрямів, що пов'язані із земною поверхнею, iï вивченням (геоакустика, геобіологія, геодинаміка, геоекологія, геоенергетика, геосфера); гетеро- - означає «різнорідність»; поширений у складі біологічних понять (гетерогенез, гетерозигота, гетероморфоз, гетеротермія); гідро- вказує на відношення до води; значна частина таких термінів позначає прилади, пристрої, механізми, що належать до технічної галузі (гідробур, гідродомкрат, гідромуфта, гідросепаратор, гідросистема, гідросуміш, гідроииліндр); гомо- означає «однорідність»; $€$ складником переважно біологічних термінів (гомозигота, гомойологія, гомопластика, гомотипія); макро- - перша частина складних слів, що позначає великі розміри, величини. Терміноутворення на іï основі поширені в біологічній царині (макроеволющуія, макросередовище, макроспора, макроцитоз); мікро- - препозитивний компонент, що означає «пов'язаний із вивченням дуже малих предметів, розмірів, величин». Терміни із цим компонентом найпоширеніші в біологічній галузі, інформатиці (мікромодуль, мікрокарта, мікрокод, мікрокомп'ютер, мікропроцесор, мікроспорангій, мікроспорофіл); моно- - перша частина складних слів зі значенням «який складається з одного, єдиного, що стосується до одного; одиничний». Визначити пріоритетну галузь, у якій поширені терміни з названим компонентом не можна, оскільки вони вживаються в різних наукових сферах (моноаміни, моноанестезія, моноблок, моновалюта, моногідрат, монодрама, монокристал, моносилабізм, моноцентризм); мульти- - перший компонент композита, що означає множинність; слова із зазначеним складником поширені в технічній термінології (мультивіза, мультипрограмування, мультирумпель, мультициклон); нано- препозитивний компонент для творення слів на позначення в числовому розумінні однієї мільярдної частини вихідної одиниці, у фізичному - будь-яких елементів, механізмів, конструкцій і т. ін. таких розмірів, а також усього, пов’язаного з ними (наноаналіз, нанобактерія, нанобіологія, нанодіагностика, наноекономіка, 
наномеханіка, нанореволющія, наносекунда, наносистема, наноструктура, наночастинка); нео- - означає «новий»; у термінах на позначення наукових напрямків, течій тощо (неоглобалізм, неоконфуцііанство, неоромантизм, неофрейдизм, неоязичниттво); полі- - означає «багато»; уживається переважно на позначення хімічних речовин (полібутадієн, поліізопрен, полікристал, полімінерал, поліпредикатив); псевдо- - зі значенням «вигаданий, несправжній»; найчастотніше вживання зафіксоване в математичній і фізичній терміносистемах (псевдобазиліка, псевдовектор, псевдографіка, псевдомонади, псевдоскаляр, nсевдосфера); стерео- - перша частина складних слів зі значенням «стереоскопічний звук, ефект»; слугує для творення термінів, що належать до кількох галузей (стереоавтограф, стереоізомер, стереомеханіка, стереооптика, стереопроектор).

Крім описаних вище, продуктивним типом композиції термінів є складання основ зі зв’язаним опорним компонентом. Одиниць, утворених таким чином, найбільше нараховано в науково-технічній термінології. У реєстрі СУМ-20 можна виокремити нові терміни 3 такими поширеними зв’язаними компонентами: -грама - уживається на позначення результатів запису чого-небудь за допомогою певних приладів; слугує для творення медичної й спеціальної лексики (бронхограма, везикулограма, віброграма, гемограма, каріограма); -графпозначає назви осіб за професією, що пов'язана з описом або записом чого-небудь (астрогеограф, біогеограф, зоогеограф, металограф), а також назви приладів, пристроїв, що записують що-небудь (актинограф, віброграф, електрограф, eліnсограф); -лог - друга частина складного слова в назвах осіб за професією (акиентолог, алерголог, венеролог, ембріолог, кліматолог, невропатолог); -метр складник термінів на позначення вимірювальних приладів (адаптометр, баротермометр, галактометр, детонометр, каліброметр, катетометр); -скоп уживається в назвах оптичних та інших приладів, інструментів, які використовують для дослідження, діагностики чого-небудь (у медицині й фізиці) (бароскоп, бронхоскоп, вентрикулоскоп, віброскоп).

Як показав проаналізований матеріал, у композитному словотворі значне місце посідають постпозитивні й деякі препозитивні компоненти із власне 
українськими складниками. Це терміни, обидві частини яких є самостійними словами, та терміни 3 першою частиною - самостійним словом, а другою зв'язаною основою:

-будування - уживається переважно в $\quad$ найменуваннях галузей промисловості (верстатобудування, двигунобудування, дизелебудування, елеваторобудування, турбінобудування); -знавство - друга частина складного слова, що позначає галузь знання, названу першою частиною (архівознавство, балетознавство, бібліографознавство, болотознавство, документознавство, газетознавство, країнознавство); -знавець - постпозитивний компонент, що вживається на позначення спеціаліста певної галузі знання (державознавець, зорезнавещьь, ландшафтознавещь, лісознавецьь, наукознавещь); -мір - друга частина композита в складі назв на позначення вимірювальних приладів (балансомір, бензиномір, звукомір, іономір, масомір, моментомір, нахиломір);

бого- - досить поширена перша частина, що вживається на позначення релігійних термінів (Боговтілення, Боголюдина, богоодкровення, богопоклоніння, Богочоловік); вітро- - уживається на позначення термінів, пов'язаних із вітром, його енергією; поширений у технічній термінології (вітроагрегат, вітрогенератор, вітроенергія, вітрозахист, вітропотенціал, вітроресурс, вітротехніка, вітротурбіна).

У СУМ-20 більшу частину складних термінів становлять одиниці, що обслуговують медичну галузь. Як засвідчує раніше проаналізований матеріал, найбільше у двадцятитомному словнику міститься саме понять медицини. Основоскладання - провідний спосіб творення цих термінів, що поєднує всі розглянуті вище типи (тобто утворення, обидві частини яких - це самостійні слова й найменування зі скороченим першим або другим компонентом). У складі проаналізованих терміноодиниць нараховується чимало таких, які належать і до ветеринарії.

У Словнику української мови у 20-ти томах зафіксовано композити з такими поширеними препозитивними компонентами: бронхо- - позначає поняття, що пов'язані із захворюваннями, дослідженням та лікуванням бронхів (бронхоаденіт, бронхограма, бронхопневмонія, бронхоскоп, бронхоспазм); вазо- - вживається для 
позначення понять, пов’язаних із судинами (вазографія, вазодилатин, вазоконстриктин, вазоневроз, вазоспазм); гастро- - перша частина складних термінів, що стосуються хвороб шлунка та їх лікування (гастрографія, гастроентерит, гастроентероколіт, гастроскоп); гемо- - частина слова, що означає «кров»; поширена в складі найменувань, які пов’язані 3 нею (гемодіаліз, гемокультура, гемосорбиія, гемостаз, гемотерапія, гемотрансфузія); ендо- перша частина складних слів, що означає «внутрішній»; уживається на позначення медичних і біологічних терміноодиниць (ендогенота, ендомітоз, ендоплазма, ендорадіозонд, ендотермія, ендотоксин); імуно- - компонент складних термінів, що стосуються імунітету (імунодепресія, імунодефіциит, імуноморфологія, імунопатологія, імунотерапія, імунохімія); кардіо- - перша частина складних слів, що означають «серце, кардіологія» (кардіовален, кардіодистрофія, кардіомегалія, кардіосклероз, кардіоспазм); остео- - уживається на позначення термінів, що пов’язані 3 кістками (остеодисплазія, остеодистрофія, остеосинтез, остеохондроз); стрепто- - вживається на позначення хвороб, спричинених стрептококом; найменування із зазначеним складником поширені й у ветеринарії (стрептодермія, стрептокароз, стрептококоз, стрептотрихоз); сфінктеро-- уживається на позначення термінологічних одиниць, пов'язаних зі сфінктером (сфінктерографія, сфінктерометрія, сфінктеропластика, сфінктеротомія); уретеро- - уживається на позначення термінів, пов'язаних із сечоводом (уретерографія, уретероектомія, уретеропатія, уретеропластика, уретеротомія); уретро- - складник термінослів, що пов’язані із сечівником (уретрограф, уретроплазія, уретропластика, уретроспазм, уретроцичстит); уро-- перша частина складних слів зі значенням «який стосується до сечі, сечостатевих органів» (уродинаміка, уродіазин, уроінфекція, уросепсис, уроскопія, уроцичстит).

Значна частина медичних термінів уживається 3 такими сталими постпозитивними компонентами: -пластика - другий компонент складного слова, що позначає хірургічний метод відновлення певних частин тіла або органів (абдомінопластика, аортопластика, артропластика, вальвулопластика, кератопластика); -терапія - друга частина складних слів, що означають спосіб, 
метод лікування на основі того, що назване першою частиною (аерозольтерапія, альготерапія, ампелотерапія, ароматерапія, бібліотерапія, вакцинотерапія, вібротерапія, галактотерапія, гальванотерапія, йоготерапія); -фобія - другий компонент складного слова, що вживається на позначення захворювання, пов'язаного зі страхом перед тим, що назване першою частиною (агорафобія, антропофобія, апіфобія, вакиинофобія, венерофобія, гіпнофобія, кардіофобія, клаустрофобія).

\section{Абревіація}

У складі галузевої термінології СУМ-20 не зафіксовано великої кількості абревіатур (оскільки інструкція передбачає введення до реєстру лише широковживаних скорочень), хоча в літературній мові «...спостерігається інтенсивне формування та закріплення у вжитку значного корпусу різноманітних складноскорочених слів» ${ }^{176}$. Як відомо, абревіація - це спосіб творення слів від усічених основ. Загалом учені за дериваційними ознаками поділяють абревіатури на три основних групи: часткові, ініціальні та комбіновані.

Ініціальні абревіатури, за результатами дослідження, становлять найбільшу групу термінів у СУМ-20 серед усіх складноскорочених слів. До них належать лексеми, що утворюються на основі початкових звуків чи літер слів складної номінації і є переважно: а) історичними термінами - КДБ (Комітет державної безпеки), КП(б)У (Комуністична партія більшовиків України), ОУН (Організація українських націоналістів), PCI (Робітничо-селянська інспекція), ФЗК (фабричнозаводський комітет), ЧОП (Частина особливого призначення для боротьби 3 бандитизмом); б) найменуваннями економічної галузі й фінансів - ВВП (валовий внутрішній продукт), ВНП (валовий національний продукт), $М В Ф$ (Міжнародний валютний фонд), ПДВ (податок на додану вартість) тощо.

Крім ініціальних, у СУМ-20 зафіксовано також чимало часткових абревіатур, характерною особливістю яких $є$ скорочення одного чи кількох компонентів твірної синтаксичної структури. Ці одиниці вживаються переважно на позначення історичної (бідком (комітет бідноти), волревком (волосний

${ }^{176}$ Стишов О. А. Українська лексика кінця XX століття (на матеріалі мови засобів масової інформації). К.: Вид. центр КНЛУ, 2003. С. 153. 
революційний комітет), військмор (військовий моряк), соимісто (соціалістичне місто) тощо) та військової лексики (артбаза (артилерійська база), артвогонь (артилерійський вогонь), артдивізіон (артилерійський дивізіон), артполк (артилерійський полк), військтехнік (військовий технік) тощо).

Комбінованих абревіатур, що належать до галузевої термінології, у Словнику української мови у 20-ти томах наразі не зафіксовано.

\subsubsection{2. Словотворення термінів-прикметників}

За нашими підрахунками, прикметникова термінологія в Словнику української мови у 20-ти томах становить близько 20 \% від усіх доданих галузевих термінів. Виникнення такої значної кількості ад’єктивів зумовлено активізацією можливостей мовної системи для передавання різноманітних ознак, якостей, властивостей у сфері термінотворення. Для прикметникової термінолексики найпродуктивнішим способом творення виявився морфологічний (афіксація та композиція).

\subsubsection{1. Суфіксальний спосіб творення термінів-прикметників}

Одним із провідних способів творення нових слів у мові завжди була й залишається суфіксальна деривація. Не становлять винятку й ад’єктиви-терміни в СУМ-20, що утворені за допомогою суфіксів на основі іменників та дієслів.

\section{Відіменникові прикметники}

Переважна частина прикметникових термінів - це віддіменникові одиниці.

Серед усіх суфіксів найвищу продуктивність має формант -н-, за допомогою якого утворено більшу частину термінів від простих і складних основ іменників (iз конкретною й абстрактною семантикою на позначення назв певних матеріалів, предметів, явищ, захворювань та інших понять) переважно іншомовного походження. Значна кількість зафіксованої термінолексики належить до: 1) лінгвістики (аблатив - аблативний, абруптив - абруптивний, аппозитив аппозитивний, афіксоїд - афіксоїдний, імперфект - імперфектний, консонант консонантний); 2) фізики, хімії (абсорбент - абсорбентний, аміди - амідний, 
антиоксидант - антиоксидантний, поліефір - поліефірний); 3) біологї (анатомії, ботаніки, зоології) (аддуктор - аддукторний, андроген - андрогенний, антиген антигенний, бентос - бентосний, гіпофіз - гіпофізний, галофіти - галофітний); 4) медицини, ветеринарії (акупунктура - акупунктурний, ангіна - ангінний, артроз - артрозний, вібріоз - вібріозний, гельмінт - гельмінтний); 5) техніки (бусоль - бусольний, ватерпас - ватерпасний, вібропрокат - вібропрокатний, гідроелеватор - гідроелеваторний, демонтаж - демонтажний, каупер кауперний).

На основі прикметникового суфікса -н- утворилися дериваційні форманти ичн- (-ічн-), -альн- (-ільн-), -арн- (-ярн), -ивн-. У СУМ-20 із цими суфіксами зафіксовано терміни, що є об’єктами хімії, фізики, медицини (актинічний, атомарний, біноміальний, вакцинальний, гранулярний, дигресійний). Поміж термінів, утворених від іменників за допомогою суфіксів -ичн- (-ічн-), -альн-, багато складних слів (переважно із запозиченими основами) на позначення фізичної та медичної термінології (аерогаммаспектрометричний, біогенетичний, вакуумметричний, геліогеофізичний, гіподермальний).

Продуктивністю в проаналізованому матеріалі відзначається суфікс -ов-, за допомогою якого утворено значну частину термінів-прикметників від іменникових основ іншомовного походження. Словотвірні типи прикметників із суфіксом -ов(-ев-) слугують для позначення відношень до певних матеріалів, предметів, речовин (це переважно терміни хімічної й фізичної царин): амоніаковий, ангідритовий, аргоновий, бензиловиц̆, галієвий, гліфталевий, кварковий. Крім названих вище галузей, деривати зі згаданим формантом уживаються для характеризування об'єктів науково-технічної царини (значна кількість термінів 3 інформатики й техніки): байтовий, габіоновий, діалоговий, батарейковий, маховиковий; суспільно-політичної та економічної термінології: акцептовий, блоковий, брендинговий, демпінговий, маркетинговий; біологічної лексики: ацидофріліновий, ботуліновий, ветиверієвий, джгутиковий, колагеновий, міцелелієвй.

Частина відіменникових прикметників, згідно з дослідженням, утворилася за допомогою суфікса -ськ-, що є складником одиниць, які виражають характерні 
ознаки певної особи, рідше предмета, часового періоду. Переважно це слова на позначення суспільної-історичної, релігійної та спеціальної термінології, серед якої значна частина складних слів (антропософський, бланкістський, дзенбуддистський, жсирондистський, металографський, надгігантський, намюрський).

Непродуктивним під час творення нових прикметників-термінів $є$ суфікс -ист- (бісмутистий, мастистий, сталистий).

\section{Віддісслівні прикметники}

У проаналізованому матеріалі виявлено, що віддієслівні ад’єктиви становлять кількісно невелику групу слів із двома типами суфіксів.

Велику активність у досліджуваних процесах виявили прикметникитерміни, утворені за допомогою суфіксів -альн (-ильн-), що є складниками дериватів, які вказують на призначення певного предмета. Такі одиниці поширені в технічній та спеціальній термінологіях. Це переважно префіксальні утворення: абсорбувальний, анестезувальний, відточувальний, відтягувальний, закріплювальний, заметувальний, затримувальний.

Як показали результати дослідження, суфікс -н- - малопродуктивний. Зафіксовано невелику кількість дериватів (переважно таких, що належать до кількох галузей знань) із префіксом за-: забивний, замірний, затримний. Згадані терміни вживаються $з$ аналогічним вищеописаним словотвірним значенням.

Термінологічна прикметникова лексика із суфіксами -івн-, -овн- зі значенням «який піддається впливу, здатний до чого-небудь» (автоматизовний, деформівний, інтегровний) поки що мало представлена в Словнику української мови у 20-ти томах, хоча останнім часом спостерігається досить активне вживання у фаховій літературі терміноодиниць із названими формантами.

\subsubsection{2. Префіксальний спосіб творення термінів-прикметників}

Нижчою продуктивністю, ніж суфіксальний, під час творення нових термінів-прикметників, зафіксованих у СУМ-20, відзначається префіксальний 
спосіб. Більшу частину таких дериватів становлять слова із запозиченими префіксами.

У проаналізованому матеріалі досить продуктивним для творення нових термінів-прикметників є власне український префікс не-, що вказує на відсутність того або протилежність тому, що названо твірною основою: невогнетривкий, негруповий, негубний, неізоморфний, нетермінологічний. Зазначений префікс уживається в складі терміноодиниць лінгвістики й інших галузей знань.

Як засвідчують матеріали СУМ-20, під час творення нових прикметників продуктивністю відзначаються іншомовні префікси анти-, ультра-, а малопродуктивним виявився префікс супер-.

Префікс анти- вказує на ознаку, наявність якої заперечує ознаку, виражену мотивувальним прикметником. Слова з названим афіксом, додані до реєстру 20томного словника, поширені переважно в медичній, фармацевтичній термінологіях, а також економічній, історичній, суспільно-політичній царинах: антигормональний, антидіуретичний, антисклеротичниц̆, антисоиіалістичний, антитоталітарний; супер- - указує на найвищу міру виявлення якоїсь ознаки стосовно інших ознак, названих мотивувальними прикметниками: суперважкий, суперсегментний; ультра- - вживається для вираження крайньої великої або крайньої малої безвідносної міри виявлення ознаки (поєднується і з простими, і зі складними основами українського й іншомовного походження): ультрависокочастотний, ультрадисперсний, ультрахолодний, ультрачервоний. Прикметники із цією морфемою поширені у фізичній і спеціальній термінологіях.

\subsubsection{3. Префіксально-суфіксальний спосіб творення термінів- прикметників}

Досить продуктивним під час творення нової прикметникової термінології в проаналізованому матеріалі є префіксально-суфіксальний спосіб. Тут доречно зауважити, що характерною особливістю прикметників із префіксами без-, від-, над-, поза-, проти-, які співвідносні з прийменниками, є те, що науковці їх розглядають по-різному: 1) як похідні одиниці від безпрефіксних ад’єктивів; 2) як 
слова, утворені префіксально-суфіксальним способом від іменників. У нашому дослідженні ці одиниці подано в складі другого способу.

Префіксально-суфіксальні прикметники-терміни виникають переважно на основі прийменниково-відмінкових форм іменників. Названий спосіб творення нових ад’єктивів відзначається більшою продуктивністю, ніж іменників. Префіксально-суфіксальні прикметникові деривати в СУМ-20 можна поєднати в такі основні словотвірні типи:

1. Прикметники 3 префіксом без- і суфіксами -н-, -ов-, -ев, що мають значення «який характеризується відсутністю того, що названо твірною основою»: безалкалоїдний, безарматурний, безбандажний, безвірусний, безгербіиидний, беззябровий, безлінійний, безопорний, безредукторний, безщілинний, беззябровий, безмуфтовий, безполицевий, безстиковий, безфондовий, безчовниковий. Більшість розглянутих дериватів поширена в технічній царині, проте велика кількість функціонує і в інших галузях, зокрема біології, хімії тощо.

2. Прикметники 3 префіксом від- і суфіксами -н-, -ов-, які означають «утворений від того, що позначено твірною іменниковою основою» (вживаються переважно на позначення лінгвістичних понять): відзайменниковий, відойконімний, відприйменниковий, відприкметниковий, відприслівниковий, відсубстантивний, відфраземний, відхоронімний, відчислівниковий.

3. Прикметники з префіксом проти- і суфіксами -н-, -ічн- (-ичн-), що мають значення «призначений для боротьби із чимсь», «скерований проти чогось» (поширені в медичній, фармацевтичній галузях): протиалергійний, протианемічний, протиаритмічний, противірусний, противісповий, протиенцеефалітний, протиінфекційний, протиспазматичний і т. ін.

4. Прикметники з префіксом поза- й суфіксами -н-, -ов- зі значенням «який міститься, перебуває або відбувається за межами того, що названо твірною основою»: позаблоковий, позамовний, позаринковий. Ад’єктиви цього малопродуктивного типу вживаються переважно в економічній i політичній царинах.

5. Малопродуктивний тип становлять прикметники 3 префіксом над- i суфіксами -н-, рідше -ов-, що мають значення «який міститься, розміщений над 
тим, що названо твірною основою»: надзябровий, надключичниц̆, надреберний, надсім'ядольний, надщзелеповий. Більшість подібних термінів належить до анатомії.

\subsubsection{4. Словотвір складних термінів-прикметників}

Проаналізована галузева лексика Словника української мови у 20-ти томах демонструє, що досить поширеними в іï реєстрі є також складні прикметникитерміни, основну групу яких становлять композити. Переважна частина цих слів утворена поєднанням основоскладання й суфіксації. Словотворення композитних прикметників-термінів зумовлене типом i семантикою базових синтагм та особливостями поєднання основ різних частин мови й певних афіксів.

Згідно з дослідженням, досить продуктивною є конструкція «прикметник + іменник + суфікси -ов- (-ев-), -н-», на основі якої утворено значну кількість спеціальних, технічних i біологічних термінів. Серед них зафіксовано найпоширеніші слова 3 першими частинами велико-, високо-, внутрішньокоротко-, широко- тощо: великоблоковий, великоклітинний, високовуглецевий, внутрішньоатомний, внутрішньом'язовий, внутрішньосуглобовий, внутрішньосуглобний, внутрішньосудинний, внутрішньоядерний, короткоструменевий, короткофокусний, ширококутний, широколінійний, широколопатевий. Також $є$ терміни з іншими складниками: очноямковиц̆, прямошаровий, рівноапостольний тощо.

Аналіз термінологічної лексики Словника української мови у 20-ти томах засвідчує, що на основі моделі «прикметник + прикметник» утворено в основному складні ад'єктиви, що пишуться через дефіс (причому дуже часто з усіченою першою основою). Серед них терміноодиниці, що належать до інформатики та фізики - аналого-цуифровий, електронно-цуифровий, лічильно-обчислювальний, магнітоелектричний; лінгвістичних понять - лексико-граматичний, лексикосемантичний; спеціальної термінології - селекційно-дослідний, селекційноплемінний; ботаніки - широкоовальний, широкоокруглий; військова термінологія: військово-інженерний, військово-космічний, військово-прикладний тощо. 
Під час творення прикметникової термінології, наявної в досліджуваному матеріалі, поширеною є конструкція «числівник + іменник + суфікси -н-, -ов(-ев)», де першою частиною складного слова виступають кількісні числівники: одно- (в основному на позначення біологічних понять) - однопелюстковий, односпоровий, однофазний, однояйцевий; дво- (двох-) (у хімічній, фізичній, технічній галузях) - двоводний (з двома молекулами води), двохвильовий, двохелектродний, двоччліндровий; чотири- (у спеціальній термінології) чотириатомний, чотирикулачковий, чотиритичинковий; п'яти- (більшість термінів належить до технічної галузі) - n'ятиелектродний, n'ятижильний, n'ятилопатевий, n'ятискладовий, n'ятитактний, n'ятицифрровий; шести(переважно в біології) - шестиногий, шестипелюстковий, шестиступеневий, шестициліндровий; семи- - семилатний (сім латок), семискладовий; багато- (є складником термінів фізичної, технічної галузей та літературознавства) багатоатомний, багатобітовий, багатостопний, багатострофний.

На основі моделі «іменник + прикметник (дієприкметник)» без суфіксації утворилися терміни переважно хімічної та технічної галузей: антибіотикостійкий, борорганічний, газонасичений, галогенопохідний, енергонасичений, знакопостійний тощо.

Серед одиниць, що утворені на основі конструкції «іменник + дієслово + суфікси -н-, -льн-, -ч-», у проаналізованому матеріалі зафіксовано такі, що вживаються переважно на позначення технічних і сільськогосподарських термінів: білковмісний, вантажозахватний, гайконарізний, каменезбиральний, картоплезбиральний, картоплесадильний, картоплесортувальний, сталевипускний.

У СУМ-20 за малопродуктивною моделлю «займенник + дієслово + суфікси -льн-, -н-» утворено невелику кількість термінів із першою частиною само-, що функціонують у технічній галузі: самоблокувальний, самовмикальний, самозакривний, самоналагоджувальний.

Не відзначається широким використанням конструкція «прислівник + дієслово + суфікси -н-, -к-». На їі основі утворилися слова 3 першою частиною 
важко-, що є технічними та хімічними термінами: важкоперероблюваний, важкорозчинний, важкотопкий.

Так само непродуктивною є модель «іменник + іменник + суфікси -ов- (-ев-), -н-», на основі якої утворилася незначна кількість термінів: бронхолегеневий, газопиловий, йодобромний.

\subsubsection{3. Словотворення термінів-дієслів}

Дієслівних термінів у СУМ-20 нараховується значно менше, ніж іменників та прикметників. Вони становлять 6 \% від усіх термінологічних одиниць, доданих у Словник української мови у 20-ти томах. Проте дієслівне словотворення відзначається більшою різноманітністю способів творення. Крім способів, що властиві всім частинам мови, є суто дієслівні способи деривації (постфіксальний, суфіксально-постфіксальний, префіксально-суфіксально-постфіксальний), на основі яких утворюється й термінологічна лексика в досліджуваному матеріалі.

\subsubsection{1. Суфіксальний спосіб творення термінів-дієслів}

Згідно з результатами дослідження, високу продуктивність під час творення нових дієслівних термінів має суфіксальний спосіб, за допомогою якого утворено нові слова на основі іменників і дієслів.

\section{Відіменникові дісслова}

Значну частину дієслівних термінів у СУМ-20 становлять одиниці із суфіксом -ува- (-юва-) іменникового походження, що означають дію, результат якої названий мотивувальним іменником. Вони поширені в різних галузях знань: акт - актувати, архів - архівувати, аудит - аудитувати, вакуум - вакуумувати, ескарп - ескарпувати, еталон - еталонувати, етап - етапувати, капсула капсулювати, квота - квотувати.

Меншу частину термінів становлять дієслова, що утворилися від іменників - назв речовин. Вони мають значення «діяти речовиною, що названа мотивувальною основою іменника». Уживаються в спеціальній та технічній термінологіях: бор - борувати, бром - бромувати, кадмій-кадміювати. 
За допомогою суфіксів -ізува- (-изува-) утворено частину дієслів зі значенням «досягати того або перетворюватися на те, на що вказує твірна основа»: алгоритм - алгоритмізувати, атом - атомізувати, параметр - параметризувати та із семантикою «забезпечувати чи охоплювати тим, на що вказує твірна основа»: алергія - алергізувати, алкоголь - алкоголізувати, аналогія аналогізувати. Такі терміноодиниці поширені в хімії, фізиці, інформатиці та інших галузях.

Проаналізований матеріал засвідчує, що суфікс -и- (-ї-), який виражає дію, стан або процес, малопродуктивний під час творення нових відіменникових дієслів-термінів. Зафіксовано всього кілька слів на позначення спеціальної й технічної лексики: зернь - зернити, міздря - міздрити, ртуть - ртутити, утор уторити.

\section{Дісслова, мотивовані дісслівними основами}

Префіксовані дієслова доконаного виду із суфіксом -ува- й утворені від них шляхом вторинної суфіксації дієслова із суфіксом -ов- + -ува- становлять велику частину галузевої термінології СУМ-20. Сюди належать слова 3 префіксами: від- уживається переважно в складі технічних, хімічних, будівельних термінів (відскановувати - відсканувати, відтитрувати - відтитровувати, відформатувати - відформатовувати, відфугувати - відфуговувати, відшпаклювати відшпакльовувати); за- - творяться терміни, що належать до кількох галузей знань; (зарегулювати - зарегульовувати, затюкувати - затюковувати, зафальцุювати - зафальцььовувати, заформувати - заформовувати, зацентрувати зацеентровувати, зашліхтувати - зашліхтовувати, заштабелювати - заштабельовувати, заштампувати - заштамповувати); про- - уживається в термінах на позначення спеціальних і технічних понять (провальц̧ювати - провальцุьовувати, пропазувати - пропазовувати); роз- - переважно в спеціальній термінології (розасигнувати - розасигновувати, розгерметизувати - розгерметизовувати, розелектризувати - розелектризовувати, розмалкувати - розмалковувати, розмаркувати - розмарковувати, розстикувати - розстиковувати).

Меншу кількість термінів становлять деривати, мотивовані дієсловами із суфіксом -и- (-ї-). Це дієслівна лексика на позначення в основному спеціальних та 
технічних понять із такими поширеними префіксами: за- (задубити - задублювати, замонолітити - замонолічувати, заростити - зарощувати, засвердлити - засвердлювати, заџиклити - заџиклювати, зашкалити - зашкалювати); роз- (розкиснити - розкиснювати, рознайтовити - рознайтовлювати, розпаузити - розпаужувати.

Деривати, мотивовані дієсловами доконаного виду із суфіксом -а- (-я-), становлять незначну кількість термінів, зафіксованих у СУМ-20. Це одиничні поняття, наприклад: зверстати - зверстувати, уваляти - увалювати.

\subsubsection{2. Префіксальний спосіб творення термінів-дієслів}

Префікс від-, зафіксований у термінах двадцятитомного словника, уживається зі значенням «припинення виконуваної дії». Поширений у номінаціях переважно технічної галузі: літографувати - відлітографувати, нікелювати віднікелювати, пасувати - відпасувати, тарувати - відтарувати, форматувати - відформатувати, хромувати - відхромувати, ипаклювати відшпаклювати, юстувати - від’юстувати.

Префікс за- позначає початок або кінець дії та слугує для творення переважно спеціальної термінології: дубити - задубити, екранувати заекранувати, клеймувати - заклеймувати, коксуватися - закоксуватися, тюкувати - затюкувати, фальцюювати - зафальцюювати, формувати заформувати, иліхтувати - зашліхтувати, итампувати - заштампувати.

Префікси 3- (зі-), с- означають завершення якоїсь дії: верстати зверстати, генерувати - згенерувати, сканувати - зісканувати, тушкуватися стушкуватися. Префікс не відзначається продуктивністю. Зафіксовані терміни належать до друкарства, інформатики, кулінарії.

Префікс про- в поєднанні 3 дієсловом недоконаного виду утворює нову дієслівну лексику, що має значення «спрямувати дію крізь що-небудь, пропустити один об'єкт крізь інший, проникнути в щось, закінчити виконувати або деформувати що-небудь»: вальц̧ювати - провальц̧ювати, деформувати - 
продеформувати, пазувати - пропазувати. Дієслова такого типу вживаються переважно в технічній галузі.

Префікс роз- відзначається високою продуктивністю під час творення нових дієслів-термінів у проаналізованому матеріалі. Цей афікс указує на розчленування якогось об'єкта 3 одночасним поширенням його де-небудь або на завершення якоїсь дії. Уживається в складі спеціальних термінів: асигнувати - розасигнувати, герметизувати - розгерметизувати, екранувати - розекранувати, електризувати - розелектризувати, маркувати - розмаркувати, найтовити - рознайтовити, стикувати - розстикувати, фокусувати - розфокусувати.

Запозичені префікси малопродуктивні під час творення нових дієслівних термінів. Активністю в СУМ-20 відзначаються всього дві морфеми - де- й ре-.

Дієслова 3 префіксом де- мають значення «виконати дію, протилежну дії мотивувального дієслова, анулювати дію, названу мотивувальним дієсловом». Поширені в різних галузях, а особливо в хімії, економіці: гідрувати - дегідрувати, ініцуіалізувати - деініц̧іалізувати, канонізувати - деканонізувати, капіталізувати - декапіталізувати, карбонізувати - декарбонізувати, хлорувати дехлорувати.

Префікс ре- вказує на зворотний напрям дії або на повторне їі завершення. Широко використовується для творення термінів економічної та фінансової галузей: інвестувати - реінвестувати, натуралізувати - ренатуралізувати, фінансувати - рефінансувати.

\subsubsection{3. Постфіксальний словотвір термінів-дієслів}

У реєстровому складі Словника української мови у 20-ти томах зафіксовано також значну кількість постфіксальних дієслів. Це одиниці зі значенням «піддаватися, підлягати дії чого-небудь», що вживаються для найменування: 1) спеціальної термінології (вакуумувати - вакуумуватися, відмучувати відмучуватися, експлікувати - експлікуватися, інвертувати - інвертуватися, параметризувати - параметризуватися); 2) технічних термінів (армувати армуватися, вальцювати - вальц̧юватися, накернувати - накернуватися); 
3) біологічних, хімічних і медичних термінів (аглютинувати - аглютинуватися, окисняти - окиснятися); 4) економічних та юридичних термінів (адоптувати адоптуватися, інвестувати - інвестуватися, ренатуралізувати - ренатуралізуватися).

Інші способи творення дієслів-термінів, зафіксованих у СУМ-20, поки що є малопродуктивними, тому в цій праці їх не розглядатимемо.

\subsubsection{4. Словотворення дієприкметників-термінів}

Основну частину нових термінів, зафіксованих у СУМ-20, становлять пасивні дієприкметники на -ний, що мотивовані дієсловами недоконаного й доконаного видів.

За допомогою суфікса -н- пасивні дієприкметники творяться від основи інфінітива, що закінчується на -а в складі суфіксів -ува-, -ва- чи закінчується суфіксом -а-.

На основі цієї моделі в СУМ-20 утворено найбільше слів (переважно 3 іншомовними основами) на позначення спеціальної термінології (агрегувати агрегований, гальванізувати - гальванізований, герметизувати - герметизований, декалькувати - декалькований, декантувати - декантований, ежектувати ежектований, забутувати - забутований, заформувати - заформований, імпрегнувати - імпрегнований, кадміювати - кадмійований, капотувати капотований, карбонізувати - карбонізований), а також терміноодиниць таких галузей: фізики, хімії (абсорбувати - абсорбований, азотувати - азотований, амонізувати - амонізований, деоінізувати - деоінізований, дехлорувати дехлорований, індукувати - індукований); техніки (відтарувати - відтарований, відфрезерувати - відфрезерований, зашунтувати - зашунтований, пропазувати пропазований); медицини (абортувати - абортований, денервувати - денервований, дефібринувати - дефібринований, іммобілізувати - іммобілізований, імплантувати - імплантований, катетеризувати - катетеризований).

Значну частину нових термінів становлять дієприкметники із суфіксом -ен-, що утворені від основи 1-ї особи однини теперішнього недоконаного виду або 
теперішньо-майбутнього часу дієслів доконаного виду, основа інфінітива яких закінчується на -и-. Подібні одиниці в СУМ-20 належать переважно до технічної галузі (відпалити - відпалений, намаслити - намаслений, напилити - напилений) та кількох терміносфер (грохотити - грохочений, забурити - забурений, забутити - забучений, затарити - затарений, заџиклити - зациклений, защеебенити - защеебенений).

\subsubsection{4. Словотворення термінів-прислівників}

Кількість термінів-прислівників порівняно 3 іншими частинами мови невелика. Вони становлять всього 0,8 \% від усієї доданої галузевої термінології. Також досліджувані прислівники не відзначаються різноманітністю способів творення. Майже всі вони з’явилися внаслідок суфіксації.

\subsubsection{1. Суфіксальний словотвір термінів-прислівників}

Серед прислівників, зафіксованих у СУМ-20, суфіксальним способом утворені відприкметникові терміни 3 формантом -о, що належать до різних галузей знань (алгоритмічний - алгоритмічно, антропоцентричний антропоцентрично, апогамний - апогамно, артикуляційний - артикуляційно, асинхронний - асинхронно, аспектологічний - аспектологічно, баріонний баріонно, білатеральний - білатерально, додатний - додатно, ендогенний ендогенно, ендоскопічний-ендоскопічно).

\subsection{3. Семантична деривація}

У творенні нових термінів досить активну участь бере також лексикосемантична, або семантична, деривація, суть якої «...полягає у використанні в ролі терміна готового слова, запозиченого з іншої лексичної підсистеми»» ${ }^{177}$.

Вивченню питання семантичної еволюції слів, як уже згадувалося раніше, приділяло увагу багато зарубіжних та українських дослідників. Семантичні інновації української мови перебувають в полі зору й сучасних мовознавців. Доречно також додати, що розвиток семантичної структури слів, трансформацію

177 Дячук Т. Семантичні зсуви (розширення і звуження) як способи поповнення складу соціально-економічної термінології. Українська термінологія $і$ сучасність: збірник наукових праць. К., 1998. С. 125 
їхніх значень, процеси термінологізації й детермінологізації розглянуто, зокрема, й на матеріалі СУМ-20 ${ }^{178}$.

Семантична трансформація загальновживаних слів, використання їх у статусі одиниць номінації спеціальної сфери відіграє значну роль у сучасному термінознавстві. «Для мови науки семантичний спосіб словотворення має особливий смисл, - зазначає В. Даниленко. - 3 його допомогою задовольняють дедалі більші потреби в нових термінах (семантичним перетворенням наявних у мові слів)» ${ }^{179}$. Семантичний спосіб був одним із перших прийомів утворення термінологічних найменувань. Перевагою термінів, утворених унаслідок семантичного переосмислення, є їхня стислість, влучність, дохідливість, саме ті якості, яких нерідко не вистачає довгим, незграбним «книжним» термінам ${ }^{180}$.

У досліджуваному матеріалі всі зафіксовані терміни - семантичні деривати, виникають на основі термінологізації загальновживаної лексики та вторинної термінологізації, або ретермінологізації (тобто перенесення готового терміна 3 однісї галузі в іншу з повним або частковим переосмисленням).

Відомо, що термінологізація - це семантичний процес, який пов'язаний із формуванням у загальновживаної лексеми ознак терміна. У наукових працях дослідники найчастіше звертають увагу на співвіднесеність таких слів зі спеціальним поняттям і належність до спеціальної сфери вживання (Б. Головін, Р. Кобрін та ін.). Отже, для творення термінологічних одиниць часто використовують слова загального вжитку. Ставши термінами, вони докорінно не

178 Див., напр.: Стратулат Н. В. Семантична неологізація як спосіб збагачення словникового складу української мови. Мовознавство. 2007. № 3. С. 69-77; Шевченко Л. Л., Томіленко Л. М. Мотиваційні основи та базові моделі семантичного процесу термінологізації (на матеріалі словника української мови в 20-ти томах). Мовознавство. 2010. № 1. С. 76-85.; Томіленко Л. М. Нове життя старих слів, або Семантичні зміни у структурі сучасної української лексики (на матеріалі Словника української мови у 20 -ти томах). Дивослово. 2016. № 6. С. 29 34; Томіленко Л. М. Розвиток семантичної структури українського дієслова (на матеріалі IV томів Словника української мови у 20 т.). Мандрівецฺь. 2016. № 1. С. 86-89.

179 Даниленко В. П. Русская терминология: Опыт лингвистического описания. М., 1977. C. 98 .

180 Лотте Д. С. Основы построения научно-технической терминологии. Москва: Изд-во AH CCCP. 1961. $158 \mathrm{c}$. 
змінюють свого значення, але набувають здатності передавати строго визначений науковий зміст.

Термінологічне значення, звичайно, продукується не будь-якому слову, а тому, яке вже реалізує свою номінативну функцію, позначаючи в мовній практиці поняття, що має асоціативну подібність із таким поняттям, яке потребує імені. Тобто утворений на основі загальновживаного слова термін $\epsilon$ семантично мотивованим знаком $^{181}$.

Аналізуючи нову термінологічну лексику в СУМ-20, що утворилася на основі семантичної деривації (термінологізації), застосовуватимемо компонентний (або семний) аналіз, що «...полягає в розщепленні значення слова на складові компоненти, які називаються семами, семантичними множниками i, зрідка, маркерами» $^{182}$.

Кожне значення слова, як відомо з мовознавчих праць, становить сукупність елементарних смислів (сем) - ієрархічно організовану структуру, у якій виділяється родовий смисл (архісема), видовий смисл (диференційна сема) та потенційні семи, що відбивають різні асоціації, побічні властивості об’єкта тощо.

«Сема, - зазначає В. М. Русанівський, - виражає певне відношення, що існує в об’єктивному світі: відношення до розміру, кольору, смаку, запаху, швидкості і т. ін. Сукупність таких сем створює семему. Семема не існує поза лексемою - пї матеріальним носієм, становлячи одне з $\dddot{11}$ значень» ${ }^{183}$.

Синонімом до слова «семема» $є$ термін «лексико-семантичний варіант», який увів у науковий обіг А. Смирницький.

Вивчення смислових перетворень за допомогою семного аналізу полягає в описі елементів певної лексеми: зіставлення вихідного й похідного значень, виявлення мінімальних складників семантики слова та їх значеннєвої спільності,

${ }^{181}$ Панько Т. І., Кочан I. М., Мацюк Г. П. Українське термінознавство. Львів: Світ, 1994. C. 205 .

182 Кочерган М. П. Загальне мовознавство: підручник. К.: Видавничий центр «Академія», 2003. C. 385.

183 Русанівський В. М. Структура лексичної і граматичної семантики. К.: Наук. думка, 1988. C. 29. 
визначення динаміки сем, причин та шляхів трансформації смислових компонентів слова.

Як продемонструвало дослідження, у Словнику української мови у 20-ти томах зафіксовано близько сотні нових термінів, що утворилися на основі термінологізації. Найактивніше поповнення новими одиницями спостерігається в таких галузях, як інформатика, спеціальна й технічна термінології, лінгвістика, менше термінологізованих слів зафіксовано в медицині та спорті, одиничні терміни функціонують у біології (ботаніка, зоологія), анатомії, геології, фізиці. У царині інформатики процес термінологізації виявляється найактивніше. Завдяки розвитку комп'ютерних технологій з'явилася велика кількість запозичених неологізмів, а також таких, які утворилися на основі семантичної деривації.

Насправді, як зауважують мовознавці, буває непросто визначити, чи відбувається повторне запозичення нового значення, чи воно розвивається на підставі семантики запозиченого слова, але вже в українській мові. Наприклад, О. Стишов підтверджує, що в низці випадків важко встановити, чи модифікація значення слова відбулася в мові-джерелі, чи в мові-реципієнті ${ }^{184}$. У нашому дослідженні всі подібні новотвори розглянуто в межах семантичної деривації.

Поява термінологічних значень у загальновживаних слів відбувається двома шляхами - це 1) збереження або модифікація архісеми та узагальнення, випадіння або введення нових диференційних сем; 2) зміна архісеми, актуалізація прихованої, функціональної та ін. диференційних сем i введення нових диференційних сем. Своєю чергою кожен із цих двох типів поєднує дериваційні моделі, на основі яких утворюються відповідні терміни. Поняття моделі може трактуватися в статичному або динамічному аспектах. У першому випадку моделлю буде абстрактний схематичний образ об'єкта (або його зовнішніх особливостей, або змісту, або одночасно того й того). У другому випадку - за динамічного підходу - термін моделювання вказує на утворення мовної одиниці. Тут також можлива різна інтерпретація: формальна модель показує, як одна

${ }^{184}$ Стишов О. А. Українська лексика кінця XX століття (на матеріалі мови засобів масової інформації). К.: Вид. центр КНЛУ, 2003. С. 213. 
структура виводиться з іншої, семантична - розкриває механізм утворення мовної одиниці ${ }^{185}$.

Таким чином, першим шляхом утворюються нові терміни за двома дериваційними моделями: звуження значення та семантичний зсув.

На основі звуження значення вихідної семеми з’явилися, наприклад, такі комп’ютерні терміни: адреса, адмініструвати, інтелектуалізувати; технічна та спеціальна термінологія: укріплення, ініціювати, увивати; лінгвістичні терміни: адресант, дескриптивний та ін. Лексико-семантична деривація цього типу відбувається за рахунок додавання до вихідного смислового змісту нових семантичних компонентів, які звужують, конкретизують семантику слова ${ }^{186}$.

Семантична структура слова адреса 3 первинним значенням 'позначення місця проживання чи перебування кого-небудь або місцезнаходження чого-небудь' розширилася за рахунок семеми 'унікальний ідентифікатор або номер, що присвоюється комп'ютерному пристрою або об'єкту комп’ютерної мережі для операцій із ними' (інформ.). Архісема 'позначення’ зберігається, конкретизується диференційна сема із широкою семантикою 'кого-небудь або чого-небудь' $\rightarrow$ ‘комп’ютерному пристрою або об’єкту комп'ютерної мережі', а також з’являється нова сема на позначення мети 'для операцій із ними'. Аналогічно утворюється друга семема слова адмініструвати 'керувати установою, організацією, підприємством і т. ін.; управляти' $\rightarrow$ 'здійснювати контроль та управління функціонуванням інформаційно-комп’ютерної системи, мережі' (інформ.). При цьому архісема 'здійснювати контроль, керувати' зберігається, відбувається зміна диференційної семи на позначення об’єкта керування: замість конкретизатора 'установа, організація, підприємство і т. ін.' з'являється 'інформаційнокомп’ютерна система, мережа', звужуючи значення слова (компонент 'і т. ін.' формував широку семантику). За такою ж моделлю утворено нове термінологічне значення слова інтелектуалізувати 'надавати технічним системам та процесам

${ }^{185}$ Кудрявцева Л. А. Моделирование динамики словарного состава языка. 2-е изд., испр. К.: ИПЦ «Киевский университет», 2004. С. 34.

${ }^{186}$ Кудрявцева Л. А. Моделирование динамики словарного состава языка. 2-е изд., испр. К.: ИПЦ «Киевский университет», 2004. С. 67. 
ознак, притаманних людському інтелекту' (інформ.) від вихідного - 'надавати чому-небудь інтелектуалізму; наситити що-небудь інтелектом'. Значення слова звужується завдяки появі семи, що називає конкретний об’єкт ('технічні системи та процеси'), на який спрямовується дія, замість семи із широким значенням 'чому-небудь'.

У лексемі укріплення від семеми 'оборонна споруда' шляхом збереження архісеми 'споруда' та приєднанням нових диференційних сем, що вказують на призначення предмета, утворюється нове значення слова, що переводить його до складу технічної термінології: 'споруди, призначені для закріплення, зміцнення, посилення чого-небудь' (техн.). Аналогічно з'являється нова семема дієслова ініціювати 'сприяти виникненню чи розвиткові чого-небудь' $\rightarrow$ 'започаткувати, викликати хімічну або ядерну реакцію шляхом зовнішнього впливу' (спец.). Архісема 'сприяти виникненню, започаткувати і т. ін.' зберігається, водночас конкретизується сема вихідного значення 'що-небудь' $\rightarrow$ 'хімічна або ядерна реакція'.

Особливістю лінгвістичної лексики, як і лексики деяких інших галузей, є те, що іï одиниці утворюються не тільки шляхом термінологізації загальновживаних слів (адресант, ускладнення, оглушувати), а й на основі ретермінологізації - від термінів інших наукових сфер (апікальний, дескриптивний).

Шляхом звуження значення, як уже було зазначено вище, утворилися лінгвістичні терміни адресант, дескриптивний. Семантичне наповнення слова aдpecaнm зі значенням 'той, хто адресує, надсилає кому-небудь листа, телеграму i т. ін.; відправник' розширилося за рахунок нової семеми 'автор, учасник акту усної чи писемної комунікації' (лінгв.). Новий лінгвістичний термін утворено таким способом: зберігається архісема 'особа', додано нову диференційну сему ‘усна комунікація’ (перше значення слова включало лише писемну комунікацію, на яку вказувала сема 'лист, телеграма і т. ін.'), що збільшило семантичний обсяг результативного значення. Завдяки звуженню значення на основі ретермінологізації розширилася семантична структура лексеми дескриптивний ‘описовий, наочний’ (сnеu.) $\rightarrow$ 'який описує синхронний стан мови за допомогою 
дистрибутивного методу’ (лінгв.). При цьому збережено архісему 'описовий, який описує' та додано диференційні семи, які формують термін лінгвістичної царини.

За цією ж моделлю утворився новий термін фізичної галузі - генерувати. У слові генерувати від семеми 'викликати появу, утворення чого-небудь; виробляти' 3'явилося нове термінологічне значення 'збуджувати (електричні коливання, сигнали іт. ін.); перетворювати різні види енергії на енергію електричних коливань’ (фіз.). Зберігається архісема ‘викликати появу, збуджувати’, звужується значення вихідної семеми шляхом конкретизації диференційної семи із широким семантичним обсягом 'що-небудь' $\rightarrow$ 'електричні коливання’.

Першим дериваційним шляхом на основі семантичного зсуву при збереженні або модифікації вихідної архісеми й зміні однієї чи декількох диференційних сем утворюються переважно нові терміни 3 інформатики. Наприклад, у слові версія 'один із варіантів викладу або тлумачення якогось факту, події, явища' $\rightarrow$ 'модифікований варіант комп’ютерного програмного або інформаційно-програмного продукту' (інформ.) зберігається архісема 'варіант', змінюється диференційна сема 'виклад або тлумачення якогось факту, події, явища' на 'комп'ютерний програмний або інформаційно-програмний продукт'. У слові пароль 'секретне умовлене слово, фраза, рідше якийсь умовний сигнал для розпізнання своїх людей на військовій службі або в конспіративних організаціях' $\rightarrow$ 'слово або сукупність знаків, що дозволяють користувачеві комп’ютера отримати доступ до даних і програм' (інформ.) відбувається збереження архісеми 'умовне слово, знак', зміна диференційних сем 'для розпізнання своїх людей на військовій службі або в конспіративних організаціях' $\rightarrow$ ‘що дозволяють користувачеві комп’ютера отримати доступ до даних і програм'.

На основі семантичного зсуву розширила свою семантику також лексема diacnopa 'значна частина народу (етнічної спільності), що перебуває поза країною його основного поселення' $\rightarrow$ 'частина рослини, що природно відокремлюється від неї і виконує функцію поширення та розмноження' (біол.), друге значення якої переміщує іiї до складу біологічної термінології. Під час утворення другої семеми 
відбувається модифікація архісеми 'частина народу' $\rightarrow$ 'частина рослини'. Водночас змінюються диференційні семи, які конкретизують семантику цих слів.

У лексемі ліга від первинного значення 'об'єднання окремих осіб, організацій, держав' утворилася нова семема 'об'єднання команд за рівнем майстерності' (спорт.). На основі збереження архісеми 'об'єднання' та зміни диференційних сем 'особи, організації, держави' $\rightarrow$ 'команди' з'явився новий термін спортивної галузі.

Значно більше нових галузевих термінів, зафіксованих у Словнику української мови у 20-ти томах, утворено другим шляхом (через зміну архісеми й різних модифікацій диференційних сем) за такими дериваційними моделями, як функціональне переосмислення, актуалізація асоціативної ознаки, актуалізація семи 'зовнішня ознака' та актуалізація прихованої семи.

Функціональне переосмислення полягає в зміні архісем вихідної семеми та актуалізації в семантичному дериваті функціональної семи вихідного значення, причому функціональний компонент значення може виражатися прихованою семою в структурі семантичного деривата.

На основі функціональної подібності з'явилися термінологічні значення, наприклад, у слів нагромаджувач (накопичувач), укладальник, які стали об'єктами технічної галузі й інформатики.

Від первинного значення лексеми нагромаджувач (накопичувач) 'той або те, що накопичує що-небудь’ шляхом переосмислення утворилося відразу два нових термінологічних значення 3 технічної царини та інформатики: 'пристрій, пристосування i т. ін., призначений для накопичення або запасу чого-небудь' (техн.) і 'пристрій або носій, призначений для зберігання даних із можливістю їх подальшого зчитування' (інформ.).

За аналогічною моделлю утворилася нова семема в слові укладальник 'той, хто укладає що-небудь; фахівець з укладання чого-небудь' $\rightarrow$ 'машина, механізм, призначений для укладання або вивантаження - монорельс та чотириколісний візок $з$ двома спеціальними захватами' (техн.). Відбулася заміна архісеми 'той, хто', ‘фахівець' на 'машина, механізм’, а також додано нову сему ‘вивантаження’. 
За асоціативними ознаками відбувається розширення семантичної структури таких слів, як команда, упаковувати, що поповнили галузь інформатики; стрес, відстежувати, розкреслювати, які належать до спеціальної та технічної термінології; ускладнення, апікальний (лінгвістична лексика) та атака, новоутворення, консервативний (медична галузь).

Асоціативне переосмислення полягає в зміні архісеми вихідного значення, актуалізації асоціативної ознаки та приєднанні нових диференційних сем. Варто зазначити, що асоціативні ознаки «...майже невловимі, асоціації часом непояснимі, вони апелюють до мовного чуття людини, іiі лінгвокраїнознавчої компетенції і т. ін.» ${ }^{187}$.

За цією моделлю розширилася семантична структура лексеми команда зі значеннями 'короткий усний наказ командира за встановленою формою' та 'чиєнебудь розпорядження, висловлене коротко, владно'. На основі асоціативного переосмислення з'являється семема 'елемент програми, що містить вказівку на певну операцію комп'ютера' (інформ.). Змінюється архісема 'наказ, розпорядження' $\rightarrow$ 'елемент програми' та на основі ознаки 'вказівка, наказ для виконання чогось' утворюється новий термін комп'ютерної сфери. При цьому архісема ‘вказівка, наказ’ переходить у диференційну сему нового термінологічного значення.

За асоціативними ознаками 'складати', ‘поєднувати’, що означають групувати що-небудь в одне місце, разом, з'являється друге термінологічне значення лексеми упаковувати 'складати багаж, речі і т. ін., збираючи їх разом' $\rightarrow$ ‘архівувати групу файлів в один файл-архів для економії місця на носії інформації' (інформ.).

Шляхом актуалізації асоціативної ознаки термінологізувалися також такі слова, як стрес, відстежувати, розкреслювати. Стрес 'стан організму, що виявляється у формі напруження або специфічних пристосувальних реакцій у відповідь на дію несприятливих зовнішніх або внутрішніх факторів' $\rightarrow$ 'зовнішня сила, що деформує об'єкт, на який вона спрямована' (техн.). Тут змінюється

${ }^{187}$ Кудрявцева Л. А. Моделирование динамики словарного состава языка. 2-е изд., испр. К.: ИПЦ «Киевский университет», 2004. С. 89. 
архісема 'стан організму’ $\rightarrow$ ‘зовнішня сила', актуалізується асоціативна ознака ‘щось руйнівне'. У першому значенні ознака руйнування виражена за допомогою сем 'напруження', 'несприятливі фактори', у другому - 'деформує об’єкт'. Лексема відстежувати 'здійснювати нагляд, контроль і т. ін. за чимсь; стежити'; 'з’ясувати, визначити, виявити' розширюється за рахунок семеми 'фіксувати, повторювати який-небудь процес, результати чого-небудь за допомогою спеціальної апаратури' (сnец.). Шляхом зміни архісеми 'стежити, виявляти' $\rightarrow$ ‘фіксувати, повторювати’ та появи на основі асоціацій, закріплених у нових диференційних семах (у цьому випадку прихованих) 'записувати, реєструвати щонебудь', утворився новий термін.

За асоціативною ознакою відбулося переосмислення слів ускладнення, апікальний та оглущувати, що поповнили реєстр лінгвістичної лексики. Від первинного значення слова ускладнення 'дія за знач. ускладни́ти і стан за знач. ускладни́тися’ (робити складнішим) утворилося два термінологічних значення медичної галузі (зафіксоване ще в СУМ-11) 'нове захворювання, яке виникло як наслідок іншої, попередньої хвороби’ та лінгвістики (з'явилося вже в СУМ-20) 'процес, унаслідок якого в межах морфемно нечленованих слів починають виділятися ті або інші морфеми' (лінгв.). В основі переосмислення лежить асоціативна ознака ‘ставати складнішим’ - від ‘складний - який має кілька частин або елементів’. Так, медичний термін означає, що внаслідок попередньої хвороби виникла ще одна, додаткова хвороба, а лінгвістичний - замість однієї морфеми виникло дві або кілька. За подібною моделлю з'являється нова семема в лексеми апікальний ‘верхівковий, спрямований угору’ (анат.) $\rightarrow$ ‘про приголосні звуки, утворювані кінчиком язика, напр., “д”, “т”" (лінгв.). Термінологічне значення утворюється на основі асоціативної ознаки 'вгорі, на кінці, на вершині чогонебудь'. На основі актуалізації асоціативної ознаки також утворилося нове термінологічне значення слова оглушувати 'шумом, гуркотом і т. ін. на деякий час притуплювати слух кому-небудь, позбавляти його гостроти' $\rightarrow$ 'вимовляти дзвінкий приголосний звук як глухий’ (лінгв.). Мотивувальна й мотивована семеми пов'язані семою 'оглушувати що-небудь', тобто зменшувати ясність, силу звучання. 
На основі актуалізації асоціативної ознаки утворюється також і медична лексика, зафіксована Словником української мови у 20-ти томах. Таким чином 3'явилася нова семема слова атака 'стрімкий напад війська на ворога; вирішальний етап наступу; рішучий швидкий наступ (у грі, суперечці і т. ін)' $\rightarrow$ 'гострий напад ревматизму' (мед.). При цьому архісема 'напад’ у значенні ‘наступ' змінюється новою архісемою 'напад’ у значенні 'приступ’; на основі ознак 'стрімкий', 'швидкий', 'різкий' з'являється нове значення, що переводить названу лексему до складу медичної галузі. За асоціацією утворюється й друге значення лексеми консервативний 'який спирається на традиції, зберігає старе, що надійно зарекомендувало себе'; 'який обстоює сталість у суспільному устрої та політиці' $\rightarrow$ 'який обходиться без оперативного втручання' (мед.). Друга семема поєднана 3 першою асоціативною ознакою 'старий, сталий, традиційний' Оскільки раніше в медицині не застосовували хірургічних методів, то безопераційне лікування отримало назву консервативного (тобто старого, традиційного).

За асоціативною ознакою 3'явилося також друге релігійне значення в лексеми занечищуватися 'ставати нечистим, забрудненим' $\rightarrow$ 'порушуючи релігійні норми, заповіді, ставати нечистим’. При цьому відбулася зміна архісеми ‘ставати нечистим, забрудненим’ у прямому значенні на 'ставати нечистим' (тобто таким, який виражає порушення узвичаєних норм поведінки; гріховним, аморальним) у переносному значенні. Якщо в першому випадку ознака нечистоти, забруднення стосується зовнішнього вигляду кого- або чого-небудь, то в новому значенні слова завдяки асоціативним зв'язкам вона слугує характеристикою людини.

На основі переосмислення з актуалізацією семи 'зовнішня ознака' з'явилися одиничні терміни технічної галузі, інформатики й анатомії. Так, за зовнішньою схожістю утворився технічний термін торпедо. Торпедо 'риба родини скатів, що має круглу форму й здатна утворювати електричні розряди' $\rightarrow$ 'автомобільна панель із приладами' (техн.). Відбулася зміна архісеми 'риба' $\rightarrow$ 'автомобільна панель'. У цьому випадку семантична ознака 'зовнішня подібність' не виражена експліцитно диференційною семою, нове значення з'явилося на основі 
імпліцитної семи. Тут варто зазначити, що переосмислення з актуалізацією семи 'зовнішня ознака' відбувається на основі зміни архісеми, приєднанні нових диференційних сем, актуалізації семи 'зовнішня форма', яка може бути або експліцитною, або імпліцитною.

За цією ж моделлю з'явилося нове термінологічне значення слова миша 'невелика тварина ряду гризунів, переважно сірого кольору, з гострою мордочкою і довгим тонким хвостом' $\rightarrow$ 'невеликий допоміжний пристрій для введення до комп’ютера інформації, переміщенням якого по поверхні (столу) контролюється положення курсора на моніторі; маніпулятор (у 4 знач.)’ (інформ.). Новий термін утворився шляхом зміни архісеми 'тварина' $\rightarrow$ 'пристрій' за конкретною ознакою - зовнішньою схожістю двох об’єктів.

За зовнішньою подібністю на основі зміни архісеми 'посудина' $\rightarrow$ 'частина органа' утворився новий термін анатомії від слова ампула 'герметично запаяна скляна посудина пляшкоподібної форми для зберігання в стерильному стані лікувальних та інших речовин' $\rightarrow$ 'розширена частина порожнистого трубкоподібного органа' (анат.).

Дослідження семантичних перетворень загальновживаних слів на матеріалі СУМ-20 продемонструвало, що поява нових термінів у сучасній українській мові активно відбувається через процес термінологізації. Формування нових термінологічних одиниць безпосередньо пов'язане 3 внутрішнім потенціалом лексичного значення, який продукує розширення семантичного обсягу слова. Як засвідчує проаналізований матеріал, на основі термінологізації найактивніше утворюються нові найменування, що належать до інформатики, техніки, спеціальної термінології, лінгвістики. Переважно це іменники, хоча зафіксовано й невелику кількість прикметників та дієслів, утворених цим способом. Переосмислення загальновживаних слів, їх перехід у терміни найчастіше відбувається на основі звуження значення, актуалізації асоціативної ознаки, функціональної подібності, «зовнішньої ознаки» тощо. 


\subsection{4. Запозичення термінів}

Запозичення лексики - це природний і необхідний процес мовного розвитку, зумовлений міжнародними зв'язками, контактами, взаємовідносинами народів та держав. Коло запозичень у кожну історичну епоху визначають суспільнополітичні, культурні та інші чинники, і цей процес відбувається разом із розвитком мови. Особливо активізувався він в епоху науково-технічного прогресу, коли завдяки розвитку науки й техніки в мову надходить велика кількість термінів, спеціальних слів і словосполучень тощо. Проблема запозичень завжди була в центрі уваги лінгвістів. В українському мовознавстві їй присвячено праці С. Соколової, Т. Кияка, Н. Клименко, С. Карпіловської, Л. Кислюк, П. Селігея, Г. Вознюк, О. Кочерги, Л. Козак та інших.

Запозичення $є$ одним із активних джерел творення терміносистем. «З огляду на інтернаціональний характер наукових знань в міру розвитку науки зростає обсяг галузевої термінолексики, яка вже не може живитися лише джерелом однієї національної мови» ${ }^{188}$. Причиною запозичень, на думку Л. Козак, $\epsilon$ екстралінгвальні та лінгвальні чинники, які взаємно зумовлені й пов'язані між собою. До зовнішніх причин належать територіальні, культурні, економічні, наукові контакти між українцями та іншими народами. Суто лінгвальними причинами є: а) потреба в поповненні, а то й створенні неіснуючої лексикотематичної групи разом із запозиченням відповідних понять; б) потреба в семантичному обмеженні питомого слова; в) усунення полісемії ${ }^{189}$.

Запозичення як засіб номінації сприяють певній економії мовних зусиль, оскільки для заповнення номінативних лакун, що виникли в лексичній системі, використовують одиниці чужої мови. У той же час утрата попередніх асоціативних зв'язків, які були в мові-джерелі, спричиняє втрату можливо властивої запозиченим словам мотивованості, що створює певні труднощі для

${ }^{188}$ Національні та інтернаціональні компоненти в сучасних терміносистемах / [Л. О. Симоненко, С. О. Соколова, І. В. Коропенко, М. П. Годована та ін.]; відп. ред. Л. О. Симоненко. К.: Наук. думка, 1993. С. 146.

${ }^{189}$ Козак Л. Запозичення як складова частина української технічної термінології. Украӥнська термінологія і сучасність: збірник наукових праць. К.: КНЕУ, 2007. Вип. VII. С. 63. 
розпізнавання їхнього смислу в процесі мовлення. Загалом запозичення як процес використання іншомовних елементів зумовлені лінгвістично суперечливою природою мовного знака: його довільністю як силою, що дозволяє запозичення, й недовільністю як чинником, що стоїть їм на перепоні. Українські мовознавці так описують особливості засвоєння мовою цієї категорії лексики: «...3 одного боку, кількість таких слів невпинно зростає. 3 іншого, у мові формуються захисні механізми реагування на запозичені слова. Багато 3 них, особливо ті, що називають нові поняття та нові реалії, швидко проходять стадію ізольованого існування в мові, формують численні кореневі гнізда. Вони включаються у процеси словотворення, стають твірними для словотвірних гнізд, отже збільшують свій словотворчий потенціал, заявляючи про своє право на існування в мові. Зростання словотвірної активності охоплює ті запозичені слова, що давно існують у мові, й ті, що приходять до неї упродовж кількох останніх десятиліть» ${ }^{190}$.

У Словнику української мови у 20 -ти томах запозичення становлять близько 19,8 \% від усіх доданих галузевих термінів, не враховуючи тих, які утворилися від іншомовних основ. Найбільше запозичених слів припадає на медичну, технічну царини, біологію, хімію, фізику. Приклади іншомовної лексики розглянуто нижче в межах галузей знань і тематичних груп.

Медична лексика: запозиченими лексемами є переважно назви захворювань людського організму (амок, абазія, варикоз, вітиліго, гематома, гепатит, гігрома, гінгівіт, глікемія, гранулема (гранульома), дисфазія, діарея, ектима, емпієма, енантема, енурез, ілеус, імпетиго, ірит тощо).

Біологічна лексика: назви речовин (вісцин, вітелін, гіалін, глобін, еластин, міозин та ін.); процеси та явища (гістоліз, гліколіз, мейоз); клітина (диплоїд, оперон, стеригма).

Хімічна лексика: назви речовин і сполук (азиди, вініл, вінол, гексан, гепарин, гептан, гідразин, гідрол, ізопрен, ідол, інозит, канцероген, ксиліт, меламін).

${ }^{190}$ Клименко Н. Ф., Карпіловська Є. А., Кислюк Л. П. Динамічні процеси в сучасному українському лексиконі. К.: Видавничий дім Дмитра Бураго, 2008. С. 189. 
Технічна лексика: назви пристроїв, приладів (ваєр, віндроза, габіон, дефібратор, дефібрер, думпер, екструдер, капсель та ін.).

Інформатика: назви на позначення комп'ютерної техніки (джойстик, дисплей, модем, сервер, чип); назви програм та мов програмування (бейсик, драйвер); назви одиниць вимірювання інформації (байт, біт).

Фізична лексика: назви одиниць вимірювання (генрі, гільберт, еман, зиверт, кельвін); назви речовин (гіперон, глюон, кварк).

Спеціальна термінологія: назви предметів - пристроїв, приладів і т. ін. (гексод, гігростат, гофр, дренчер, дунст); найменування величин, одиниць вимірювання, графічних зображеннь тощо (гідрокс, пуаз, солідус, тензор).

Геологічні терміни: назви мінералів (вавеліт, візеїт, вїкіт, вільсоніт, вітерит, галмей, енаргіт, епідот); поняття, пов'язані з будовою Землі (горст, грабен); назви процесів, явищ (діагенез); найменування періодів (архей).

Спортивна лексика: поняття, що стосуються спортивних ігор (дриблінг, офсайд); поняття, що стосуються боксу (клінч, свінг) та ін. терміни (ралі, серфінг, мейпінг).

Юридична термінологія: назви на позначення юридичних справ, дій, процесів іт.ін. (абандон, віндикація, делікт, делькредере, дефолт); особи (суб'єкти правовідносин): агнати, інсайдер.

Математична лексика: назви геометричних фігур, тіл (гексагон, гексаедр, фрактал); найменування функцій (екстремум, мажоранта).

Лінгвістичні терміни: поняття морфології (герундив); фонетики (акуm, умлауm); назви на позначення семантико-синтаксичних одиниць (рема, семема); поняття морфеміки (морф).

Музична термінологія: назви на позначення музичних звуків, творів, гри (баунс, глісандо, димінуендо, субіто, нонет); найменування музичних стилів, колективів (нонет, техно); назви музичних інструментів (бансурі, бансрі).

Фінансова лексика: назви фінансових дій, операцій, процесів (акорд, беса, велфер, лізинг).

Історична термінологія: назви осіб (адаміти, бут, веліт, вілан, вілік), організацій (абвер, буле). 
Економічні терміни: назви на позначення угод, розпоряджень (делівері, фоб); найменування установ (холдинг); а також інших понять - дефлятор, маркетинг.

Як бачимо з проаналізованого матеріалу, запозичення - один з основних шляхів поповнення термінофонду нашої мови фаховими термінами. Найбільше іншомовної лексики, зафіксованої в СУМ-20, нараховує медична, біологічна, хімічна, геологічна, технічна терміносистеми. Інші галузі знань мають у своєму складі менше запозичених слів.

Аналіз нової термінологічної лексики, що міститься в реєстрі Словника української мови у 20-ти томах, дозволяє спостерігати найактивніші лексикодериваційні мовні процеси, дослідження яких сприяє формуванню уявлення про роль та місце термінів у мові. Галузева термінологія утворюється на основі тих самих способів і типів, що й слова літературної мови, відмінність полягає лише в продуктивності тієї або тієї словотвірної моделі чи формантів.

Отже, термінологічна лексика $є$ важливим складником лексичної системи української мови. Вона поширена в реєстрах великих тлумачних словників. У СУМ-20 порівняно із СУМ-11 спостерігається суттєве збільшення кількості термінів, що пов'язано з науково-технічною й соціальною революціями, які відбулися в період між створенням цих праць. Зазначене зростання є свідченням процесів інтелектуалізації, демократизації та глобалізації, що характерні для сучасного світу й України зокрема.

Здійснений аналіз фахової термінології в реєстрі Словника української мови у 20-ти томах формує певний лексикографічний стандарт для іï фіксації в тлумачній лексикографії та відкриває нові можливості для створення термінологічних і термінографічних праць, узгоджених із загальною лексикограматичною й лексико-семантичною системою сучасної української мови. Проведене дослідження, на нашу думку, визначає й певний напрям для створення комплексної, універсальної комп’ютерної системи української термінографії. 


\section{ЛITEPATУPA}

1. Алексеев Д. И. Сокращенные слова в русском языке. Саратов : Изд-во Саратов. ун-та, 1979. $328 \mathrm{c}$.

2. Балог В. О. Галузева лексика в Словнику української мови в 11-ти томах (1970-1980 pp.) (семантичний та стилістичний аспекти): автореф. дис. на здобуття наук. ступеня канд. філол. наук: спец. 10.02.01 «Українська мова». К., 2003. 16 с.

3. Біблія, або книги Святого Письма Старого і Нового Заповіту із мови давньоєврейської і грецької на українську наново перекладена. К.: Укр. біблійне тов., 2002. 1165 с.

4. Бодуэн де Куртенэ И. А. Избранные труды по общему языкознанию. М.: Изд-во АН CCCP, 1963. Т. 1. 384 с.; Т. 2. 391 с.

5. Боярова Л. Термінологічна лексика в загальномовному тлумачному словнику. Лексикографічний бюлетень. К., 2008. Вип. 17. С. 13-24.

6. Брагина А. А. Неологизмы в русском языке. М. : Просвещение, 1973. 223 с.

7. Будагов Р. А. Человек и его язык. М.: Изд-во Моск. ун-та, 1976. 429 с.

8. Валгина Н. С. Активные процессы в современном русском языке: учеб. пособие [для студентов вузов]. М., 2003. 303 с.

9. Веремчук О. Стилістична транспозиція термінологічної лексики в сучасній українській мові (кодифікаційний аспект). Рівне, 2010. 224 с.

10. Виноградов В. В. Вопросы современного русского словообразования // Русский язык в школе. 1951. № 2. С. 1-10.

11. Виноградов В.В.Русский язык. Грамматическое изучение о слове. М. : Высш. шк., $1972.614 \mathrm{c}$.

12. Виноградов В. В. Стилистический аспект русского словообразования. М. : Наука, 1984. 184 c.

13. Винокур Г. О. Маяковский - новатор язика. М. : Сов. писатель, 1943. 136 с.

14. Винокур Г. О. О некоторых явлениях словообразования в русской технической терминологии. Труды МИФЛИ: Сборник статей по языковедению. М., 1939. Т. V. С. 3-54.

15. Волков С. С. Неологизмы и внутренние стимулы языкового развития / С. С. Волков, Е. В. Сенько // Новые слова и словари новых слов: сб. статей / [отв. ред. Н.З. Котелова]. Л. : Наука, 1982. С. 43-56.

16. Гак В. Г. Языковые преобразования. М. : Языки русской культуры, 1998. 768 с.

17. Голованова Е. А. Об одном типе препозитивных единиц в современном русском языке // Развитие современного русского языка. М., 1986. 345 с.

18. Городенська К. Г. Нові запозичення і новотвори на тлі фонетичної та словотвірної підсистем української літературної мови. Українська термінологія $і$ сучасність: збірник наукових праць. К.: КНЕУ, 2009. Вип. VIII. С. 3-9.

19. Горпинич В.О.Сучасна українська мова. Морфеміка. Словотвір. Морфологія. К. : Вища шк., 1999. 207 с.

20. Гринев С. В. Введение в терминоведение. М.: Московский лицей, 1993. 309 с.

21. Гулыга Е. В. Новое и старое в лексике и грамматике немецкого языка / Е. В. Гулыга, Е. В. Розен. Л., 1997. 215 с.

22. Гумбольдт В. фон. Избранные труды по языкознанию / Пер. с нем. Г. В. Рамишвили. М. : Прогресс, 1984. 397 с.

23. Даниленко В. П. Русская терминология: Опыт лингвистического описания. М., 1977. $245 \mathrm{c}$.

24. Дешериев Ю. Д. Закономерности развития и взаимодействия языков в советском обществе. М. : Наука, 1966. 402 с.

25. Дешериев Ю. Д. Проблема функционального развития языков и задачи социолингвистики // Язык и общество / [под ред. Ф.П.Филина]. М. : Наука, 1968. С. 55-61. 
26. Дячук Т. Семантичні зсуви (розширення і звуження) як способи поповнення складу соціально-економічної термінології. Украӥнська термінологія і сучасність: збірник наукових праць. К., 1998. С. 125-128.

27. Ермакова О. П. Вторичная номинация в семантической структуре многозначных производных слов // Способы номинации в современном русском языке / [отв. ред. Д. Н. Шмелев]. М. : Наука, 1982. С. 109-123.

28. Жайворонок В. В. Лексична підсистема мови i значення мовних одиниць // Мовознавство. 1999. № 6. С. 32-46.

29. Журавлев В. К. Внешние и внутренние факторы языковой эволюции. М. : Наука, 1989. $328 \mathrm{c.}$

30. Журавлева Т. А. Особенности терминологической номинации. Донецк: Донбасс, 1998. $252 \mathrm{c}$.

31. Зацний Ю. А. Розвиток словникового складу англійської мови в 80-ті роки ХХ ст.: дис. ... доктора філол. наук: 10.02.04 / Зацний Юрій Антонович. Запоріжжя, 1999. 403 с.

32. Земская Е. А. Активные процессы современного словопроизводства // Русский язык конца XX столетия (1985-1995) / [под ред. Е.А.Земской] [2-е изд.]. М. : Языки русской культуры, 2000. С. 90-141.

33. Земская Е. А. Словообразование как деятельность. М. : Наука, 1992. 220 с.

34. Ільїн В. С. Префікси в сучасній українській мові. К., 1953. 165 с.

35. Карцевский С. И. Об ассиметрическом дуализме лингвистического знака // Звегинцев В. А. История языкознания XIX-XX веков в очерках и извлечениях. М.: Учпедгиз, 1965. Ч. 2. С. $85-90$.

36. Кислюк Л. П. Словотвірна номінація в сучасній українській мові: система - узус ідіолект: дис... доктора філогічних наук зі спец. 10.02.01 «Українська мова». К., 2018. 616 с.

37. Кияк Т. Р. Лингвистические аспекты терминоведения: учеб. пособие. К.: УМК ВО, 1989. 312 c.

38. Клименко Н. Ф., Карпіловська Є. А., Кислюк Л. П. Динамічні процеси в сучасному українському лексиконі. К.: Видавничий дім Дмитра Бураго, 2008. 335 с.

39. Клименко Н. Ф. Як народжується слово. К. : Рад. школа, 1991. 287 с.

40. Ковалик I. І. Вчення про словотвір I. І. Ковалик. Львів : Вид-во Львів. ун-ту, 1961. Вип. $2.54 \mathrm{c.}$

41. Козак Л. Запозичення як складова частина української технічної термінології. Українська термінологія і сучасність: збірник наукових праць. К.: КНЕУ, 2007. Вип. VII. C. 63-65.

42. Коломієць В. Т. Розвиток лексики слов’янських мов у післявоєнний період. К. : Наук. думка, 1973. 302 с.

43. Кочерган М. П. Загальне мовознавство: підручник. К.: Видавничий центр «Академія», 2003. 464 с.

44. Кубрякова Е. С. Что такое словообразование. М.: Наука, 1965. 78 с.

45. Кудрявцева Л. А. Моделирование динамики словарного состава языка. 2-е изд., испр. К.: ИПЦ «Киевский университет», 2004. 208 с.

46. Кузнецова Э. В. Лексикология русского языка: учеб. пособие для филол. фак. ун-тов. 2-е изд., испр. и доп. М.: Высш. шк., 1989. 216 с.

47. Кутина Л. Л. Термин в филологических словарях (к антитезе: энциклопедическое филологическое). Проблематика определений терминов в словарях разных типов. Л.: Наука, 1976. C. 21-27.

48. Левицький А. С. Актуальні проблеми розвитку неології (на матеріалі англійської мови). Вісник Житомирського держ. ун-ту імені Івана Франка. Житомир: Ред.-вид. від Житомирського держ. ун-ту імені Івана Франка. Вип. 23. 2005. С. 16-22.

49. Лексика русского литературного языка XIX начала XX века / [отв. ред. Ф. П. Филин]. М.: Наука, 1981. 357 с.

50. Лексика современного русского литературного языка / [под ред. М. В. Панова]. М. : Наука, 1968. 185 с. 
51. Лепеха Т. В. Лексико-семантичні та словотвірно-структурні особливості судовомедичної термінології: дис... канд. філол. наук: 10.02.01 «Українська мова», 2000. 201 с.

52. Лисиченко Л.А. Лексикологія сучасної української мови. Семантична структура слова. Харків: Харк. ун-т, 1977. 114 с.

53. Лотте Д. С. Основы построения научно-технической терминологии. М. : Изд-во АН СССР. $1961.76 \mathrm{c}$.

54. Мацько Л. І. Стилістика української мови: підруч. [для студ. філол. спец. вищ. навч. закл.] / Л. І. Мацько, О. М. Сидоренко, О. М. Мацько; [ред. Л.І. Мацько]. [2-е вид.]. К. : Вища шк., 2005. 262 c.

55. Мацько Л. Українська мова в кінці ХХ ст. (зміни в лексиці). Дивослово. 2000. № 4. С. 15-20.

56. Мельничук О. С. Розвиток мови як реальної системи. Мовознавство. 1981. № 2. C. 22-34.

57. Мельничук О.С. Розвиток мови як суспільне явище і як предмет сучасного мовознавства. Мовознавство. 1991. № 3. С. 3-11.

58. Мельчук И. А. О внутренних флексиях в индоевропейских и семитских языках. Вопросы языкознания. 1963. № 4. С. 32-54.

59. Муромцева О.Г. Про деякі активні процеси в словниковому складі української літературної мови кінця 80-90-х років XX ст. Українська мова: з минулого в майбутне : матеріали наук. конференції. К., 1998. С. 115-116.

60. Муромцева О. Г. Розвиток лексики української літературної мови в другій половині XIX - на поч. XX ст. Харків : Вища шк., 1985. 152 с.

61. Науково-технічний прогрес і мова / відп. ред. В. М. Русанівський. К.: Наук. думка, 1978. $196 \mathrm{c}$.

62. Національні та інтернаціональні компоненти в сучасних терміносистемах / [Л. О. Симоненко, С. О. Соколова, I. В. Коропенко, М. П. Годована та ін.]; відп. ред. Л. О. Симоненко. К.: Наук. думка, 1993. 238 с.

63. Нікітіна Ф. О. Семантичні та словотворчі проблеми сучасної термінології. К.: Вища школа, 1978. $31 \mathrm{c.}$

64. Ніколаєва А. О. Структурно-семантична характеристика термінології програмування, комп'ютерних мереж та захисту інформації: дис... канд. філол. наук: 10.02.01 «Українська мова». Харків, 2002. 190 с.

65. Ожегов С. И. О трех типах толковых словарей современного русского языка. Вопросы языкознания. 1952. № 2. С. 85-103.

66. Паламарчук Л. С. Терминологическая лексика в общеязыковом (филологическом) словаре. Проблематика определений терминов в словарях разных типов. Л.: Наука, 1976. C. 250-257.

67. Паламарчук Л. С. Тлумачний словник української мови в колі слов'янських словників цього типу: доповідь на VII Міжнародному з'їзді славістів (Варшава, серпень 1973 р.). К.: Наук. думка, 1973. С. 20 с.

68. Панько Т. І., Кочан І. М., Мацюк Г. П. Українське термінознавство. Львів: Світ, 1994. $216 \mathrm{c}$.

69. Перерва В. М. Перерождаются ли термины в общем употреблении. Современная русская лексикография. Л. : Наука, 1980-1981. С. 89-96.

70. Плотников Б. А. О форме и содержании в языке. Минск : Высш. шк., 1989. 256 с.

71. Развитие русского языка: сб. статей Л. П. Крысина. М., 1986. 412 с.

72. Реформатский А. А. Мысли о терминологии. Современные проблемы русской терминологии. М., 1986. С. 163-198.

73. Роль человеческого фактора в языке. Язык и картина мира / [Б. А. Серебренников, Е. С. Кубрякова. В. И. Постовалова и др.] М. : Наука, 1988. 216 с.

74. Русанівський В. М. Життя слова / В. М. Русанівський, С. Я. Срмоленко. К. : Вища шк. при КДУ, 1978. 191 с.

75. Русанівський В. М. Мова і суспільний процес // Мова і процеси суспільного розвитку / [ред. В.М. Русанівський]. К. : Наук. думка, 1980. С. 17-23. 
76. Русанівський В. М. Структура лексичної і граматичної семантики. К.: Наук. думка, 1988. $240 \mathrm{c}$.

77. Русский язык конца XX столетия (1985-1995) / [под ред. Е.А. Земской]. [2-е изд]. М. : Языки русской культуры, 2000. 480 с.

78. Семчинський С. В. Загальне мовознавство / [2-ге вид.]. К. : АТ “ОКО”, 1996. 416 с.

79. Сепир Э. Язык. Введение в изучение речи / Пер. с англ. А. М. Сухотина. М.-Л. : Соцекгиз, 1934. 223 с.

80. Симоненко Л. О. Термін у загальномовних словниках. Украӥнська $і$ слов'янська тлумачна та перекладна лексикографія. Леонідові Сидоровичу Паламарчукові. К.: КММ, 2013. C. 218-225.

81. Склад і структура термінологічної лексики української мови / [А. В. Крижанівська, Л. О. Симоненко, Т. І. Панько та ін.]; за ред. А. В. Крижанівської. К.: Наук. думка. 1984. 196 с.

82. Словотвір сучасної української літературної мови / [за ред. М.А. Жовтобрюха]. К. : Наук. думка, 1979. 405 с.

83. Современный русский язык. Словообразование / [за ред. Е. А. Земской]. М. : Просвещение. 1986. 342 с.

84. Соколова О. С. Префіксальний словотвір дієслів у сучасній українській мові. К. : Наук. думка, 2003. 283 с.

85. Сорокин Ю. С. Развитие словарного состава русского литературного языка 30-90 годы ХІХ века. М.; Л. : Наука, 1965. 564 с.

85. Соссюр Ф. де. Курс загальної лінгвістики. К. : Основи, 1998. 324 с.

86. Сороколетов Ф. П. Лексико-семантическая система и словарь национального языка // Современность и словари / [ред. Ф. П. Филин и Ф. П. Сороколетов: сб. статей]. Л. : Наука, 1978. $179 \mathrm{c}$.

87. Стишов О. А. Українська лексика кінця XX століття (на матеріалі мови засобів масової інформації). К.: Вид. центр КНЛУ, 2003. 388 с.

88. Стратулат Н. В. Семантична неологізація як спосіб збагачення словникового складу української мови. Мовознавство. 2007. № 3. С. 69-77.

89. Сучасна українська літературна мова : підруч. [для студ. філол. спец. вузів] / [за ред. А.П.Грищенка. Л. І. Мацько, М. Я. Плющ та ін.]. [2-е вид. перероб. і доп.]. К. : Вища шк., 1997. $493 \mathrm{c}$.

90. Тараненко А. А. Языковая семантика в ее динамических аспектах. К.: Наук. думка, 1989. $256 \mathrm{c}$.

91. Тараненко О. О. Актуалізовані моделі в системі словотворення сучасної української мови (кінець XX - початок XXI ст.). К.: Видавн. дім Д. Бураго, 2015. 248 с.

92. Тихонов А. Н. Словообразовательный словарь русского языка. М. : Русский язык, 1990. $465 \mathrm{c}$.

93. Томіленко Л. М. Термінологічна лексика в сучасній тлумачній лексикографії української літературної мови. Івано-Франківськ: Фоліант. 160 с.

94. Томіленко Л. М. Нове життя старих слів, або Семантичні зміни у структурі сучасної української лексики (на матеріалі Словника української мови у 20-ти томах). Дивослово. 2016. № 6. C. 29-34

95. Томіленко Л. М. Розвиток семантичної структури українського дієслова (на матеріалі I-V томів Словника української мови у 20 т.). Мандрівещь. 2016. № 1. С. 86-89.

96. Українська мова: Енциклопедія / [редкол.: О. О. Тараненко, М. П. Зяблюк та ін.]. К. : Укр. Енцикл., 2004. 821 с.

97. Уфимцева А. А. Опыт изучения лексики как системы (на материале английского языка). М. : Изд-во Академии наук СССР, 1962. 287 с.

98. Филин Ф. П. Истоки и судьбы русского литературного языка. М.: Наука, 1981. 326 с.

99. Чернобай Л. И. О взаимодействии терминологического и общелитературного словообразования (на материале неологизмов французского языка). Термины в языке и речи: межвуз. сб. Горький: ГГУ, 1985. С. 52-56. 
100. Шанский Н. М. Лексикология современного русского языка: пособ. для студ. пед. ин-тов. [2-е узд]. М. : Просвещение, 1972.327 с.

101. Шанский Н. М. Основы словообразовательного анализа. М. : Учпедгиз, 1953. 366 с.

102. Шанский Н. М. Очерки по русскому словообразованию и лексикологии. М. : ГУППИ, 1954. $310 \mathrm{c.}$

103. Шведова Н. Ю. Предисловие к двадцать первому изданию // С. И. Ожегов. Словарь русского языка. 21 изд. М., 1991. С. 6-11.

104. Шевченко Л. Л., Т Томіленко Л. М. Мотиваційні основи та базові моделі семантичного процесу термінологізації (на матеріалі словника української мови в 20-ти томах). Мовознавство. 2010. № 1. С. 76-85.

105. Широков В. А., Симоненко Л. О. Досягнення й розвиток українського термінознавства від 90-х років XX ст. - початку XXI ст. Актуальні проблеми романо-германської філології та прикладної лінгвістики. Чернівці, 2014. № 2. С. 239-248.

106. Широков В. А. Елементи лексикографії. К.: Довіра, 2005. 304 с.

107. Широков В. А. Інформаційна теорія лексикографічних систем. К.: Довіра, 1998. 331 с.

108. Широков В. А. Комп'ютерна лексикографія. К.: Наук. думка, 2011. 352 с.

109. Широков В. А. Феноменологія лексикографічних систем. К.: Наук. думка, 2004. 328 с.

110. Шмелев Д. Н. О некоторых тенденциях развития современной русской лексики // Развитие лексики современного русского языка / [под ред. Е. А. Земской и Д. Н. Шмелева]. М.: Наука, 1965. 134 с.

111. Шмелев Д. Н. Очерки по семасиологии русского языка. М.: Просвещение, 1964. 244 с.

112. Шмелев Д. Н. Современный русский язык. Лексика. М. : Просвещение, 1977. 335 с.

113. Щерба Л. В. Опыт общей теории лексикографии // Известия Академии наук СССР, Отделение литературы и языка. М., 1940. № 3. С. 89 -117.

114. Щерба Л. В. О словарях живого литературного языка. Современная русская лексикология. М.: Наука, 1966. С. 74-77.

115. Щерба Л. В. Что такое словообразование (тезисы доклада). Вопр. языкознания. 1962. № 2.

116. Языковая номинация. Виды наименований / [отв. ред.: Б. А. Серебренников, А. А. Уфимцева]. М. : Наука, 1977. 359 с. 
ЛІНГВІСТИЧНО-ІНФОРМАЦІЙНІ СТУДІї

ПРАЦІ УКРАЇНСЬКОГО МОВНО-ІНФОРМАЦЙНОГО ФОНДУ НАН УКРАЇНИ

У П'ЯТИ ТОМАХ

За загальною редакцією $B$. А. Широкова

TOM III

ТЛУМАЧНА ЛЕКСИКОГРАФІЯ

КНИГА 3

ДИНАМІКА ЛЕКСИКО-СЕМАНТИЧНОГО СКЛАДУ СЛОВНИКА УКРАЇНСЬКОЇ МОВИ У ДВАДЦЯТИ ТОМАХ

Редактор Н. В. Щербакова

\begin{abstract}
Видавець:
УКРАЇНСЬКИЙ МОВНО-ІНФОРМАЦІЙНИЙ ФОНД

НАЦІОНАЛЬНОЇ АКАДЕМІЇ НАУК УКРАЇНИ

03039, м. Київ, Голосіївський проспект, буд. 3

Свідоцтво про внесення суб' єкта видавничої справи

до державного реєстру видавців,

виготовників і розповсюджувачів видавничої продукції

серія ДК № 4652
\end{abstract}

Підписано до друку 26.10.2018. Формат 70х100 1/16

Ум. друк. арк. 13,9. Обл.-вид. арк. 13,7.

Тираж 300

Виготовлювач:

«Видавництво Ліра-К»

Свідоцтво № 3981, серія ДК

031156 м. Київ, вул. Ф. Пушиної, 27, оф. 20-22

Тел./факс (044) 247-93-37; 228-91-12

Сайт: lira-k.com.ua

Редакція: zv_lira@ukr.net 